\title{
Tissue Vascularization with Endothelial-like Mesenchymal Stromal Cells
}

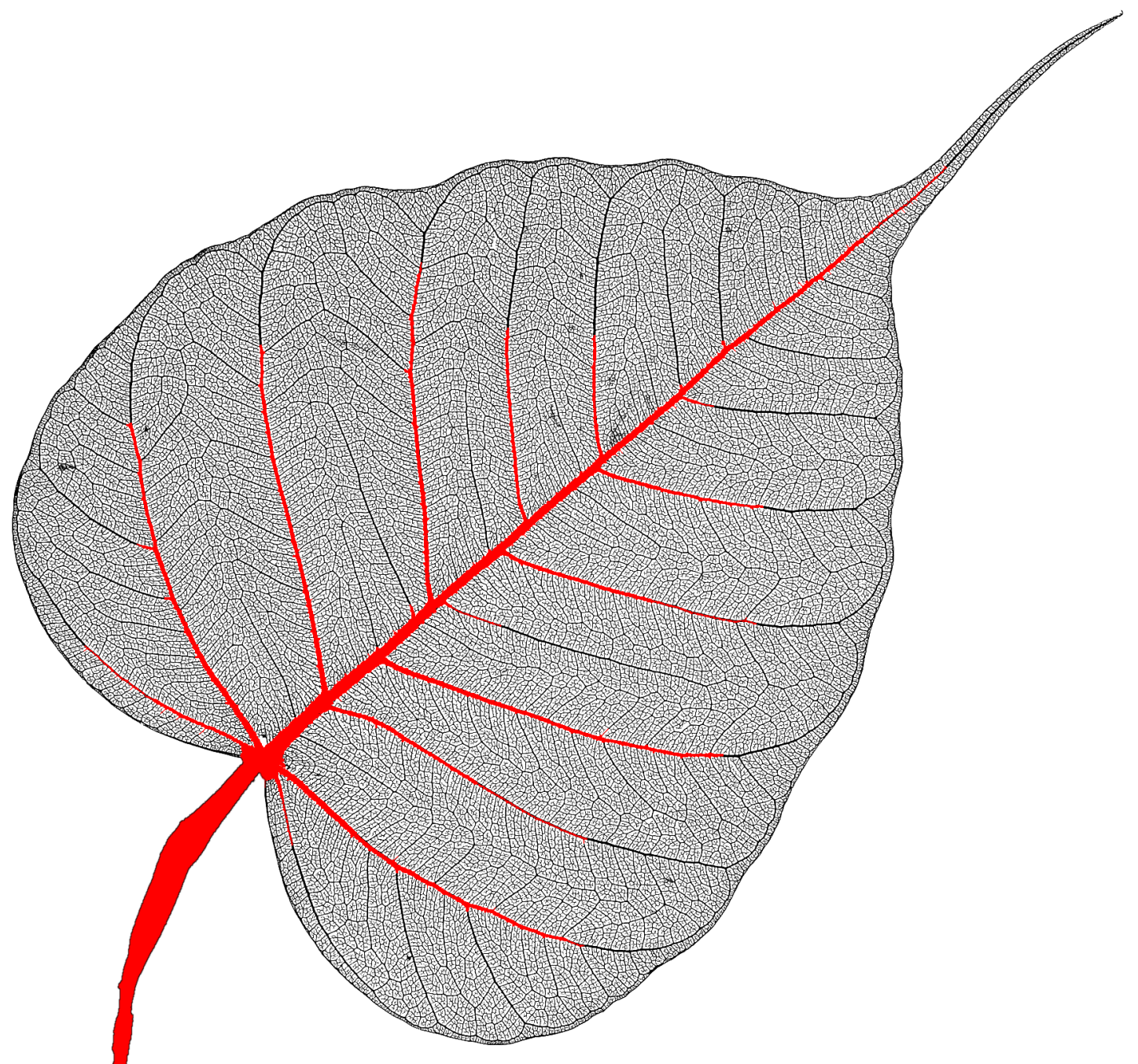

Karolina Janeczek Portalska 


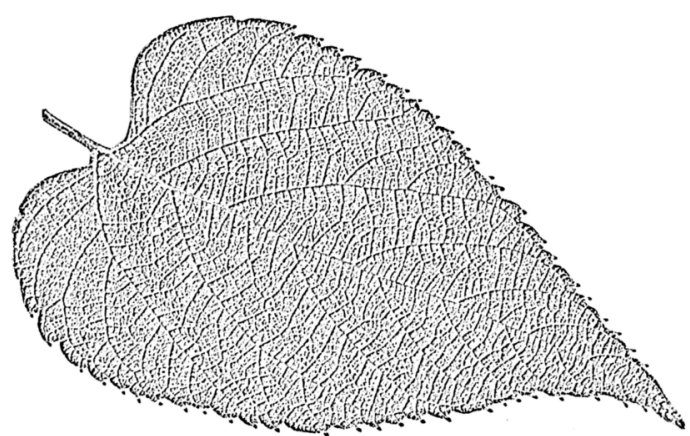

ISBN : 978-90-365-3644-8 


\section{Tissue Vascularization with Endothelial-like Mesenchymal Stromal Cells}

Karolina Janeczek Portalska

2014 


\section{Members of the Graduation Committee}

\section{Chairman:}

prof.dr.ir. J.W.M. Hilgenkamp

\section{Promoters:}

Prof. Dr. Jan De Boer (University of Twente)

Prof. Dr. C.A. van Blitterswijk (University of Twente)

\section{Members:}

Dr. Jacqueline Alblas (University Medical Center Utrecht)

Dr. Robert H. Geelkerken (Medisch Spectrum Twente)

Prof. Dr. Martin C. Harmsen (University of Groningen)

Dr. Lorenzo Moroni (University of Twente)

Prof. Dr. Marcel Karperien (University of Twente)

Prof. Dr. Anton-Jan van Zonneveld (Leiden University Medical Center)

\section{TISSUE VASCULARIZATION \\ WITH ENDOTHELIAL-LIKE MESENCHYMAL STROMAL CELLS}

Karolina Janeczek Portalska

PhD Thesis, University of Twente, Enschede, The Netherlands

This publication was supported by the NBTE

(Dutch association for Biomaterials and Tissue Engineering)

The research described in this thesis was supported by

De Stichting voor de Technische Wetenschappen (STW) and by Anna Fonds

\section{ISBN: 978-90-365-3644-8}

Cover design: M. Portalski

Copyright: K. K. Janeczek Portalska, 2014, Enschede, The Netherlands. Neither this thesis nor its parts may be reproduced without written permission of the author. 


\title{
TISSUE VASCULARIZATION WITH ENDOTHELIAL-LIKE MESENCHYMAL STROMAL CELLS
}

\section{DISSERTATION}

\author{
to obtain \\ the degree of doctor at the University of Twente, \\ on the authority of the rector magnificus, \\ Prof. Dr. H. Brinksma \\ on account of the decision of the graduation committee, \\ to be publicly defended \\ on Thursday, April $10^{\text {th }}$, 2014, at 12.45 hrs
}

by

Karolina Janeczek Portalska

Born on February $23^{\text {rd }}, 1984$

in Kraków, Poland 


\section{Promoters:}

Prof. Dr. Jan De Boer (University of Twente)

Prof. Dr. C.A. van Blitterswijk (University of Twente) 


\section{Summary}

Although most tissues in the human body have self-renewal capabilities, there are defects, e.g. caused by trauma or disease, which are beyond regenerative potential. Tissue engineering offers a possibility to heal such defects without the necessity of finding a suitable graft donor. While a number of in vivo studies concerning tissue engineering for tissues replacement have been successfully performed, a need occurred to introduce vascular networks in newly formed tissues in order to guarantee their survival and correct functionality. Therefore, tissue engineering of blood vessels and capillaries is a widely investigated aspect necessary for various applications.

This thesis describes the in vitro and in vivo biological evaluation of the potential of human mesenchymal stromal cells (hMSC) to differentiate towards endothelial-like cells (EL-MSC). The success of regenerative strategies where EL-MSCs are applied relies on the following requirements: the differentiation protocol should be simple and robust, the issue of donor-related variability needs to be addressed, clinically approved ways of delivery must to be provided and finally, the usefulness of EL-MSCs in certain applications ought to be proven. Since hMSCs are already widely used in various therapies, EL-MSCs are likely to fulfil all these requirements.

Chapter 1 summarizes the content of this thesis. In chapter 2, a general review of literature is given, with the particular emphasis on emerging strategies for blood vessel engineering. Various cell types, biomaterials and approaches to generate functional vessels are described. Chapter 3 contains the evaluation of hMSC endothelial differentiation. The robustness of the presented protocol is assessed in chapter 4 together with the estimation of hMSC in vitro expansion potential when endothelial differentiation is required. Several molecular markers are also suggested for predicting whether cells obtained from a particular donor can be used in therapies that require EL-MSC application. Chapters 5 and 6 contain the description of two potential strategies to deliver EL-MSC for vascularization purposes. Modular tissue engineering approaches based on collagen modules and injectable in-situ-forming dextran-based hydrogel applications are presented. Two strategies are described to improve biological performance of EL-MSCs: creation of 3-dimensional structures allowing for easier vessel in-growth and alternatively, applying growth factor stimulation to induce angiogenesis from host vessels. The potential applications of EL-MSCs for tissue engineering purposes are described in chapter 7 and 8. In chapter 7 the beneficial influence of EL-MSCs on bone formation is presented while chapter 8 shows how EL-MSCs can be used for 
improving vascularization of islets of Langerhans. Finally, chapter 9 summarizes and discusses all the results presented in this thesis.

Overall, this thesis presents a multifactorial approach towards improving vascularization of both in vitro and in vivo engineered tissues and also suggests future developments and applications of endothelial-like cells derived from MSCs . 


\section{Samenvatting}

Alhoewel de meeste weefsels in het menselijk lichaam zelf-vernieuwende capaciteiten hebben, zijn er defecten, bijvoorbeeld veroorzaakt door trauma of ziekte, die verder gaan dan de regeneratieve mogelijkheden. Weefselregeneratie biedt de mogelijkheid om zulke defecten te genezen zonder dat het zoeken naar een geschikte weefseldonor nodig is. Sinds een aantal in vivo weefselregeneratiestudies voor weefselvervanging succesvol uitgevoerd zijn, is er vraag naar het introduceren van vasculaire netwerken in nieuw gevormde weefsels om de overleving en functionaliteit te verbeteren. Om die reden is de weefselregeneratie van bloedvaten en capillairen een veel onderzocht aspect dat waardevol is voor verschillende toepassingen.

Dit proefschrift beschrijft de in vitro en in vivo biologische evaluatie van de mogelijkheid van humane mesenchymale stromale cellen (hMSC) om te differentiëren naar endotheel-achtige cellen (EL-MSC). Het succes van regeneratieve strategieën met behulp van EL-MSC berust op de volgende eisen: het differentiatieprotocol moet simpel en robuust zijn; er moet gekeken worden naar het probleem van donor-gerelateerde verschillen; er moeten klinisch goedgekeurde methoden zijn voor aflevering in het lichaam en tot slot moet de bruikbaarheid van EL-MSC in bepaalde toepassingen bewezen zijn. Omdat hMSC al veel gebruikt worden in verschillende therapieën, is er een grote kans dat EL-MSC aan deze eisen zullen voldoen.

Hoofdstuk 1 vat de inhoud van dit proefschrift samen. In hoofdstuk 2 wordt een algemeen overzicht gegeven van de literatuur, met de nadruk op de opkomende strategieën voor bloedvatregeneratie. Verschillende celtypes, biomaterialen en methoden om functioneel weefsel te regenereren zijn beschreven. Hoofdstuk 3 bevat de evaluatie van hMSC endotheeldifferentiatie. De kracht van het beschreven protocol wordt bekeken in hoofdstuk 4 samen met de bepaling van het hMSC in vitro expansieprotocol voor endotheeldifferentiatie. Verschillende moleculaire markers worden gesuggereerd voor het voorspellen of cellen afkomstig van een bepaalde donor geschikt zijn in therapieën waar EL-MSC benodigd zijn. Hoofdstukken 5 en 6 bevatten de beschrijving van twee mogelijke strategieën om EL-MSC in het lichaam af te leveren voor vascularisatie doeleinden. Modulaire weefselregeneratiemethoden gebaseerd op collageenmodules en injecteerbare in-situ-vormende dextraan-gebaseerde hydrogeltoepassingen worden beschreven. Twee strategieën om de biologische functie van EL-MSC te verbeteren worden beschreven: het creëren van driedimensionale structuren die ingroei van vaten makkelijker maken en het toevoegen van groeifactoren voor het stimuleren van 
angiogenese van gastheervaten. De mogelijke toepassingen van EL-MSC voor weefselregeneratie doeleinden worden beschreven in hoofdstuk 7 en 8 . In hoofdstuk 7 wordt de positieve invloed van EL-MSC op botvorming beschreven en in hoofdstuk 8 wordt beschreven hoe EL-MSC gebruikt kunnen worden voor de verbetering van vascularisatie van eilandjes van Langerhans. Tot slot worden in hoofdstuk 9 de resultaten uit dit proefschrift samengevat en bediscussieerd.

Kort samengevat beschrijft dit proefschrift een multifactoriële aanpak voor de verbetering van vascularisatie van zowel in vitro als in vivo geregenereerde weefsels en suggereert toekomstontwikkelingen en toepassingen van endotheel-achtige cellen afkomstig van MSC. 


\section{Streszczenie}

Wiele tkanek ludzkiego organizmu wykazuje całkowitą lub częściową zdolność do regeneracji, jednak niektóre ubytki, spowodowane urazem lub chorobą są zbyt rozległe aby ten proces zaszedł samoistnie. Inżynieria tkankowa daje możliwość naprawy takich ubytków bez konieczności przeszczepu tkanek pobranych od obcego dawcy. Liczne doświadczenia in vivo dotyczacce wykorzystania inżynierii tkankowej do uzupełniania poważnych ubytków wykazały konieczność unaczynienia nowo powstałych tkanek aby zapewnić ich pełną funkcjonalność. Tym samym badania dotyczące inżynierii tkankowej naczyń krwionośnych stanowią obecnie ważny aspekt przy wprowadzaniu nowych terapii.

Niniejsza praca przedstawia badania in vitro i in vivo dotyczacce biologicznego potencjału ludzkich mezenchymalnych komórek macierzystych (human mesenchyma stromal cells, hMSC) zróżnicowanych w kierunku komórek podobnych do komórek endotelialnych (endothelial-like mesenchymal stromal cells, EL-MSC). Powodzenie terapii opartej na wykorzystaniu tych komórek zależy od kilku czynników: różnicowanie powinno być nieskomplikowane i wydajne, jak również proces ten nie powinien być zależny od źródła pochodzenia komórek (odporny na zmiany związane z różnorodnością hMSC od różnych dawców). Konieczne jest także opracowanie metod wprowadzania EL-MSC do organizmu pacjenta oraz potwierdzenie ich korzystnego wpływu na przebieg terapii. Ponieważ niezróżnicowane MSC są obecnie szeroko stosowane w medycynie regeneracyjnej, istnieje duża szansa, iż powyższe warunki mogą być spełnione także w przypadku EL-MSC.

Pierwszy rozdział prezentowanej pracy streszcza ogólne założenia i wyniki badań przedstawione w kolejnych rozdziałach. Rozdział drugi podsumowuje dotychczasowe osiągnięcia medycyny regeneracyjnej w zakresie inżynierii tkankowej naczyń krwionośnych z naciskiem na praktyczne zastosowanie prowadzonych badań. Omówione zostały zarówno typy komórek i biomateriałów jak również metody konstruowania i wprowadzania nowo zbudowanych żył w kontekście różnych terapii. W rozdziale trzecim opisane jest różnicowanie MSC w kierunku EL-MSC z uwzględnieniem metod oceny wydajności tego procesu. Rozdział czwarty przedstawia porównanie wydajności opisanego różnicowania w przypadku zastosowania komórek pochodzących od różnych dawców. Przedstawione są również badania dotyczące wyodrębnienia markerów molekularnych pozwalających przewidzieć, czy komórki wyizolowane od danego dawcy będą mogły zostać wykorzystane do terapii wymagających konstruowania naczyń 
krwionośnych. Rozdziały piąty i szósty zawierają opis dwóch różnych metod wprowadzania EL-MSC do organizmu pacjenta. Rozdział piąty omawia podejście oparte na modularnej inżynierii tkankowej opartej na modułach kolagenowych, podczas gdy w rozdziale szóstym opisane jest zastosowanie opartych na dekstranie żeli formowanych in situ. Metody te zakładają ulepszenie wydajności w tworzeniu naczyń krwionośnych przez EL-MSC dwiema różnymi drogami: poprzez zapewnienie odpowiednich struktur trójwymiarowych oraz poprzez dostarczenie stymulacji czynnikami wzrostowymi. W rozdziałach siódmym i ósmym przedstawione zostały propozycje wykorzystania EL-MSC we współcześnie stosowanych terapiach. W rozdziale siódmym opisany został korzystny wpływ obecności EL-MSC na regenerację kości, rozdział ósmy dotyczy natomiast unaczyniania wysp Langerhansa przy przeszczepach stosowanych w terapii pacjentów z cukrzycą. Na koniec, w rozdziale dziewiątym, omówione zostały wszystkie rezultaty przedstawione $\mathrm{w}$ tej pracy w kontekście możliwego wykorzystania ich w medycynie regeneracyjnej.

Podsumowując, niniejsza praca prezentuje wielokierunkowe podejście do doskonalenia metod unaczyniania tkanek i przedstawia możliwości dalszego rozwoju tej dziedziny z wykorzystaniem EL-MSC. 


\section{Contents}

1 General introduction 1

1.1 Regenerative medicine . . . . . . . . . . . . . . . . . . . 1

1.2 Tissue Engineering . . . . . . . . . . . . . . . . . . . 1

1.3 Aim and outline of this thesis $\ldots \ldots \ldots \ldots \ldots \ldots$

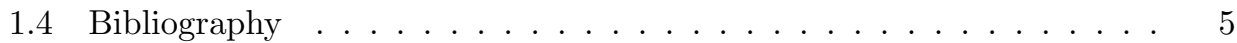

\begin{tabular}{|lll}
\hline 2 & Tissue engineering of blood vessel & 7
\end{tabular}

2.1 Blood vessels and vascularization $\ldots \ldots \ldots \ldots \ldots$

2.2 Blood vessel failure . . . . . . . . . . . . . . . . . . . . . 8

2.3 Large vessel engineering $\ldots \ldots \ldots \ldots$

2.4 Engineering of capilaries $\ldots \ldots \ldots \ldots \ldots \ldots$

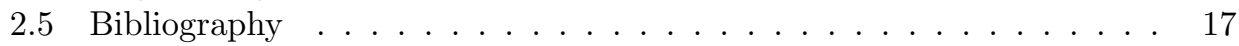

\begin{tabular}{|lll}
3 & Endothelial differentiation of MSC & 27
\end{tabular}

3.1 Introduction . . . . . . . . . . . . . . . . . . 27

3.2 Materials and methods . . . . . . . . . . . . . . . . 30

3.3 Results . . . . . . . . . . . . . . . . . . . . . . . 35

3.4 Discussion . . . . . . . . . . . . . . . . . . . . . . 44

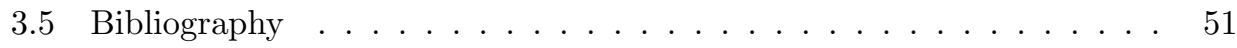

$\begin{array}{lll}4 \text { Donor variation } & 59\end{array}$

4.1 Introduction . . . . . . . . . . . . . . . . . . . . 60

4.2 Materials and methods . . . . . . . . . . . . . . . . . . . 61

4.3 Results . . . . . . . . . . . . . . . . . . . . . . . . . . . . 64

4.4 Discussion . . . . . . . . . . . . . . . . . . . . . . . . 72

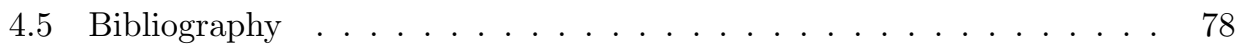

$\begin{array}{llr}5 \text { Collagen modules } & 87\end{array}$

5.1 Introduction . . . . . . . . . . . . . . . . . . . . . 87

5.2 Materials and methods . . . . . . . . . . . . . . . . . . . . 89

5.3 Results . . . . . . . . . . . . . . . . . . . . . . . . 92

5.4 Discussion $\ldots \ldots \ldots \ldots \ldots \ldots \ldots \ldots$

5.5 Bibliography $\ldots \ldots \ldots \ldots \ldots \ldots \ldots \ldots$ 
6 Boosting angiogenesis in hydrogels 107

6.1 Introduction . . . . . . . . . . . . . . . . . . . 108

6.2 Materials and Method . . . . . . . . . . . . . . . . . . . . . . 109

6.3 Results. . . . . . . . . . . . . . . . . . . . . . . . . . . . . . . . . . . . . . . . .

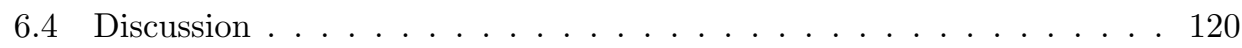

6.5 Bibliography . . . . . . . . . . . . . . . . . . 124

\begin{tabular}{|lll}
\hline 7 & hMSC for bone and vessel engineering & 127
\end{tabular}

7.1 Introduction . . . . . . . . . . . . . . . . . . 127

7.2 Materials and methods . . . . . . . . . . . . . . . . . . . . . . . . 129

7.3 Results and Discussion . . . . . . . . . . . . . . . . . . . . . 133

7.4 Conclusions . . . . . . . . . . . . . . . . . . . . . 139

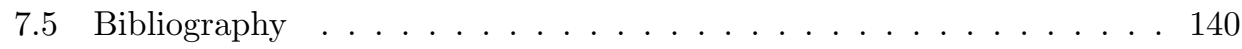

8 EL-MSC for islet vascularization 143

$8.1 \quad$ Introduction . . . . . . . . . . . . . . . . . . . . . . 143

8.2 Research design and methods . . . . . . . . . . . . . . . . . . . . . 145

8.3 Results. . . . . . . . . . . . . . . . . . . . . . . . . . . . . . . . . . . . . . . . . . . . . . . .

8.4 Discussion . . . . . . . . . . . . . . . . . . . . . . . 151

8.5 Bibliography . . . . . . . . . . . . . . . . . . . 155

$\begin{array}{lll}9 & \text { General discussion } & 159\end{array}$

9.1 Tissue engineering of blood vessels . . . . . . . . . . . . . . . . . . . 159

9.2 Factors influencing EL-MSC applications in therapy . . . . . . . . . . 160

9.3 Concluding remarks and future perspectives . . . . . . . . . . . . . . . 162

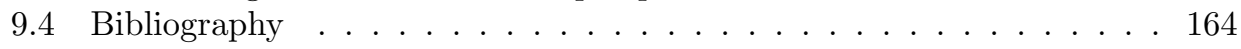

\begin{tabular}{ll}
\hline List of Publications & 167
\end{tabular}

\begin{tabular}{lr}
\hline Curriculum Vitae & 169
\end{tabular}

\begin{tabular}{|ll}
\hline Acknowledgements & 171
\end{tabular} 


\section{Chapter 1}

\section{General introduction and thesis outline}

\subsection{Regenerative medicine}

Regenerative medicine is a biomedical research area which investigates the possibility of stimulating the body's natural ability to repair damaged tissue and organs or to imitate such repair in order to guarantee functional recovery. This field emerged as an answer to the growing need for healing serious diseases concerning various tissues, due to the increase in average human lifespan. Currently, the main goal of regenerative medicine is to preserve human independence and productivity but it also has the potential to solve the problem of the shortage of organs available from donations compared to the number of patients that require life-saving organ transplantation. Due to such a broad scope, regenerative medicine is based on both basic scientific disciplines such as biology, immunology, chemistry and physics and on more application-oriented disciplines such as tissue engineering and biomaterials research. The current challenge in regenerative medicine is to combine state-of-the-art knowledge into a new therapy paradigm. Since some tissues are unable to heal themselves even after application of various stimulants, it is necessary to design a strategy that will allow to manufacture healthy tissue without relying on the regenerative potential of patient's own tissues.

\subsection{Tissue Engineering}

Tissue engineering has developed as a multidisciplinary scientific field that implements the principles of biology, medicine and engineering to obtain tissue substitutes for restoration, maintenance and improvement of diseased or damaged tissues [1, 2]. For many years the only possible form of repairing damaged tissues was transplantation of biological material collected from a donor (e.g. blood transfusion or bone grafting). The best results were obtained when autologous grafts were applied [3], even though in such cases there are always issues of donor site morbidity and the need for additional surgery inducing risk of infection at the harvest site [4]. Unfortunately, autologous 
sources are limited and not suitable in case of several diseases such as autoimmune diseases or osteoporosis $[57$. On the other hand, the main problem with allogenic transplantations is the risk of immune rejection and disease transfer. Despite these problems, allografts represent approximately $30 \%$ of all bone grafts used in the clinic. Nevertheless, there are tissues where allogenic transplantation cannot be applied, e.g. endothelial cells obtained from allogenic sources were shown to induce a chronic immune reaction in the patients 8 and therefore their application for clinical purposes is not an option. An alternative method to tissue grafting is tissue engineering where three main strategies can be distinguished 9]. The simplest strategy is implantation of freshly isolated or cultured cells in the damaged tissue. This approach includes only very small interference in the isolated material (e.g. stem cells are reported to be able to replace damaged heart muscle cells and establish new blood vessels to supply them with nutrients $[10,11])$. The other two methods are more complex. A complete threedimensional tissue graft can be generated in vitro from cells and artificial matrices and implanted afterwards, or the artificial matrix could be implanted directly into the injured tissue to stimulate the body's own cells to promote local tissue repair (see Figure 1.1].

Regardless of the chosen method, latest developments in the field show that very often there is another issue that needs to be tackled. Providing proper vascularization of newly formed or regenerated tissue has been found to be crucial to maintain tissue homeostasis. Most of the tissues within the human body (except e.g. cartilage) are highly vascularized and rely on the blood vessels to supply nutrients and oxygen to the

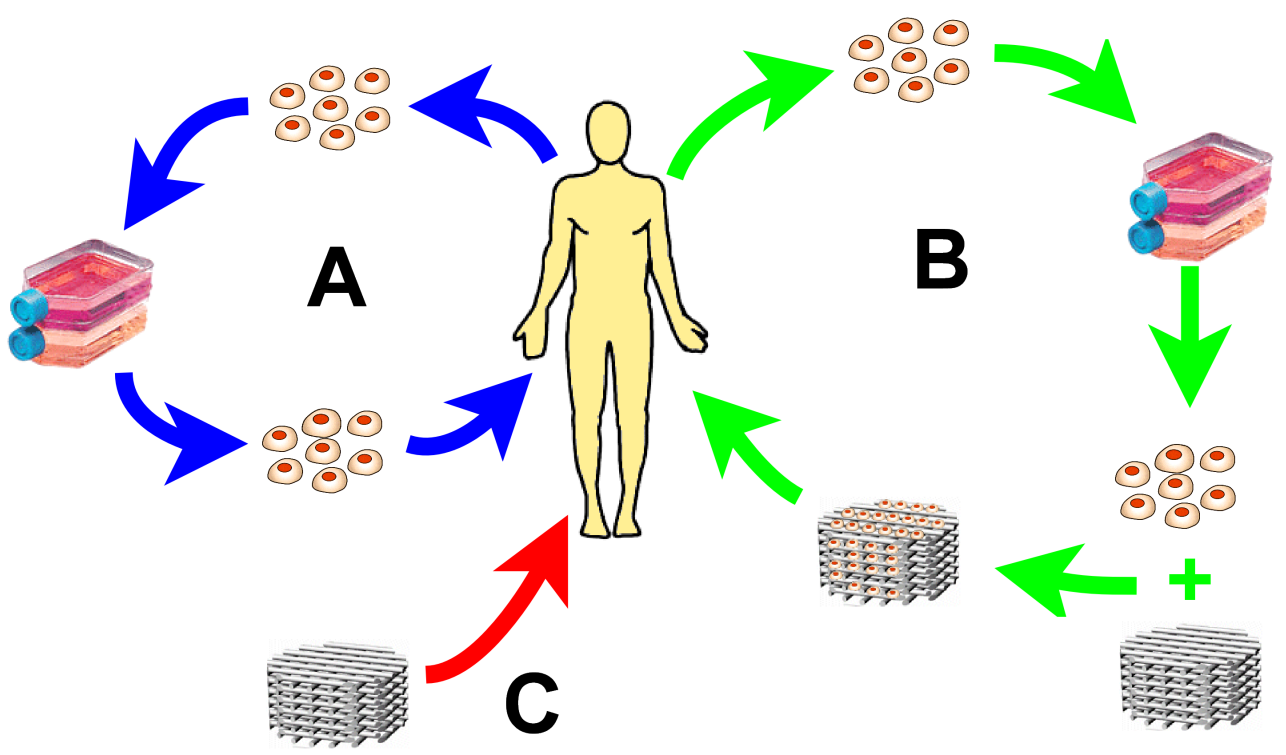

Figure 1.1: Basic tissue engineering strategies 
individual cells. Since the diffusion limit of oxygen is around 100-200 $\mu \mathrm{m}$, proper blood vessel density within the tissue is required. The same is true for newly engineered tissues. Therefore, tissue engineering of blood vessels and methods of introducing them into in vitro or in vivo formed tissue is a widely investigated aspect necessary for various applications.

So far, most studies in tissue engineering relied on blood vessel in-growth from the host after implantation. Several strategies have been designed to improve this process, such as introduction of pro-angiogenic growth factors or cells with high paracrine activity in the construct. Such methods were shown to improve the vascularization of newly formed tissue but were not sufficient to maintain tissue homeostasis in case of larger constructs. Therefore, graft vascularization prior to or upon implantation became a widely investigated topic 12 . Particularly, introduction of cells that could create a vascular network within the implant came to be an issue of interest. These cells will be described in details in chapter two of this thesis, together with our candidate for an ideal cell source for tissue vascularization described further in chapter three.

\subsection{Aim and outline of this thesis}

Although a remarkable amount of research has been performed on the most efficient ways of promoting tissue vascularization for applications in regenerative medicine, there are still aspects that need to be improved. The general goal of this thesis is to evaluate the potential of human mesenchymal stromal cells (hMSC), differentiated towards endothelial-like cells, in improving angiogenesis and vasculogenesis.

Chapter 2 provides a general overview of the current state-of-the-art in vascular engineering. An overall description of cell types and biomaterials that are used in this field is provided together with the evaluation of emerging strategies.

In Chapter 3 the ability of hMSCs to differentiate towards endothelial-like cells is evaluated. A protocol for hMSC differentiation is presented which yields cells capable of replacing endothelial cells in various applications. hMSCs are shown to acquire specific endothelial cell properties, both phenotypically and functionally. The potential consequences of this phenomenon are described together with the possible applications of endothelial-like MCSs in various therapies.

Chapter 4 describes the donor variability among hMSCs as far as endothelial differentiation is concerned. The ability to differentiate towards an endothelial phenotype of hMSCs obtained from 20 donors is assessed and the robustness of the applied differentiation protocol is demonstrated. In addition, the effect of prolonged in vitro expansion on the multipotency of hMSCs is examined and its limited influence on endothelial differentiation is described. Moreover, the correlation between endothelial differentiation of hMSCs and the gene expression profile of the whole genome in the undifferentiated state of hMSCs is examined. Based on that, several candidates for 
molecular markers are provided that can be used to predict the potential of hMSCs to differentiate into endothelial-like cells.

In Chapter 5, we demonstrate how modular tissue engineering can be used in the context of MSC delivery for vascularization purposes. Clinically relevant modules created from bovine collagen are shown to be suitable to deliver endothelial-like MSCs in the place where vascularization is needed. We describe the possibility to adjust this method such that it becomes fully injectable and thus minimally invasive.

Chapter 6 demonstrates another way of enhancing angiogenesis and vasculogenesis in tissue engineered constructs. The use of endothelial-like MSCs in combination with injectable dextran-hyaluronic acid hydrogels (Dex-g-HA) in vascularization is investigated. Several combinations of cell types and hydrogel modifications together with reciprocal influences between cells and matrixes are examined for selecting the best one for vascular tissue engineering. This chapter proves that Dex-g-HA is an efficient delivery vehicle for VEGF, and that functional neo-vascularization can be achieved in vitro and in vivo with the combination of Dex-g-HA and endothelial-like MSCs.

Chapter 7 deals with the possible applications of endothelial-like MSCs in bone tissue engineering. We show that human MSCs can be used a single cell source for both endothelial-like cells and bone forming osteblasts in vivo. Addition of EL-MSCs cells to a previously developed bone-forming system had a positive effect on the amount of obtained bone in all but one case. We hypothesize that this effect is induced by endothelial-like MSCs via their trophic effect. Studies performed in vitro reveal that endothelial-like MSCs did not influence the expression of osteogenic and angiogenic markers in the construct. Due to the limited amount of samples we were not able to conclude whether EL-MSCs significantly increase the amount of obtained bone nor what could be the mechanism of their influence. Therefore, further studies are required to explore the potential of these cells in the field of bone tissue engineering.

In Chapter 8, endothelial-like MSCs are shown to improve vascularization of islets of Langerhans. Introducing dense vascular network is of crucial importance in islets transplantation for diabetic patients. Only then the islets can survive and the insulin can be efficiently delivered into the blood stream. Previous studies with clinically non-applicable endothelial cells demonstrated that this improvement speeds up vessel in-growth in the islets and improves their survival. This in vitro study shows that coating islets of Langerhans by endothelial-like MSCs improves their sprouting ability without hampering their functionality.

Chapter 9 provides a collective overview of obtained results and presents future perspectives of endothelial-like MSC application in tissue engineering. 


\subsection{Bibliography}

[1] J. P. Vacanti and R. Langer. Tissue engineering: the design and fabrication of living replacement devices for surgical reconstruction and transplantation. Lancet, 354 Suppl 1:SI32-4, 1999.

[2] R. Langer and J. P. Vacanti. Tissue engineering. Science, 260(5110):920-6, 1993.

[3] H. K. Outerbridge, A. R. Outerbridge, and R. E. Outerbridge. The use of a lateral patellar autologous graft for the repair of a large osteochondral defect in the knee. The Journal of Bone \& Joint Surgery, 77(1):65-72, 1995.

[4] Edward D. Arrington, William J. Smith, Henry G. Chambers, Allan L. Bucknell, and Nelson A. Davino. Complications of iliac crest bone graft harvesting. Clin Orthop Relat Res, 329:300-309, 1996.

[5] E. R. Carlson, R. E. Marx, and B. E. Buck. The potential for hiv transmission through allogeneic bone. a review of risks and safety. Oral Surg Oral Med Oral Pathol Oral Radiol Endod, 80(1):17-23, 1995.

[6] A. D. Jacobs, J. E. Levenson, and D. W. Golde. Induction of acute corneal allograft rejection by alpha-2 interferon. Am J Med, 82(1):181-2, 1987.

[7] P. Salari Sharif, M. Abdollahi, and B. Larijani. Current, new and future treatments of osteoporosis. Rheumatol Int, 31(3):289-300, 2011.

[8] R. N. Salomon, C. C. Hughes, F. J. Schoen, D. D. Payne, J. S. Pober, and P. Libby. Human coronary transplantation-associated arteriosclerosis. evidence for a chronic immune reaction to activated graft endothelial cells. Am J Pathol, 138(4):791-8, 1991.

[9] L. G. Griffith and G. Naughton. Tissue engineering-current challenges and expanding opportunities. Science, 295(5557):1009-14, 2002.

[10] A. P. Beltrami, K. Urbanek, J. Kajstura, S. M. Yan, N. Finato, R. Bussani, B. Nadal-Ginard, F. Silvestri, A. Leri, C. A. Beltrami, and P. Anversa. Evidence that human cardiac myocytes divide after myocardial infarction. $N$ Engl J Med, $344(23): 1750-7,2001$.

[11] K. A. Jackson, S. M. Majka, H. Wang, J. Pocius, C. J. Hartley, M. W. Majesky, M. L. Entman, L. H. Michael, K. K. Hirschi, and M. A. Goodell. Regeneration of ischemic cardiac muscle and vascular endothelium by adult stem cells. J Clin Invest, 107(11):1395-402, 2001.

[12] D. H. Ausprunk, D. R. Knighton, and J. Folkman. Vascularization of normal and neoplastic tissues grafted to the chick chorioallantois. role of host and preexisting graft blood vessels. Am J Pathol, 79(3):597-618, 1975. 



\title{
Chapter 2
}

\section{Tissue engineering of blood vessel: from large vessels towards capillaries}

Karolina Janeczek Portalska, Hugo Fernandes, Daniel Saris, Clemens van Blitterswijk and Jan de Boer

\begin{abstract}
Vascular grafts are required to treat various disorders such as myocardial infarction and ischemic diseases. In addition, introduction of a vascular network is necessary for many tissue engineering strategies. Due to the limited number of autologous vessels that can be surgically harvested, an alternative source of vascular graft material needs to be developed. Cell-free synthetic grafts have been developed, combining desired mechanical properties of the implanted materials with the capability of longterm survival within the body without development of thrombosis, calcification or immune-rejection. The addition of cells can accelerate the formation of vascular grafts and provide enhanced biological properties when compared to cell-free grafts. In this manuscript, we describe the progress in tissue engineering of blood vessels and discuss the source of cells, biomaterials and combination thereof. We also describe the specific challenges in fabricating small vessels and capillaries. This is crucial when treating peripheral ischemic diseases and implanting tissue constructs where a new vascular network must be developed within the graft shortly after implantation. Special emphasis is given to the challenge of bringing these strategies to the clinic.
\end{abstract}

\subsection{Blood vessels and vascularization}

Blood vessels transport blood and thus nutrients and waste products throughout the body. There are three types of vessels: the macrovessels (veins and arteries), which then branch into microvessels (venules and arterioles) which subsequently branch into 
capillaries. The capillaries provide the cells in the body with nutrients and remove the waste products produced by the cellular metabolism.

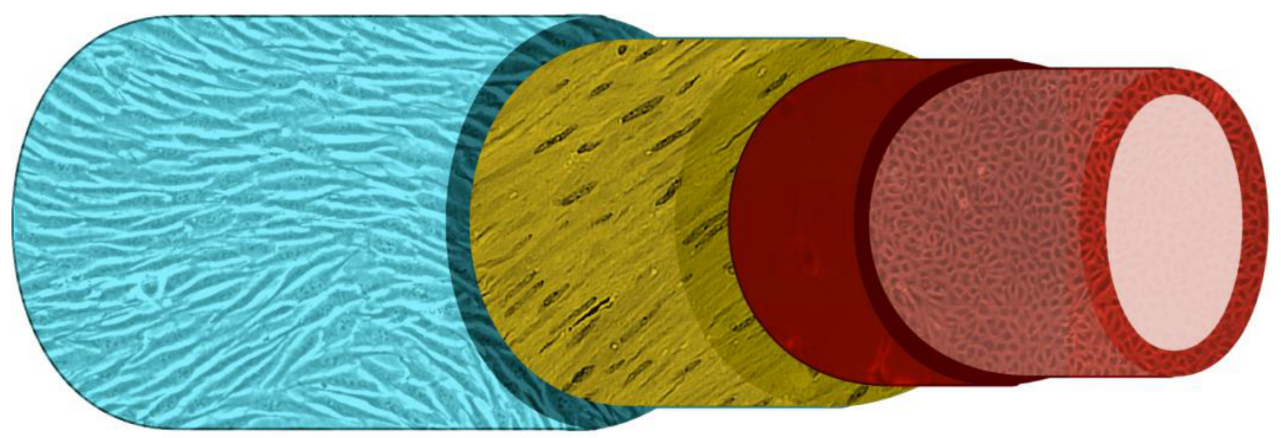

\section{Endothelial Cells}

\section{Basal lamina and pericytes}

\section{Smooth muscle cells}

\section{Fibroblasts}

Figure 2.1: Schematic representation of a vessel.

Macrovessels and microvessels are made of three layers (Figure 2.1): an inner lining composed of endothelial cells followed by a middle layer of a basal lamina and pericytes (a specialized smooth muscle cell) and then a layer of smooth muscle cells (SMC) and fibroblasts. Endothelial cells (EC) provide a selective permeable surface that prevents blood components from attaching and forming thrombus [1]. This layer is also responsible for controlling vessel tone and leukocyte adhesion. Pericytes participate in vessel stabilization and maturation [2, 3], blood flow regulation $[3$ and are thought to be a candidate cell source for tissue regeneration [4,5]. SMCs and fibroblasts provide integrity to the vessels and are mostly responsible for their characteristic mechanical properties [6]. Capillaries, due to their function, do not require the outermost layer of SMCs and fibroblasts.

\subsection{Blood vessel failure}

The proper functioning of the circulatory system is crucial to maintain homeostasis of the body. All tissues need to receive sufficient levels of oxygen and nutrients, and efficient removal of waste products is paramount to maintain local homeostasis. Blood vessel pathologies such as myocardial infarction and ischemic diseases have 
lately become a leading cause of death. For example, cardiovascular diseases alone are estimated to be the cause of death of over 23 million people by 2030 [7. Several reasons for blood vessel failure are known. Arteriosclerosis, which is responsible for the buildup of plaques in the inner layer of the blood vessels results in a reduction of the lumen which, if not treated, can lead to vessel rupture, clot formation or even total obstruction of the vessel $[8$. These effects pose a major risk for heart attacks and amputation of limbs due to the concomitant lack of oxygen followed by cell death. Puncturing can also result in vessel pathologies, and are common in patients that require regular dialysis due to kidney diseases. Regular puncturing of the vessel leads to vessel hardening, healing problems and, concomitantly, vessel necrosis [9].

Surgically harvested autologous grafts have been widely applied in such situations but frequently, limitations and complications are encountered [10]. Although autologous material remains the preferable source for grafted vessels, this source is often seriously limited or not available, for instance when a patient only has a low number of good quality vessels which can be isolated without collateral damage [1].

Last but not least, necrosis of capillaries is commonly observed in diseases such as peripheral arterial disease and diabetes, hampering oxygen delivery to the limbs and hence reducing the healing capacity of the tissues. As a consequence, gangrene and tissue necrosis are prevalent in these patients and, if left untreated, limb amputation is the only option available. Even more importantly, transplantation is not a method of choice in illnesses connected with capillary degeneration, because it is impossible to reproduce the complexity of the capillary system 12 . Proper vascularization is also of crucial importance in tissue engineering of large tissue constructs. Without a strategy to speed up the process of vascularization of the graft, ischemia will occur in implanted tissues leading to graft failure. It is widely recognized that generation of a functional vasculature is crucial to allow clinical application of many in vitro engineered tissues. So far, only a few engineered tissues and organs (e.g. bladder, skin and cartilage 1315 ) achieved clinical success.

\subsection{Large vessel engineering}

The classical tissue engineering approach has been used to generate large vessels, in which various types of cells have been used in combination with a suitable scaffold. After implantation at the injury site, the scaffold is meant to degrade and be replaced by extracellular matrix (ECM) produced by cells and the cells should organize into native tissue. Below, we will review cell sources, scaffold types and techniques to combine them.

\subsubsection{Cell sources}

The ideal cell source for vessel engineering should be non-immunogenic, easy to isolate and expand in culture and capable of differentiating into the different cell types comprising a vessel. Similar to other fields of tissue engineering, many studies in blood 
vessel tissue engineering have focused on autologous cells. For instance, tissue engineered blood vessels have been engineered within roughly 10 weeks using ECs and SMCs isolated from healthy patients 16 . However, because most candidates for vessel transplantation entail patients with underlying cardiac conditions, one can anticipate problems with the proposed approach. Alternatives are therefore needed to shorten the time required to obtain a functional vessel and improve its clinical performance. Moreover, ECs and SMCs have poor proliferative capacity, 17, 18]. Allogenic cells have been proposed as an alternative, after careful consideration of the possible immune response elicited by these cells. Whereas the use of allogenic SMCs may be possible, the same cannot be said for allogenic ECs, since a chronic immune reaction was observed after their implantation 19,20 .

Endothelial and smooth muscle progenitor cells (EPC and SMPC) have been investigated as cell source for blood vessel TE as well, because they have the ability to differentiate towards their respective lineages $21 \mid 24]$. EPCs can readily be isolated from peripheral blood or umbilical cord blood based on their CD34+KDR+AC133+ phenotype 25, 26]. Convincing evidence showing improvements in vessel functionality upon EPC implantation was observed 27, 29], but recent results in animal studies raised questions about their mechanism of action [30]. The increase in neovascularization observed in the presence of EPCs may be based on their secretion of pro-angiogenic factors rather than a direct contribution to the formation of new vessels [31. On the other hand, evidence exists showing that EPCs can contribute to vessel walls [32]. Unfortunately, the number of circulating EPCs as well as their functionality is severely affected in several cardiac-related diseases despite the fact that a small pool of EPCs remains functional in these patients 33]. Prospective isolation of this fraction remains an appealing alternative for TE applications. Similarly to ECs, SMCs can also be obtained from the recently described smooth muscle progenitor cell population (SMPC) present in peripheral blood, bone marrow and the vascular wall [34]. Further studies are needed to unequivocally show that the SMPC population is a suitable source of unlimited and functionally active SMCs.

Another autologous source of progenitor cells are mesenchymal stromal or stem cells (MSCs). There are several sources from which MSCs can be obtained and initially it was thought that these cells can only differentiate towards the phenotypes present in originating tissues 35]. With increased research it became clear that at least for certain MSC populations this is not the case. For instance, the ability of MSCs to differentiate following a vascular smooth muscle differentiation pathway was already described in 1993 by Galmiche et al. 36]. Recent in vivo studies presented by Au et al. and Melero-Martin et al. revealed that MSC-derived cells can replace perivascular cells 37, 38 and stabilize neo-vessels upon implantation. On the other hand, several studies revealed the possibility of differentiating MSCs towards an endothelial phenotype 39 44. Oswald et al, Cao et al, Fisher et al. and Rouwkema et al. characterized MSC-derived ECs and demonstrated that in vitro such cells express typical endothelial markers: KDR and von Willebrand Factor, as well as formed characteristic capillarylike structures. 
The need to obtain a sufficient number of cells is paramount for any clinical application of tissue engineered constructs. Instead of isolating different progenitors such as EPCs and SMPCs one can use a pool of pluripotent stem cells, grow them until reaching sufficient numbers are reached and subsequently differentiate those cells into the desired cell types. For instance, Levenberg et al. showed that upon formation of embryonic bodies, embryonic stem cells (ESC) spontaneously differentiated into ECs. $\mathrm{PECAM}^{+}$cells comprise $2 \%$ of the total number of cultured ESCs within embryonic bodies and the functionality of the obtained fraction resembles ECs [45]. Several protocols for endothelial differentiation of ESCs were described and optimized for efficiency [46] but still, the risk of tumor formation hinders the deployment of this technology into the clinic. Since one single undifferentiated cell in the population is sufficient to induce the formation of tumors, protocols to obtain purified populations are in much need 47, 48.

Induced pluripotent stem cells (iPSC) are another interesting cell source, because they can be produced from the patients' own somatic cells, which solves both the ethical issues surrounding the use of ESCs and the immune rejection associated with them. They provide an unprecedented opportunity for developing novel approaches for regenerative therapy based on immuno-compatible cells and their pluripotency, including differentiation towards EC, has been demonstrated [49]. Recent work provides the field with yet another alternative: instead of reprogramming the cells to an embryonic state one can reprogram the cells directly to a new lineage via so-called partial-iPSCs (PiPS) [50, 51]. The advantage of this approach is that PiPS cells do not form tumors when implanted in vivo and still retain the capacity to differentiate into ECs upon exposure to defined media. The PiPS-derived ECs were fully functional and improved neovascularization in a hindlimb ischemic model 52. Recent work by Ginsberg et al showed that using EC-specific transcription factors one can also reprogram amniotic cells directly to ECs without transiting through a pluripotent state [53. These latest developments surely open the possibility to use the obtained cells in clinical applications where the function of ECs is impaired. It seems a matter of time until similar approaches are deployed to generate the other cell types needed to assemble a fully mature vessel. Once that is feasible, the next step would be to implement the technology in situ.

\subsubsection{Scaffolds}

The second key factor to engineer a vessel is a scaffold that will provide mechanical support and a suitable template for cell growth, migration and differentiation 54 56. General requirements for scaffolds in vessel engineering are similar to the ones in other TE fields, i.e. being biocompatible and biodegradable. Additionally, in vessel engineering, due to the direct contact with blood, they should not be thrombogenic and should exhibit elasticity in order to allow contraction. Several materials, including decellularized matrixes, natural proteins and synthetic polymeric scaffolds have been investigated for vessel engineering.

Decellularization is a process in which all cellular content is removed from a tis- 
sue while preserving the extra-cellular tissue components (mostly ECM) and most importantly, preserving the original tissue architecture [57]. Decellularization is typically accomplished by treating tissues with a combination of detergents, enzyme inhibitors and buffers [58. Decellularized vessels are fully biocompatible since they are engineered based on natural tissues. Such matrixes can fulfill all the requirements concerning mechanical properties and chemical composition. Several trials were done with animal-derived (mostly porcine) vessels to assess the biological and mechanical properties [59, 60]. However, for some people using porcine vessels as a base is not a choice e.g. due to their religious beliefs. Using vessels of human origin would be therefore the preferred solution but their limited availability hampers their extensive use 61].

Another strategy to fabricate scaffolds for vessel engineering is to use proteins isolated from ECM such as collagens, elastin or fibronectin 62, 63. Scaffolds based on such proteins will be, as in the case of decellularized vessels, fully biocompatible and biodegradable. There are several approaches to create 3D structures from natural proteins. One currently investigated method to reproduce the physical and mechanical properties of blood vessels with natural-protein scaffolds is known as electrospinning 64]. A novel hybrid approach combining elastin scaffolds isolated and purified from porcine carotids and then combined with type I collagen provided increased strength compared with collagen-only constructs 65]. Lovett et al. 66] showed that microtubes obtained from silk fibroin provided not only a scaffold suitable for EC culture but can be also downscaled towards microvascular scale $(<6 \mathrm{~mm}$ inner diameter), which is difficult to achieve with synthetic grafts.

Due to the cost and difficulties with natural protein isolation and purification there is a need for synthetic replacements. Synthetic polymers can also be more precisely modified to design desired biological and mechanical properties. Several synthetic polymers have been tested for their suitability in blood vessel engineering. Among them, poly(L-lactid-co- $\epsilon$-caprolactone) displayed very favorable properties with SMC interactions resembling the interactions in normal vessels [67. This polymer was also tested in combination with collagen. He et al. 68 showed that this combination mimics the natural ECM both morphologically and chemically. Collagen-blended polymer nanofibers enhanced viability, spreading and attachment of endothelial cells and, moreover, preserved the EC phenotype in culture. Additionally, Ma et al. 69] used non-woven polyethylene terephthalate nanofiber mats that were surface-modified to mimic the fibrous proteins in native ECM, and were grafted with gelatin. As in the previous case, such surfaces were suitable for EC culture allowing both spreading and proliferation while preserving their phenotype.

A completely different approach towards vessel engineering was presented by L'Heureux et al. in 1998 70. In this case, the authors produced tissue-engineered blood vessels exclusively using cultured human cells. Using cell sheets of SMCs and fibroblasts they managed to construct tubular structures that, after seeding with ECs, exhibited a well-defined, three-layered organization. Such structures contained also numerous extracellular matrix proteins including elastin and supported both SMC 
and EC phenotype. More importantly, the engineered vessel had a burst strength comparable to that of human vessels and displayed functional endothelium after implantation in canine models. Further study of this method proved that the cell-based approach allowed for fabrication of vessels that are biologically and clinically relevant and can be assembled exclusively from the patient's own cells 16 .

\subsection{From large vessel engineering towards capillaries}

Capillaries are the anatomical structures where water, oxygen, carbon dioxide and other nutrients are exchanged between blood and adjacent tissues. Therefore, their damage or degeneration seriously affects tissue homeostasis. Moreover, capillary engineering is of crucial importance while implanting tissue grafts, where new a vascular network must be developed within the implant [71]. Cell/biomaterial constructs described above for blood vessel engineering cannot easily be scaled down to build capillaries. The main reason for that is the size of these structures $(5-10 \mu \mathrm{m})$, the way they are built (single cell layer) and their unique properties concerning permeability. Furthermore, to work properly, capillary networks have to provide a level of spatial complexity adequate for the needs of the tissue in question. Blood vessels must be within 150-200 $\mu \mathrm{m}$ from metabolically active cells in order to provide sufficient oxygen and nutrient level 72,73 . A major challenge in tissue engineering is to achieve microcirculation rapidly after implantation in order to prevent cell starvation and death. There are two main physiological approaches to induce vascular networks within tissues: vasculogenesis and angiogenesis.

\subsubsection{Vasculogenesis and angiogenesis}

Blood vessels can arise through the aggregation of angioblasts into a vascular plexus. This process is called vasculogenesis and is dominant during embryogenesis. Recent studies demonstrate that vasculogenesis can also occur in adults, when endothelial progenitor and bone marrow-derived cells are recruited $[74$. Alternatively, angiogenesis is the formation of new vessels by sprouting of existing capillaries and is dominant post-natally 75. Being able to control and direct both processes opens the possibility to create capillary networks both within tissues as well as in in vitro engineered constructs.

Initially, most studies on angiogenesis were aimed to stop this process, e.g. to control tumor growth $[76$. However, information about growth factors and cytokines capable of inducing physiological blood vessel formation has been used to achieve the reverse goal. The possibility of inducing vasculogenesis or angiogenesis within tissues was first tested with the simple injection of pro-angiogenic growth factors such as basic fibroblast growth factor (FGF-2) and vascular endothelial growth factor (VEGF) 77, 78. It was quickly recognized that this method is expensive and not very efficient due to the high concentration of growth factors required. Following on this concept however, materials were chemically and mechanically tailored to transport and release bioactive molecules. In particular, hydrogels and synthetic polymer-based 
scaffolds, within which growth factors can be entrapped, are widely investigated for this purpose [79 81]. Richardson et al. demonstrated that dual delivery of VEGF and platelet-derived growth factor (PDGF), each with distinct kinetics, resulted in the rapid formation of a mature vascular network 82].

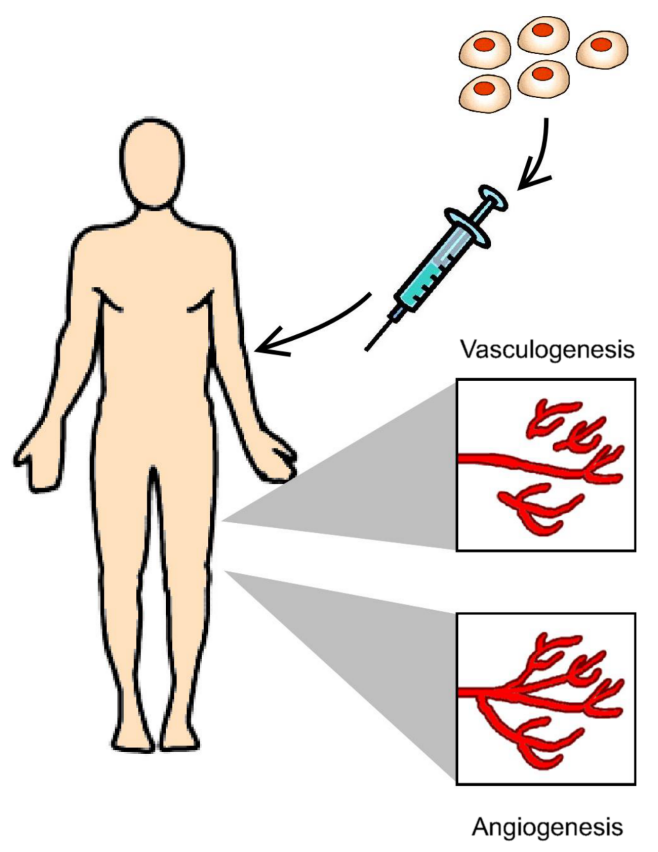

Figure 2.2: Cell therapy for neovascularization. De-novo vessel formation via self-organization into vessels or via induction of angiogenesis.

Another approach to controlled drug delivery into ischemic tissues is based on the concept of "living factories". The transplanted cells can either create new vessels de novo or attract vessel in-growth sending pro-angiogenic signals (Figure 2.2). Several cell types are able to produce growth factors and cytokines that improve angiogenesis in the place of delivery. Cells such as EPCs [83 85 or MSCs [86 were injected directly in the place of damage or systemically in a large vessel. The assumption was that the cells would reach the destination with blood flow. Those treatments showed limited improvement of the vessel network but the results were used as proof of principle and fueled further research in this area.

One possibility that offers good perspectives in improving abovementioned methods and making them clinically relevant is to precondition MSCs such that they secrete more pro-angiogenic factors. For instance, MSCs under hypoxic conditions secrete more VEGF [87, 88. Moreover, it was shown recently that the same subset of hypoxia-induced genes can be activated in hMSCs by exposing them to small molecules treatment which mimic the hypoxia pathway 89,90 . The added benefit 
of the small molecule approach is that controlled release strategies can be devised to enhance angiogenesis in vivo. For instance, we have recently shown that treatment of MSCs with the small molecule phenanthroline results not only in enhanced VEGF secretion but also enhanced vessel formation in vivo 91 .

MSCs and other stem and progenitor cells can also directly contribute to creating a capillary network through vasculogensis. Levenberg et al. described the induction of capillary networks in engineered tissue constructs using a three-dimensional system consisting of myoblasts, embryonic fibroblasts and endothelial cells co-seeded on porous polymer scaffolds 92 . They showed that induction and stabilization of the vessels in vitro improved the survival and vascularization of the engineered implants in vivo. Liu et al. showed that implantation of MSC-derived ECs results in vascularized collagen plugs and that MSC-derived ECs were incorporated in the vessel walls 93]. Based on these studies we investigated whether endothelial-like MSCs could replace embryonic fibroblasts and endothelial cells while maintaining their functionality. We observed that endothelial-like MSCs express endothelial markers and are incorporated in neo-vessel walls, while significantly increasing the capillary network in implanted constructs (Figure 2.3) 43.

A

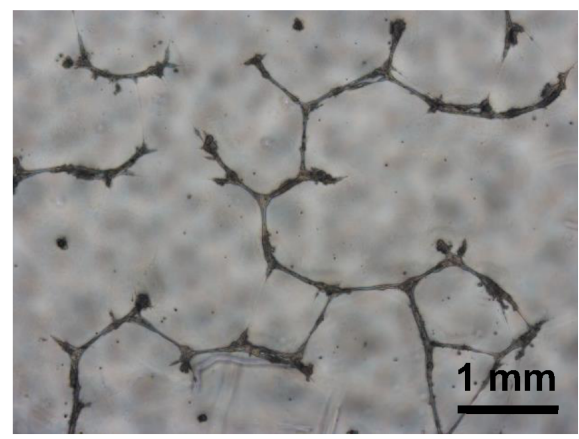

B

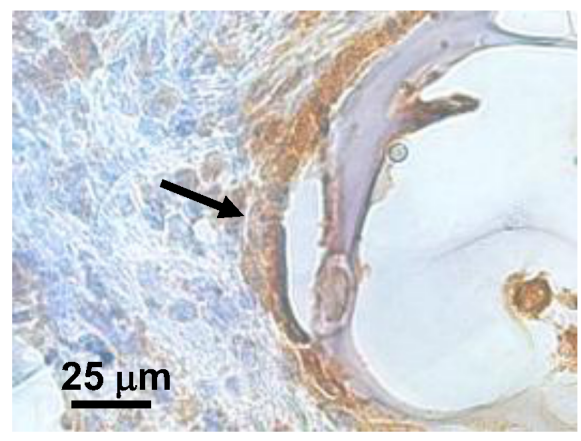

Figure 2.3: Endothelial-like MSCs in tissue engineering. Endotheliallike MSCs form capillary like structures on Matrigel (A) and express CD31 marker when implanted in vivo (B). For Matrigel assay cells were seeded and cultured for 24 hours before picture acquisition [43. In vivo data were obtained 6 weeks after implantation, cells were seeded within dextran-based hydrogels 94. Immunohistochemistry was used to stain for human CD31. CD31 positive cells are brown, CD31 positive lumen is indicated by black arrow.

To prevent cell migration from the place of delivery and provide efficient therapeutic influence, the strategy of delivering cells is of crucial importance. Modular tissue engineering 95, 96] allows us to combine hydrogels with growth factors and cells in order to create ready-to-use channels for in-growing capillaries upon implantation. This approach allows us to modulate the cell environment and by doing so 
boosts tissue vascularization. We have shown recently that modular tissue engineering is suitable for applications including endothelial-like MSCs allowing us to combine a novel three-dimensional approach with clinically relevant cell types 97 .

However, despite all the proof of principle described above, the ability to create a stable vascular network that can offer functionality to an ischemic organ or tissue implant remains a major challenge. The focus of research in this area should move to validate that the engineered strategies are functionally beneficial in vivo. As in the case of large vessel engineering, also for capillaries engineering, long-term studies are necessary to prove their safety and stability. The research and clinical trials described herein contribute to the broad set of clinical applications in the field of vascular tissue engineering. In addition, the cost of therapies that are currently based on complicated protocols including extensive scaffold material processing combined with the need for various cell types required to build functional vessels is a crucial issue that remains to be addressed. Thus, there are two main challenges for vascular researchers: first, to provide techniques that will allow for fast and efficient tissue engineering of vessels and capillaries and second, to establish the bridge between science and the market, allowing for introduction of vascular engineering into clinic. 


\subsection{Bibliography}

[1] J. A. Rhodin. Ultrastructure of mammalian venous capillaries, venules, and small collecting veins. J Ultrastruct Res, 25(5):452-500, 1968.

[2] Joshua I. Greenberg, David J. Shields, Samuel G. Barillas, Lisette M. Acevedo, Eric Murphy, Jianhua Huang, Lea Scheppke, Christian Stockmann, Randall S. Johnson, Niren Angle, and David A. Cheresh. A role for vegf as a negative regulator of pericyte function and vessel maturation. Nature, 456(7223):809-813, 2008.

[3] G. Bergers and S. Song. The role of pericytes in blood-vessel formation and maintenance. Neuro Oncol, 7(4):452-64, 2005.

[4] S. Paquet-Fifield, H. Schluter, A. Li, T. Aitken, P. Gangatirkar, D. Blashki, R. Koelmeyer, N. Pouliot, M. Palatsides, S. Ellis, N. Brouard, A. Zannettino, N. Saunders, N. Thompson, J. Li, and P. Kaur. A role for pericytes as microenvironmental regulators of human skin tissue regeneration. J Clin Invest, 119(9):2795-806, 2009.

[5] M. J. Doherty, B. A. Ashton, S. Walsh, J. N. Beresford, M. E. Grant, and A. E. Canfield. Vascular pericytes express osteogenic potential in vitro and in vivo. $J$ Bone Miner Res, 13(5):828-38, 1998.

[6] R. K. Jain. Molecular regulation of vessel maturation. Nat Med, 9(6):685-93, 2003.

[7] Norrving B Mendis S, Puska P. Global Atlas on Cardiovascular Disease Prevention and Control. World Health Organization, Geneva, 2011.

[8] Stefan Kiechl, Johann Willeit, and for the Bruneck Study Group. The natural course of atherosclerosis: Part ii: Vascular remodeling. Arteriosclerosis, Thrombosis, and Vascular Biology, 19(6):1491-1498, 1999.

[9] D. H. Gordon, S. Glanz, K. M. Butt, R. J. Adamsons, and M. A. Koenig. Treatment of stenotic lesions in dialysis access fistulas and shunts by transluminal angioplasty. Radiology, 143(1):53-8, 1982.

[10] R. D. Sayers, S. Raptis, M. Berce, and J. H. Miller. Long-term results of femorotibial bypass with vein or polytetrafluoroethylene. Br J Surg, 85(7):934-8, 1998.

[11] M. Gaudino, C. Cellini, C. Pragliola, C. Trani, F. Burzotta, G. Schiavoni, G. Nasso, and G. Possati. Arterial versus venous bypass grafts in patients with in-stent restenosis. Circulation, 112(9 Suppl):I265-9, 2005.

[12] Ruben Y. Kannan, Henryk J. Salacinski, Kevin Sales, Peter Butler, and Alexander M. Seifalian. The roles of tissue engineering and vascularisation in the development of micro-vascular networks: a review. Biomaterials, 26(14):1857-1875, 2005. 
[13] Stephen F. Badylak, Daniel J. Weiss, Arthur Caplan, and Paolo Macchiarini. Engineered whole organs and complex tissues. The Lancet, 379(9819):943-952, 2012.

[14] Anthony Atala, Stuart B. Bauer, Shay Soker, James J. Yoo, and Alan B. Retik. Tissue-engineered autologous bladders for patients needing cystoplasty. The Lancet, 367(9518):1241-1246, 2006.

[15] Dorothy M. Supp and Steven T. Boyce. Engineered skin substitutes: practices and potentials. Clinics in Dermatology, 23(4):403-412, 2005.

[16] N. L'Heureux, N. Dusserre, G. Konig, B. Victor, P. Keire, T. N. Wight, N. A. Chronos, A. E. Kyles, C. R. Gregory, G. Hoyt, R. C. Robbins, and T. N. McAllister. Human tissue-engineered blood vessels for adult arterial revascularization. Nat Med, 12(3):361-5, 2006.

[17] Gary K. Owens, Meena S. Kumar, and Brian R. Wamhoff. Molecular regulation of vascular smooth muscle cell differentiation in development and disease. Physiological Reviews, 84(3):767-801, 2004.

[18] Mihail Hristov, Wolfgang Erl, and Peter C. Weber. Endothelial progenitor cells: Mobilization, differentiation, and homing. Arteriosclerosis, Thrombosis, and Vascular Biology, 23(7):1185-1189, 2003.

[19] R. N. Salomon, C. C. Hughes, F. J. Schoen, D. D. Payne, J. S. Pober, and P. Libby. Human coronary transplantation-associated arteriosclerosis. evidence for a chronic immune reaction to activated graft endothelial cells. Am J Pathol, 138(4):791-8, 1991.

[20] R. M. Nerem and D. Seliktar. Vascular tissue engineering. Annu Rev Biomed Eng, 3:225-43, 2001.

[21] M. K. Hagensen, P. M. Vanhoutte, and J. F. Bentzon. Arterial endothelial cells: still the craftsmen of regenerated endothelium. Cardiovasc Res, 95(3):281-9, 2012 .

[22] M. C. Yoder. Human endothelial progenitor cells. Cold Spring Harb Perspect Med, 2(7):a006692, 2012.

[23] David Simper, Paul G. Stalboerger, Carmelo J. Panetta, Shaohua Wang, and Noel M. Caplice. Smooth muscle progenitor cells in human blood. Circulation, 106(10):1199-1204, 2002.

[24] Yuji Kashiwakura, Youichi Katoh, Kenji Tamayose, Hakuoh Konishi, Norihide Takaya, Senji Yuhara, Masanori Yamada, Koichi Sugimoto, and Hiroyuki Daida. Isolation of bone marrow stromal cell-derived smooth muscle cells by a human sm $22 \alpha$ promoter: In vitro differentiation of putative smooth muscle progenitor cells of bone marrow. Circulation, 107(16):2078-2081, 2003. 
[25] Takayuki Asahara, Toyoaki Murohara, Alison Sullivan, Marcy Silver, Rien van der Zee, Tong Li, Bernhard Witzenbichler, Gina Schatteman, and Jeffrey M. Isner. Isolation of putative progenitor endothelial cells for angiogenesis. Science, 275(5302):964-966, 1997.

[26] D. A. Ingram, L. E. Mead, H. Tanaka, V. Meade, A. Fenoglio, K. Mortell, K. Pollok, M. J. Ferkowicz, D. Gilley, and M. C. Yoder. Identification of a novel hierarchy of endothelial progenitor cells using human peripheral and umbilical cord blood. Blood, 104(9):2752-60, 2004.

[27] D. P. Griese, A. Ehsan, L. G. Melo, D. Kong, L. Zhang, M. J. Mann, R. E. Pratt, R. C. Mulligan, and V. J. Dzau. Isolation and transplantation of autologous circulating endothelial cells into denuded vessels and prosthetic grafts: implications for cell-based vascular therapy. Circulation, 108(21):2710-5, 2003.

[28] S. Kaushal, G. E. Amiel, K. J. Guleserian, O. M. Shapira, T. Perry, F. W. Sutherland, E. Rabkin, A. M. Moran, F. J. Schoen, A. Atala, S. Soker, J. Bischoff, and Jr. Mayer, J. E. Functional small-diameter neovessels created using endothelial progenitor cells expanded ex vivo. Nat Med, 7(9):1035-40, 2001.

[29] T. Shirota, H. He, H. Yasui, and T. Matsuda. Human endothelial progenitor cell-seeded hybrid graft: proliferative and antithrombogenic potentials in vitro and fabrication processing. Tissue Eng, 9(1):127-36, 2003.

[30] G. Krenning, M. J. van Luyn, and M. C. Harmsen. Endothelial progenitor cellbased neovascularization: implications for therapy. Trends Mol Med, 15(4):180-9, 2009.

[31] E. R. Popa, M. C. Harmsen, R. A. Tio, B. W. van der Strate, L. A. Brouwer, M. Schipper, J. Koerts, M. J. De Jongste, A. Hazenberg, M. Hendriks, and M. J. van Luyn. Circulating cd34+ progenitor cells modulate host angiogenesis and inflammation in vivo. J Mol Cell Cardiol, 41(1):86-96, 2006.

[32] J. Rouwkema, P. E. Westerweel, J. de Boer, M. C. Verhaar, and C. A. van Blitterswijk. The use of endothelial progenitor cells for prevascularized bone tissue engineering. Tissue Eng Part A, 15(8):2015-27, 2009.

[33] N. Krankel, R. G. Katare, M. Siragusa, L. S. Barcelos, P. Campagnolo, G. Mangialardi, O. Fortunato, G. Spinetti, N. Tran, K. Zacharowski, W. Wojakowski, I. Mroz, A. Herman, J. E. Manning Fox, P. E. MacDonald, J. P. Schanstra, J. L. Bascands, R. Ascione, G. Angelini, C. Emanueli, and P. Madeddu. Role of kinin $\mathrm{b} 2$ receptor signaling in the recruitment of circulating progenitor cells with neovascularization potential. Circ Res, 103(11):1335-43, 2008.

[34] Tatyana Merkulova-Rainon, Dong Broquères-You, Nathalie Kubis, JeanSébastien Silvestre, and Bernard I. Lévy. Towards the therapeutic use of vascular smooth muscle progenitor cells. Cardiovascular Research, 95(2):205-214, 2012. 
[35] Lindolfo da Silva Meirelles, Pedro Cesar Chagastelles, and Nance Beyer Nardi. Mesenchymal stem cells reside in virtually all post-natal organs and tissues. Journal of Cell Science, 119(11):2204-2213, 2006.

[36] M. C. Galmiche, V. E. Koteliansky, J. Briere, P. Herve, and P. Charbord. Stromal cells from human long-term marrow cultures are mesenchymal cells that differentiate following a vascular smooth muscle differentiation pathway. Blood, 82(1):66-76, 1993.

[37] Patrick Au, Joshua Tam, Dai Fukumura, and Rakesh K. Jain. Bone marrow-derived mesenchymal stem cells facilitate engineering of long-lasting functional vasculature. Blood, 111(9):4551-4558, 2008.

[38] J. M. Melero-Martin, Z. A. Khan, A. Picard, X. Wu, S. Paruchuri, and J. Bischoff. In vivo vasculogenic potential of human blood-derived endothelial progenitor cells. Blood, 109(11):4761-8, 2007.

[39] J. Oswald, S. Boxberger, B. Jorgensen, S. Feldmann, G. Ehninger, M. Bornhauser, and C. Werner. Mesenchymal stem cells can be differentiated into endothelial cells in vitro. Stem Cells, 22(3):377-84, 2004.

[40] L. J. Fischer, S. McIlhenny, T. Tulenko, N. Golesorkhi, P. Zhang, R. Larson, J. Lombardi, I. Shapiro, and P. J. DiMuzio. Endothelial differentiation of adiposederived stem cells: effects of endothelial cell growth supplement and shear force. J Surg Res, 152(1):157-66, 2009.

[41] P. Zhang, J. Baxter, K. Vinod, T. N. Tulenko, and P. J. Di Muzio. Endothelial differentiation of amniotic fluid-derived stem cells: synergism of biochemical and shear force stimuli. Stem Cells Dev, 18(9):1299-308, 2009.

[42] Y. Cao, Z. Sun, L. Liao, Y. Meng, Q. Han, and R. C. Zhao. Human adipose tissue-derived stem cells differentiate into endothelial cells in vitro and improve postnatal neovascularization in vivo. Biochem Biophys Res Commun, 332(2):3709, 2005.

[43] K. Janeczek Portalska, A. Leferink, N. Groen, H. Fernandes, L. Moroni, C. van Blitterswijk, and J. de Boer. Endothelial differentiation of mesenchymal stromal cells. PLoS One, 7(10):e46842, 2012.

[44] J. Rouwkema, N. C. Rivron, N. M. S. Bettahalli, D. Stamatialis, M. Wessling, and C. A. van Blitterswijk. Mesenchymal stem cells differentiate towards endothelial cells in a prevascularized bone tissue engineering setting. Tissue Eng Part A, 01 2008 .

[45] S. Levenberg, J. S. Golub, M. Amit, J. Itskovitz-Eldor, and R. Langer. Endothelial cells derived from human embryonic stem cells. Proc Natl Acad Sci U S A, 99(7):4391-6, 2002. 
[46] J. Kim, S. H. Moon, S. H. Lee, D. R. Lee, G. Y. Koh, and H. M. Chung. Effective isolation and culture of endothelial cells in embryoid body differentiated from human embryonic stem cells. Stem Cells Dev, 16(2):269-80, 2007.

[47] Jeannette Nussbaum, Elina Minami, Michael A. Laflamme, Jitka A. I. Virag, Carol B. Ware, Amanda Masino, Veronica Muskheli, Lil Pabon, Hans Reinecke, and Charles E. Murry. Transplantation of undifferentiated murine embryonic stem cells in the heart: teratoma formation and immune response. The FASEB Journal, 21(7):1345-1357, 2007.

[48] Takahisa Fujikawa, Seh-Hoon Oh, Liya Pi, Heather M. Hatch, Tom Shupe, and Bryon E. Petersen. Teratoma formation leads to failure of treatment for type i diabetes using embryonic stem cell-derived insulin-producing cells. The American journal of pathology, 166(6):1781-1791, 2005.

[49] K. D. Choi, J. Yu, K. Smuga-Otto, G. Salvagiotto, W. Rehrauer, M. Vodyanik, J. Thomson, and I. Slukvin. Hematopoietic and endothelial differentiation of human induced pluripotent stem cells. Stem Cells, 27(3):559-67, 2009.

[50] Tarjei S. Mikkelsen, Jacob Hanna, Xiaolan Zhang, Manching Ku, Marius Wernig, Patrick Schorderet, Bradley E. Bernstein, Rudolf Jaenisch, Eric S. Lander, and Alexander Meissner. Dissecting direct reprogramming through integrative genomic analysis. Nature, 454(7200):49-55, 2008.

[51] Kathrin Plath and William E. Lowry. Progress in understanding reprogramming to the induced pluripotent state. Nat Rev Genet, 12(4):253-265, 2011.

[52] A. Margariti, B. Winkler, E. Karamariti, A. Zampetaki, T. N. Tsai, D. Baban, J. Ragoussis, Y. Huang, J. D. Han, L. Zeng, Y. Hu, and Q. Xu. Direct reprogramming of fibroblasts into endothelial cells capable of angiogenesis and reendothelialization in tissue-engineered vessels. Proc Natl Acad Sci USA, 109(34):13793-8, 2012.

[53] M. Ginsberg, D. James, B. S. Ding, D. Nolan, F. Geng, J. M. Butler, W. Schachterle, V. R. Pulijaal, S. Mathew, S. T. Chasen, J. Xiang, Z. Rosenwaks, K. Shido, O. Elemento, S. Y. Rabbany, and S. Rafii. Efficient direct reprogramming of mature amniotic cells into endothelial cells by ets factors and tgfbeta suppression. Cell, 151(3):559-75, 2012.

[54] Buddy D. Ratner and Stephanie J. Bryant. Biomaterials: Where we have been and where we are going. Annu Rev Biomed Eng, 6(1):41-75, 2004.

[55] E. A. Phelps, N. Landazuri, P. M. Thule, W. R. Taylor, and A. J. Garcia. Bioartificial matrices for therapeutic vascularization. Proc Natl Acad Sci US A, 107(8):3323-8, 2010.

[56] H. Bae, A. S. Puranik, R. Gauvin, F. Edalat, B. Carrillo-Conde, N. A. Peppas, and A. Khademhosseini. Building vascular networks. Sci Transl Med, 4(160):160ps23, 2012. 
[57] Stephen F. Badylak, Doris Taylor, and Korkut Uygun. Whole-organ tissue engineering: Decellularization and recellularization of three-dimensional matrix scaffolds. Annu Rev Biomed Eng, 13(1):27-53, 2011.

[58] Brett C. Isenberg and Joyce Y. Wong. Building structure into engineered tissues. Materials Today, 9(12):54-60, 2006.

[59] S. L. Dahl, J. Koh, V. Prabhakar, and L. E. Niklason. Decellularized native and engineered arterial scaffolds for transplantation. Cell Transplant, 12(6):659-66, 2003.

[60] N. Dahan, G. Zarbiv, U. Sarig, T. Karram, A. Hoffman, and M. Machluf. Porcine small diameter arterial extracellular matrix supports endothelium formation and media remodeling forming a promising vascular engineered biograft. Tissue Eng Part A, 18(3-4):411-22, 2012.

[61] P. J. Schaner, N. D. Martin, T. N. Tulenko, I. M. Shapiro, N. A. Tarola, R. F. Leichter, R. A. Carabasi, and P. J. Dimuzio. Decellularized vein as a potential scaffold for vascular tissue engineering. J Vasc Surg, 40(1):146-53, 2004.

[62] C. L. Cummings, D. Gawlitta, R. M. Nerem, and J. P. Stegemann. Properties of engineered vascular constructs made from collagen, fibrin, and collagen-fibrin mixtures. Biomaterials, 25(17):3699-706, 2004.

[63] S. A. Sell, M. J. McClure, K. Garg, P. S. Wolfe, and G. L. Bowlin. Electrospinning of collagen/biopolymers for regenerative medicine and cardiovascular tissue engineering. Adv Drug Deliv Rev, 61(12):1007-19, 2009.

[64] L. Buttafoco, N. G. Kolkman, P. Engbers-Buijtenhuijs, A. A. Poot, P. J. Dijkstra, I. Vermes, and J. Feijen. Electrospinning of collagen and elastin for tissue engineering applications. Biomaterials, 27(5):724-34, 2006.

[65] J. D. Berglund, R. M. Nerem, and A. Sambanis. Incorporation of intact elastin scaffolds in tissue-engineered collagen-based vascular grafts. Tissue Eng, 10(910):1526-35, 2004.

[66] Michael Lovett, Christopher Cannizzaro, Laurence Daheron, Brady Messmer, Gordana Vunjak-Novakovic, and David L. Kaplan. Silk fibroin microtubes for blood vessel engineering. Biomaterials, 28(35):5271-5279, 2007.

[67] C. Y. Xu, R. Inai, M. Kotaki, and S. Ramakrishna. Aligned biodegradable nanofibrous structure: a potential scaffold for blood vessel engineering. Biomaterials, 25(5):877-886, 2004.

[68] W. He, T. Yong, W. E. Teo, Z. Ma, and S. Ramakrishna. Fabrication and endothelialization of collagen-blended biodegradable polymer nanofibers: potential vascular graft for blood vessel tissue engineering. Tissue Eng, 11(9-10):1574-88, 2005. 
[69] Z. Ma, M. Kotaki, T. Yong, W. He, and S. Ramakrishna. Surface engineering of electrospun polyethylene terephthalate (pet) nanofibers towards development of a new material for blood vessel engineering. Biomaterials, 26(15):2527-36, 2005.

[70] N. L'Heureux, S. Paquet, R. Labbe, L. Germain, and F. A. Auger. A completely biological tissue-engineered human blood vessel. FASEB J, 12(1):47-56, 1998.

[71] N. C. Rivron, J. J. Liu, J. Rouwkema, J. de Boer, and C. A. van Blitterswijk. Engineering vascularised tissues in vitro. Eur Cell Mater, 15:27-40, 2008.

[72] C. K. Colton. Implantable biohybrid artificial organs. Cell Transplant, 4(4):41536, 1995.

[73] A. Zumstein, O. Mathieu, H. Howald, and H. Hoppeler. Morphometric analysis of the capillary supply in skeletal muscles of trained and untrained subjects-its limitations in muscle biopsies. Pflugers Arch, 397(4):277-83, 1983.

[74] Oren M. Tepper, Jennifer M. Capla, Robert D. Galiano, Daniel J. Ceradini, Matthew J. Callaghan, Mark E. Kleinman, and Geoffrey C. Gurtner. Adult vasculogenesis occurs through in situ recruitment, proliferation, and tubulization of circulating bone marrow-derived cells. Blood, 105(3):1068-1077, 2005.

[75] Thomas J. Poole and J. Douglas Coffin. Vasculogenesis and angiogenesis: Two distinct morphogenetic mechanisms establish embryonic vascular pattern. Journal of Experimental Zoology, 251(2):224-231, 1989.

[76] P. Carmeliet and R. K. Jain. Angiogenesis in cancer and other diseases. Nature, 407(6801):249-57, 2000.

[77] Roger J. Laham, Nicholas A. Chronos, Marilyn Pike, Mark E. Leimbach, James E. Udelson, Justin D. Pearlman, Roderic I. Pettigrew, M. J. Whitehouse, Carl Yoshizawa, and Michael Simons. Intracoronary basic fibroblast growth factor (fgf-2) in patients with severe ischemic heart disease: results of a phase i open-label dose escalation study. J Am Coll Cardiol, 36(7):2132-2139, 2000.

[78] Douglas W. Losordo, Peter R. Vale, Robert C. Hendel, Charles E. Milliken, F. David Fortuin, Nancie Cummings, Richard A. Schatz, Takayuki Asahara, Jeffrey M. Isner, and Richard E. Kuntz. Phase 1/2 placebo-controlled, doubleblind, dose-escalating trial of myocardial vascular endothelial growth factor 2 gene transfer by catheter delivery in patients with chronic myocardial ischemia. Circulation, 105(17):2012-2018, 2002.

[79] Anat Perets, Yaacov Baruch, Felix Weisbuch, Gideon Shoshany, Gera Neufeld, and Smadar Cohen. Enhancing the vascularization of three-dimensional porous alginate scaffolds by incorporating controlled release basic fibroblast growth factor microspheres. Journal of Biomedical Materials Research Part A, 65A(4):489497, 2003. 
[80] Yasuhiko Tabata, Manabu Miyao, Masaya Yamamoto, and Yoshito Ikada. Vascularization into a porous sponge by sustained release of basic fibroblast growth factor. Journal of Biomaterials Science, Polymer Edition, 10(9):957-968, 1999.

[81] Yasuhiko Tabata, Manabu Miyao, Makoto Ozeki, and Yoshito Ikada. Controlled release of vascular endothelial growth factor by use of collagen hydrogels. Journal of Biomaterials Science, Polymer Edition, 11(9):915-930, 2000.

[82] T. P. Richardson, M. C. Peters, A. B. Ennett, and D. J. Mooney. Polymeric system for dual growth factor delivery. Nat Biotechnol, 19(11):1029-34, 2001.

[83] H. S. Hung, W. C. Shyu, C. H. Tsai, S. H. Hsu, and S. Z. Lin. Transplantation of endothelial progenitor cells as therapeutics for cardiovascular diseases. Cell Transplant, 18(9):1003-12, 2009.

[84] Osamu Iba, Hiroaki Matsubara, Yoshihisa Nozawa, Soichiro Fujiyama, Katsuya Amano, Yasukiyo Mori, Hiroyuki Kojima, and Toshiji Iwasaka. Angiogenesis by implantation of peripheral blood mononuclear cells and platelets into ischemic limbs. Circulation, 106(15):2019-2025, 2002.

[85] Atsuhiko Kawamoto, Tengis Tkebuchava, Jun-Ichi Yamaguchi, Hiromi Nishimura, Young-Sup Yoon, Charles Milliken, Shigeki Uchida, Osamu Masuo, Hideki Iwaguro, Hong Ma, Allison Hanley, Marcy Silver, Marianne Kearney, Douglas W. Losordo, Jeffrey M. Isner, and Takayuki Asahara. Intramyocardial transplantation of autologous endothelial progenitor cells for therapeutic neovascularization of myocardial ischemia. Circulation, 107(3):461-468, 2003.

[86] H. Kamihata, H. Matsubara, T. Nishiue, S. Fujiyama, Y. Tsutsumi, R. Ozono, H. Masaki, Y. Mori, O. Iba, E. Tateishi, A. Kosaki, S. Shintani, T. Murohara, T. Imaizumi, and T. Iwasaka. Implantation of bone marrow mononuclear cells into ischemic myocardium enhances collateral perfusion and regional function via side supply of angioblasts, angiogenic ligands, and cytokines. Circulation, 104(9):1046-52, 2001.

[87] X. Hu, S. P. Yu, J. L. Fraser, Z. Lu, M. E. Ogle, J. A. Wang, and L. Wei. Transplantation of hypoxia-preconditioned mesenchymal stem cells improves infarcted heart function via enhanced survival of implanted cells and angiogenesis. J Thorac Cardiovasc Surg, 135(4):799-808, 2008.

[88] S. C. Hung, R. R. Pochampally, S. C. Chen, S. C. Hsu, and D. J. Prockop. Angiogenic effects of human multipotent stromal cell conditioned medium activate the pi3k-akt pathway in hypoxic endothelial cells to inhibit apoptosis, increase survival, and stimulate angiogenesis. Stem Cells, 25(9):2363-70, 2007.

[89] Chao Wan, Shawn R. Gilbert, Ying Wang, Xuemei Cao, Xing Shen, Girish Ramaswamy, Kimberly A. Jacobsen, Zainab S. Alaql, Alan W. Eberhardt, Louis C. Gerstenfeld, Thomas A. Einhorn, Lianfu Deng, and Thomas L. Clemens. Activation of the hypoxia-inducible factor- $1 \alpha$ pathway accelerates bone regeneration. Proceedings of the National Academy of Sciences, 105(2):686-691, 2008. 
[90] J. Doorn, H. A. Fernandes, B. Q. Le, J. van de Peppel, J. P. van Leeuwen, M. R. De Vries, Z. Aref, P. H. Quax, O. Myklebost, D. B. Saris, C. A. van Blitterswijk, and J. de Boer. A small molecule approach to engineering vascularized tissue. Biomaterials, 34(12):3053-63, 2013.

[91] J. Doorn, R. Siddappa, C. van Blitterswijk, and J. De Boer. Forskolin enhances in vivo bone formation by human mesenchymal stromal cells. Tissue Eng Part A, 2011.

[92] S. Levenberg, J. Rouwkema, M. Macdonald, E. S. Garfein, D. S. Kohane, D. C. Darland, R. Marini, C. A. van Blitterswijk, R. C. Mulligan, P. A. D'Amore, and R. Langer. Engineering vascularized skeletal muscle tissue. Nat Biotechnol, 23(7):879-84, 2005.

[93] J. W. Liu, S. Dunoyer-Geindre, V. Serre-Beinier, G. Mai, J. F. Lambert, R. J. Fish, G. Pernod, L. Buehler, H. Bounameaux, and E. K. Kruithof. Characterization of endothelial-like cells derived from human mesenchymal stem cells. $J$ Thromb Haemost, 5(4):826-34, 2007.

[94] K. J. Portalska, L. M. Teixeira, J. C. Leijten, R. Jin, C. van Blitterswijk, J. de Boer, and M. Karperien. Boosting angiogenesis and functional vascularization in injectable dextran-hyaluronic acid hydrogels by endothelial-like mesenchymal stromal cells. Tissue Eng Part A, 2013.

[95] J. W. Nichol and A. Khademhosseini. Modular tissue engineering: Engineering biological tissues from the bottom up. Soft Matter, 5(7):1312-1319, 2009.

[96] A. P. McGuigan and M. V. Sefton. Vascularized organoid engineered by modular assembly enables blood perfusion. Proc Natl Acad Sci U S A, 103(31):11461-6, 2006.

[97] K. J. Portalska, M. Dean Chamberlain, C. Lo, C. van Blitterswijk, M. V. Sefton, and J. de Boer. Collagen modules for in situ delivery of mesenchymal stromal cell-derived endothelial cells for improved angiogenesis. J Tissue Eng Regen Med, 2013. 



\title{
Chapter 3
}

\section{Endothelial differentiation of mesenchymal stromal cells}

Karolina Janeczek Portalska, Anne Leferink, Nathalie Groen, Hugo Fernandes, Lorenzo Moroni, Clemens van Blitterswijk and Jan de Boer

\begin{abstract}
Human mesenchymal stromal cells (hMSCs) are increasingly used in regenerative medicine for restoring worn-out or damaged tissue. Newly engineered tissues need to be properly vascularized and current candidates for in vitro tissue pre-vascularization are endothelial cells and endothelial progenitor cells. However, their use in therapy is hampered by their limited expansion capacity and lack of autologous sources. Our approach to engineering large grafts is to use hMSCs both as a source of cells for regeneration of targeted tissue and at the same time as the source of endothelial cells. Here we investigate how different stimuli influence endothelial differentiation of hMSCs. Although growth supplements together with shear force were not sufficient to differentiate hMSCs with respect to expression of endothelial markers such as CD31 and KDR, these conditions did prime the cells to differentiate into cells with an endothelial gene expression profile and morphology when seeded on Matrigel. In addition, we show that endothelial-like hMSCs are able to create a capillary network in $3 \mathrm{D}$ culture both in vitro and in vivo conditions. The expansion phase in the presence of growth supplements was crucial for the stability of the capillaries formed in vitro. To conclude, we established a robust protocol for endothelial differentiation of hMSCs, including an immortalized MSC line (iMSCs) which allows for reproducible in vitro analysis in further studies.
\end{abstract}

\subsection{Introduction}

Human mesenchymal stromal cells (hMSCs), also referred to as colony forming unitfibroblasts (CFU-F), mesenchymal stem cells, or mesenchymal progenitor cells were 
first identified as a subpopulation of bone marrow cells by Friedenstein [1]. Their abundance among other bone marrow cells was estimated to be $0.01 \%$ to $0.001 \%[1]$. Later research showed that MSCs can be isolated from other types of tissues as well, including adipose tissue, placenta, periosteum, trabecular bone and femur [4 7$]$. MSCs can be characterized based on their fibroblast-like morphology and ability to differentiate into various cell type [8]. To induce adipogenic differentiation, stimulation with insulin, dexamethasone and IBMX is typically applied [9]. MSCs cultured in dexamethasone differentiate towards osteoblasts and can participate in new bone formation after implantation in critical size bone defects 10 12. TGF- $\beta$ stimulation, especially when combined with BMP-2 treatment, can trigger chondrogenic differentiation of MSCs 13. While MSC differentiation towards adipo-, osteo- and chondrogenic lineages is widely investigated, some studies have also shown that MSCs can differentiate towards muscular and neural phenotype, but those are less documented and the differentiation protocols are not yet widely applied. For instance, myoblasts can be obtained from MSCs after applying basic fibroblast growth factor (bFGF) and forskolin 14 16]. On the other hand, platelet-derived growth factor (PDGF) together with forskolin and glial growth factor (GGF-2) stimulation results in differentiation of MSCs into cells with a Schwann cell-like phenotype [17]. Continuous trials to obtain neural cells have resulted in several studies demonstrating the possibility of obtaining MSC-derived cells that can support the regeneration of nerves and participate among others in therapy of erectile dysfunction, multiple sclerosis and spinal cord injury 18, 19]. MSCs are also capable of suppressing allo-responses and appear to be non-immunogenic [20]. Therefore, hMSCs are increasingly used in regenerative medicine as a source of cells for restoring worn-out or damaged tissues such as cartilage, cardiac muscle or bone. In the field of bone tissue engineering there are a total of 9 human clinical trials performed to date 21]. Other clinical trials with MSCs are performed to improve cardiac functions after myocardial infarction $[22,23$ and to restore liver and kidney function after failure [24, 25].

The standard approach in regenerative medicine when MSCs are used is to identify the cell type necessary for the therapy and then differentiate MSCs towards this phenotype. Differentiated cells are then used in animal models and when the therapy is successful, clinical trials are performed. There is, however, a clear need for endothelial cells (EC) in this approach. ECs are needed to line artificial vessels and to restore vascularization of ischemic tissues. This is a crucial point in therapy of peripheral vascular diseases [26] which is a growing medical problem in Western societies and manifests itself in obstruction of large arteries. This leads to retraction of small arteries and capillaries followed by acute or chronic ischemia in surrounding tissues. Only the recovery of the vascular network in such tissues can restore blood flow and prevent limb amputation [27]. Another difficulty that may be solved by providing a good source of endothelial cells is the maintenance of cell survival after graft implantation. The key parameter in this problem is the supply of nutrients and oxygen in which diffusion is a limiting factor. Metabolically active cells must be situated within 150-200 $\mu \mathrm{m}$ distance from blood vessels in order to maintain proper functions 28, 29]. To maintain cell survival in large grafts, a vascular structure needs 
to be introduced within the graft which can rapidly connect to the host's blood vessels upon implantation. Without that, cell death and lack of new tissue formation in the interior of the implant will occur [30]. The proof of principle for the application of ECs in the abovementioned conditions has been achieved using endothelial progenitor cells (EPCs) 31 and endothelial cells. EPCs are immature cells capable of differentiating into mature endothelial cells in vitro and in vivo 32 . EPCs are cells with some selfrenewing capacity present both in the bone marrow and in circulation 33. Recently, the vasculogenic potential of different EPCs was investigated and compared [34, 35]. EPCs adhere to gelatin and fibronectin, take up acetylated LDL, bind lectins from Ulex Europaeus, and express marker proteins of the EC lineage (e.g. CD31, KDR, vWF). However, they either lose their potential after prolongated expansion or their expansion capacity is not enough to provide sufficient numbers of cells for therapeutic applications 36, 37. Mature ECs isolated from umbilical vein or aorta are considered as another cell source for graft vascularization 38. These cells can be expanded in vitro and perform well in creating vascular networks in vivo [39, 40]. Autologous isolation is however only possible by sacrificing a current vessel of the patient. Since bone marrow derived MSCs were shown to differentiate into adipogenic, osteogenic and chondrogenic lineages [41] they can also be considered as a promising source for obtaining endothelial cells that are able to create vascular networks. There are several factors reported to influence endothelial differentiation and maintain endothelial potential in vitro while using embryonic stem cells or EPCs. Specifically, the effects of endothelial growth supplements 42 44], shear forces [45 49 ] and composition of extracellular matrix [44,50] are important factors in EC culture. These factors influence the efficiency of capillary-like structure formation on Matrigel, endothelial markers expression (CD31, vWF, KDR), the ability to take up acetylated LDL and their in vivo performance. In the last 10 years, much effort was put into establishing protocols for endothelial differentiation of mesenchymal stromal cells. In particular, cells isolated form adipose tissue were reported to respond positively for endothelial differentiation [51, 52]. In the case of MSCs isolated form bone marrow (BM-MSCs) several studies were conducted with various outcomes. The work of Oswald et al. shows that BM-MSCs can acquire in vitro phenotypic and functional features of ECs [53]. Silva et al. demonstrated that MSCs injected into ischemic myocardium can differentiate into smooth muscle cells and endothelial cells in vivo, resulting in increased vascularity and improved cardiac functions [54]. Differentiation of MSCs into endothelial cells in vitro did not improve their performance in vivo [55], which could be due to a sub-optimal differentiation protocol, similar to previous attempts to improve ectopic bone formation by hMSCs. Only after precise adjustment of several parameters a protocol was obtained that resulted in an improvement in vivo [56. In this manuscript we demonstrate a robust and efficient endothelial differentiation protocol for MSCs, which describes the isolation, expansion and differentiation of BM-MSCs and their potential in tissue engineering as endothelial-like cells. 


\subsection{Materials and methods}

\subsubsection{Isolation and culture}

Human mesenchymal stromal cells (hMSCs) were isolated from human bone marrow from donors with written informed consent 57 . Aspirates were resuspended using a $20 \mathrm{G}$ needle and plated at a density of 0.5 million mono-nucleated cells per $\mathrm{cm}^{2}$. Cells were grown in MSC proliferation medium which contains minimal essential medium (alfa-MEM, GIBCO) supplemented with $10 \%$ fetal bovine serum (FBS, Lonza) , $100 \mathrm{U} / \mathrm{ml}$ penicillin (GIBCO), $10 \mu \mathrm{g} / \mathrm{ml}$ streptomycin (GIBCO), $2 \mathrm{mM}$ L-glutamin (GIBCO), $0.2 \mathrm{mM} \mathrm{L-ascorbic} \mathrm{acid} \mathrm{2-phosphate} \mathrm{magnesium} \mathrm{salt} \mathrm{(ASAp,}$ Sigma-Aldrich) and $1 \mathrm{ng} / \mathrm{ml}$ bFGF (Fisher Scientific) at $37^{\circ} \mathrm{C}$ in a humid atmosphere with $5 \% \mathrm{CO}_{2}$. Cells were expanded up to passage 2. For further experiments hMSCs from two different donors and one immortalized clone (iMSCs, courtesy of Ola Myklebost, University of Oslo, Norway) were cultured in basic medium (alfa-MEM supplemented with $10 \% \mathrm{FBS}, 100 \mathrm{U} / \mathrm{ml}$ penicillin, $10 \mu \mathrm{g} / \mathrm{ml}$ streptomycin, $2 \mathrm{mM}$ L-glutamin and $0.2 \mathrm{mM} \mathrm{ASAp).} \mathrm{Human} \mathrm{umbilical} \mathrm{vein} \mathrm{endothelial} \mathrm{cells} \mathrm{(HUVEC,}$ Lonza) were cultured in endothelial growth medium (EGM-2, Lonza). Mouse skeletal myoblast cells (C2C12) and mouse embryonic fibroblasts (MEF) (Cell Essentials) were cultured in Dulbecco's Modified Eagle's Medium (DMEM, GIBCO) supplemented with $10 \% \mathrm{FBS}, 100 \mathrm{U} / \mathrm{ml}$ penicillin and $10 \mu \mathrm{g} / \mathrm{ml}$ streptomycin.

\subsubsection{Endothelial induction of MSCs}

hMSCs from passage 2 and iMSCs from passage 25 were used for the endothelial induction protocol. Cells were seeded at a density of $3,000 \mathrm{cells} / \mathrm{cm}^{2}$ on tissue culture plastic in EGM-2 and cultured for 10 days. After one day in static culture shear force was applied using an XYZ shaker (3D shaker). Cultures were rotated at a rate of $20 \mathrm{rpm}$. Cells that were cultured according to this protocol will be referred to as pre-differentiated MSCs.

Phalloidin and DAPI stainings were used for cell size and shape analysis. Pictures were taken with a BD Pathway ${ }^{\mathrm{TM}}$ Bioimager and analyzed using Attovision software. A minimal number of 300 cells per condition were analyzed.

For induction on Matrigel, wells of 6-well plates were covered with $1 \mathrm{ml}$ of growth factor reduced Matrigel (BD Bioscience) diluted 1:1 in EGM-2 without growth factors. Cells were seeded at a density of 30,000 cells $/ \mathrm{cm}^{2}$ and cultured in a humid atmosphere with $5 \% \mathrm{CO}_{2}$ for 24 hours. The formation of capillary-like structures (CLS) was observed over time using an inverted microscope (Nikon Eclipse TE300). Pictures were taken at different time points using a Nikon DS-L2 camera.

\subsubsection{Wound healing assay}

iMSCs were cultured for 10 days in EGM-2 on an XYZ shaker and were then trypsinized and seeded in 6 -well plates at a density of 15,000 cells $/ \mathrm{cm}^{2}$. iMSCs expanded in basic 
medium were used as a negative control. After $24 \mathrm{~h}$ of culture, cells reached $90 \%$ confluency. The cell monolayers were gently scratched using a pipette tip across the entire diameter of the well. Cells were washed twice with PBS to remove cellular debris and then cultured in basic medium to avoid differential growth factor stimulation during the assay. The size of the wounds directly after making the scratch and following wound closure was observed over time using an inverted microscope (Nikon Eclipse TE300). Pictures were taken at each time-point using a NikonDS-L2 camera. The wound size was determined using TScratch software (CSElab) as percentage of the picture area that was not occupied by cells.

\subsubsection{TubeCount}

Custom image recognition and analysis software has been implemented in $\mathrm{C}++$ programming language with the aid of dlib library (http://dlib.net/) used for image processing and graphical user interface, Anti-Grain Geometry library (http: //www.antigrain.com/) as vector graphics engine and FFTW library (http://www . fftw.org/) for calculating Fourier transforms. The purpose of the software is to quantify tube formation efficiency which is performed in two stages. The first stage is a fully automated segmentation routine which partitions the image into background region (insignificant to further analysis) and foreground region (containing cells). Segmentation is based on the assumed characteristics of cell images obtained with phase contrast microscopy (Figure 3.1A) and primarily relies on the existence of well-defined cell edges and on low pixel intensity (dark shades) within the cells as compared to image background. To extract regions which fulfill these criteria the image is first enhanced using generic image quality improvement methods such as homomorphic filtering, median-based noise removal and contrast stretching (Figure $3.1 \mathrm{~B}$ ). Such enhanced images are then treated with a localized intensity thresholding algorithm extracting pixels which have lower-than-average intensity with the average intensity calculated over a window of a specified size (Figure 3.1 C). The algorithm is repeated for multiple window sizes and the final result is an intersection of the results obtained in all iterations. Thus, the pixels which show below-average intensity regardless of averaging window size are classified as potential foreground pixels. On the other hand, the enhanced cell image is also processed using a Sobel edge detector in order to find cell boundaries (Figure 3.1D). The detected edges are processed using a fill / connect algorithm which connects neighboring edges resulting in a uniform binary bitmap containing pixels corresponding to objects with distinct edges (Figure 3.1E). An intersection of this binary bitmap with the one obtained with intensity thresholding is assumed to be a correct foreground mask (Figure 3.1F).

The second stage consists of manual tube identification where the software user depicts beginning and ending points of individual tubes on the processed image. As result of this process a tube topology graph is formed which, in combination with the information obtained in the segmentation stage, enables to gather valuable statistics such as total and average tube length, average tube width, number of tube branching points and total tube area (Figure $3.1 \mathrm{G}$ ). 

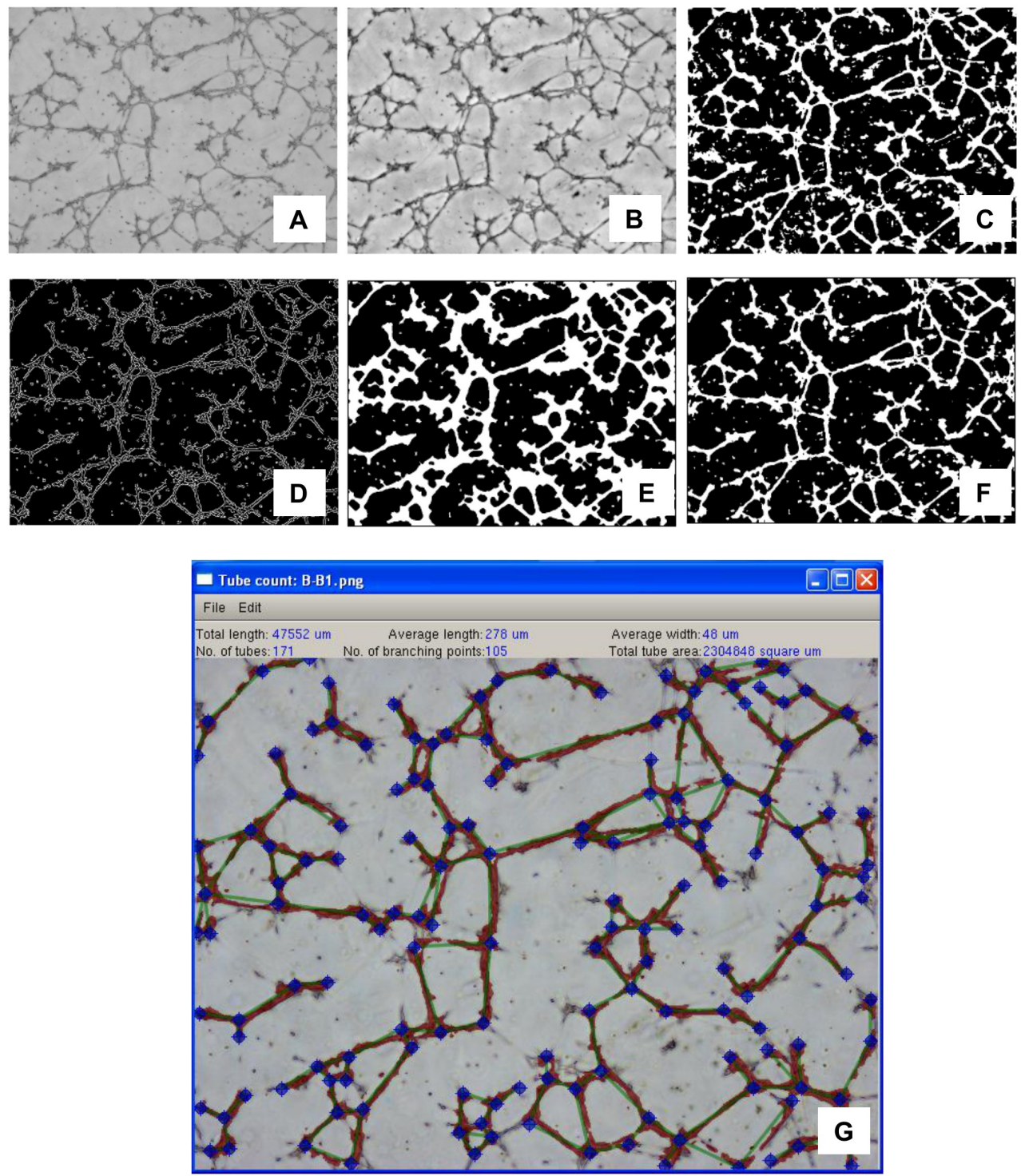

Figure 3.1: Image segmentation steps. Original image (A), quality enhancement (B), intensity thresholding (C), edge detection (D), edge connection / filling (E), final segmentation result (F). Screenshot of the tube topology analysis $(G)$. 


\subsubsection{EL-MSC characterization}

\section{RNA isolation and quantitative PCR}

Total RNA was isolated using TRIZOL reagent according to the manufacturer's protocol. Briefly, $1 \mathrm{ml}$ of Trizol reagent was added per T25 flask (cells cultured in basic medium) or per well (cells cultured on Matrigel in 6-well plates). Samples were incubated for $5 \mathrm{~min}$ at room temperature to allow complete dissociation. Phase separation was performed by adding chloroform, and then samples were shaken vigorously for 15 seconds and incubated for 3 min at room temperature. After that samples were centrifuged at $12,000 \mathrm{x}$ g for $15 \mathrm{~min}$. RNA was precipitated by mixing the aqueous phase with isopropyl alcohol followed by 10 min incubation at room temperature. Samples were centrifuged again and the remaining RNA pellet was washed with $75 \%$ ethanol. The obtained samples were dissolved in water. The quantity and quality of RNA was analyzed using spectrophotometry (ND-1000 spectrophotometer).

For first strand cDNA synthesis, $500 \mathrm{ng}$ of RNA was used in combination with Superscript II (Invitrogen) according to the manufacturer's protocol. One $\mu \mathrm{l}$ of $3 \mathrm{x}$ diluted cDNA was used for further gene amplification. PCR was performed in a Light Cycler real time PCR machine (BioRad). Data was analyzed using Bio-Rad iQ5 software. Expression of endothelial genes was calculated relative to GAPDH levels by the comparative $\triangle \mathrm{CT}$ method. Primers used in the study are listed in Table 3.1.

\begin{tabular}{|l|l|}
\hline $\begin{array}{l}\text { CD31 (Platelet Endothelial } \\
\text { Cell Adhesion Molecule-1) }\end{array}$ & $\begin{array}{l}\text { F 5' TCTATGACCTCGCCCTCCACAAA 3' } \\
\text { R 5' GAACGGTGTCTTCAGGTTGGTATTTCA 3' }\end{array}$ \\
\hline KDR (VEGF receptor 2) & F 5' ACTTTGGAAGACAGAACCAAATTATCTC 3' \\
& R 5' TGGGCACCATTCCACCA 3' \\
\hline vWF (von Willebrand factor) & $\begin{array}{l}\text { F 5' TGCTGACACCAGAAAAGTGC 3' } \\
\text { R 5' AGTCCCCAATGGACTCACAG 3' }\end{array}$ \\
\hline GAPDH & F 5' CGCTCTCTGCTCCTCCTGTT 3' \\
& R 5' CCATGGTGTCTGAGCGATGT 3' \\
\hline
\end{tabular}

Table 3.1: Primers used for qPCR.

\section{Immunostaining}

Cells for immunostaining were fixed with $70 \%$ ethanol and permeabilized with $0.01 \%$ Triton-X. To block non-specific background staining, cells were incubated with $5 \%$ BSA (Sigma- Aldrich) in PBS for 30 min. Cells were then incubated with mouse antihuman CD31 antibody (Dako) or with rabbit anti-human VEGFR2 (Cell Sygnaling) for 2 hours. Cells were washed in PBS with $1 \%$ BSA and subsequently incubated with the secondary antibody (AlexaFluor 488 conjugated goat anti mouse or AlexaFluor 594 conjugated goat anti rabbit, Invitrogen) for 1 hour. Cells were washed and counterstained with DAPI and photographed with a BD Pathway ${ }^{\mathrm{TM}}$ Bioimager. 


\section{Acetylated low-density lipoprotein (ac-LDL) uptake assay}

iMSCs were cultured in EGM-2 on an XYZ shaker for 10 days, then transferred to Matrigel and cultured for another 24 hours. Cells were then recovered from Matrigel by 30 min incubation in a 1:1 mixture of $0.25 \%$ trypsin and dispase (BD Bioscience). Recovered cells were seeded in 96-well plates and cultured in EGM-2 for one more day. Subsequently, cells were incubated for 4 hours in EGM-2 supplemented with 10 $\mu \mathrm{g} / \mathrm{ml}$ Dil-labeled ac-LDL (Invitrogen) at $37^{\circ} \mathrm{C}$ in a humid atmosphere. Finally, cells were washed with PBS 3 times.

\subsubsection{Biodegradable scaffold preparation}

Porous scaffolds composed of a 50/50 blend of poly-(l-lactic acid) (PLLA) and polylacticglycolic acid (PLGA) were fabricated by a salt-leaching process. PLLA (Polysciences) and PLGA (Sigma-Aldrich) were dissolved 1:1 in chloroform (Fisher Scientific) with a final concentration of $5 \%$ (wt/vol). Two $\mathrm{ml}$ of this solution were poured into Teflon containers (Savillex) with a diameter of $50 \mathrm{~mm}$ and homogenized with $3.4 \mathrm{~g}$ of sodium chloride particles with an average grain size of $425 \mu \mathrm{m}$. The solvent was evaporated overnight under nitrogen flow. To leach the salt, the obtained polymer films were immersed in distilled water for 6 hours (changed every hour). The leached films with a thickness of $500 \mu \mathrm{m}$ and a pore size of $200 \pm 60 \mu \mathrm{m}$ were lyophilized overnight and subsequently cut in circular disks with a diameter of $5 \mathrm{~mm}$. Before culture the scaffolds were sterilized in $70 \%$ ethanol for 2 days, washed three times with PBS and incubated in culture medium overnight.

\subsubsection{PLLA / PLGL construct preparation and implantation}

Constructs for implantation were prepared as described before [58]. Briefly, 500,000 cells were pooled and resuspended in $20 \mu \mathrm{l}$ of a 1:1 mixture of EGM-2 medium without growth factors and growth factor reduced Matrigel. This suspension was applied onto the scaffold and allowed to be absorbed and solidify for $30 \mathrm{~min}$ at $37^{\circ} \mathrm{C}$ in a humid atmosphere with $5 \% \mathrm{CO}_{2}$. Culture medium (EGM-2) was then added; scaffolds were detached from the wells and cultured further on a shaker at $37^{\circ} \mathrm{C}$ in a humid atmosphere with $5 \% \mathrm{CO}_{2}$. Medium was changed every other day. After 10 days of culture samples were fixed in $10 \%$ formalin or implanted into mice.

Male 6-week old NMRI-nu mice (Harlan) were anesthetized with a mixture of isofluorane and oxygen after which constructs were subcutaneously implanted in four pockets. Animals were housed at the Central Laboratory Animal facility (Utrecht University, Utrecht, The Netherlands), and experiments were approved by the local animal care and use committee. Two weeks after implantation mice were sacrificed and implants were recovered. Samples were fixed in $10 \%$ formalin, embedded in paraffin and sectioned at $5 \mu \mathrm{m}$ before staining. 


\subsubsection{Histochemical staining and image analysis}

Hematoxylin (Sigma-Aldrich) and eosin (Sigma-Aldrich) staining as well as Masson's trichrome (Merck Chemicals) staining were performed according to manufacturers' protocols. Samples were photographed using a Nikon Elipse E600 microscope. Based on Masson's trichrome stainings vessels were counted manually by 4 observers blinded to the sample composition. Three areas of each sample (10 samples per condition) were used for this quantification.

For detecting endothelium of human origin CD31 staining was performed. Antigen retrieval was achieved with IHC-Tek Epitope Retrieval Solution (IHC World). Sections were then incubated with mouse-anti-human CD31 primary antibody (Dako), which does not cross-react with mouse tissue. Following this, biotinylated horse anti-mouse secondary antibody (Antibodies-online.com) was applied. Slides were developed with Labeled Streptavidin Biotin (LSAB) with DAB Chromogen (IHC World) and weakly counterstained with Mayer's hematoxylin (Sigma-Aldrich).

\subsubsection{Statistics}

Each experiment was performed in triplicate. The data was analyzed using Student's t-test at $\mathrm{p}<0.05$. Data that required multiple comparison test was analyzed in SPSS (PASW statistics) using one-way Anova followed by Tukey's multiple comparison test $(\mathrm{P}<0.05)$. Error bars on graphs represent standard deviation or $95 \%$ confidence interval as indicated in the graph legends.

\subsubsection{Ethics statement}

Human mesenchymal stromal cells (hMSCs) were isolated from human bone marrow from donors with written informed consent. This study was carried out in strict accordance with the recommendations of Medisch Ethische Toetsings Commissie Twente (Medical Ethical Research Committee Twente) and was approved by this Committee.

The animal study reported on in this manuscript was ethically assessed a priori by an animal ethics committee 2010-III-10-125 DEC-Utrecht. Animals were housed at the Central Laboratory Animal facility (Utrecht University, Utrecht, The Netherlands), and experiments were approved by the local animal care and use committee Dierexperimentencommissie Academisch Biomedisch Centrum (DEC-ABC). All surgery was performed under isofluorane/oxygen anesthesia, and all efforts were made to minimize suffering.

\section{$3.3 \quad$ Results}

\subsubsection{Endothelial differentiation medium effects cell shape}

Because EGM-2 induces endothelial differentiation in human amniotic fluid-derived stem (AFS) cells [46], we decided to use this medium to differentiate MSCs towards 
an endothelial-like phenotype. First, we analyzed whether MSCs cultured in EGM-2 acquired an endothelial-like phenotype. HUVECs were used as positive control for expression of endothelial markers. Cytoskeleton staining and qPCR study showed that the observed change of shape and size of pre-differentiated MSCs was not followed by expression of endothelial specific markers such as CD31, KDR or vWF (data not shown). Additionally, MSCs grown in abovementioned conditions did not take up ac-LDL (data not shown). We did observe a difference in cell shape between MSCs cultured in EGM-2 and basic medium. Cells cultured in EGM-2 were clearly more elongated than MSCs cultured in basic medium but exact measurements of cell shape and area were difficult due to the high cell density. To quantify this phenomenon, sub-confluent cell culture was necessary. Cells were trypsinised and seeded at lower density and further growth was allowed for 2 more days to ensure cell spreading. Morphology of naïve MSCs showed a typical fibroblast-like shape in contrast to cells grown in EGM-2 (Figure 3.2A,B). The average size of MSCs cultured in basic medium was approximately $100 \mu \mathrm{m}^{2}$ and the average cell circularity was 3 (circularity of 1 represents round objects, the higher the coefficient is, the less round object it describes). The shape of pre-differentiated MSCs was significantly altered: the area increased to approximately $200 \mu \mathrm{m}^{2}$ and the circularity coefficient was close to 5 , suggesting that cells grown in EGM2 were more elongated than naïve MSCs (Figure 3.2 C-D). The observed phenomenon was opposite to what was expected because MSCs from other sources $[59$ acquired a cobblestone-like morphology typical for endothelial cells.

\subsubsection{Wound healing assay}

The wound-healing assay is a simple method to study directional cell migration in vitro [60]. Migration of vascular endothelial cells plays an important role in vasculogenesis and angiogenesis 61. We used the scratch wound healing assay of tissueculture cell monolayers to assess the migration potential of predifferentiated MSCs. The wound recovery increased over time and the rate of this was taken as a measure of cell migration (Figure 3.3A). We observed that 10 days culture in EGM-2 significantly increased the migration rate of MSCs (Figure $3.3 \mathrm{~B}$ ). The size of the wound in EGM-2-cultured MSC monolayer was reduced by $40 \%$ after 8 hours and the wound closed completely after 24 hours. Naïve MSCs needed 24 hours for a $45 \%$ reduction in wound size and 48 hour to close the wound completely. This assay showed that MSCs cultured in EGM-2 migrate faster than naïve MSCs.

\subsubsection{Capillary-like structure formation}

The angiogenic capability of various cell types was assessed using an in vitro capillary formation assay on Matrigel. Three cell types were used for this study: HUVEC which served as positive control, bone-marrow derived hMSCs and iMSCs. We decided to test whether iMSCs react in a similar way to hMSCs to serve as a cell source for future studies without problems associated with donor variation. As shown in Figure 3.4A, cells from each cell type performed with similar efficiency. Measurement of total tube length (Figure $3.4 \mathrm{~B}$ ) revealed significant but not critical differences between iMSCs 
A
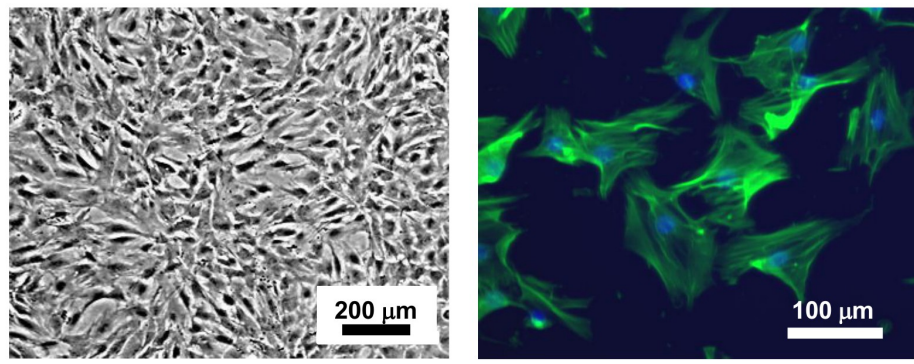

B
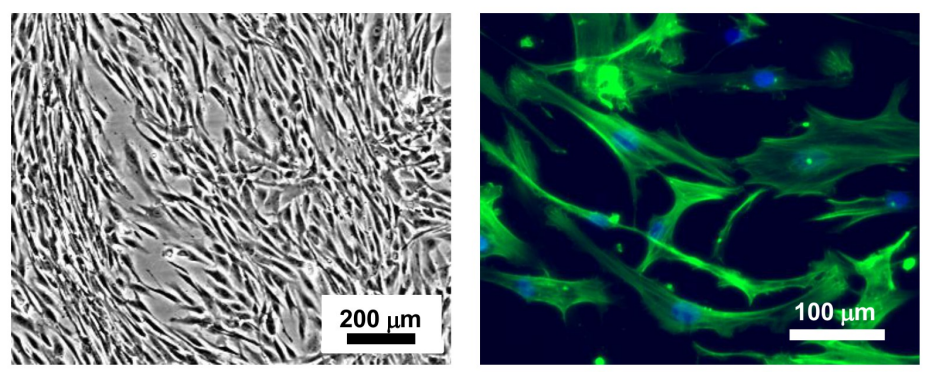

C

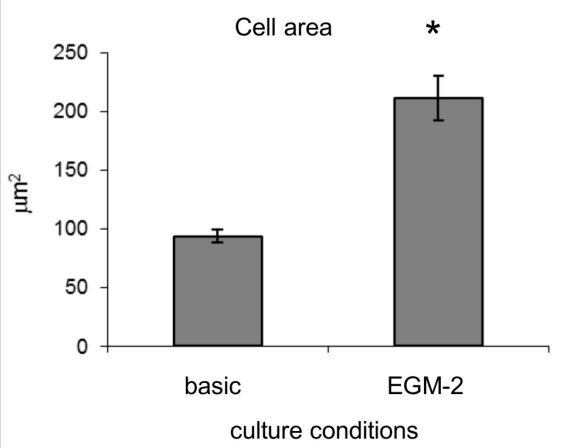

D

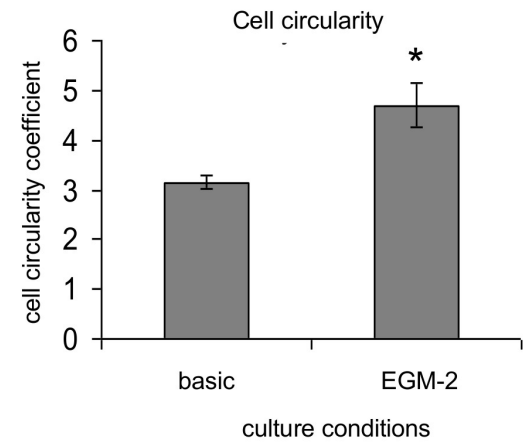

Figure 3.2: Predifferentiation of iMSCs. Cell shape after 10 days of culture in basic medium (A) and in EGM-2 (B). Average cell area (C) was compared. Cell shape was characterized based on circularity coefficient (D). Error bars represents $95 \%$ confidence interval, * denotes statistical significance $(\mathrm{P}<0.05)$.

and hMSCs and HUVECs. Total tube area was similar in all three cases and the number of branching points did not reveal significant differences between iMSCs, hMSCs and HUVECs. Comparison of all those parameters allowed us to use iMSCs as a model of MSCs for further study. 
A Oh $12 \mathrm{~h}$ $24 \mathrm{~h}$
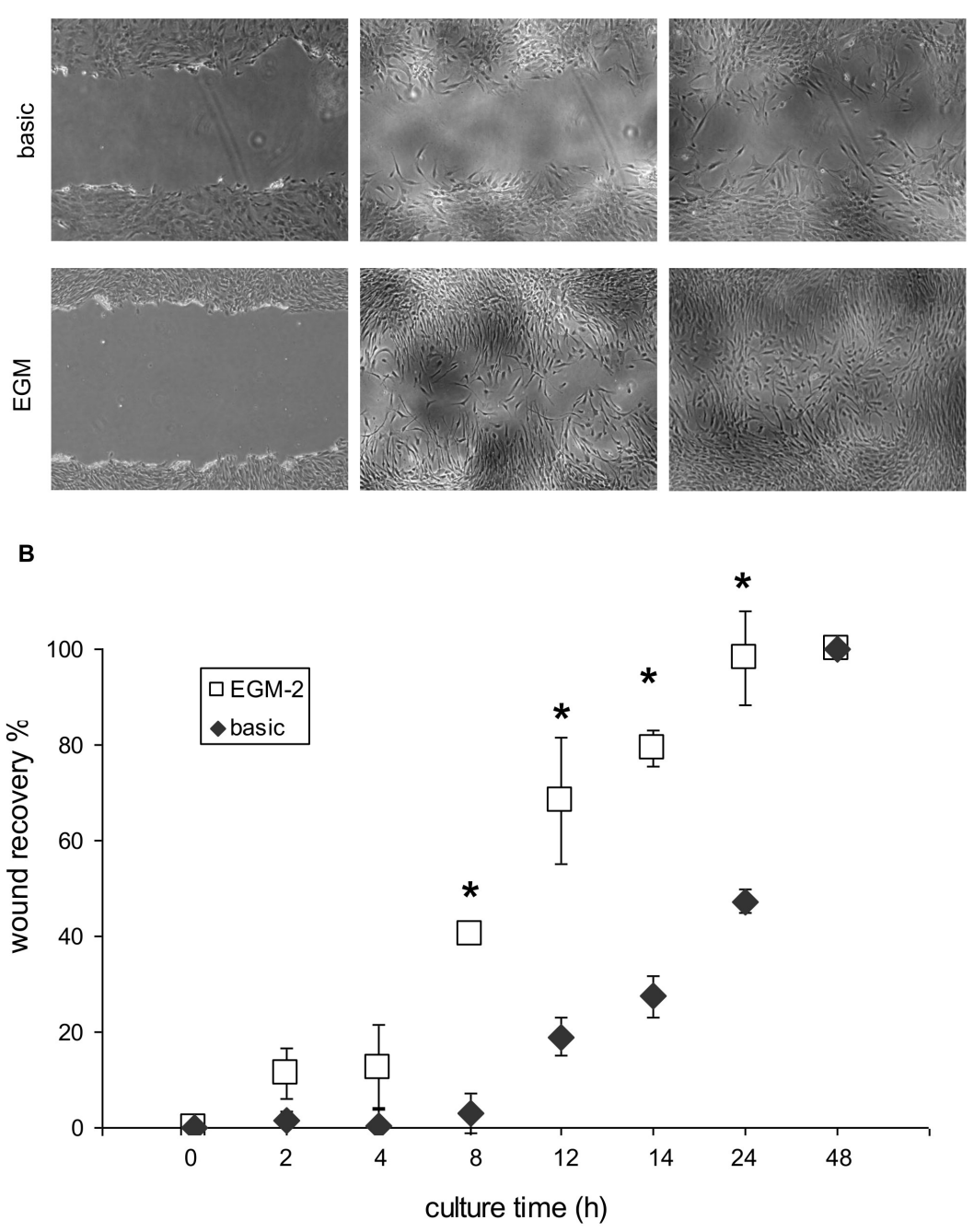

Figure 3.3: Wound healing assay. Pictures were taken directly after making the wound, 12 and 24 hours later (A). Quantification of wound recovery was performed with TScratch software and presented on the graph (B). Error bars represent standard deviation, ${ }^{*}$ denotes statistical significance $(\mathrm{P}<0.05)$.

As we described above, MSCs expanded in endothelial medium undergo significant changes in shape. We hypothesized that these changes might influence the results of the Matrigel assay. In order to confirm this, we performed a Matrigel assay with naïve MSCs and MSCs expanded in EGM-2 (pre-differentiated MSCs). Both naïve MSCs 
A

iMSC
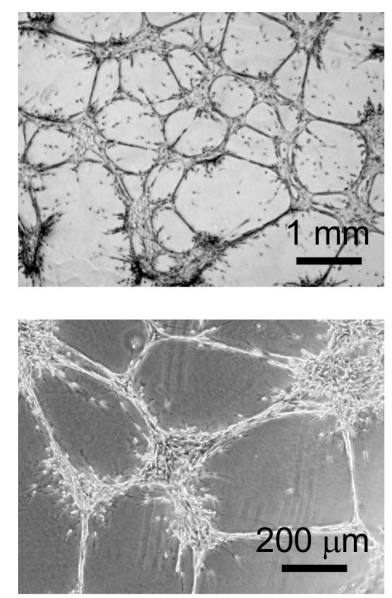

hMSC
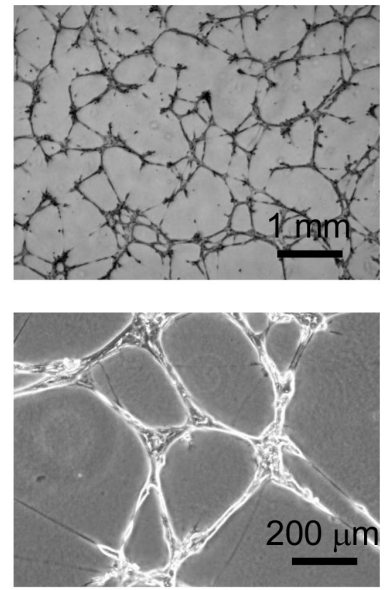

HUVEC
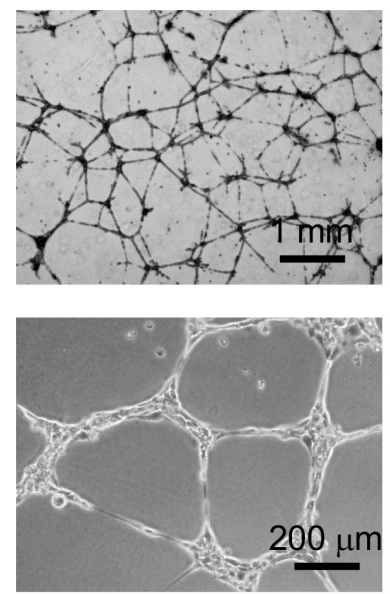
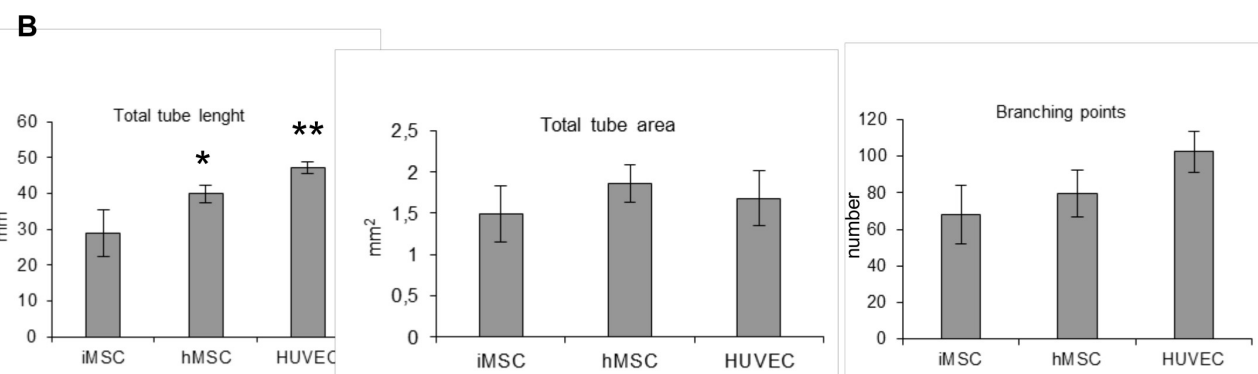

Figure 3.4: Capillary-like structures formation on Matrigel. ELhMSCs, EL-iMSCs and HUVECs were cultured on Matrigel for 24h in EGM-2 medium (A). Total tube length, total tube area and number of branching points were compared $(\mathrm{B}) .{ }^{*}$ and ${ }^{* *}$ denote statistical significance $(\mathrm{P}<0.05)$.

as well as pre-differentiated MSCs were seeded onto Matrigel in basic medium or in EGM-2. We observed cell behavior on Matrigel in a time course study (Figure 3.5) where we found that naïve MSCs seeded in basic medium start to form capillaries on Matrigel at an earlier time point than pre-differentiated MSCs but those capillaries were very unstable and disrupted after 24 hours. A similar situation was observed when naïve MSCs were seeded on Matrigel in EGM-2. In contrast, pre-differentiated MSCs started to form capillaries with a 20 hours delay compared to naïve MSCs. However, those capillaries grew thicker and created a more complex network during the next 7 days. This showed that the expansion phase in EGM-2 is crucial for the stability of capillary structures. 

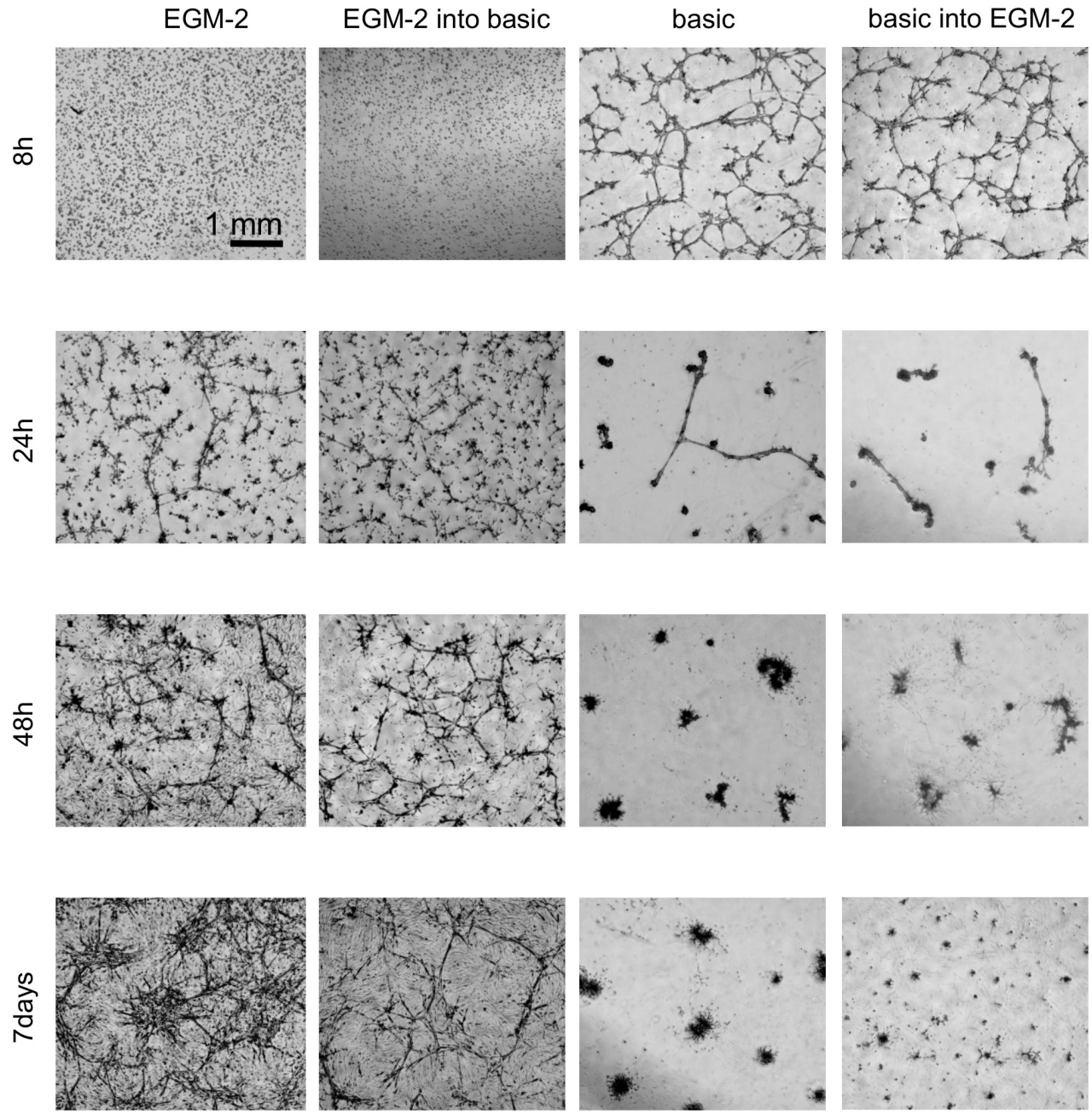

Figure 3.5: Capillary-like structures formation on Matrigel. Time course study. iMSCs were cultured for 10 days in basic or EGM-2 medium and then seeded on Matrigel in basic or EGM-2 medium. Dynamics of capillaries formation was observed for following 7 days.

Quantification of the capillaries obtained in different conditions (Figure 3.6) demonstrated a significant increase in the total tube length, total tube area, number of tubes and branching points when cells were expanded in EGM-2 even when the process of tube formation was performed in basic medium. This means that cells expanded in EGM-2 behave more like endothelial cells even when used in less promoting conditions (basic medium is not supplemented with growth factors as much as EGM-2). 
This is interesting when taking into account that endothelial cells need well supplemented medium to survive prolonged culture: HUVECs seeded in basic medium did not survive (data not shown).

\subsubsection{Endothelial induction of MSCs}

Since we did not observe endothelial marker expression in MSCs when growth factors and shear stress were applied we decided to test whether introduction of extracellular matrix could trigger an endothelial phenotype in MSCs. Cells cultured for 10 days in EGM-2 on a XYZ shaker were reseeded on Matrigel for another 24 hours. This short period of Matrigel culture allows for endothelial induction without the risk of MSCs modifying the gel itself 62]. Cells obtained in this way will be called endothelial-like MSCs (EL-MSCs).

\subsubsection{EL-MSCs express endothelial markers}

To characterize the phenotype of EL-MSCs, the expression of several endothelial genes, CD31, KDR and vWF, was assessed. hMSCs from 2 donors and iMSCs were used in this study. In all three cases the expression of CD31 and KDR was significantly higher in EL-MSCs than in naïve MSCs from the same source. CD31 expression was up-regulated between 15-60 times and KDR expression between 80-1000 times (Figure 3.7 A). In the case of vWF the expression was 5-6 times higher in hMSCs from both donors but not in case of the immortalized clone (Figure $3.7 \mathrm{~A}$ ). To confirm the qPCR data, immunostaining was performed. iMSCs expanded in EGM-2, seeded on Matrigel for $24 \mathrm{~h}$ and recovered with dispase/trypsin solution were stained for CD31 and KDR. Staining directly on Matrigel was not possible due to the very high background signal generated by unspecific antibody binding to Matrigel. HUVECs and naïve iMSCs served as positive and negative control respectively. We observed cells positive for tested markers among EL-iMSCs whereas naïve iMSCs were negative (Figure 3.7B). The specificity of the antibody for both markers was confirmed by HUVECs staining - cells recovered from Matrigel maintained round shape and did not spread on tissue culture plastic, which made the observation of characteristic staining on the border of neighboring cells very difficult.

The last characteristic of endothelial cells we tested was the ability of EL-MSCs to take up ac-LDL. iMSCs that were expanded in EGM-2 for 10 days and seeded on Matrigel for 24 hours were then recovered from the gel and reseeded on tissue culture plastic. Twenty-four hour later cells were incubated with ac-LDL for 4 hour, washed and imaged. Most of the cells were lost during this process. The cells that survived returned to a fibroblast-like morphology but were still able to take up ac-LDL. This uptake was however limited in the view of the number of positive cells when compared to HUVECs but was not observed at all in naïve MSCs (Figure 3.7B). 

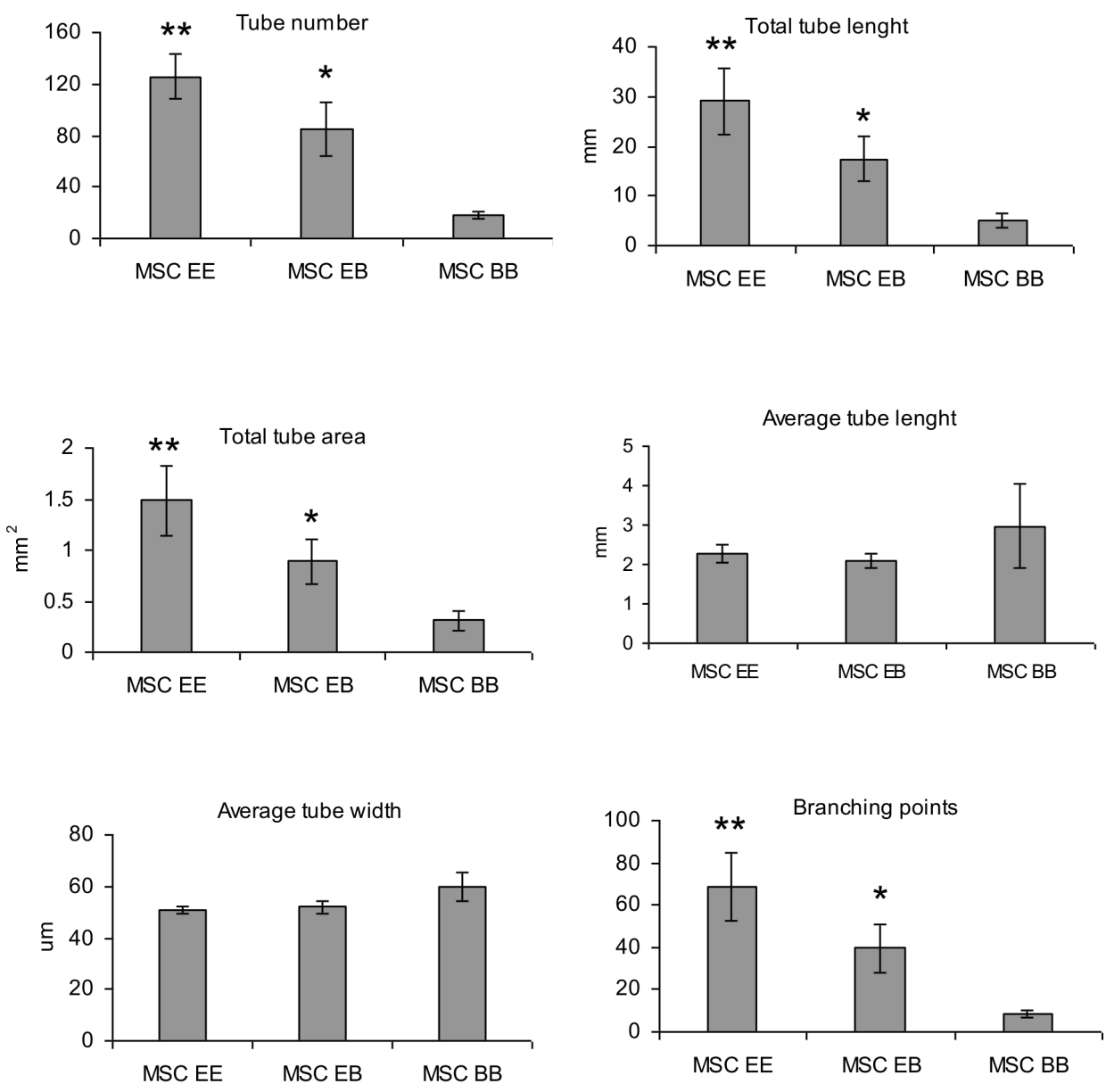

\section{Culture conditions}

Figure 3.6: Quantification of capillary-like structures on Matrigel. Quantification of tube formation by cells cultured in 3 different conditions: cells predifferentiated in EGM-2 and seeded on Matrigel in the same medium (EE), cells predifferentiated in EGM-2 and seeded on Matrigel in basic medium (EB) and naïve MSCs expanded in basic medium and seeded on Matrigel in basic medium (BB). Graphs show total tube length, average tube length and average tube width, total tube area, number of tubes and number of branching points per picture. Error bars represent standard deviation, ${ }^{*}$ and ${ }^{* *}$ denotes statistical significance $(\mathrm{P}<0.05)$ towards all other bars. 
A

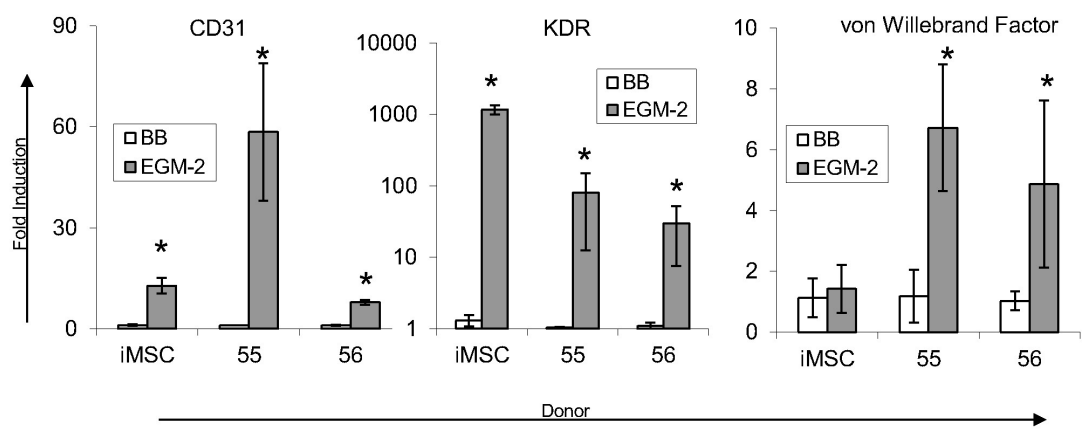

B
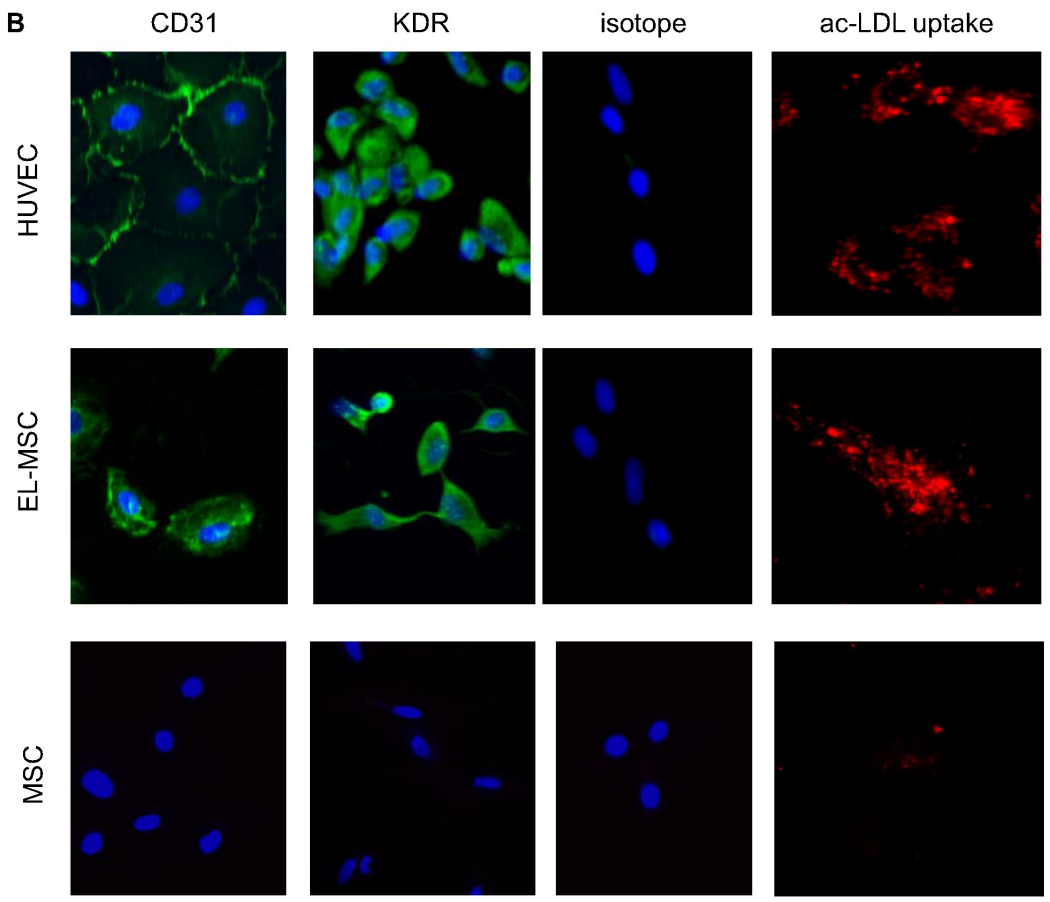

Figure 3.7: Endothelial marker expression in differentiated MSCs. Gene expression profiles of endothelial markers in EGM-2 and Matrigel culture (EE) (A). Expression is indicated as fold induction compared to cells grown in basic medium (BB) on plastic and normalized to GAPDH RNA. hMSCs from donors 55 and 56 and iMSCs were used in this experiment. Error bars represent standard deviation, * denotes statistical significance $(\mathrm{P}<0.05)$. Staining for endothelial markers (B).

\subsubsection{PLLA / PLGL construct}

We previously reported the induction of vessel networks in engineered tissue constructs using a three-dimensional coculture system consisting of cells seeded on porous and 
biodegradable polymer scaffolds [58]. The scaffolds were composed of 50\% PLLA and $50 \%$ PLGL, with a pore size of $200 \pm 60 \mu \mathrm{m}$ (Figure $3.8 \mathrm{~A}$ and $3.8 \mathrm{~B}$ ). We have previously vascularized muscle tissue with tissue engineered constructs combining PLLA/PLGL scaffolds, Matrigel and HUVECs [58]. To assess the angiogenic potential of EL-MSCs we have compared their ability to improve construct vascularization with that of HUVECs and naïve MSCs. C2C12 monoculture was used as negative control for angiogenic potential of constructs seeded with C2C12 with HUVECs, MSCs or EL-MSCs in 1:1 ratio.

We showed that scaffolds filled with Matrigel without cells and cultured for 10 days in EGM-2 kept their structure (Figure 3.8C). Hematoxylin/eosin staining performed on cross sections of constructs 10 days after cell seeding indicates that cells attached to and grew on the scaffolds in all four culture systems (Figure 3.8D-G), no differences in cell density were detected. Elongated cells were observed in all used schemes, indicating cell-matrix interactions.

To observe the therapeutic potential of EL-MSCs we subcutaneously implanted tissue engineered constructs in immune-deficient mice (NMRI-nu, Harlan). The constructs were permeated with host blood vessels (Figure 3.9 and the number of ingrown vessels were quantified. There were no significant differences between constructs seeded with $\mathrm{C} 2 \mathrm{C} 12$ cells alone or in coculture with HUVECs or with naïve MSCs (Figure 3.10A). Only in constructs seeded with C2C12 cells in coculture with EL-MSCs the number of vessels was significantly higher compared to all other tested conditions. These in vivo results showed that introduction of EL-MSCs in the implant improve construct vascularization and by that can promote cell survival in large grafts.

Staining of implants with anti-human specific endothelial antibody (anti-CD31) demonstrated that in the constructs seeded with EL-MSCs vessels lined with human cells were present (Figure $3.10 \mathrm{~B}$ ). Moreover, these vessels contained intraluminal red blood cells suggesting that the vessels had anastomosed with the host vasculature.

\subsection{Discussion}

Proper vascularization is essential for maintaining tissue well-being and functionality. It is also crucial for engineering of bone graft constructs, liver and many other tissues used for transplantation $63 \sqrt{65}$. To provide extensive tissue or graft vascularization, a source of endothelial cells must be found. Those cells have to be available in large quantities and be able to create a vascular network within the tissue. Furthermore, this network should be both structurally and functionally appropriate.

Since BM-MSCs are widely used for bone tissue engineering, we decided to investigate whether we can use the same cell source for vascular network formation. In this study we used a number of techniques including immune-fluorescent imaging, qPCR and quantitative image analysis to examine endothelial differentiation of MSCs at the cellular and protein level. This study is the first to fully describe differentiation of MSCs into endothelial-like cells that perform in an in vivo study better than undifferentiated (naïve) MSCs. 
A

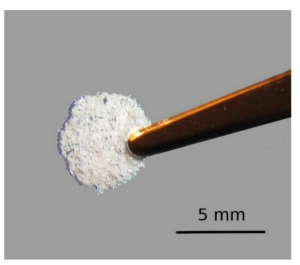

B

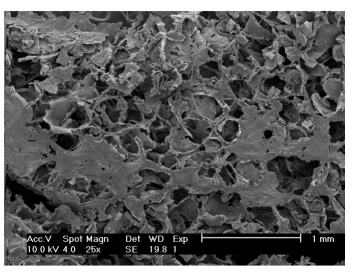

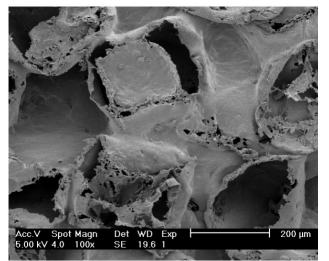

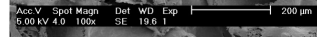

C
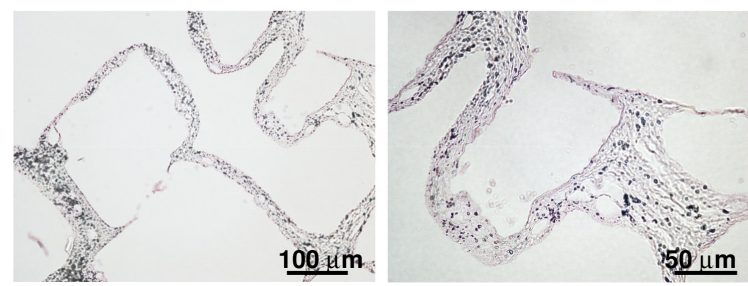

D

E
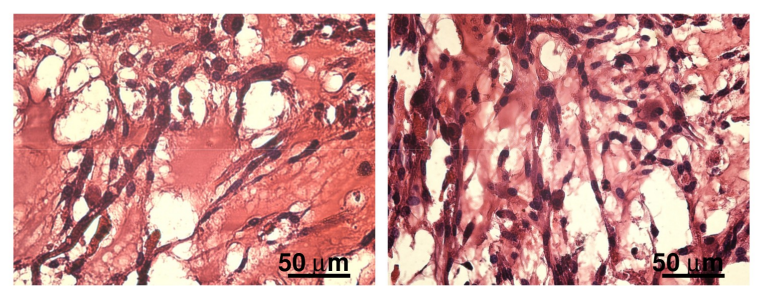

$\mathbf{F}$

G
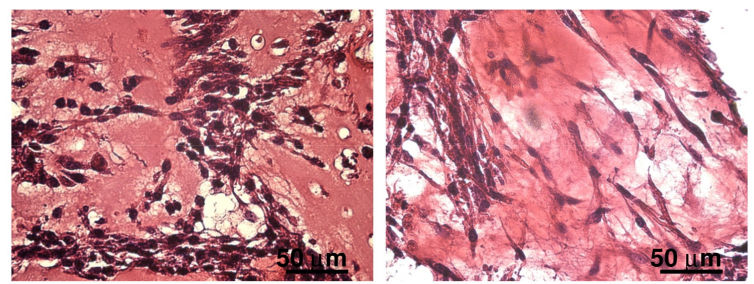

Figure 3.8: In vitro vascularization of polymeric construct combined with Matrigel and cells. PLLA/PLGL scaffold before cell seeding (A). Scanning electron microscope (SEM) pictures of scaffold taken after gold coating (B). Eosin / hematoxylin staining of tissue sections taken from constructs after 10 days of in vitro culture without cells (C), with $\mathrm{C} 2 \mathrm{C} 12$ (D), with $\mathrm{C} 2 \mathrm{C} 12$ and MSCs (E), with C2C12 and HUVECs (F), with C2C12 and EL-MSCs (G).

BM-MSCs can be obtained in large quantities and further expanded in vitro. For most in vivo applications, a minimal number of cells, in the range of $10^{8}-10^{9}$, is necessary [66 and this can be easily obtained from MSCs after only a few passages. We did not observe any serious loss of endothelial potential in cells expanded up to such 

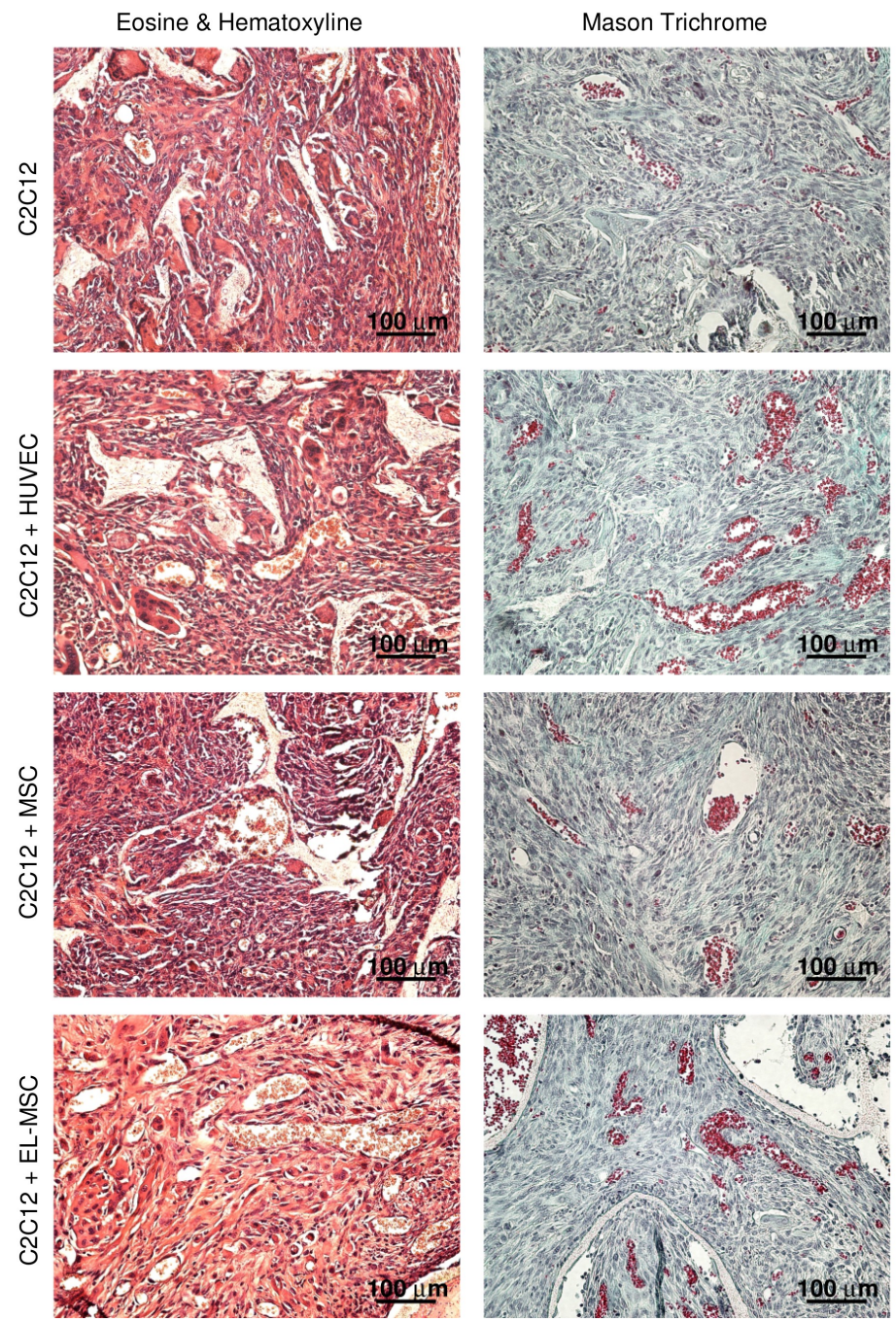

Figure 3.9: In vitro vascularization of polymeric construct combined with Matrigel and cells. PLLA/PLGL scaffold before cell seeding (A). Scanning electron microscope (SEM) pictures of scaffold taken after gold coating (B). Eosin / hematoxylin staining of tissue sections taken from constructs after 10 days of in vitro culture without cells (C), with $\mathrm{C} 2 \mathrm{C} 12$ (D), with $\mathrm{C} 2 \mathrm{C} 12$ and MSCs (E), with C2C12 and HUVECs (F), with C2C12 and EL-MSCs (G).

a level. In the differentiation protocol MSCs were first cultured for 10 days in EGM-2 medium on an orbital shaker. The effect of this step was limited to changes in morphology and ability to perform in the Matrigel assay. After this culture period we did not observe a change either in marker expression or in the ability to take up ac-LDL. 
A

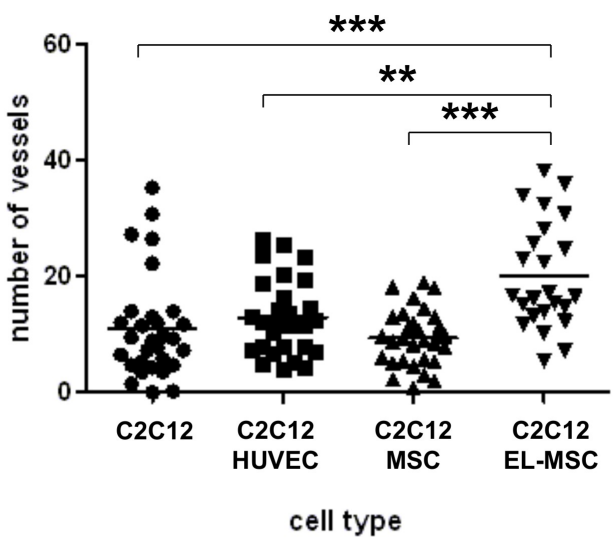

B

$\mathrm{C} 2 \mathrm{C} 12$

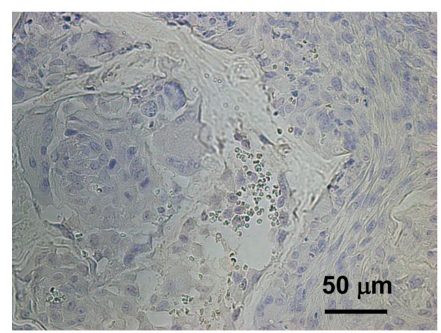

$\mathrm{C} 2 \mathrm{C} 12+\mathrm{MSC}$

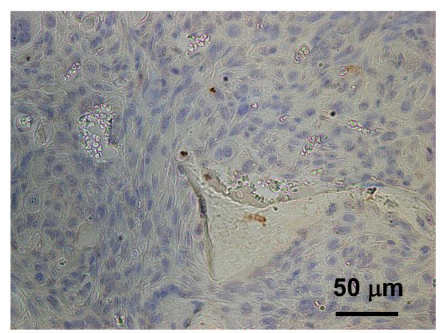

$\mathrm{C} 2 \mathrm{C} 12+\mathrm{HUVEC}$

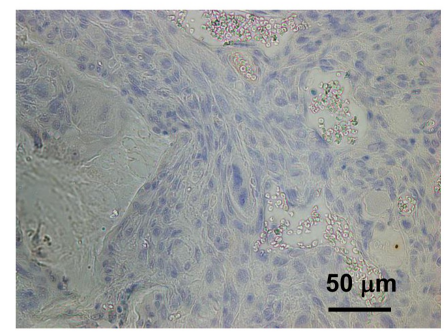

$\mathrm{C} 2 \mathrm{C} 12+\mathrm{EL}-\mathrm{MSC}$

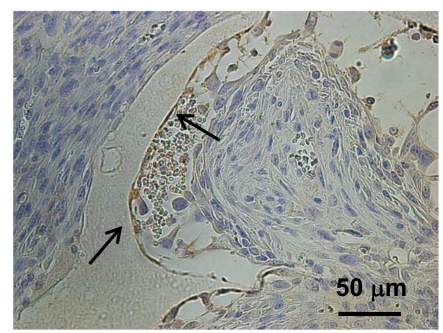

Figure 3.10: Quantitative analysis of vessels in polymeric constructs. Number of vessels per sample was quantified by four people blinded for the conditions $(\mathrm{A}) .{ }^{* *}$ denotes statistical significance $(\mathrm{P}<0.01),{ }^{* * *}$ denotes statistical significance $(\mathrm{P}<0.001)$. Tissue construct sections were stained with anti-human CD31 antibody (brown, indicated by black arrows) and counterstained with hematoxylin (blue) (B).

Nevertheless, this step was crucial for further performance in functional assays and differentiation. Functional properties of EGM-2-cultured MSCs were demonstrated using the Matrigel assay. MSCs that underwent 10 days of culture in EGM-2 medium performed with similar efficiency to endothelial cells (HUVECs) in Matrigel sprouting 
assay and much better than naïve MSCs. Interestingly, capillaries formed by MSCs were more stable than the ones formed by HUVECs - when applying prolongated culture, capillaries formed by HUVECs get disorganized whereas capillaries formed by MSCs remain stable. This can indicate that while forming capillaries MSCs can play both the role of endothelial cells that create vessels as well as the role of pericytes that stabilize those vessels 67 . The fact that MSCs can take the role of pericytes in various engineered constructs has already been shown by Chamberlain et al [68]. They reported that in co-culture with HUVECs on collagen modules MSCs became smooth muscle actin positive and migrated to surround the EC layer of the vessel (location typical for pericytes).

Pre-differentiated MSCs were also able to acquire endothelial characteristic (endothelial markers expression and ability to take up ac-LDL) after 24h culture on Matrigel which was not the case when using naïve MSCs. This showed that growth supplements combined with shear force play an important role in triggering endothelial differentiation of MSCs, though this effect cannot be concluded based on marker expression only. Although the molecular mechanisms of angiogenesis and vasculogenesis are currently not fully understood, there is evidence strongly supporting the crucial role of VEGF in both processes 69. The expression of the main receptor for VEGF, KDR, did not increase in hMSCs after culture in EGM-2, but other studies showed that many key events in VEGF signaling occur inside endothelial cells and are regulated by endosomal receptor trafficking [70]. According to this model even basally expressed KDR can propagate the VEGF signaling. The VEGF-KDR complex is endocytosed directly after signal transduction and then proteolytic cleavage takes place, releasing the cytoplasmic KDR dimmer and making it available to form new signaling complexes. In our work we did not check for expression of Neuropilins and Ephiryns that play a crucial role in both VEGF and KDR endocytosis 71, 72 but we hypothesize that this can be the mechanism that triggers MSC differentiation towards endothelial lineages. This would be similar to the processes that occur in the embryo when the multipotent mesodermal progenitor cells differentiate in situ into endothelial cells during early stages of vascular development. VEGF, together with bFGF, is known to play a critical role in these events 73. The input of Matrigel on pre-differentiated MSCs that leads to further differentiation towards endothelial cell phenotype can be explained based on the work of Lozito et al. 62. They showed that change in the composition and crosslinking level of the matrix influences MSC differentiation towards endothelial and smooth muscle phenotype. Osawa et al. 74 showed that CD31 can be the mechanoresponsive molecule in case of endothelial cells, but we did not observe an increase in CD31 expression in MSCs before Matrigel stimulation. Therefore, two possible explanations of the effect of Matrigel on MSCs can be suggested. There can be another molecule on MSCs that acts as mechanoreceptor or there is a positive feedback loop between the ECM stimulation and CD31 expression in MSCs. Culture on Matrigel also induced KDR expression in MSCs which can further stimulate endothelial differentiation by increasing MSC sensitivity to VEGF present in culture medium. These results are similar to the ones obtained by $\mathrm{Gu}$ et al. 75] while studying murine embryonic stem cells. They showed that increased ex- 
pression of endothelial markers is induced by extracellular matrix via CEACAM1, a glycoprotein involved in cell-cell adhesion. Therefore we can hypothesize that the role of Matrigel in our differentiation system is mainly to provide the environment in which MSCs can create cell-cell contact promoting endothelial differentiation. Nevertheless, those results suggest that careful examination of the MSC differentiation protocols is necessary as our knowledge concerning their signaling pathways is still limited.

CD31 staining performed on the constructs with EL-MSCs revealed the presence of human cells lining the walls of vessels. These vessels were fully functional as demonstrated by the presence of erythrocytes in the vessel lumens. This is a proof that EL-MSCs actively participated in building of these vessels. Nevertheless, there were also vessels present that were not human CD31 positive. This can suggest that the EL-MSC influence on vascularization is also due to their trophic effect on surrounding tissues. There is also the possibility that EL-MSCs create a network within the sample that is then gradually replaced by in-growing vessels. In that case the input of EL-MSCs can be limited to providing the route for host endothelial cells.

Although the primary purpose of this study was to differentiate hMSCs into endothelial-like cells, the results also serve as proof of concept for using bone marrowderived hMSCs to create a vascularised graft. Our in vivo study showed that introduction of EL-MSCs in the engineered construct doubles the number of vessels in-growing in the construct 2 weeks after implantation. The fact that HUVECs did not induce vessel in-growth when compared to $\mathrm{C} 2 \mathrm{C} 12$ or $\mathrm{C} 2 \mathrm{C} 12 / \mathrm{MSC}$ seeded constructs indicates that these endothelial cells are not able to create stable vascular structures without the support of other cells, pericytes or smooth muscle cells, which will stabilize newly formed blood vessels. Similar results were obtained by Levenberg et al. [58 where they have shown that the addition of embryonic fibroblasts promotes stable vessel formation. According to our results, EL-MSCs do not require the presence of an additional cell type to improve construct vascularization. Increased level of vascularization is crucial for the implantation of large grafts and the possibility to use the patient's own cells to stimulate such an effect is a promising finding for a number of different applications. Further studies are required to verify whether differentiation of hMSCs prior to application can further improve performance of these cells in peripheral vascular disease (PVD) treatment as our data suggest.

This study also presents the opportunity of using iMSCs as model cells for studying the endothelial differentiation of MSC. This can be a useful tool for further study since it provides cells that are not affected by potential donor variation and isolation procedures.

In summary, hMSCs derived from bone marrow acquire several endothelial-like characteristics when cultured in endothelial cell growth supplement and exposed to shear force and extracellular matrix stimuli. These features include both phenotypical as well as functional characteristics. Furthermore, when applied in vivo, EL-MSCs show greater angiogenic potential than both naïve MSCs as well as truly endothelial cells, HUVECs, that are generally used as golden standard for vascularization studies. 
This study presents a facile protocol for MSC preconditioning that improves in vivo performance of these cells with respect to attracting neovascularization. We believe that this approach has potential applications in tissue engineering and provides a tool for various clinical studies where improved vascularization is desired.

To conclude, training MSCs in vitro can be an efficient way to manipulate the fate of these cells in vivo. 


\subsection{Bibliography}

[1] A. J. Friedenstein, R. K. Chailakhyan, N. V. Latsinik, A. F. Panasyuk, and I. V. Keiliss-Borok. Stromal cells responsible for transferring the microenvironment of the hemopoietic tissues. cloning in vitro and retransplantation in vivo. Transplantation, 17(4):331-40, 1974.

[2] C. G. Bellows and J. E. Aubin. Determination of numbers of osteoprogenitors present in isolated fetal rat calvaria cells in vitro. Dev Biol, 133(1):8-13, 1989.

[3] P. Penfornis and R. Pochampally. Isolation and expansion of mesenchymal stem cells/multipotential stromal cells from human bone marrow. Methods Mol Biol, 698:11-21, 2011.

[4] C. M. Cowan, Y. Y. Shi, O. O. Aalami, Y. F. Chou, C. Mari, R. Thomas, N. Quarto, C. H. Contag, B. Wu, and M. T. Longaker. Adipose-derived adult stromal cells heal critical-size mouse calvarial defects. Nat Biotechnol, 22(5):5607,2004 .

[5] R. O. Oreffo, A. Bennett, A. J. Carr, and J. T. Triffitt. Patients with primary osteoarthritis show no change with ageing in the number of osteogenic precursors. Scand J Rheumatol, 27(6):415-24, 1998.

[6] Z. Miao, J. Jin, L. Chen, J. Zhu, W. Huang, J. Zhao, H. Qian, and X. Zhang. Isolation of mesenchymal stem cells from human placenta: comparison with human bone marrow mesenchymal stem cells. Cell Biol Int, 30(9):681-7, 2006.

[7] Y. C. Chai, S. J. Roberts, E. Desmet, G. Kerckhofs, N. van Gastel, L. Geris, G. Carmeliet, J. Schrooten, and F. P. Luyten. Mechanisms of ectopic bone formation by human osteoprogenitor cells on cap biomaterial carriers. Biomaterials, 33(11):3127-42, 2012.

[8] A. J. Friedenstein, R. K. Chailakhjan, and K. S. Lalykina. The development of fibroblast colonies in monolayer cultures of guinea-pig bone marrow and spleen cells. Cell Tissue Kinet, 3(4):393-403, 1970.

[9] Y. Kanda, T. Hinata, S. W. Kang, and Y. Watanabe. Reactive oxygen species mediate adipocyte differentiation in mesenchymal stem cells. Life Sci, 89(78):250-8, 2011.

[10] S. P. Bruder, N. Jaiswal, and S. E. Haynesworth. Growth kinetics, self-renewal, and the osteogenic potential of purified human mesenchymal stem cells during extensive subcultivation and following cryopreservation. J Cell Biochem, 64(2):278-94, 1997.

[11] S. P. Bruder, A. A. Kurth, M. Shea, W. C. Hayes, N. Jaiswal, and S. Kadiyala. Bone regeneration by implantation of purified, culture-expanded human mesenchymal stem cells. J Orthop Res, 16(2):155-62, 1998. 
[12] R. Siddappa, H. Fernandes, J. Liu, C. van Blitterswijk, and J. de Boer. The response of human mesenchymal stem cells to osteogenic signals and its impact on bone tissue engineering. Curr Stem Cell Res Ther, 2(3):209-20, 2007.

[13] M. F. Pittenger, A. M. Mackay, S. C. Beck, R. K. Jaiswal, R. Douglas, J. D. Mosca, M. A. Moorman, D. W. Simonetti, S. Craig, and D. R. Marshak. Multilineage potential of adult human mesenchymal stem cells. Science, 284(5411):143-7, 1999.

[14] M. Dezawa, H. Ishikawa, Y. Itokazu, T. Yoshihara, M. Hoshino, S. Takeda, C. Ide, and Y. Nabeshima. Bone marrow stromal cells generate muscle cells and repair muscle degeneration. Science, 309(5732):314-7, 2005.

[15] Y. Kuroda, M. Kitada, S. Wakao, K. Nishikawa, Y. Tanimura, H. Makinoshima, M. Goda, H. Akashi, A. Inutsuka, A. Niwa, T. Shigemoto, Y. Nabeshima, T. Nakahata, Y. Fujiyoshi, and M. Dezawa. Unique multipotent cells in adult human mesenchymal cell populations. Proc Natl Acad Sci U S A, 107(19):8639-43, 2010 .

[16] A. S. de la Garza-Rodea, L. van der Velde-van Dijke, H. Boersma, M. A. Goncalves, D. W. van Bekkum, A. A. de Vries, and S. Knaan-Shanzer. Myogenic properties of human mesenchymal stem cells derived from three different sources. Cell Transplant, 2011.

[17] A. Faroni, C. Mantovani, S. G. Shawcross, M. Motta, G. Terenghi, and V. Magnaghi. Schwann-like adult stem cells derived from bone marrow and adipose tissue express gamma-aminobutyric acid type b receptors. J Neurosci Res, 89(9):1351$62,2011$.

[18] M. Albersen, M. Kendirci, F. Van der Aa, W. J. Hellstrom, T. F. Lue, and J. L. Spees. Multipotent stromal cell therapy for cavernous nerve injury-induced erectile dysfunction. J Sex Med, 2011.

[19] C. Steffenhagen, F. X. Dechant, E. Oberbauer, T. Furtner, N. Weidner, P. Kury, L. Aigner, and F. J. Rivera. Mesenchymal stem cells prime proliferating adult neural progenitors toward an oligodendrocyte fate. Stem Cells Dev, 2011.

[20] A. Keating. Mesenchymal stromal cells. Curr Opin Hematol, 13(6):419-25, 2006.

[21] A. Chatterjea, G. Meijer, C. van Blitterswijk, and J. de Boer. Clinical application of human mesenchymal stromal cells for bone tissue engineering. Stem Cells Int, 2010:215625, 2010 .

[22] A. Abdel-Latif, R. Bolli, I. M. Tleyjeh, V. M. Montori, E. C. Perin, C. A. Hornung, E. K. Zuba-Surma, M. Al-Mallah, and B. Dawn. Adult bone marrowderived cells for cardiac repair: a systematic review and meta-analysis. Arch Intern Med, 167(10):989-97, 2007. 
[23] K. C. Wollert, G. P. Meyer, J. Lotz, S. Ringes-Lichtenberg, P. Lippolt, C. Breidenbach, S. Fichtner, T. Korte, B. Hornig, D. Messinger, L. Arseniev, B. Hertenstein, A. Ganser, and H. Drexler. Intracoronary autologous bone-marrow cell transfer after myocardial infarction: the boost randomised controlled clinical trial. Lancet, 364(9429):141-8, 2004.

[24] R. Poulsom, M. R. Alison, T. Cook, R. Jeffery, E. Ryan, S. J. Forbes, T. Hunt, S. Wyles, and N. A. Wright. Bone marrow stem cells contribute to healing of the kidney. J Am Soc Nephrol, 14 Suppl 1:S48-54, 2003.

[25] M. R. Alison, R. Poulsom, R. Jeffery, A. P. Dhillon, A. Quaglia, J. Jacob, M. Novelli, G. Prentice, J. Williamson, and N. A. Wright. Hepatocytes from non-hepatic adult stem cells. Nature, 406(6793):257, 2000.

[26] X. L. Aranguren, C. M. Verfaillie, and A. Luttun. Emerging hurdles in stem cell therapy for peripheral vascular disease. J Mol Med (Berl), 87(1):3-16, 2009.

[27] R. W. Franz, A. Parks, K. J. Shah, T. Hankins, J. F. Hartman, and M. L. Wright. Use of autologous bone marrow mononuclear cell implantation therapy as a limb salvage procedure in patients with severe peripheral arterial disease. J Vasc Surg, 50(6):1378-90, 2009.

[28] C. K. Colton. Implantable biohybrid artificial organs. Cell Transplant, 4(4):41536, 1995.

[29] A. Zumstein, O. Mathieu, H. Howald, and H. Hoppeler. Morphometric analysis of the capillary supply in skeletal muscles of trained and untrained subjects-its limitations in muscle biopsies. Pflugers Arch, 397(4):277-83, 1983.

[30] M. Radisic, W. Deen, R. Langer, and G. Vunjak-Novakovic. Mathematical model of oxygen distribution in engineered cardiac tissue with parallel channel array perfused with culture medium containing oxygen carriers. Am J Physiol Heart Circ Physiol, 288(3):H1278-89, 2005.

[31] H. S. Hung, W. C. Shyu, C. H. Tsai, S. H. Hsu, and S. Z. Lin. Transplantation of endothelial progenitor cells as therapeutics for cardiovascular diseases. Cell Transplant, 18(9):1003-12, 2009.

[32] T. Asahara, T. Murohara, A. Sullivan, M. Silver, R. van der Zee, T. Li, B. Witzenbichler, G. Schatteman, and J. M. Isner. Isolation of putative progenitor endothelial cells for angiogenesis. Science, 275(5302):964-7, 1997.

[33] D. A. Ingram, L. E. Mead, H. Tanaka, V. Meade, A. Fenoglio, K. Mortell, K. Pollok, M. J. Ferkowicz, D. Gilley, and M. C. Yoder. Identification of a novel hierarchy of endothelial progenitor cells using human peripheral and umbilical cord blood. Blood, 104(9):2752-60, 2004. 
[34] H. Masuda, C. Alev, H. Akimaru, R. Ito, T. Shizuno, M. Kobori, M. Horii, T. Ishihara, K. Isobe, M. Isozaki, J. Itoh, Y. Itoh, Y. Okada, B. A. McIntyre, S. Kato, and T. Asahara. Methodological development of a clonogenic assay to determine endothelial progenitor cell potential. Circ Res, 109(1):20-37, 2011.

[35] J. M. Melero-Martin, Z. A. Khan, A. Picard, X. Wu, S. Paruchuri, and J. Bischoff. In vivo vasculogenic potential of human blood-derived endothelial progenitor cells. Blood, 109(11):4761-8, 2007.

[36] G. C. Schatteman and O. Awad. In vivo and in vitro properties of cd34+ and cd14+ endothelial cell precursors. Adv Exp Med Biol, 522:9-16, 2003.

[37] G. C. Schatteman, M. Dunnwald, and C. Jiao. Biology of bone marrow-derived endothelial cell precursors. Am J Physiol Heart Circ Physiol, 292(1):H1-18, 2007.

[38] A. E. Ensley, R. M. Nerem, D. E. Anderson, S. R. Hanson, and M. T. Hinds. Fluid shear stress alters the coagulation potential of endothelial outgrowth cells. Tissue Eng Part A, 2011.

[39] J. Rouwkema, J. de Boer, and C. A. Van Blitterswijk. Endothelial cells assemble into a 3-dimensional prevascular network in a bone tissue engineering construct. Tissue Eng, 12(9):2685-93, 2006.

[40] K. Szoke, K. J. Beckstrom, and J. E. Brinchmann. Human adipose tissue as a source of cells with angiogenic potential. Cell Transplant, 2011.

[41] P. Bianco and P. Gehron Robey. Marrow stromal stem cells. J Clin Invest, 105(12):1663-8, 2000.

[42] K. Bala, K. Ambwani, and N. K. Gohil. Effect of different mitogens and serum concentration on huvec morphology and characteristics: Implication on use of higher passage cells. Tissue Cell, 43(4):216-22, 2011.

[43] T. T. Terramani, D. Eton, P. A. Bui, Y. Wang, F. A. Weaver, and H. Yu. Human macrovascular endothelial cells: optimization of culture conditions. In Vitro Cell Dev Biol Anim, 36(2):125-32, 2000.

[44] N. Yang, D. Li, P. Jiao, B. Chen, S. Yao, H. Sang, M. Yang, J. Han, Y. Zhang, and S. Qin. The characteristics of endothelial progenitor cells derived from mononuclear cells of rat bone marrow in different culture conditions. Cytotechnology, 63(3):217-26, 2011.

[45] P. F. Davies, T. Mundel, and K. A. Barbee. A mechanism for heterogeneous endothelial responses to flow in vivo and in vitro. $J$ Biomech, 28(12):1553-60, 1995.

[46] P. Zhang, J. Baxter, K. Vinod, T. N. Tulenko, and P. J. Di Muzio. Endothelial differentiation of amniotic fluid-derived stem cells: synergism of biochemical and shear force stimuli. Stem Cells Dev, 18(9):1299-308, 2009. 
[47] H. Wang, G. M. Riha, S. Yan, M. Li, H. Chai, H. Yang, Q. Yao, and C. Chen. Shear stress induces endothelial differentiation from a murine embryonic mesenchymal progenitor cell line. Arterioscler Thromb Vasc Biol, 25(9):1817-23, 2005.

[48] K. Yamamoto, T. Sokabe, T. Watabe, K. Miyazono, J. K. Yamashita, S. Obi, N. Ohura, A. Matsushita, A. Kamiya, and J. Ando. Fluid shear stress induces differentiation of flk-1-positive embryonic stem cells into vascular endothelial cells in vitro. Am J Physiol Heart Circ Physiol, 288(4):H1915-24, 2005.

[49] K. Bai, Y. Huang, X. Jia, Y. Fan, and W. Wang. Endothelium oriented differentiation of bone marrow mesenchymal stem cells under chemical and mechanical stimulations. J Biomech, 43(6):1176-81, 2010.

[50] E. Kniazeva, S. Kachgal, and A. J. Putnam. Effects of extracellular matrix density and mesenchymal stem cells on neovascularization in vivo. Tissue Eng Part A, 17(7-8):905-14, 2011.

[51] Y. Cao, Z. Sun, L. Liao, Y. Meng, Q. Han, and R. C. Zhao. Human adipose tissue-derived stem cells differentiate into endothelial cells in vitro and improve postnatal neovascularization in vivo. Biochem Biophys Res Commun, 332(2):3709, 2005.

[52] L. J. Fischer, S. McIlhenny, T. Tulenko, N. Golesorkhi, P. Zhang, R. Larson, J. Lombardi, I. Shapiro, and P. J. DiMuzio. Endothelial differentiation of adiposederived stem cells: effects of endothelial cell growth supplement and shear force. J Surg Res, 152(1):157-66, 2009.

[53] J. Oswald, S. Boxberger, B. Jorgensen, S. Feldmann, G. Ehninger, M. Bornhauser, and C. Werner. Mesenchymal stem cells can be differentiated into endothelial cells in vitro. Stem Cells, 22(3):377-84, 2004.

[54] G. V. Silva, S. Litovsky, J. A. Assad, A. L. Sousa, B. J. Martin, D. Vela, S. C. Coulter, J. Lin, J. Ober, W. K. Vaughn, R. V. Branco, E. M. Oliveira, R. He, Y. J. Geng, J. T. Willerson, and E. C. Perin. Mesenchymal stem cells differentiate into an endothelial phenotype, enhance vascular density, and improve heart function in a canine chronic ischemia model. Circulation, 111(2):150-6, 2005.

[55] J. W. Liu, S. Dunoyer-Geindre, V. Serre-Beinier, G. Mai, J. F. Lambert, R. J. Fish, G. Pernod, L. Buehler, H. Bounameaux, and E. K. Kruithof. Characterization of endothelial-like cells derived from human mesenchymal stem cells. $J$ Thromb Haemost, 5(4):826-34, 2007.

[56] J. Doorn, R. Siddappa, C. van Blitterswijk, and J. De Boer. Forskolin enhances in vivo bone formation by human mesenchymal stromal cells. Tissue Eng Part A, 2011. 
[57] S. K. Both, A. J. van der Muijsenberg, C. A. van Blitterswijk, J. de Boer, and J. D. de Bruijn. A rapid and efficient method for expansion of human mesenchymal stem cells. Tissue Eng, 13(1):3-9, 2007.

[58] S. Levenberg, J. Rouwkema, M. Macdonald, E. S. Garfein, D. S. Kohane, D. C. Darland, R. Marini, C. A. van Blitterswijk, R. C. Mulligan, P. A. D'Amore, and R. Langer. Engineering vascularized skeletal muscle tissue. Nat Biotechnol, 23(7):879-84, 2005.

[59] H. Ning, G. Liu, G. Lin, R. Yang, T. F. Lue, and C. S. Lin. Fibroblast growth factor 2 promotes endothelial differentiation of adipose tissue-derived stem cells. J Sex Med, 6(4):967-79, 2009.

[60] L. G. Rodriguez, X. Wu, and J. L. Guan. Wound-healing assay. Methods Mol Biol, 294:23-9, 2005.

[61] P. Carmeliet. Vegf gene therapy: stimulating angiogenesis or angioma-genesis? Nat Med, 6(10):1102-3, 2000.

[62] T. P. Lozito, J. M. Taboas, C. K. Kuo, and R. S. Tuan. Mesenchymal stem cell modification of endothelial matrix regulates their vascular differentiation. $J$ Cell Biochem, 107(4):706-13, 2009.

[63] D. M. Hoganson, 2nd Pryor, H. I., and J. P. Vacanti. Tissue engineering and organ structure: a vascularized approach to liver and lung. Pediatr Res, 63(5):520-6, 2008.

[64] M. Nomi, A. Atala, P. D. Coppi, and S. Soker. Principals of neovascularization for tissue engineering. Mol Aspects Med, 23(6):463-83, 2002.

[65] S. Rafii and D. Lyden. Therapeutic stem and progenitor cell transplantation for organ vascularization and regeneration. Nat Med, 9(6):702-12, 2003.

[66] A. P. McGuigan, D. A. Bruzewicz, A. Glavan, M. J. Butte, and G. M. Whitesides. Cell encapsulation in sub-mm sized gel modules using replica molding. PLoS One, $3(5): \mathrm{e} 2258,2008$.

[67] L. da Silva Meirelles, A. I. Caplan, and N. B. Nardi. In search of the in vivo identity of mesenchymal stem cells. Stem Cells, 26(9):2287-99, 2008.

[68] M. D. Chamberlain, R. Gupta, and M. V. Sefton. Bone marrow-derived mesenchymal stromal cells enhance chimeric vessel development driven by endothelial cell-coated microtissues. Tissue Eng Part A, 18(3-4):285-94, 2012.

[69] P. Carmeliet, V. Ferreira, G. Breier, S. Pollefeyt, L. Kieckens, M. Gertsenstein, M. Fahrig, A. Vandenhoeck, K. Harpal, C. Eberhardt, C. Declercq, J. Pawling, L. Moons, D. Collen, W. Risau, and A. Nagy. Abnormal blood vessel development and lethality in embryos lacking a single vegf allele. Nature, 380(6573):435-9, 1996. 
[70] A. Eichmann and M. Simons. Vegf signaling inside vascular endothelial cells and beyond. Curr Opin Cell Biol, 2012.

[71] K. Ballmer-Hofer, A. E. Andersson, L. E. Ratcliffe, and P. Berger. Neuropilin1 promotes vegfr-2 trafficking through rab11 vesicles thereby specifying signal output. Blood, 118(3):816-26, 2011.

[72] L. Erskine, S. Reijntjes, T. Pratt, L. Denti, Q. Schwarz, J. M. Vieira, B. Alakakone, D. Shewan, and C. Ruhrberg. Vegf signaling through neuropilin 1 guides commissural axon crossing at the optic chiasm. Neuron, 70(5):951-65, 2011.

[73] M. J. Cross and L. Claesson-Welsh. Fgf and vegf function in angiogenesis: signalling pathways, biological responses and therapeutic inhibition. Trends Pharmacol Sci, 22(4):201-7, 2001.

[74] M. Osawa, M. Masuda, K. Kusano, and K. Fujiwara. Evidence for a role of platelet endothelial cell adhesion molecule-1 in endothelial cell mechanosignal transduction: is it a mechanoresponsive molecule? J Cell Biol, 158(4):773-85, 2002.

[75] A. Gu, W. Tsark, K. V. Holmes, and J. E. Shively. Role of ceacam1 in vegf induced vasculogenesis of murine embryonic stem cell-derived embryoid bodies in 3d culture. Exp Cell Res, 315(10):1668-82, 2009. 



\title{
Chapter 4
}

\section{The effect of donor variation and senescence on endothelial differentiation of human mesenchymal stromal cells}

Karolina Janeczek Portalska, Nathalie Groen, Guido Krenning, Nicole Georgi, Anouk Mentink, Martin C. Harmsen, Clemens van Blitterswijk and Jan de Boer

\begin{abstract}
Application of autologous cells is considered for a broad range of regenerative therapies because it is not surrounded by the immunological and ethical issues of allo- or xenogenic cells. However, isolation, expansion and application of autologous cells does suffer from variability in therapeutic efficacy due to donor to donor differences and due to prolonged culture. One important source of autologous cells are mesenchymal stromal cells (MSCs), which can differentiate towards endothelial-like cells, thus making them an ideal candidate as cell source for tissue vascularization. Here, we screened MSCs from 20 donors for their endothelial differentiation capacity and correlated it with the gene expression profile of the whole genome in the undifferentiated state. Cells of all donors were able to form tubes on Matrigel and induced the expression of endothelial genes, although with quantitative differences. In addition, we analyzed the effect of prolonged in vitro expansion on the multipotency of hMSCs and found that endothelial differentiation is only mildly sensitive to expansion-induced loss of differentiation as compared to osteogenic and adipogenic differentiation. Our results show the robustness of the endothelial differentiation protocol and the gene expression data give insight in the differences in endothelial differentiation between donors.
\end{abstract}




\subsection{Introduction}

The use of allo- and xenogenic cells in regenerative therapies will always entail the possibility of graft rejection and the necessity of applying immunosuppressive therapy, which as a result will be a burden for patients. Therefore, most investigators in the field currently consider autologous cells as the most logical choice for study.

Mesenchymal stromal cells (MSC), a much used source of autologous cells, can be isolated relatively easily from multiple sources including adipose tissue, tibia, femur, lumbar spine and trabecular bone $[1-4]$. They can be then expanded in vitro and are characterized by their multipotency. Among others they can differentiate into the adipogenic, osteogenic and chondrogenic lineages [5, 6]. What is less well documented is the ability of MSCs to differentiate towards other cell types such as skeletal muscle cells and neural cells 7 7 . Moreover, it was shown lately that MSCs can also be a source of endothelial-like cells $10-12$, which would qualify them as candidate cells for therapies aimed at improved tissue vascularization, such as treatment of ischemic tissues and various strategies concerning large graft engineering.

We and others have shown that when human MSCs are grown in endothelial differentiation medium, they express endothelial markers such as CD31, von Willebrand factor and VE-cadherin, both at the mRNA and protein level [10 16. In addition, the actively take up acidic LDL, another hallmark of endothelial cells. When grown on Matrigel, the cells will form tube-like structures. Moreover, when these cells are implanted in immune-deficient animals, CD31 positive human cells can be seen in the vessel wall of perfused blood vessels, demonstrating that human cells can functionally contribute to blood vessels. Nevertheless, further characterization of the cells is needed, and for that reason we refer to the cells as "endothelial-like cells".

In order to apply MSC-derived endothelial-like cells, it is essential to establish a stable protocol for MSC isolation, culture and differentiation, because it will affect the therapeutic effect of the cells, as demonstrated previously for the application of MSCs in bone tissue engineering 17,19 . We have recently described a robust protocol to induce endothelial-like cells from bone marrow-derived MSCs in vitro and demonstrated their ability to contribute to the vasculature upon implantation in a mouse model. What remains to be addressed in order to bring endothelial-like MSCs to the clinic is both the large inter-donor variation in multi-lineage potential [1, 20 and the phenomenon of loss of multipotency upon culture expansion of MSCs. We and others have observed striking differences between hMSCs of different donors with regard to growth rate, expression of both lineage-specific and non-specific markers such as ALP and STRO-1 and their response to in vitro differentiation and ectopic bone formation $[1,2022$. Similar situation can occur upon endothelial differentiation which can explain the controversy concerning the ability of MSCs to acquire endothelial characteristics. A complicating fact is that therapeutic efficacy of MSCs is often not directly linked to marker gene or protein expression in vitro 2325 .

Because the yield of hMSCs upon isolation is very low, expansion in culture is an essential step in their application. Unfortunately, this is associated with culture- 
induced loss of multipotency, as described by several researchers 1, 26]. It was demonstrated that in vitro expanded MSCs acquire a phenotype characterized by loss of multipotency already at early passages 26 28] followed by replicative senescence at later stages of expansion. It appears that a hierarchy exists among the different lineages with respect to the number of population doublings at which loss of the particular differentiation route comes in effect 1,29 .

Although donor variability and loss of multipotency has been well-described for differentiation into the osteo- and adipogenic lineages, no such data is available for endothelial-like differentiation. To address this deficiency we have created a bank of MSCs isolated from 62 donors (patients that were undergoing orthopedic surgery) and collected data about their in vitro expansion and differentiation capacity as well as their gene expression profiles. Using microarray study we have identified a diagnostic bone-forming classifier 22 capable of indicating the in vivo bone-forming capacity of hMSCs from different donors (unpublished data). In this manuscript, we have selected 20 donors of this bank and evaluated their propensity to differentiate into endothelial-like cells in order to sketch inter-donor variability and to evaluate whether gene expression in undifferentiated hMSCs correlated to it. Moreover, we have studied loss of endothelial-like differentiation potential during culture expansion and compared it to loss of adipo- and osteogenic differentiation.

\subsection{Materials and methods}

\subsubsection{Isolation and culture}

Human mesenchymal stromal cells (hMSCs) were isolated from human bone marrow from donors who provided us with written informed consent [30]. Aspirates were resuspended using a $20 \mathrm{G}$ needle and plated at a density 0.5 million mononucleated cells $/ \mathrm{cm}^{2}$. Cells were grown in MSC proliferation medium which contains minimal essential medium (alfa-MEM, GIBCO) supplemented with $10 \%$ fetal bovine serum (FBS, Lonza), $100 \mathrm{U} / \mathrm{ml}$ penicillin (GIBCO), $10 \mu \mathrm{g} / \mathrm{ml}$ streptomycin (GIBCO), $2 \mathrm{mM}$ L-glutamin (GIBCO), $0.2 \mathrm{mM}$ L-ascorbic acid 2-phosphate magnesium salt (ASAp, Sigma Aldrich) and $1 \mathrm{ng} / \mathrm{ml}$ basic fibroblast growth factor (bFGF, Instruchemie) at $37^{\circ} \mathrm{C}$ in a humid atmosphere with $5 \% \mathrm{CO}_{2}$. Cells were expanded up to passage 2. For further experiments hMSCs from 23 different donors and one immortalized clone (iMSCs, courtesy of Ola Myklebost) were cultured in basic medium (alfa-MEM supplemented with $10 \% \mathrm{FBS}, 100 \mathrm{U} / \mathrm{ml}$ penicillin, $10 \mu \mathrm{g} / \mathrm{ml}$ streptomycin, $2 \mathrm{mM} \mathrm{L}$ glutamin, $0.2 \mathrm{mM}$ ASAp). Human umbilical vein endothelial cells (HUVEC, Lonza) were cultured in endothelial growth medium (EGM-2, Lonza).

\subsubsection{ALP analysis}

In order to analyze the activity of alkaline phosphatase, hMSCs from one donor were seeded at a density of 5,000 cells $/ \mathrm{cm}^{2}$ in 6 -well plates. Osteogenic medium (alfaMEM, 10\% FBS, $100 \mathrm{U} / \mathrm{ml}$ penicillin, $10 \mu \mathrm{g} / \mathrm{ml}$ streptomycin, $2 \mathrm{mM}$ L-glutamine, 
0.2 mM ASAp, 0.01 M BGP, 10-8 M dexamethasone) was changed twice a week and cells were cultured for 1 week. ALP activity was analyzed using the Sigma kit \#85 per manufacturer's instructions. Briefly, the culture medium was aspirated, cells were washed twice with calcium and magnesium free PBS and fixed in acetone/citrate. After washing in deionized water cells were stained with Fast Blue RR/naphthol. As a result naphthol AS-MX is liberated and immediately coupled with a diazonium salt forming an insoluble, visible pigment at sites of phosphatase activity. Cells were photographed using a Nikon SMZ 10A camera.

To confirm the results, an ALP biochemical assay (CDP-Star, Roche) was performed on selected samples. Briefly, cells were washed with PBS and lysed with lysis buffer (100mM potassium phosphate, $\mathrm{pH} 7.8,0.2 \%$ Triton-X-100) for $10 \mathrm{~min}$ at room temperature. $10 \mu \mathrm{l}$ of the lysate was put in an optiplate together with $40 \mu \mathrm{l}$ of CDPStar, incubated for $30 \mathrm{~min}$ in darkness at room temperature and then measured with a Victor Light Luminescence Plate Reader (Perkin Elmer).

\subsubsection{Adipogenesis}

Adipogenic differentiation capacity of hMSCs was determined as described previously [31]. Briefly, cells from one donor were cultured for three weeks in adipogenic medium (DMEM, 10\% FBS, $100 \mathrm{U} / \mathrm{ml}$ penicillin, $10 \mu \mathrm{g} / \mathrm{ml}$ streptomycin, $0.5 \mathrm{mM}$ IBMX, $1 \mu \mathrm{M}$ dexamethasone, $10 \mu \mathrm{M}$ insulin, $200 \mu \mathrm{M}$ indomethacin). After that, lipid formation was visualized by staining with Oil red O. Cells were photographed using a Nicon Eclipse TE300 and the adipocytes were counted in the picture frame. At least 3 different locations of each well were included in the quantification.

\subsubsection{Endothelial induction of MSCs}

hMSCs from passage 3 and iMSCs from passage 25 were used for endothelial induction protocol as described previously [10. Briefly, cells were seeded at a density of 3,000 cells $/ \mathrm{cm}^{2}$ on tissue culture plastic in EGM-2 and cultured for 10 days. After one day in static culture, shear force was applied using an orbital shaker. For induction on Matrigel, wells on 6-well plates were covered with $1 \mathrm{ml}$ of growth factor reduced Matrigel (BD Bioscience) diluted 1:1 in EGM-2 without growth factors. Cells were seeded at the density of 30,000 cells per $\mathrm{cm}^{2}\left(60,000\right.$ cells per $\mathrm{cm}^{2}$ in case of HUVECs due to their smaller size) and cultured in a humid atmosphere with $5 \% \mathrm{CO}_{2}$. After 24 hours of culture on Matrigel hMSCs start to express endothelial markers and are referred to as endothelial-like MSCs (EL-MSCs).

\subsubsection{Matrigel assay}

The assay was performed as described above. The formation of capillary-like structures (CLS) on Matrigel was observed over time using an inverted microscope (Nikon Eclipse TE300). Cells from all 20 donors were used in this study. Pictures were taken at different time points $(4,8,16,24,48$, and 96 hours after seeding) using a Nikon DS-L2 camera. The experiment was performed in triplicate. 


\subsubsection{TubeCount}

Capillary-like structure formation was quantified based on images taken at a 24hour time point using TubeCount software, as described previously [10]. As a result we gathered valuable statistics such as total and average tube length, average tube width, number of tube branching points and total tube area. A minimal number of 3 pictures per condition were analyzed.

\subsubsection{RNA isolation and quantitative PCR}

Total RNA was isolated using TRIZOL reagent according to manufacturer's protocol. In short, $1 \mathrm{ml}$ of Trizol reagent was added per T25 flask (cells cultured in basic medium) or per well (cells cultured on Matrigel in 6-well plates). Samples were incubated for $5 \mathrm{~min}$ at room temperature to allow complete dissociation, and phase separation was performed by adding chloroform. After that samples were centrifuged at $12,000 \mathrm{x}$ g for $15 \mathrm{~min}$. RNA was precipitated by mixing the aqueous phase with isopropyl alcohol followed by 10 min incubation at room temperature. Samples were centrifuged again and the remaining RNA pellet was washed with $75 \%$ ethanol. The obtained samples were dissolved in water, and after that the quantity and quality of RNA was analyzed using spectrophotometry (ND-1000 spectrophotometer). OD $260 / 280 \mathrm{~nm}$ ratios $>1.8$ were observed for all samples indicating high purity.

$500 \mathrm{ng}$ of RNA was used for first strand cDNA synthesis using Superscript II (Invitrogen) according to the manufacturer's protocol. One $\mu \mathrm{l}$ of $3 \mathrm{x}$ diluted cDNA was used for PCRs performed in a Light Cycler real time PCR machine (BioRad). Data was analyzed using Bio-Rad iQ5 software and expression of endothelial genes was calculated relative to GAPDH levels by the comparative $\triangle \mathrm{CT}$ method 32 . Primers used in the study are: Platelet Endothelial Cell Adhesion Molecule-1 (CD31) F 5 ' TCTATGACCTCGCCCTCCACAAA 3', R 5' GAACGGTGTCTTCAGGTTGGTATTTCA 3'; VEGF receptor 2 (KDR) F 5' ACTTTGGAAGACAGAACCAAATTATCTC 3', R 5' TGGGCACCATTCCACCA 3'; von Willebrand factor (vWF) F 5' TGCTGACACCAGAAAAGTGC 3', R 5' AGTCCCCAATGGACTCACAG 3'; GAPDH F 5' CGCTCTCTGCTCCTCCTGTT 3', R 5' CCATGGTGTCTGAGCGATGT 3'.

\subsubsection{Microarray analysis}

To analyse the gene expression profile of hMSCs, microarray analysis was used. RNA was hybridized to the Human Genome U133A 2.0 Array (Affymetrix) and scanned with a GeneChip G3000 scanner (Affymetrix). To normalize the measurements, we used a normalization method which removes hybridization, amplification and array location based technical effects. Further data analysis and statistical testing were performed using $\mathrm{R}$ and Bioconductor statistical software (http: //www.bioconductor.org/). A linear modelling approach with empirical Bayesian methods, as implemented in Limma package 33], was used to determine differential gene expression. To analyse the donor variation in terms of endothelial differentiation ability, we scored the different donor-derived MSCs based on their CD31 expression 
on one hand and KDR expression on the other hand. Subsequently, a list of genes ranked on fold change between the best and poorest endothelial differentiating donors was generated.

\subsubsection{Statistics}

Each experiment was performed in triplicate. Data that required multiple comparison test was analyzed in SPSS (PASW statistics) using one-way Anova followed by Tukey's multiple comparison test $(\mathrm{P}<0.05)$. Error bars on graphs represent standard deviation.

\subsubsection{Ethics statement}

Human mesenchymal stromal cells (hMSCs) were isolated from human bone marrow from donors with written informed consent. This study was carried out in strict accordance with the recommendations of the Medisch Ethische Toetsings Commissie Twente (Medical Ethical Research Committee Twente) and was approved by this Committee.

\subsection{Results}

\subsection{1 hMSC characterization}

hMSC from our bank of 62 donors have been characterized previously (unpublished data) according to the set of standards proposed by the Mesenchymal and Tissue Stem Cell Committee of the International Society for Cellular Therapy [34. In this manuscript, we have randomly selected 20 donors from the donor bank [1]. After defrosting and brief expansion, a subsection of cells of all donors were subjected to osteogenic and adipogenic differentiation. As shown in Figure 4.1. MSCs from all donors readily acquired properties of adipocytes or osteoblast respectively, demonstrating their multipotency.

\subsubsection{Effect of culture expansion on multipotency of hMSCs}

We previously showed 1 that efficient differentiation of hMSCs is limited after prolonged expansion in vitro. To confirm these results, osteogenic and adipogenic differentiation of hMSCs from one donor was evaluated over 10 passages. Similar to previous observations, changes in cell morphology occurred during prolonged in vitro expansion (Figure 4.2 A). hMSCs between passage 7 and 10 lost their fibroblast-like shape and acquired a more spread morphology. The cells in culture became larger, with irregular and heterogeneous contours. Moreover, hMSCs expanded in vitro lost their proliferation capacity over time, being unable to reach confluency even after prolonged culture (data not shown).

To document osteogenesis, we measured dexamethasone-induced activity of the bone-maker alkaline phosphatase (ALP) [1]. Cells from passage 1 showed a 3 times higher activity of ALP than cells from passage 2 to 5 (Figure 4.2 B) and ALP activity 
A
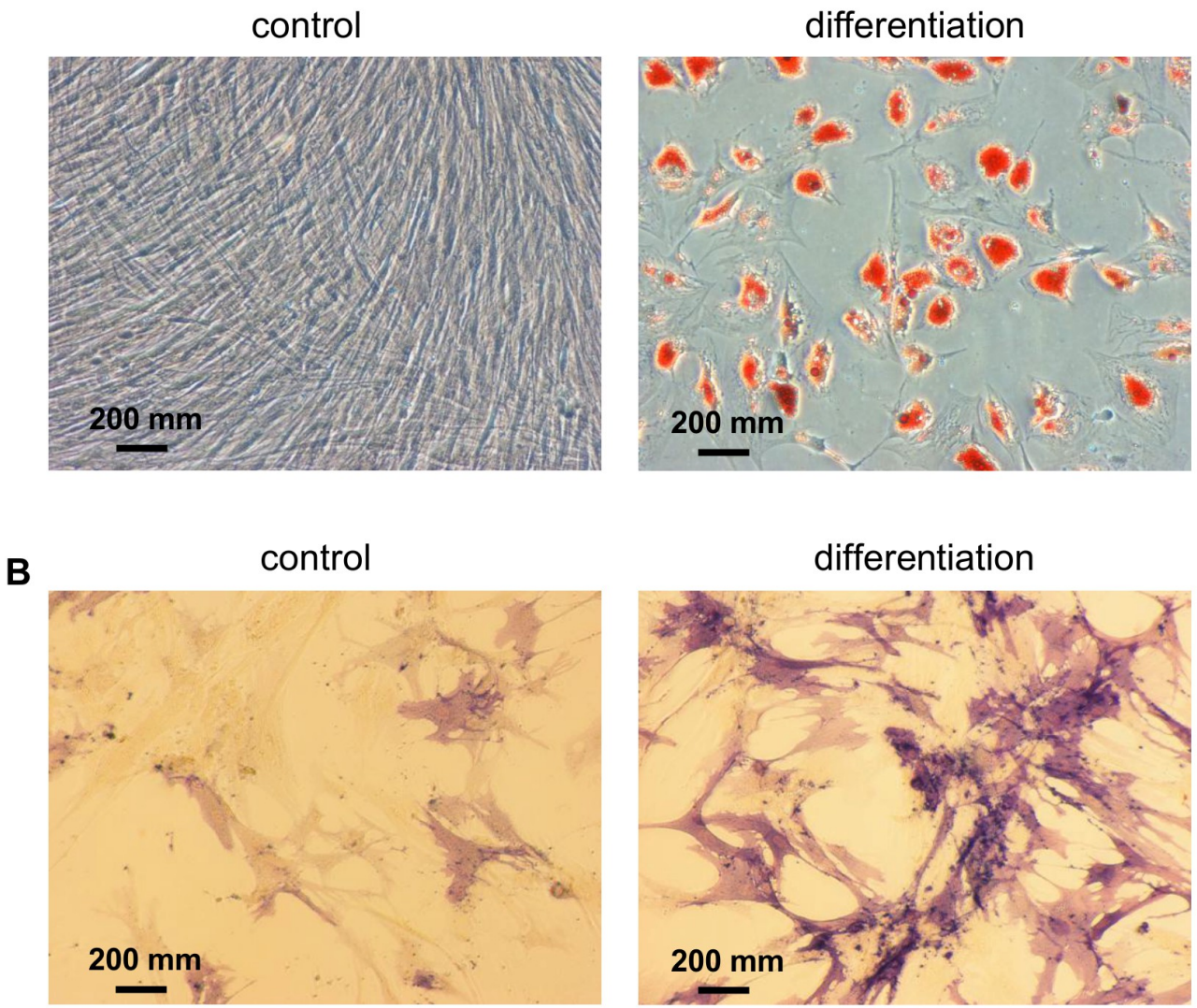

Figure 4.1: Pluripotency of hMSCs. Adipogenic differentiation (A) demonstrated by Oil red O staining and osteogenic differentiation (B) demonstrated by ALP staining.

declined again three-fold in cells from passage 6 and higher (Figure 4.2B). A similar trend was observed for adipogenic differentiation (Figure $4.3 \mathrm{~A}$ ), where cells from passage 1 differentiated more efficiently than cells from passage 2 to 7 . A gradual loss of adipogenic potential was observed (Figure $4.3 \mathrm{~B}$ ). Next, we evaluated whether the endothelial differentiation capacity of hMSCs was lost as well upon culture expansion. In this case, we expanded cells from 2 donors (D42, D56) and first looked at their capacity to form tubes on Matrigel (Figure 4.4A). Overall, MSCs did not lose their capacity to form tubes, up to passage 7 . At higher passages, we were unable to retrieve sufficient number of cells to perform the assay. In the case of donor 42, prolonged expansion led to shorter capillary-like structures, although the number of branching points seemed to increase. With cells from donor 56, we observed the opposite, with 
A
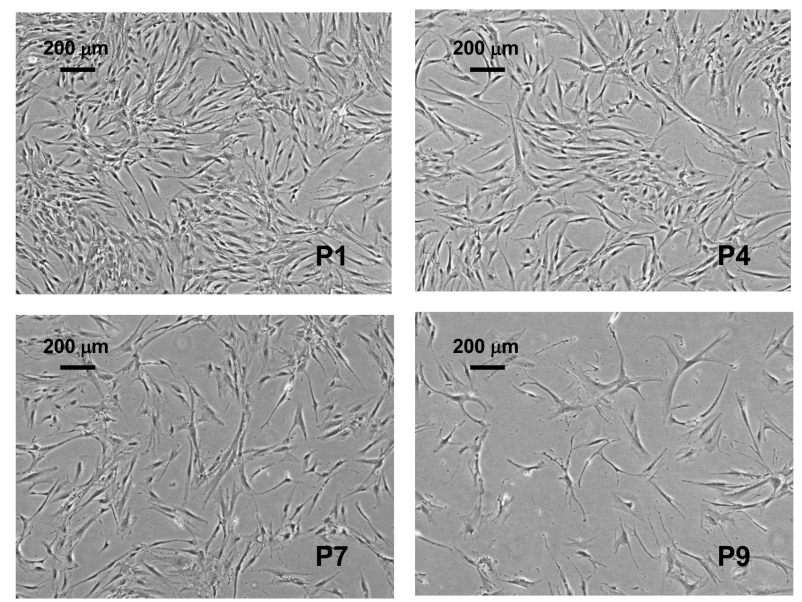

B

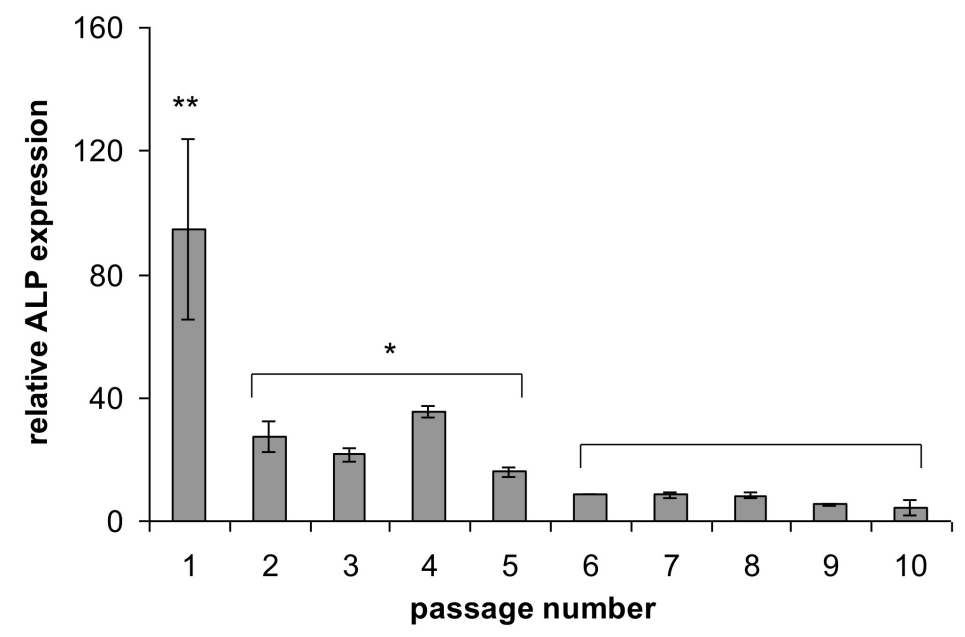

Figure 4.2: Expansion and osteogenic potential of serially passaged hMSCs. Cell morphology (A). CDP-Star assay was used to quantify ALP activity (B). Error bars represent standard deviation, ${ }^{*}$ and ${ }^{* *}$ denote statistical significance towards other groups $(\mathrm{p}<0.05)$.

longer capillary like structure and fewer branching point at high passages. As a second readout of endothelial differentiation, we measured the expression of the endothelial marker CD31 in hMSCs exposed to proliferation medium and endothelial differentiation medium of three donors at various passage numbers. At passage 3, we observed induction of CD31 in all three donors, but this was completely lost in donor 57. Surprisingly, the cells of the other two donors were still able to induce CD31 expression at passage 7 , and even with a higher fold induction than at passage 3 (Figure $4.4 \mathrm{~B}$ ). 
Our data show that endothelial differentiation is not as sensitive to culture-induced loss of differentiation capacity as adipogenic and osteogenic differentiation are.

A
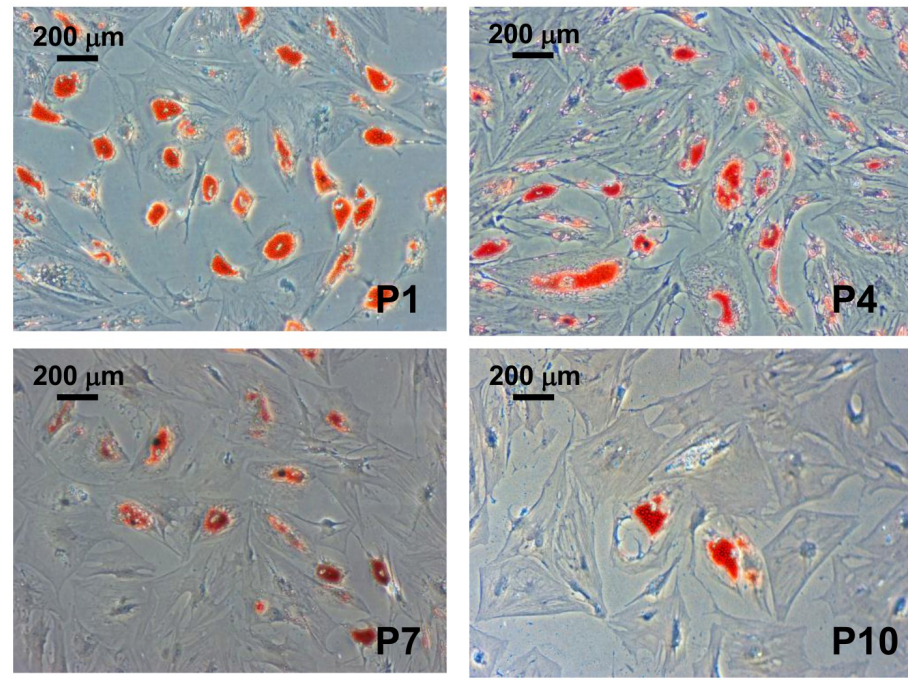

B

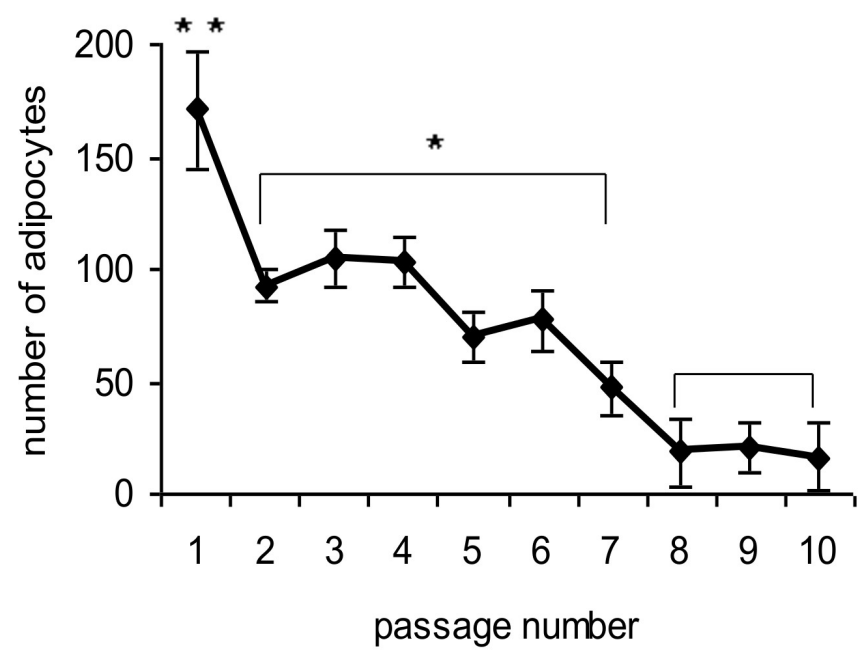

Figure 4.3: Adipogenic potential of serially passaged hMSCs. Adipogenic differentiation was visualized by staining with Oil red $\mathrm{O}(\mathrm{A})$ and the number of adipocytes was quantified (B). Error bars represent standard deviation, ${ }^{*}$ and $* *$ denote statistical significance towards other groups $(\mathrm{p}<$ $0.05)$. 
A
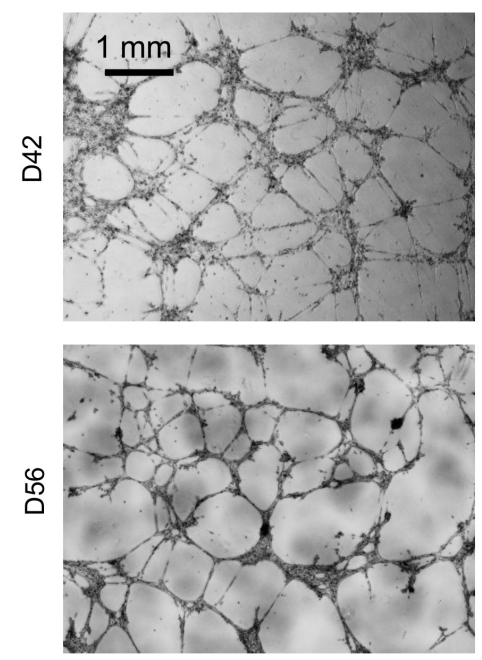

P7
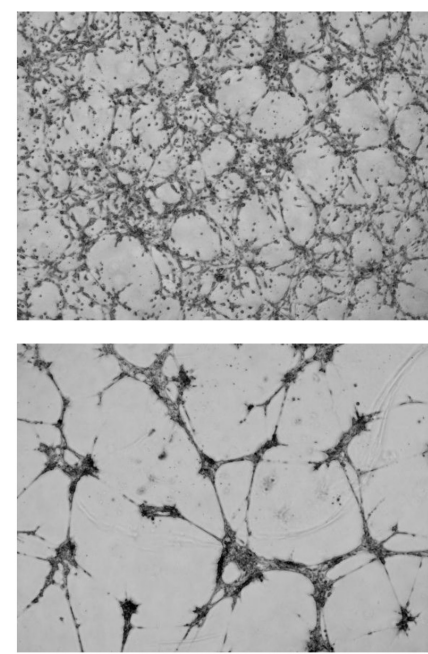

B

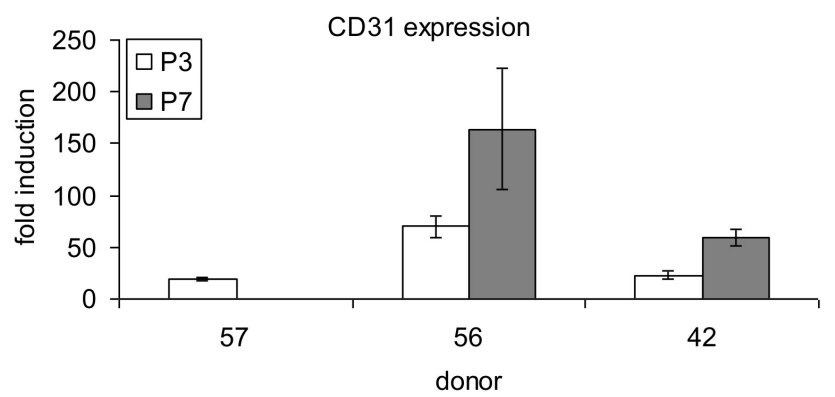

Figure 4.4: Endothelial potential of serially passaged hMSCs. Capillary-like structure formation was observed on Matrigel (A). CD31 expression was compared using qPCR (B). Error bars represent standard deviation.

\subsubsection{Endothelial differentiation of hMSCs}

To investigate whether hMSC source (donor) influences endothelial differentiation, capillary-like structure formation was observed on Matrigel. Tube formation was recorded by phase contrast microscopy and pictures were used for further study. As shown in Figure 4.5A, cells from different donors performed with very different outcome. The quantification of CLS formation was performed using in-house developed TubeCount software. HUVECs were used as positive control in this assay and had a total tube length per analyzed area of $30 \mathrm{~mm}$ and more than 70 branching points. 
Measurement of these parameters with MSCs of 20 donors (Figure 4.5B) revealed that cells from all donors were able to form tube-like structures although substantial inter-donor variation was seen, ranging from equal efficiency as HUVECS to donors of whom the cells produced five-fold less tubes. It also occurred to us that cells from some donors started to form capillary-like structures at a later time point than most, but in the end reached the same level of CLS formation (data not shown). Overall, the total tube length and the number of branching points correlated to each other. Since all results were taken at an arbitrarily chosen time point (24h) identical in case of all analyzed samples, this variability is present in the final quantification. Taken together, our data shows that cells from all donors responded to the Matrigel stimulation but with different efficiency. Yet, there was not a single donor from whom the cells did not respond at all.

\subsubsection{Endothelial gene expression profile in MSCs}

For further classification of EL-MSCs from different donors we analyzed endothelialspecific genes expression. As previously, cells were cultured for 10 days in EGM2 on an orbital shaker and were then reseeded on Matrigel for another 24 hours. This relative short time of culture was chosen because in some cases, the Matrigel coating was completely resorbed at later time points, indicating donor specific matrix degrading activity. We performed qPCR on platelet endothelial cell adhesion molecule (CD31), vascular endothelial growth factor receptor 2 (KDR), von Willebrand factor (vWF) and vascular endothelial Cadherin (VE-Cadherin) and expressed it relative to GAPDH. We found a great variability of endothelial marker induction in cells from different donors. Cells from all donors responded to the differentiation protocol with increased CD31 expression (Figure 4.6A), with a fold induction between 3 and 78. In fifteen donors out of twenty we observed increased KDR expression (fold induction between 16 and 1000) and twelve of the 20 donors showed increased vWF expression (fold induction between 2 and 18) (Figure 4.6B and 4.6 C). Only six donors responded with significantly increased VE-Cadherin expression (fold induction between 32 and 88) (Figure 4.6D). Not in all donors VE-cadherin expression was matched by other markers and we did not observe a robust correlation between total tube length or number of branching points and endothelial marker expression. The expression levels of all tested endothelial markers except KDR did not reach the level of its expression in HUVECs, however, we confirmed in our previous study with immunostainings [10], that these expression levels were relevant.

For further analysis we divided twenty donors into four groups, scoring their endothelial differentiation capability based on changes in CD31 and KDR expression: $25 \%$ of worst performing donors received grade 1 , next $25 \%$ grade 2 , third group grade 3 and the best performing $25 \%$ donors received grade 4 (Table 4.1 . These groups of samples allowed to discriminate between bone marrow-derived hMSCs able to differentiate efficiently into the endothelial lineage (grade 4) from hMSCs that do not have this differentiation capacity (grade 1) and were further used to find differences in gene expression of hMSCs at proliferating state. 
A
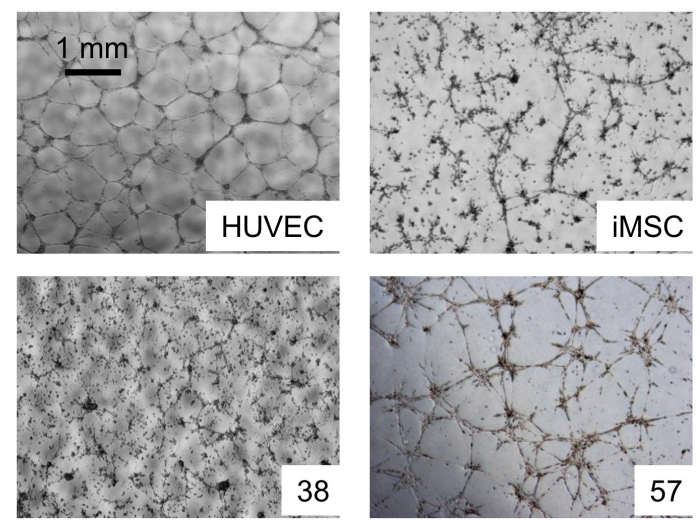

B

Total tube lenght

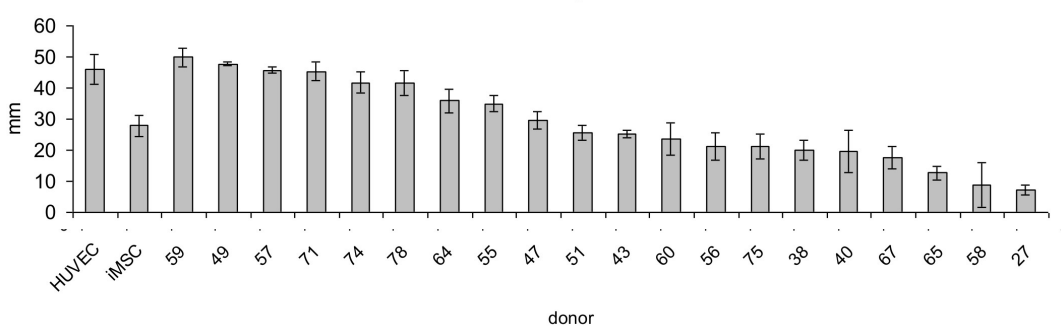

Branching points

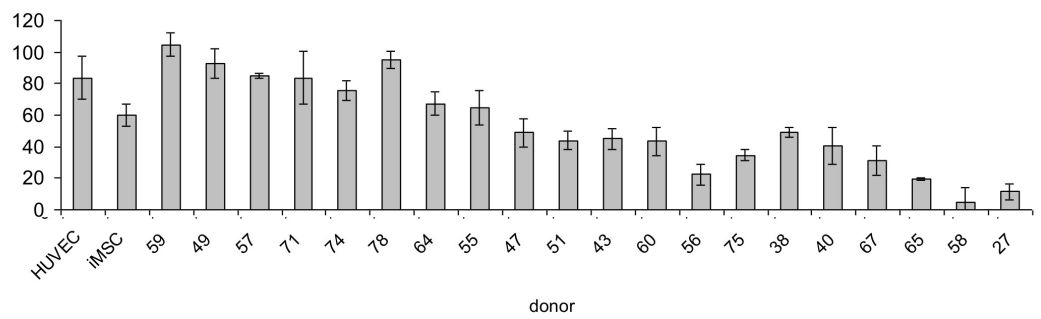

Figure 4.5: Tube assay on Matrigel. EL-hMSCs from different donors were cultured on Matrigel for 24h in EGM-2 medium (A). Total tube length and number of branching points were compared (B).

\subsubsection{Correlation between gene expression profile and ability to show endothelial gene expression}

We investigated whether the differential expression of marker genes in endothelial-like cells is reflected in the gene expression repertoire of their undifferentiated ancestors, in other words we tried to find genes predictive of the efficacy of induction of endothelial 
A

CD31 expression

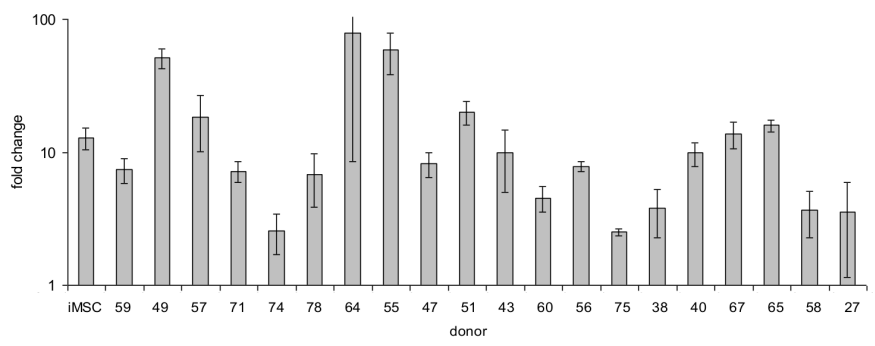

B

KDR expression

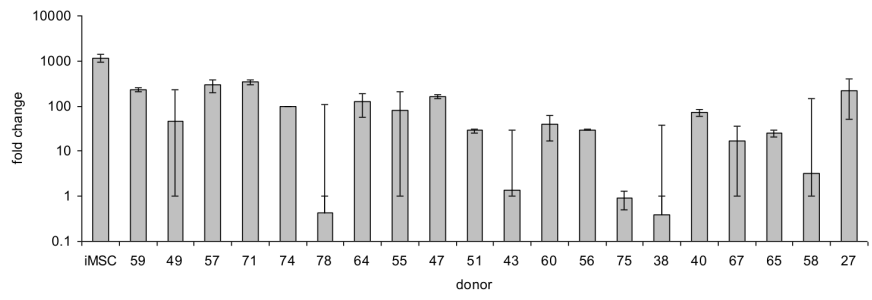

C

WWF expression

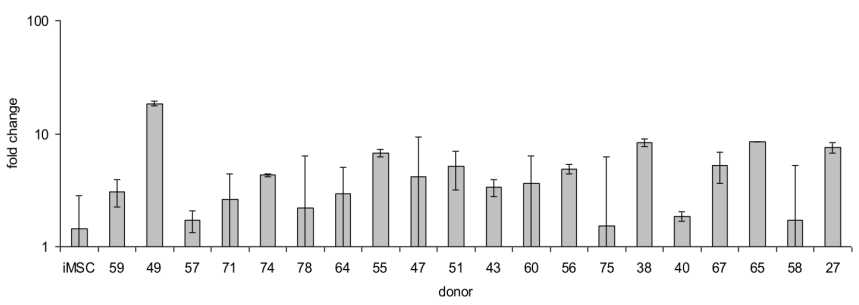

D

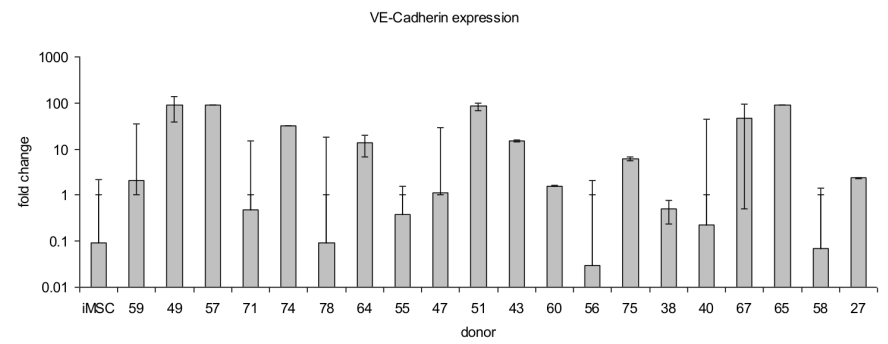

Figure 4.6: Donor variation in endothelial gene expression. Data are represented as fold induction compared to gene expression level of undifferentiated MSCs from the same donor. 


\begin{tabular}{|cccc|}
\hline donor & CD31 & donor & KDR \\
\hline 57 & 4 & 71 & 4 \\
64 & 4 & 64 & 4 \\
49 & 4 & 59 & 4 \\
55 & 4 & 57 & 4 \\
51 & 4 & 47 & 4 \\
67 & 4 & 27 & 4 \\
47 & 3 & 74 & 3 \\
40 & 3 & 55 & 3 \\
65 & 3 & 49 & 3 \\
43 & 3 & 40 & 3 \\
71 & 2 & 67 & 2 \\
59 & 2 & 65 & 2 \\
56 & 2 & 60 & 2 \\
60 & 2 & 56 & 2 \\
78 & 2 & 51 & 2 \\
27 & 1 & 78 & 1 \\
74 & 1 & 75 & 1 \\
38 & 1 & 58 & 1 \\
58 & 1 & 43 & 1 \\
75 & 1 & 38 & 1 \\
\hline
\end{tabular}

Table 4.1: Donor comparison based on qPCR data. Grades were calculated based on the data distribution: $25 \%$ of worst performing donors received grade 1 , next $25 \%$ grade 2 , third group grade 3 and best $25 \%$ donors received grade 4 .

marker gene expression. To this end, we compared the expression profiles of MSCs between the four different groups defined above. The top 30 genes from the resulting list were ranked on $\mathrm{p}$ value (Table 4.2). Interestingly, among the listed genes we found three that are directly involved in VEGF signaling pathway: CRYAB, EGR3, IL7R; four that are typical for endothelial cells: GFPT2, EGR3, ILR7, MEIS2; four involved in the proliferation and migration of cancer cells: SULF1, CRYZ, CA12, PHLDA1 and six involved in cardiovascular system development and diseases: ELN, CRYAB, SLC5A3, CA12, PHLDA1, FHL1 (Table 4.3).

\subsection{Discussion}

Human mesenchymal stromal cells are multipotent cells with well acknowledged capacity to differentiate into cell types from several lineages $5,7,35,36$, 3nd have therefore been extensively tested in various tissue engineering applications. One of the important questions that appear concerning the application of differentiated MSCs is the true nature of cells obtained upon various differentiation protocols. MSCs have been shown to differentiate towards various cell types based both on the expression 


\begin{tabular}{|c|c|c|}
\hline Gene name & Gene Symbol & Fold Change \\
\hline \multicolumn{3}{|l|}{ genes identified based on CD31 expression } \\
\hline elastin & ELN & -2.05 \\
\hline sulfatase 1 & SULF1 & -1.77 \\
\hline crystallin, zeta (quinone reductase) & CRYZ & 1.62 \\
\hline crystallin, alpha B & CRYAB & -1.54 \\
\hline chromosome 1 open reading frame 54 & C1orf54 & 1.46 \\
\hline $\begin{array}{l}\text { solute carrier family } 5 \text { (sodium/myo-inositol cotrans- } \\
\text { porter), member } 3\end{array}$ & SLC5A3 & 1.45 \\
\hline carbonic anhydrase XII & CA12 & 1.45 \\
\hline glutamine-fructose-6-phosphate transaminase 2 & GFPT2 & 1.44 \\
\hline pleckstrin homology-like domain, family A, member 1 & PHLDA1 & 1.44 \\
\hline early growth response 3 & EGR3 & 1.44 \\
\hline carbonic anhydrase XII & CA12 & 1.37 \\
\hline elastin & $\mathrm{ELN}$ & -1.33 \\
\hline $\begin{array}{l}\text { solute carrier family } 16 \text {, member } 4 \text { (monocarboxylic acid } \\
\text { transporter } 5 \text { ) }\end{array}$ & SLC16A4 & 1.31 \\
\hline interleukin 7 receptor & IL7R & -1.26 \\
\hline $\begin{array}{l}\text { adenosine deaminase, RNA-specific, B1 (RED1 homolog } \\
\text { rat) }\end{array}$ & ADARB1 & -1.26 \\
\hline stomatin & STOM & -1.25 \\
\hline $\begin{array}{l}\text { haloacid dehalogenase-like hydrolase domain containing } \\
1 \mathrm{~A}\end{array}$ & HDHD1A & -1.23 \\
\hline serine incorporator 5 & SERINC5 & 1.23 \\
\hline iduronate 2 -sulfatase & IDS & 1.21 \\
\hline kazrin & $\mathrm{KAZ}$ & -1.21 \\
\hline \multicolumn{3}{|l|}{ genes identified based on KDR expression } \\
\hline four and a half LIM domains 1 & FHL1 & -1.79 \\
\hline four and a half LIM domains 1 & FHL1 & -1.74 \\
\hline keratin 19 & KRT19 & 1.69 \\
\hline KIAA1199 & KIAA1199 & -1.45 \\
\hline ferritin, heavy polypeptide 1 & FTH1 & -1.40 \\
\hline glutaminase & GLS & -1.28 \\
\hline Meis homeobox 2 & MEIS2 & 1.28 \\
\hline ATPase, class V, type 10D & ATP10D & -1.21 \\
\hline endothelin receptor type $\mathrm{A}$ & EDNRA & 1.18 \\
\hline structural maintenance of chromosomes 2 & $\mathrm{SMC} 2$ & 1.18 \\
\hline
\end{tabular}

(-) in the fold change value denotes down-regulation when comparing donors with good and poor endothelial differentiation capabilities

Table 4.2: Differentially expressed genes as identified by whole genome expression analysis. Donors were grouped based on their ability to differentiate into endothelial-like cells. Fold change between the best and poorest endothelial differentiating donors (based on CD31 and KDR expression) is specified in the table. Repeated gene names that appear in the table correspond to various probes for the same gene.

of characteristic markers in vitro as well as on their ability to regenerate specific tissues in vivo. Still, the mechanism lying behind the ability of implanted MSCs to regenerate or improve regeneration of various tissues is not fully explored [37]. In our previous work 10, we demonstrated that MSCs can differentiate towards endotheliallike cells. We based this conclusion on both the increased expression of endothelial markers in EL-MSCs, confirmed additionally by immunostainings, and on the effect 
on construct vascularization when EL-MSCs were implanted. Nonetheless, we did not claim to obtain endothelial cells from MSCs but rather cells that are able to replace them in therapeutic applications. To prove the usefulness of the developed protocol, its robustness must be showed with respect to overpowering the variability among cells obtained from different donors.

In this study we isolated and characterized hMSCs from 20 independent donors. First we analyzed cell performance in a Matrigel assay where we found that the efficiency in tube formation was not the same between different donors. According to our observations at various time points (data not shown), some of the differences in results could be caused by the chosen observation time that was set for 24 hours after seeding. Since cells from different donors started to form CLSs at different time points, the results were not fully reflecting the absolute potential of hMSCs to form CLSs. The differences between donors occurred rather as a result of differences in the speed of attachment and migration. CLS network formation on Matrigel occurs as an effect of cells attaching to the gel surface, spreading and getting in contact with each other and with extracellular matrix (ECM). Since the cells used in this assay were freshly trypsinized differences were likely to occur at the level of molecules responsible for ECM binding on the cell surface. Therefore, it was to be expected that the speed of attachment may vary depending on the sample. Another reason for the differences in the speed of cell attachment and migration can be explained by the age of the donors, as Kasper et al. 67] demonstrated that those parameters are strongly correlated. Although donor variation in CLS formation was observed, CLS maturity was reached in all cases within 24 hours. Endothelial cells of all origins are able to form tubules spontaneously 68] but the exact time of this event can be different for various cells of this type 69]. Thus, since EL-MSCs from all investigated donors responded to Matrigel stimulation, the differences in time of response does not mean that those cells did not undergo endothelial differentiation.

Next we analyzed the gene expression profile of differentiated hMSCs with respect to expression of endothelial markers: CD31, KDR, vWF and VE-Cadherin. Here we found great variability of endothelial marker induction in cells from different donors. Up-regulation in the expression of one selected gene was not necessarily followed by up-regulation of the others. This phenomenon could be explained by the single time point that we have chosen for analysis. Cells form various donors were most likely at different level of differentiation after 24 hours of Matrigel culture. As demonstrated by Levenberg at al. 70, the expression of endothelial specific genes in differentiating cells is not correlated with each other in time. Therefore, for microarray studies we decided to focus on these two genes, namely CD31 and KDR, which are commonly used as endothelial markers and for which up-regulation occurred in most of the donors.

Based on the performed microarray study we selected 30 genes that were differentially expressed. Among those we identified 17 genes whose expression is involved in VEGF signaling, expression of markers typical for endothelial cells, development and diseases of cardiovascular system as well as cell proliferation and migration in malignant cancers. hMSCs from various donors have in general a similar gene expres- 


\begin{tabular}{|c|c|c|}
\hline Gene Symbol & Gene name and function & References \\
\hline \multicolumn{3}{|c|}{ VEGF signaling } \\
\hline CRYAB $\downarrow$ & $\begin{array}{l}\text { Crystallin alpha B, protects VEGF from proteolytic degradation, } \\
\text { knockdown of CRYAB had an inhibitory effect on endothelial cells } \\
\text { survival, mutations in the Cryab gene are associated with a broad } \\
\text { variety of neurological, cardiac and muscular disorders }\end{array}$ & 38 \\
\hline EGR3 $\uparrow$ & $\begin{array}{l}\text { Early growth response } 3 \text {, plays a role in endothelial cell growth and } \\
\text { migration, mediates VEGF activation in endothelial cells }\end{array}$ & 40 \\
\hline IL7R $\downarrow$ & $\begin{array}{l}\text { Interleukin } 7 \text { receptor, present on human microvascular endothelial } \\
\text { cells, activation by IL } 7 \text { enhances endothelial cell growth, migration } \\
\text { and generation of lymphatic tubules via upregulating the expression } \\
\text { of the lymphangiogenic growth factor and vascular endothelial growth } \\
\text { factor-D, IL-7 regulates also VEGF-D in lung cancer cell lines, plays a } \\
\text { role in rheumatoid arthritis angiogenesis, and can mediate rheumatoid } \\
\text { arthritis pathogenesis }\end{array}$ & 42,46 \\
\hline \multicolumn{3}{|c|}{ Characteristic for endothelial cells } \\
\hline GFPT2 $\uparrow$ & $\begin{array}{l}\text { Glutamine-fructose-6-phosphate transaminase } 2 \text {, highly active in all } \\
\text { endothelial cells, expressed in most tissues involved in the develop- } \\
\text { ment of diabetic late complications }\end{array}$ & $\overline{47}$ \\
\hline EGR3 $\uparrow$ & See above & \\
\hline IL7R $\downarrow$ & See above & \\
\hline MEIS2 $\uparrow$ & $\begin{array}{l}\text { Meis homeobox } 2 \text {, differentially expressed in placental microvascular } \\
\text { endothelial cells compared with macrovascular cells, possible role in } \\
\text { the development of cleft palate and cardiac septum }\end{array}$ & 4950 \\
\hline \multicolumn{3}{|c|}{ Cell survival, proliferation, migration and cancer malignancy } \\
\hline SULF1 $\downarrow$ & $\begin{array}{l}\text { Sulfatase } 1 \text {, selectively removes } 6 \text {-O-sulfate groups from heparan sul- } \\
\text { fate proteoglycans and by that alters binding sites for various cy- } \\
\text { tokines and growth factors }\end{array}$ & $\overline{51}$ \\
\hline $\mathrm{CRYZ} \uparrow$ & $\begin{array}{l}\text { Crystallin zeta (quinone reductase), enzyme with NADPH-dependent } \\
\text { quinone reductase activity, involved in antiapoptotic bcl-2 overexpres- } \\
\text { sion }\end{array}$ & \begin{tabular}{|l|l|}
39 & 54 \\
\end{tabular} \\
\hline $\mathrm{CA} 12 \uparrow$ & $\begin{array}{l}\text { Carbonic anhydrase XII, zinc metalloenzyme that catalyzes the re- } \\
\text { versible hydration of carbon dioxide, expressed at high levels on var- } \\
\text { ious types of cancer cells including cancer stem cells, involved in tu- } \\
\text { mour progression, additionally contributes to various other diseases } \\
\text { like glaucoma and arteriosclerotic plaques, abundantly expressed in } \\
\text { normal human corneal endothelium }\end{array}$ & $55-58$ \\
\hline PHLDA1 $\uparrow$ & $\begin{array}{l}\text { Pleckstrin homology-like domain, family A, member } 1 \text {, Apoptosis- } \\
\text { associated nuclear protein, contributes to migration and proliferation } \\
\text { in colon cancer cells, contributes to the development of atherosclerosis } \\
\text { observed in hyperhomocysteinemia }\end{array}$ & 5960 \\
\hline \multicolumn{3}{|c|}{ Cardiovascular system development and diseases } \\
\hline ELN $\downarrow$ & $\begin{array}{l}\text { Elastin, components of elastic fibers, disrubtion leads to various vas- } \\
\text { cular diseases }\end{array}$ & $\overline{61}$ \\
\hline CRYAB $\downarrow$ & See above & \\
\hline SLC5A3 $\uparrow$ & $\begin{array}{l}\text { Solute carrier family } 5 \text { (sodium/myo-inositol cotransporter), member } \\
3 \text {, essential for osteogenesis and bone formation, additive effects of } \\
\text { multiple genetic variants of SLC5A3 on the risk of coronary artery } \\
\text { disease }\end{array}$ & $63 \quad 64$ \\
\hline $\mathrm{CA} 12 \uparrow$ & See above & \\
\hline PHLDA1 $\uparrow$ & See above & \\
\hline FHL1 $\downarrow$ & $\begin{array}{l}\text { Four and a half LIM domains } 1 \text {, heavily expressed in skeletal and car- } \\
\text { diac muscles, plays a role in cardiovascular development, hypertrophy, } \\
\text { atherosclerosis, and angiogenesis }\end{array}$ & 6566 \\
\hline
\end{tabular}

Table 4.3: Identity and function of differentially expressed genes as identified by whole genome expression analysis. Donors were grouped based on their ability to differentiate into endothelial-like cells.

sion profile in their undifferentiated state. Therefore, many differentially expressed genes connected with endothelial cells might give the possibility to predict the po- 
tential of a given hMSC for endothelial differentiation. We consider that from genes involved in VEGF signaling the up-regulation of expression of EGR3 in proliferating hMSCs is of major importance. EGR3 is a transcription factor that plays a positive role in VEGFR1 transcription [40]. The abundance of EGR3 in hMSCs might make them more responsive to VEGF present in culture media and by that more prone to become EL-MSCs. Additionally EGR3 is a critical determinant of VEGF signaling in activated endothelial cells where the EGR3 expression level influences VEGF-mediated proliferation, migration, and tube formation [41]. It is possible that EGR3 plays a similar role in differentiating hMSCs. The observed down-regulation of two other genes involved in VEGF signaling that we found as differentially expressed in MSCs is probably connected to the fact that both CRYAB and IL7R are playing a role in VEGF signaling mostly in cases where cancer cells are involved [38, 42, 43].

Among genes that are specific to endothelial cells and were differentially expressed in proliferating hMSCs the expression of three was up-regulated (GFPT2, EGR3 and MEIS2) while one, IL7R, typical for microvascular cells, was down-regulated. Since GFPT2 47] and EGR3 are typical for all endothelial cells, MEIS2 is a marker of macrovascular endothelial cells and is not highly expressed in microvascular endothelial cells 49] and IL7R is present on microvascular endothelial cells 44] we suggest that hMSCs might be more susceptible to differentiate towards endothelial cells that are different in their characteristic from microvascular endothelial cells.

Our results do not allow us to draw firm conclusions about hMSC potential to differentiate towards endothelial cells based on the differentially expressed genes involved in cell survival, proliferation and migration or the one involved in cardiovascular system development and diseases. Further studies are necessary to conclude whether differences in these genes' expression are anyhow important for their application as therapeutic cells.

The applicability of hMSCs in regenerative medicine depends largely on their ability to expand in vitro without losing their potential to differentiate before reaching clinically relevant cell number. Since EL-MSCs are required in rather large quantities to be used in TE applications, we performed a series of experiments to check whether extended proliferation will influence multipotency of hMSCs. To compare our results with the ones previously obtained $[1,71$, we evaluated osteogenic and adipogenic differentiation along with endothelial differentiation on cells from all 10 passages. Our results concerning the osteogenic and adipogenic potential of serially passaged hMSCs were consistent with those obtained earlier. Interestingly, the endothelial differentiation was not influenced by a prolonged expansion phase, as showed both in the Matrigel assay as well as in the gene expression studies. In the Matrigel assay we observed that the parameters of structures formed after prolonged expansion are donor-dependent, therefore no conclusions about the influence of passage number can be made. According to our unpublished results we can conclude that in this assay it is rather the number of seeded cells that is crucial for the final outcome, therefore even cells from late passages that did not lose their ability to attach, spread and migrate could efficiently form CLSs. Cells from one investigated donor stopped proliferating 
at passage 6 which excluded them from the endothelial senescence study but in all other cases no negative effect of in vitro expansion on endothelial potential was observed. To our knowledge, this is the first observation of such phenomenon in hMSCs. From this study we conclude that hMSCs can be expanded in vitro at least up to passage 6 while keeping endothelial potential for effective use in tissue regeneration applications.

To summarize, our report provides several candidates for molecular markers that can be used for prediction of hMSC potential to differentiate into endothelial-like cells. We also showed that this potential is not affected by prolonged in vitro expansion as long as the cells keep proliferating. Altogether, our results indicate that hMSCs from various donors perform well enough to be considered in potential clinical applications. 


\subsection{Bibliography}

[1] R. Siddappa, R. Licht, C. van Blitterswijk, and J. de Boer. Donor variation and loss of multipotency during in vitro expansion of human mesenchymal stem cells for bone tissue engineering. J Orthop Res, 25(8):1029-41, 2007.

[2] C. M. Cowan, Y. Y. Shi, O. O. Aalami, Y. F. Chou, C. Mari, R. Thomas, N. Quarto, C. H. Contag, B. Wu, and M. T. Longaker. Adipose-derived adult stromal cells heal critical-size mouse calvarial defects. Nat Biotechnol, 22(5):560$7,2004$.

[3] R. O. Oreffo, A. Bennett, A. J. Carr, and J. T. Triffitt. Patients with primary osteoarthritis show no change with ageing in the number of osteogenic precursors. Scand J Rheumatol, 27(6):415-24, 1998.

[4] G. D'Ippolito, P. C. Schiller, C. Ricordi, B. A. Roos, and G. A. Howard. Agerelated osteogenic potential of mesenchymal stromal stem cells from human vertebral bone marrow. J Bone Miner Res, 14(7):1115-22, 1999.

[5] P. Bianco and P. Gehron Robey. Marrow stromal stem cells. J Clin Invest, 105(12):1663-8, 2000.

[6] M. F. Pittenger, A. M. Mackay, S. C. Beck, R. K. Jaiswal, R. Douglas, J. D. Mosca, M. A. Moorman, D. W. Simonetti, S. Craig, and D. R. Marshak. Multilineage potential of adult human mesenchymal stem cells. Science, 284(5411):143-7, 1999.

[7] M. Dezawa, H. Ishikawa, Y. Itokazu, T. Yoshihara, M. Hoshino, S. Takeda, C. Ide, and Y. Nabeshima. Bone marrow stromal cells generate muscle cells and repair muscle degeneration. Science, 309(5732):314-7, 2005.

[8] X. Jiang, H. Q. Cao, L. Y. Shi, S. Y. Ng, L. W. Stanton, and S. Y. Chew. Nanofiber topography and sustained biochemical signaling enhance human mesenchymal stem cell neural commitment. Acta Biomater, 2011.

[9] J. Sanchez-Ramos, S. Song, F. Cardozo-Pelaez, C. Hazzi, T. Stedeford, A. Willing, T. B. Freeman, S. Saporta, W. Janssen, N. Patel, D. R. Cooper, and P. R. Sanberg. Adult bone marrow stromal cells differentiate into neural cells in vitro. Exp Neurol, 164(2):247-56, 2000.

[10] K. Janeczek Portalska, A. Leferink, N. Groen, H. Fernandes, L. Moroni, C. van Blitterswijk, and J. de Boer. Endothelial differentiation of mesenchymal stromal cells. PLoS One, 7(10):e46842, 2012.

[11] J. Oswald, S. Boxberger, B. Jorgensen, S. Feldmann, G. Ehninger, M. Bornhauser, and C. Werner. Mesenchymal stem cells can be differentiated into endothelial cells in vitro. Stem Cells, 22(3):377-84, 2004. 
[12] J. W. Liu, S. Dunoyer-Geindre, V. Serre-Beinier, G. Mai, J. F. Lambert, R. J. Fish, G. Pernod, L. Buehler, H. Bounameaux, and E. K. Kruithof. Characterization of endothelial-like cells derived from human mesenchymal stem cells. $J$ Thromb Haemost, 5(4):826-34, 2007.

[13] J. Rouwkema, N. C. Rivron, N. M. S. Bettahalli, D. Stamatialis, M. Wessling, and C. A. van Blitterswijk. Mesenchymal stem cells differentiate towards endothelial cells in a prevascularized bone tissue engineering setting. Tissue Eng Part A, 01 2008.

[14] Y. Cao, Z. Sun, L. Liao, Y. Meng, Q. Han, and R. C. Zhao. Human adipose tissue-derived stem cells differentiate into endothelial cells in vitro and improve postnatal neovascularization in vivo. Biochem Biophys Res Commun, 332(2):3709, 2005.

[15] L. J. Fischer, S. McIlhenny, T. Tulenko, N. Golesorkhi, P. Zhang, R. Larson, J. Lombardi, I. Shapiro, and P. J. DiMuzio. Endothelial differentiation of adiposederived stem cells: effects of endothelial cell growth supplement and shear force. J Surg Res, 152(1):157-66, 2009.

[16] G. V. Silva, S. Litovsky, J. A. Assad, A. L. Sousa, B. J. Martin, D. Vela, S. C. Coulter, J. Lin, J. Ober, W. K. Vaughn, R. V. Branco, E. M. Oliveira, R. He, Y. J. Geng, J. T. Willerson, and E. C. Perin. Mesenchymal stem cells differentiate into an endothelial phenotype, enhance vascular density, and improve heart function in a canine chronic ischemia model. Circulation, 111(2):150-6, 2005.

[17] E. M. Fennema, A. J. Renard, A. Leusink, C. A. van Blitterswijk, and J. de Boer. The effect of bone marrow aspiration strategy on the yield and quality of human mesenchymal stem cells. Acta Orthop, 80(5):618-21, 2009.

[18] P. Horn, G. Bokermann, D. Cholewa, S. Bork, T. Walenda, C. Koch, W. Drescher, G. Hutschenreuther, M. Zenke, A. D. Ho, and W. Wagner. Impact of individual platelet lysates on isolation and growth of human mesenchymal stromal cells. Cytotherapy, 12(7):888-98, 2010.

[19] R. Siddappa, H. Fernandes, J. Liu, C. van Blitterswijk, and J. de Boer. The response of human mesenchymal stem cells to osteogenic signals and its impact on bone tissue engineering. Curr Stem Cell Res Ther, 2(3):209-20, 2007.

[20] D. G. Phinney, G. Kopen, W. Righter, S. Webster, N. Tremain, and D. J. Prockop. Donor variation in the growth properties and osteogenic potential of human marrow stromal cells. J Cell Biochem, 75(3):424-36, 1999.

[21] S. C. Mendes, J. M. Tibbe, M. Veenhof, K. Bakker, S. Both, P. P. Platenburg, F. C. Oner, J. D. de Bruijn, and C. A. van Blitterswijk. Bone tissue-engineered implants using human bone marrow stromal cells: effect of culture conditions and donor age. Tissue Eng, 8(6):911-20, 2002. 
[22] H. Alves, J. van Ginkel, N. Groen, M. Hulsman, A. Mentink, M. Reinders, C. van Blitterswijk, and J. de Boer. A mesenchymal stromal cell gene signature for donor age. PLoS One, 7(8):e42908, 2012.

[23] N. Quirici, D. Soligo, P. Bossolasco, F. Servida, C. Lumini, and G. L. Deliliers. Isolation of bone marrow mesenchymal stem cells by anti-nerve growth factor receptor antibodies. Exp Hematol, 30(7):783-91, 2002.

[24] B. O. Oyajobi, A. Lomri, M. Hott, and P. J. Marie. Isolation and characterization of human clonogenic osteoblast progenitors immunoselected from fetal bone marrow stroma using stro-1 monoclonal antibody. J Bone Miner Res, 14(3):351-61, 1999.

[25] F. Dell'Accio, C. De Bari, and F. P. Luyten. Molecular markers predictive of the capacity of expanded human articular chondrocytes to form stable cartilage in vivo. Arthritis Rheum, 44(7):1608-19, 2001.

[26] C. Fehrer and G. Lepperdinger. Mesenchymal stem cell aging. Exp Gerontol, 40(12):926-30, 2005.

[27] M. Kassem, L. Ankersen, E. F. Eriksen, B. F. Clark, and S. I. Rattan. Demonstration of cellular aging and senescence in serially passaged long-term cultures of human trabecular osteoblasts. Osteoporos Int, 7(6):514-24, 1997.

[28] M. Kveiborg, M. Kassem, B. Langdahl, E. F. Eriksen, B. F. Clark, and S. I. Rattan. Telomere shortening during aging of human osteoblasts in vitro and leukocytes in vivo: lack of excessive telomere loss in osteoporotic patients. Mech Ageing Dev, 106(3):261-71, 1999.

[29] W. Wagner, P. Horn, M. Castoldi, A. Diehlmann, S. Bork, R. Saffrich, V. Benes, J. Blake, S. Pfister, V. Eckstein, and A. D. Ho. Replicative senescence of mesenchymal stem cells: a continuous and organized process. PLoS One, 3(5):e2213, 2008.

[30] S. K. Both, A. J. van der Muijsenberg, C. A. van Blitterswijk, J. de Boer, and J. D. de Bruijn. A rapid and efficient method for expansion of human mesenchymal stem cells. Tissue Eng, 13(1):3-9, 2007.

[31] H. Fernandes, A. Mentink, R. Bank, R. Stoop, C. van Blitterswijk, and J. de Boer. Endogenous collagen influences differentiation of human multipotent mesenchymal stromal cells. Tissue Eng Part A, 16(5):1693-702, 2010.

[32] K. J. Livak and T. D. Schmittgen. Analysis of relative gene expression data using real-time quantitative pcr and the 2(-delta delta $\mathrm{c}(\mathrm{t}))$ method. Methods, 25(4):402-8, 2001.

[33] James M Wettenhall and Gordon K Smyth. limmagui: a graphical user interface for linear modeling of microarray data. Bioinformatics (Oxford, England), 20:3705-6, 2004. 
[34] M. Dominici, K. Le Blanc, I. Mueller, I. Slaper-Cortenbach, F. Marini, D. Krause, R. Deans, A. Keating, Dj Prockop, and E. Horwitz. Minimal criteria for defining multipotent mesenchymal stromal cells. the international society for cellular therapy position statement. Cytotherapy, 8(4):315-7, 2006.

[35] W. Xu, X. Zhang, H. Qian, W. Zhu, X. Sun, J. Hu, H. Zhou, and Y. Chen. Mesenchymal stem cells from adult human bone marrow differentiate into a cardiomyocyte phenotype in vitro. Exp Biol Med (Maywood), 229(7):623-31, 2004.

[36] F. Rastegar, D. Shenaq, J. Huang, W. Zhang, B. Q. Zhang, B. C. He, L. Chen, G. W. Zuo, Q. Luo, Q. Shi, E. R. Wagner, E. Huang, Y. Gao, J. L. Gao, S. H. Kim, J. Z. Zhou, Y. Bi, Y. Su, G. Zhu, J. Luo, X. Luo, J. Qin, R. R. Reid, H. H. Luu, R. C. Haydon, Z. L. Deng, and T. C. He. Mesenchymal stem cells: Molecular characteristics and clinical applications. World J Stem Cells, 2(4):67-80, 2010.

[37] P. Bianco, X. Cao, P. S. Frenette, J. J. Mao, P. G. Robey, P. J. Simmons, and C. Y. Wang. The meaning, the sense and the significance: translating the science of mesenchymal stem cells into medicine. Nat Med, 19(1):35-42, 2013.

[38] Q. Ruan, S. Han, W. G. Jiang, M. E. Boulton, Z. J. Chen, B. K. Law, and J. Cai. alphab-crystallin, an effector of unfolded protein response, confers antivegf resistance to breast cancer via maintenance of intracrine vegf in endothelial cells. Mol Cancer Res, 9(12):1632-43, 2011.

[39] J. Graw. Genetics of crystallins: cataract and beyond. Exp Eye Res, 88(2):173-89, 2009.

[40] E. Jin, J. Liu, J. Suehiro, L. Yuan, Y. Okada, V. Nikolova-Krstevski, K. Yano, L. Janes, D. Beeler, K. C. Spokes, D. Li, E. Regan, S. C. Shih, P. Oettgen, T. Minami, and W. C. Aird. Differential roles for ets, creb, and egr binding sites in mediating vegf receptor 1 expression in vivo. Blood, 114(27):5557-66, 2009.

[41] J. Suehiro, T. Hamakubo, T. Kodama, W. C. Aird, and T. Minami. Vascular endothelial growth factor activation of endothelial cells is mediated by early growth response-3. Blood, 115(12):2520-32, 2010.

[42] M. A. Al-Rawi, G. Watkins, R. E. Mansel, and W. G. Jiang. The effects of interleukin-7 on the lymphangiogenic properties of human endothelial cells. Int J Oncol, 27(3):721-30, 2005.

[43] J. Ming, Q. Zhang, X. Qiu, and E. Wang. Interleukin 7/interleukin 7 receptor induce c-fos/c-jun-dependent vascular endothelial growth factor-d up-regulation: a mechanism of lymphangiogenesis in lung cancer. Eur J Cancer, 45(5):866-73, 2009.

[44] D. Dus, A. Krawczenko, P. Zalecki, M. Paprocka, A. Wiedlocha, C. Goupille, and C. Kieda. Il-7 receptor is present on human microvascular endothelial cells. Immunol Lett, 86(2):163-8, 2003. 
[45] S. R. Pickens, N. D. Chamberlain, M. V. Volin, R. M. Pope, N. E. Talarico, 2nd Mandelin, A. M., and S. Shahrara. Characterization of interleukin-7 and interleukin-7 receptor in the pathogenesis of rheumatoid arthritis. Arthritis Rheum, 63(10):2884-93, 2011.

[46] J. Ming, G. Jiang, Q. Zhang, X. Qiu, and E. Wang. Interleukin-7 up-regulates cyclin d1 via activator protein-1 to promote proliferation of cell in lung cancer. Cancer Immunol Immunother, 61(1):79-88, 2012.

[47] G. Wu, T. E. Haynes, W. Yan, and C. J. Meininger. Presence of glutamine:fructose-6-phosphate amidotransferase for glucosamine-6-phosphate synthesis in endothelial cells: effects of hyperglycaemia and glutamine. Diabetologia, 44(2):196-202, 2001.

[48] A. G. Nerlich, U. Sauer, V. Kolm-Litty, E. Wagner, M. Koch, and E. D. Schleicher. Expression of glutamine:fructose-6-phosphate amidotransferase in human tissues: evidence for high variability and distinct regulation in diabetes. Diabetes, 47(2):170-8, 1998.

[49] P. Murthi, U. Hiden, G. Rajaraman, H. Liu, A. J. Borg, F. Coombes, G. Desoye, S. P. Brennecke, and B. Kalionis. Novel homeobox genes are differentially expressed in placental microvascular endothelial cells compared with macrovascular cells. Placenta, 29(7):624-30, 2008.

[50] M. A. Crowley, L. K. Conlin, E. H. Zackai, M. A. Deardorff, B. D. Thiel, and N. B. Spinner. Further evidence for the possible role of meis2 in the development of cleft palate and cardiac septum. Am J Med Genet A, 152A(5):1326-7, 2010.

[51] A. Khurana, P. Liu, P. Mellone, L. Lorenzon, B. Vincenzi, K. Datta, B. Yang, R. J. Linhardt, W. Lingle, J. Chien, A. Baldi, and V. Shridhar. Hsulf-1 modulates fgf2- and hypoxia-mediated migration and invasion of breast cancer cells. Cancer Res, 71(6):2152-61, 2011.

[52] C. H. Han, Y. J. Huang, K. H. Lu, Z. Liu, G. B. Mills, Q. Wei, and L. E. Wang. Polymorphisms in the sulf1 gene are associated with early age of onset and survival of ovarian cancer. J Exp Clin Cancer Res, 30:5, 2011.

[53] J. D. Yang, Z. Sun, C. Hu, J. Lai, R. Dove, I. Nakamura, J. S. Lee, S. S. Thorgeirsson, K. J. Kang, I. S. Chu, and L. R. Roberts. Sulfatase 1 and sulfatase 2 in hepatocellular carcinoma: associated signaling pathways, tumor phenotypes, and survival. Genes Chromosomes Cancer, 50(2):122-35, 2011.

[54] A. Lapucci, M. Lulli, A. Amedei, L. Papucci, E. Witort, F. Di Gesualdo, F. Bertolini, G. Brewer, A. Nicolin, A. Bevilacqua, N. Schiavone, D. Morello, M. Donnini, and S. Capaccioli. zeta-crystallin is a bcl-2 mrna binding protein involved in bcl-2 overexpression in t-cell acute lymphocytic leukemia. FASEB J, 24(6):1852-65, 2010. 
[55] C. Battke, E. Kremmer, J. Mysliwietz, G. Gondi, C. Dumitru, S. Brandau, S. Lang, D. Vullo, C. Supuran, and R. Zeidler. Generation and characterization of the first inhibitory antibody targeting tumour-associated carbonic anhydrase xii. Cancer Immunol Immunother, 60(5):649-58, 2011.

[56] M. J. Hsieh, K. S. Chen, H. L. Chiou, and Y. S. Hsieh. Carbonic anhydrase xii promotes invasion and migration ability of mda-mb-231 breast cancer cells through the p38 mapk signaling pathway. Eur J Cell Biol, 89(8):598-606, 2010.

[57] N. Oksala, M. Levula, M. Pelto-Huikko, L. Kytomaki, J. T. Soini, J. Salenius, M. Kahonen, P. J. Karhunen, R. Laaksonen, S. Parkkila, and T. Lehtimaki. Carbonic anhydrases ii and xii are up-regulated in osteoclast-like cells in advanced human atherosclerotic plaques-tampere vascular study. Ann Med, 42(5):360-70, 2010.

[58] J. D. Gottsch, G. D. Seitzman, E. H. Margulies, A. L. Bowers, A. J. Michels, S. Saha, A. S. Jun, W. J. Stark, and S. H. Liu. Gene expression in donor corneal endothelium. Arch Ophthalmol, 121(2):252-8, 2003.

[59] A. Sakthianandeswaren, M. Christie, C. D’Andreti, C. Tsui, R. N. Jorissen, S. Li, N. I. Fleming, P. Gibbs, L. Lipton, J. Malaterre, R. G. Ramsay, T. J. Phesse, M. Ernst, R. E. Jeffery, R. Poulsom, S. J. Leedham, S. Segditsas, I. P. Tomlinson, O. K. Bernhard, R. J. Simpson, F. Walker, M. C. Faux, N. Church, B. Catimel, D. J. Flanagan, E. Vincan, and O. M. Sieber. Phlda1 expression marks the putative epithelial stem cells and contributes to intestinal tumorigenesis. Cancer Res, 71(10):3709-19, 2011.

[60] G. S. Hossain, J. V. van Thienen, G. H. Werstuck, J. Zhou, S. K. Sood, J. G. Dickhout, A. B. de Koning, D. Tang, D. Wu, E. Falk, R. Poddar, D. W. Jacobsen, K. Zhang, R. J. Kaufman, and R. C. Austin. Tdag51 is induced by homocysteine, promotes detachment-mediated programmed cell death, and contributes to the cevelopment of atherosclerosis in hyperhomocysteinemia. J Biol Chem, 278(32):30317-27, 2003.

[61] M. E. Curran, D. L. Atkinson, A. K. Ewart, C. A. Morris, M. F. Leppert, and M. T. Keating. The elastin gene is disrupted by a translocation associated with supravalvular aortic stenosis. Cell, 73(1):159-68, 1993.

[62] P. S. Clifford, S. R. Ella, A. J. Stupica, Z. Nourian, M. Li, L. A. Martinez-Lemus, K. A. Dora, Y. Yang, M. J. Davis, U. Pohl, G. A. Meininger, and M. A. Hill. Spatial distribution and mechanical function of elastin in resistance arteries: a role in bearing longitudinal stress. Arterioscler Thromb Vasc Biol, 31(12):288996, 2011.

[63] Z. Dai, S. K. Chung, D. Miao, K. S. Lau, A. W. Chan, and A. W. Kung. Sodium/myo-inositol cotransporter 1 and myo-inositol are essential for osteogenesis and bone formation. J Bone Miner Res, 26(3):582-90, 2011. 
[64] S. Kathiresan, B. F. Voight, S. Purcell, K. Musunuru, D. Ardissino, P. M. Mannucci, S. Anand, J. C. Engert, N. J. Samani, H. Schunkert, J. Erdmann, M. P. Reilly, D. J. Rader, T. Morgan, J. A. Spertus, M. Stoll, D. Girelli, P. P. McKeown, C. C. Patterson, D. S. Siscovick, C. J. O’Donnell, R. Elosua, L. Peltonen, V. Salomaa, S. M. Schwartz, O. Melander, D. Altshuler, P. A. Merlini, C. Berzuini, L. Bernardinelli, F. Peyvandi, M. Tubaro, P. Celli, M. Ferrario, R. Fetiveau, N. Marziliano, G. Casari, M. Galli, F. Ribichini, M. Rossi, F. Bernardi, P. Zonzin, A. Piazza, J. Yee, Y. Friedlander, J. Marrugat, G. Lucas, I. Subirana, J. Sala, R. Ramos, J. B. Meigs, G. Williams, D. M. Nathan, C. A. MacRae, A. S. Havulinna, G. Berglund, J. N. Hirschhorn, R. Asselta, S. Duga, M. Spreafico, M. J. Daly, J. Nemesh, J. M. Korn, S. A. McCarroll, A. Surti, C. Guiducci, L. Gianniny, D. Mirel, M. Parkin, N. Burtt, S. B. Gabriel, J. R. Thompson, P. S. Braund, B. J. Wright, A. J. Balmforth, S. G. Ball, A. S. Hall, P. LinselNitschke, W. Lieb, A. Ziegler, I. Konig, C. Hengstenberg, M. Fischer, K. Stark, A. Grosshennig, M. Preuss, H. E. Wichmann, S. Schreiber, W. Ouwehand, P. Deloukas, M. Scholz, F. Cambien, M. Li, Z. Chen, R. Wilensky, W. Matthai, A. Qasim, H. H. Hakonarson, J. Devaney, M. S. Burnett, et al. Genome-wide association of early-onset myocardial infarction with single nucleotide polymorphisms and copy number variants. Nat Genet, 41(3):334-41, 2009.

[65] P. H. Chu and J. Chen. The novel roles of four and a half lim proteins 1 and 2 in the cardiovascular system. Chang Gung Med J, 34(2):127-34, 2011.

[66] G. Kwapiszewska, M. Wygrecka, L. M. Marsh, S. Schmitt, R. Trosser, J. Wilhelm, K. Helmus, B. Eul, A. Zakrzewicz, H. A. Ghofrani, R. T. Schermuly, R. M. Bohle, F. Grimminger, W. Seeger, O. Eickelberg, L. Fink, and N. Weissmann. Fhl-1, a new key protein in pulmonary hypertension. Circulation, 118(11):1183-94, 2008.

[67] G. Kasper, L. Mao, S. Geissler, A. Draycheva, J. Trippens, J. Kuhnisch, M. Tschirschmann, K. Kaspar, C. Perka, G. N. Duda, and J. Klose. Insights into mesenchymal stem cell aging: involvement of antioxidant defense and actin cytoskeleton. Stem Cells, 27(6):1288-97, 2009.

[68] R. Auerbach, R. Lewis, B. Shinners, L. Kubai, and N. Akhtar. Angiogenesis assays: a critical overview. Clin Chem, 49(1):32-40, 2003.

[69] David A. Ingram, Laura E. Mead, Hiromi Tanaka, Virginia Meade, Amy Fenoglio, Kelly Mortell, Karen Pollok, Michael J. Ferkowicz, David Gilley, and Mervin C. Yoder. Identification of a novel hierarchy of endothelial progenitor cells using human peripheral and umbilical cord blood. Blood, 104(9):2752-2760, 2004.

[70] S. Levenberg, J. S. Golub, M. Amit, J. Itskovitz-Eldor, and R. Langer. Endothelial cells derived from human embryonic stem cells. Proc Natl Acad Sci U S A, 99(7):4391-6, 2002.

[71] H. Alves, U. Munoz-Najar, J. De Wit, A. J. Renard, J. H. Hoeijmakers, J. M. Sedivy, C. Van Blitterswijk, and J. De Boer. A link between the accumulation 
of dna damage and loss of multi-potency of human mesenchymal stromal cells. J Cell Mol Med, 14(12):2729-38, 2010. 



\title{
Chapter 5
}

\section{Collagen modules for in situ delivery of mesenchymal stromal cell-derived endothelial cells for improved angiogenesis}

Karolina Janeczek Portalska, M. Dean Chamberlain, Chuen Lo, Clemens van Blitterswijk, Michael V. Sefton and Jan de Boer

\begin{abstract}
Modular tissue engineering is a strategy to create scalable, self-assembling, threedimensional tissue constructs. This strategy was used to deliver endothelial-like cells derived from bone marrow mesenchymal stromal cells (EL-MSCs) to locally induce vascularization. First, tissue engineered modules were formed, comprising EL-MSCs and collagen-based cylinders. Seven days of module culture in a microfluidic chamber under continuous flow resulted in the formation of interstices, formed by random packing of the modules, which served as channels and were lined by the EL-MSCs. We observed maintenance of the endothelial phenotype of the EL-MSCs as demonstrated by CD31 staining and the cells proliferated well. Next, collagen modules covered with EL-MSCs, with or without embedded MSCs, were implanted subcutaneously in immune-compromised SCID/Bg mice. After 7 days, CD31 positive vessels were observed in the samples. This data demonstrates the feasibility of EL-MSCs coated collagen module as a strategy to locally stimulate angiogenesis and vasculogenesis.
\end{abstract}

\subsection{Introduction}

There is a great need for technology to enhance the formation of blood vessels, such as in peripheral vascular disease (PVD) or tissue engineering of large three-dimensional 
tissues. As such, engineering of small diameter blood vessels is one of the major challenges in current tissue engineering and revascularization strategies. Numerous trials have been performed to discover the optimal way of restoring or introducing vascular networks in the tissues that require such treatment. Delivery of cells of endothelial nature in situ, either in the tissue engineered construct or in the human body, has been one of these strategies. There are various types of endothelial cells (EC) which are able to improve tissue vascularization, either by providing signals that induce angiogenesis [1] or by contributing to the new vessel system by self-organization into capillaries that then get connected to the surrounding vascular network [2]. The usage of those cells in therapy is unfortunately hampered due to problems with their isolation, expansion capacity and the lack of autologous sources [3 5]. As an alternative, we and others have investigated the possibility of using another cell type, i.e. mesenchymal stromal cells (MSCs), in therapies that require vessel regeneration. MSCs are adult cells that can easily be isolated from many sources including adipose tissue, tibia, femur, lumbar spine, and trabecular bone [6 9]. MSCs can be expanded in vitro and have the capacity to differentiate into the adipogenic, osteogenic and chondrogenic lineages [10] as well as towards endothelial cells, skeletal muscle cells and neural cells 11 13. The differentiation of MSCs is influenced by soluble factors 14], oxygen tension [15] and mechanical stimuli such as flow or sheer stress [16]. Another important feature of MSCs is that they secrete various growth factors and cytokines by which they can influence both cells within tissue engineered constructs as well as cells from surrounding host tissues. It was shown that by this trophic effect, MSCs can among others inhibit apoptosis, fibrosis and stimulate angiogenesis 17], which is beneficial for the survival of cells within the graft.

The first experiments in which MSCs were applied in vascular therapies were performed by simple injection of the cells into the vein [18. The assumption was that injected MSCs would reach the tissue where vascularization is needed through the regular blood flow. The observed improvement of vascularization was very limited, but was seen as proof of principle and it encouraged further research in this area. It was hypothesized, that simple injection of cells might not be the best way of delivering them at the place of injury. The potential of MSCs in vascular network formation could be improved by providing a matrix support that will direct these cells towards formation of capillaries being able to connect with the recipient's vascular network.

One of the approaches to create scalable, self-assembling, three-dimensional tissue constructs is modular tissue engineering. This technique allows fabricating tissue building blocks with specific features and then using these modular units to engineer biological tissues bottom up 19]. This is of crucial importance because the tissues to be engineered (e.g. fragments of bone) are often in the centimeter range and thus, too large to be generated in vitro in one piece. There are several ways to create modular blocks, including assembling of hydrogel layers [20], aggregation of microtissues 21], direct gel printing 22 and using cell sheets 23 . In order to build larger tissues, such blocks are then assembled by random packaging 24 26] or layer stacking [23]. Such systems can be used, among others, to improve vascular network formation within 
an engineered construct by providing channels that can serve as a route for both implanted cells and in-growing host vessels.

Cooper et al. showed that coating collagen modules with HUVECs prevented loss of shape of these modules and allowed for vessel in-growth in contrast to the situation when uncoated modules were implanted; the latter led to creation of an indistinguishable mass of collagen and limited vessel penetration 27]. Chamberlain et al. 28 showed that endothelial cell coated collagen constructs with embedded MSCs can be used for the formation of functional blood vessels. They used MSCs and ECs isolated from Sprague-Dawley rats (ECs from aorta and MSCs from bone marrow). To obtain clinically relevant data we decided to use human MSCs and ECs in the following experiments.

In our previous work 13, 29, we showed that human MSCs can be differentiated into endothelial-like cells (EL-MSCs), which can be used to create vascular networks within grafts. We showed that EL-MSCs express characteristic endothelial markers and perform well in in vitro functional tests like Ac-LDL uptake and capillary-like structure formation on Matrigel and will contribute to the vasculature upon implantation in immune-deficient mice. Importantly, MSCs used for obtaining EL-MSCs can be autologous to the patients. In our previous study [30] we have observed donor variability among MSCs obtained from various donors. All cells that we tested responded for applied differentiation protocol, showing endothelial phenotype but with varying efficiency. Therefore, to be able to compare obtained data with the one obtained previously or after, we decided to use the immortalized clone which we tested before also for this study.

We have also tested several ways of delivering those cells in vivo, employing either a gel (Matrigel) plug or a PLLA /PLGL scaffold [13]. In this manuscript, we will describe how EL-MSCs can be combined with collagen modules, in which a clinically approved biomaterial is used, is easy to obtain and is cheaper than Matrigel, but also can be formed in vitro, which would enable in vivo formation of channels lined with cells. We hypothesize, that EL-MSCs in modules are useful for the pre-formation of functional vasculature in tissue engineered constructs.

\subsection{Materials and methods}

\subsubsection{Isolation and culture}

An immortalized clone of human mesenchymal stromal cells (referred to as iMSCs, a kind gift of Prof. Ola Myklebost) was used in these studies. Cells were grown in MSC proliferation medium which contains minimal essential medium (alfa-MEM, GIBCO) supplemented with $10 \%$ fetal bovine serum (FBS, Lonza), $100 \mathrm{U} / \mathrm{ml}$ penicillin (GIBCO), $10 \mu \mathrm{g} / \mathrm{ml}$ streptomycin (GIBCO), $2 \mathrm{mM} \mathrm{L-glutamin} \mathrm{(GIBCO),} 0.2$ mM L-ascorbic acid 2-phosphate magnesium salt (ASAp, Sigma Aldrich) and 1ng/ml basic fibroblast growth factor (bFGF, Fisher Scientific) at $37^{\circ} \mathrm{C}$ in a humid atmo- 
sphere at $5 \% \mathrm{CO}_{2}$. Human umbilical vein endothelial cells (HUVEC, Lonza) were cultured in endothelial growth medium (EGM-2, Lonza).

\subsubsection{Endothelial induction of MSCs}

iMSCs at passage 25 were used for endothelial induction, as described previously [13]. Cells were seeded at a density of 3,000 cells per $\mathrm{cm}^{2}$ on tissue culture plastic in EGM-2 and cultured for 10 days. For induction on Matrigel, wells of 6 -well plates were coated with $1 \mathrm{ml}$ of growth factor reduced Matrigel (BD Bioscience) diluted 1:1 in EGM-2 without growth factors. Cells were seeded at a density of 30,000 cells per $\mathrm{cm}^{2}$ and cultured in a humid atmosphere with $5 \% \mathrm{CO}_{2}$ for 24 hours. Cells that were cultured according to this protocol will be referred to as EL-MSCs.

\subsubsection{Collagen module fabrication}

Modular collagen cylinders were fabricated as described before 25]. In brief, Purcol acidified collagen (type I, bovine dermal, $3 \mathrm{mg} / \mathrm{ml}$, Cedarlane) was mixed with 10x minimum essential medium (Invitrogen); $128 \mu \mathrm{l}$ of 10x medium per ml of collagen, and neutralized with $0.8 \mathrm{M} \mathrm{NaHCO}_{3}$ (Sigma-Aldrich). Pelleted iMSCs were mixed with the neutralized collagen $\left(1 \times 10^{6}\right.$ cells per $\left.\mathrm{ml}\right)$, and the solution was drawn into the lumen of an ethylene oxide gas-sterilized PE tube $(0.76 \mathrm{~mm}$ inner diameter x $1.22 \mathrm{~mm}$ outer diameter) connected to a syringe at one end. One hour incubation at $37^{\circ} \mathrm{C}$ was applied to allow collagen gelation. The gel-filled tubes were cut into fragments of 1.5 mm using a custom-built automated cutter (FCS Technology). Sections were vortexed gently in cell culture medium to recover the gel modules from the tubing lumen. The collagen-cell modules were allowed to settle, separated from the PE tubing, and cultured for 24 hours in Petri dishes under static conditions. Collagen-only modules were fabricated identically (same collagen concentration) without the addition of the cells.

\subsubsection{Cell-seeding}

HUVECs $\left(5 \times 10^{6}\right.$ cells per pack of modules; $1 \mathrm{ml}$ collagen $)$ or EL-MSCs $\left(2.5 \times 10^{6}\right.$ cells per pack of modules; $1 \mathrm{ml}$ collagen) were added to modules with or without encapsulated MSCs and incubated for 1 hour with gentle shaking. Modules were transferred into Petri dishes and cultured for another 24 hours. Four module systems were used for in vitro study: surface seeded EL-MSCs only, surface seeded EL-MSCs with embedded MSCs, surface seeded HUVECs with embedded MSCs and embedded MSCs only. The conditions "surface seeded EL-MSCs" and "surface seeded EL-MSCs with embedded MSCs" were also used for in vivo studies.

\subsubsection{Chamber assembly and flow circuit construction}

Modules were loaded in chambers (3D KUBE, Kiyatec) on $0.45 \mu \mathrm{m}$ polyethersulfone membranes (Figure 5.1A). These chambers were connected to a multichannel peristaltic pump and EGM-2 medium was circulated through the chamber in a closed 
loop as described before 31, 32]. Medium was pumped using a Masterflex L/S Digital standard drive with a 4-channel L/S multichannel pump head (Cole-Parmer, Vernon Hills, Il). $50 \mathrm{~mL}$ BD Falcon ${ }^{\mathrm{TM}}$ polystyrene conical tubes (Becton Dickinson) were used as a reservoir for cell culture medium and tubing was a combination of L/S 13 Tygonß lab tubing and L/S 13 Tygonß 2-stop tubing with connections made via luer lock connectors (Cole-Parmer). Flow dampeners (fabricated from Nalgene Cryogenic Vials) were used to reduce pulsation and remove air bubbles from the system (Figure $5.1 B-C$ ). $35 \mathrm{ml}$ of EGM-2 was circulated from separate reservoirs with a flow rate of $0.1 \mathrm{ml}$ per minute and was changed twice a week. Samples were maintained for 7 days at $37^{\circ} \mathrm{C}$ and $5 \% \mathrm{CO}_{2}$. After 7 days, remodeling chambers were perfused with $5 \%$ formalin for $30 \mathrm{~min}$. Chambers were opened, samples recovered and embedded in blocks of $5 \%$ agarose (Roche Diagnostics), and then fixed again in $10 \%$ formalin. Samples were embedded in paraffin and sectioned at $4 \mu \mathrm{m}$ (two level sections, $50 \mu \mathrm{m}$ apart) before analysis.

\subsubsection{Module implantation}

Male 6-week old Fox Chase severe combined immunodeficient / beige mice (SCID/Bg, Charles River) were anesthetized with a mixture of isofluorane and oxygen. Approximately 200 modules in $0.2 \mathrm{ml}$ PBS were injected subcutaneously, one injection per mouse. After implantation, mice were individually housed. One and three weeks after implantation mice were sacrificed and implants were recovered. Samples were fixed in $10 \%$ formalin, embedded in paraffin and sectioned at $4 \mu \mathrm{m}$ (two levels sections, $50 \mu \mathrm{m}$ apart) before staining. The study was approved by the University of Toronto Animal Care Committee.

\subsubsection{Histochemical analysis}

Hematoxylin (Sigma-Aldrich) and eosin (Sigma-Aldrich) staining as well as Masson's trichrome (Merck Chemicals) stainings were performed according to the manufacturers' protocols. Immunohistochemical analyses were used to detect and characterize the endothelium. Sheep anti-vWF (Dako), rabbit anti-CD31 (Santa Cruz Biotechnology), mouse anti-desmin (Dako) and rabbit anti-SMA (Vector Laboratories) antibodies were used. All primary antibodies recognize both mouse and human antigens. All secondary antibodies were obtained from Vector Laboratories. To detect endothelium of human origin, biotinylated Ulex europaeus agglutinin 1 (UEA-1) supplied by Vector Laboratories was used, after which anti-biotin secondary antibody (Vector Laboratories) was applied. All slides were developed with DAB Chromogen and weakly counterstained with Mayer's hematoxylin (Sigma-Aldrich). Normal mouse and human tissues served as positive controls. As described before [13, vessels were counted manually (without considering their size) based on Masson's trichrome staining by 3 observers blinded to the sample composition. Three areas of each sample (3 samples per condition) were used for this quantification. 

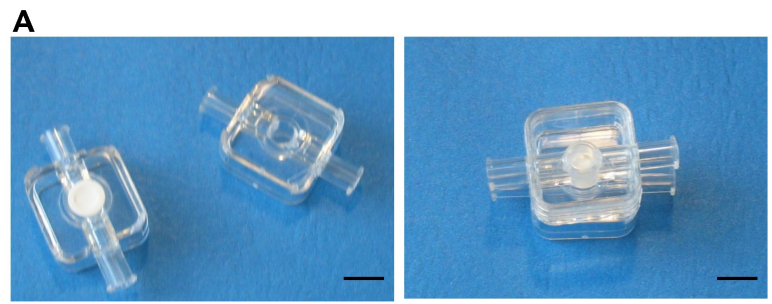

B

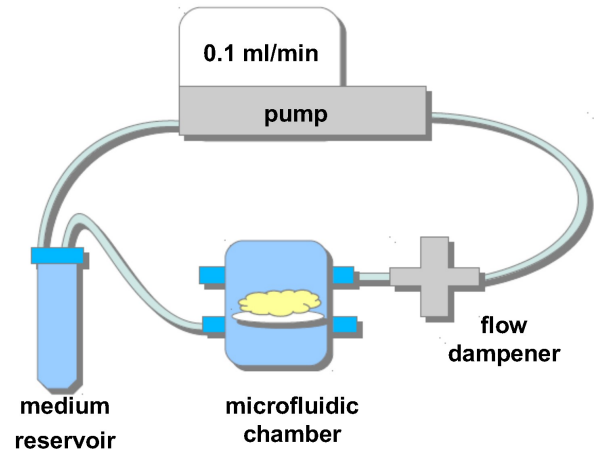

C

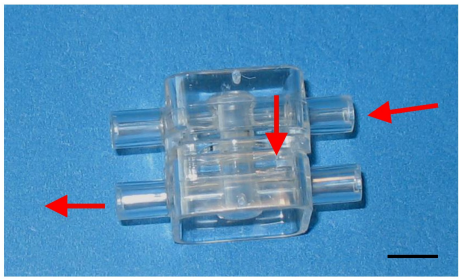

Figure 5.1: Experimental setup. Microfluidic chamber before and after assembly (A). Flow circuit (B). Scheme of medium flow through the chamber (C). Scale bar $1 \mathrm{~cm}$.

\subsubsection{Statistics}

Each experiment was performed in triplicate. Data that required multiple comparison test was analyzed in SPSS (PASW statistics) using one-way Anova followed by Tukey's multiple comparison test $(\mathrm{P}<0.05)$.

\section{$5.3 \quad$ Results}

\subsubsection{Collagen module assembly}

To examine EL-MSC behavior under flow conditions and relate those observations to our previous results [13], four types of modular constructs were assembled. We used collagen modules with surface seeded EL-MSCs only, surface seeded EL-MSCs with 
embedded MSCs, surface seeded HUVECs with embedded MSCs and embedded MSCs alone. The last two conditions were nearly the same as those used by Khan et al. 32 with, in our case, human instead of rat cells and were used as positive control for the system. The first two conditions were chosen to show EL-MSC potential in replacing endothelial cells. Collagen module preparation (Figure 5.2A) and the efficiency of coating with cells was assessed $24 \mathrm{~h}$ after cell seeding. As expected, MSCs within the modules were uniformly distributed (Figure $5.2 \mathrm{~B}$ ). The size of collagen modules with or without embedded MSCs was similar, with a diameter of around $0.7 \mathrm{~mm}$ and a length of $1.5 \mathrm{~mm}$ (estimation based on microscopic observations). Coating with HUVECs resulted in an approximately two-fold shrinkage of the modules (Figure $5.2 \mathrm{C}$ ), whereas coating with EL-MSCs induced even more shrinkage, both with empty and MSC-embedded modules, with a four-fold size reduction (Figure 5.2 C-D). Twenty four hours after cell seeding all modules were uniformly coated with cells.
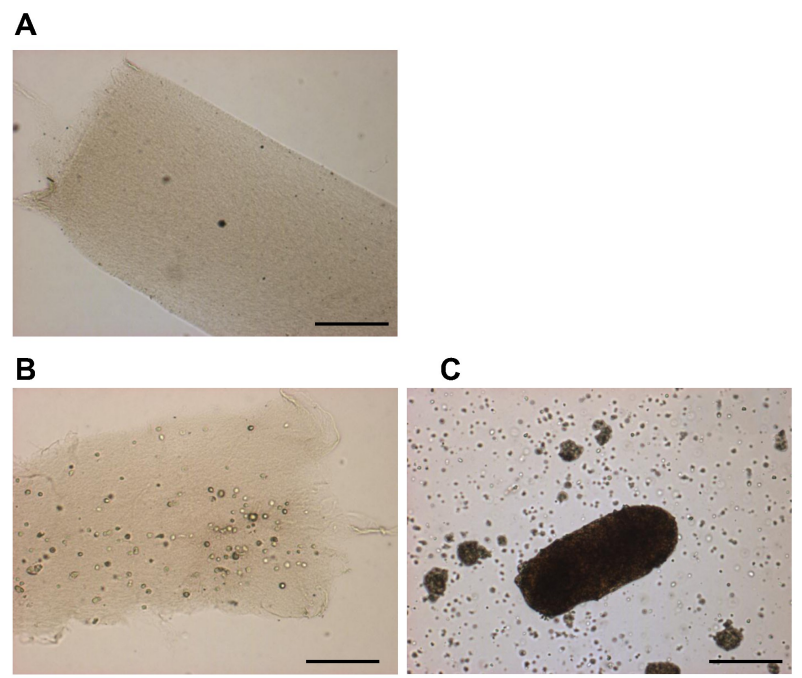

D

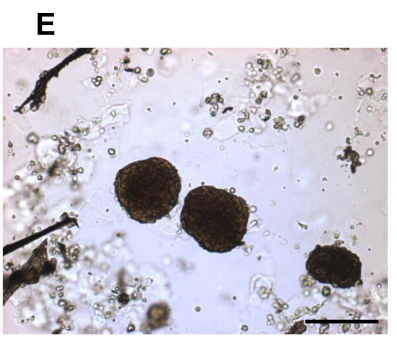

Figure 5.2: Collagen modules 24 hours after assembly: empty collagen modules (A), modules with embedded MSCs (B), modules with embedded MSCs and surface-seeded HUVECs (C), modules with surface-seeded EL-MSCs (D), modules with embedded MSCs and surface-seeded EL-MSCs (E). Scale bar $500 \mu \mathrm{m}$. 


\subsubsection{Cell characterization in microfluidic chamber}

Cell survival under flow conditions was assessed after 7 days. Collagen modules with embedded MSCs formed a single mass of collagen over that time period (Figure 5.3A). MSCs could be easily observed within the mass, however we did not witness evidence of proliferation (only single cells were observed with lack of cell colonies within the collagen). Similarly, MSC proliferation was also not identified in modules with embedded MSCs coated additionally with HUVECs (Figure 5.3 B). As shown before for rat endothelial cells 32], the endothelial coating of the collagen modules was still intact after 7 days of culture of HUVECs, but also here no increase in the amount of cells was observed. In contrast, we observed a large increase in the amount of EL-MSCs on the surface, but not in the interior of the modules (Figure 5.3 C-D). Several markers were examined to characterize the phenotype of MSCs and EL-MSCs under flow conditions. First, we stained the modules for the endothelial marker, CD31. No staining was observed in samples with embedded MSCs only (Figure 5.4 A), whereas staining was observed in the HUVEC-coated samples (Figure $5.4 \mathrm{~B}$ ). In samples with EL-MSC coating (Figure $5.4 \mathrm{C}-\mathrm{D}$ ), the cells present in the inter-modular region were CD31 positive, which indicates that EL-MSCs kept their phenotype acquired after Matrigel induction 13]. UEA-1 positive cells were found uniformly distributed throughout the whole sample only in constructs containing HUVECs (Figure 5.4F). In samples with EL-MSC coating but without embedded MSCs, several regions were found, in which cells were UEA-1 positive, but those regions were not uniformly spread through the sample (Figure 5.4 G). No UEA-1 positive cells were observed in modules with embedded MSCs, both in case of modules without coating as well as modules with EL-MSC coating (Figure $5.4 \mathrm{E}$ and $\mathrm{H}$ ).

To observe whether differentiation towards smooth muscle cells occurred in the system as described before 32], we performed smooth muscle actin (SMA) and desmin staining as smooth muscle cell and pericyte markers respectively (Figure 5.5), however no staining was observed. Therefore we can conclude that culture in EGM-2 supported endothelial phenotype of EL-MSCs, whereas did not induce MSC or ELMSC differentiation towards a smooth muscle phenotype.

\subsubsection{In situ delivery of endothelial cells}

To evaluate whether the collagen module system can be used to deliver EL-MSCs in the place of interest and whether a vascular network will be created at the place of administration, one package of modules was injected subcutaneously per immunocompromised SCID/Bg mouse. We implanted collagen modules coated with EL-MSCs with or without embedded MSCs. Embedded MSCs were included in this experiment, since these cells were required to support HMECs in the Butler et al. study 33. Samples were explanted at 7 and 21 days after implantation. Both after 7 and 21 days, we observed that the collagen mass was separated by layers of cells (Figure 5.6A and B) and the collagen modules were uniformly infiltrated by host blood vessels. Quantification based on Masson's trichrome staining (Figure 5.6 AC) showed that 7 days after injection, modules with and without embedded MSCs were penetrated by simi- 
A

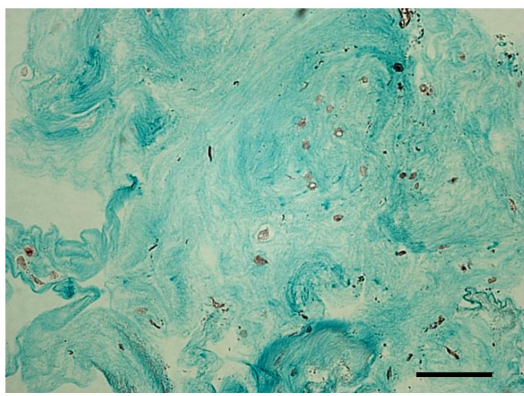

C

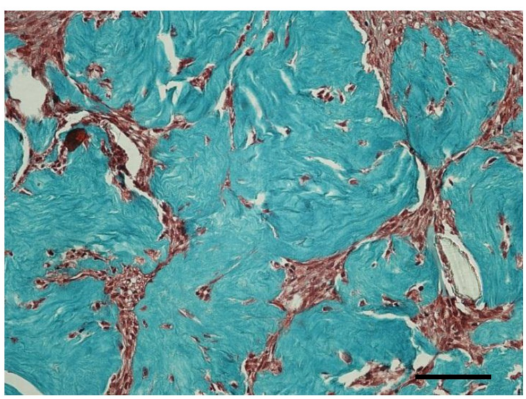

B

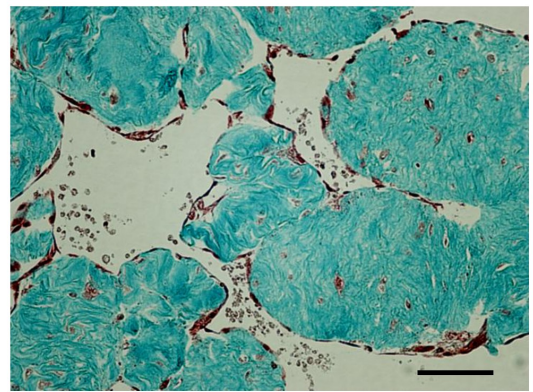

D

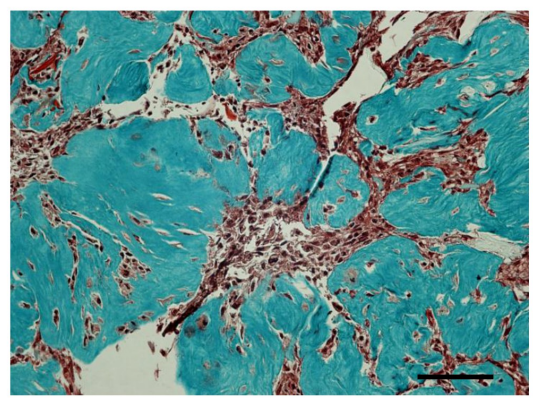

Figure 5.3: Cell migration and proliferation over time. Masson's trichrome staining was performed on samples subjected to flow conditions for 7 days. Collagen appeared blue while nuclei appeared dark brown. Modules with embedded MSCs (A), modules with embedded MSCs and surface-seeded HUVECs (B), modules with surface-seeded EL-MSCs (C), modules with embedded MSCs and surface-seeded EL-MSCs (D). In samples with embedded MSCs, flow did not cause a migration of cells from the interior of the modules towards the outer surfaces and the intermodular regions. EL-MSC coated modules showed a greater number of cells in the intermodular regions and a higher number of total cells, as compared to uncoated modules and modules coated with HUVECs. Scale bar $100 \mu \mathrm{m}$.

lar amounts of vessels. Results were different when the quantification was performed on samples explanted 21 days after injection. In case of collagen modules coated with EL-MSCs without embedded MSCs, the number of vessels was the same as at day 7, but in samples with embedded MSCs, a significant, two-fold decrease in vessel number was observed.

To confirm our results and further study the maturity of in-growing vessels, we performed several additional stainings including markers like CD31, UEA-1, SMA and desmin (Figure 5.7). Our results showed that the vessels were CD31 and SMA positive, which indicates mature blood vessels with a smooth muscle cell layer. Surprisingly, 

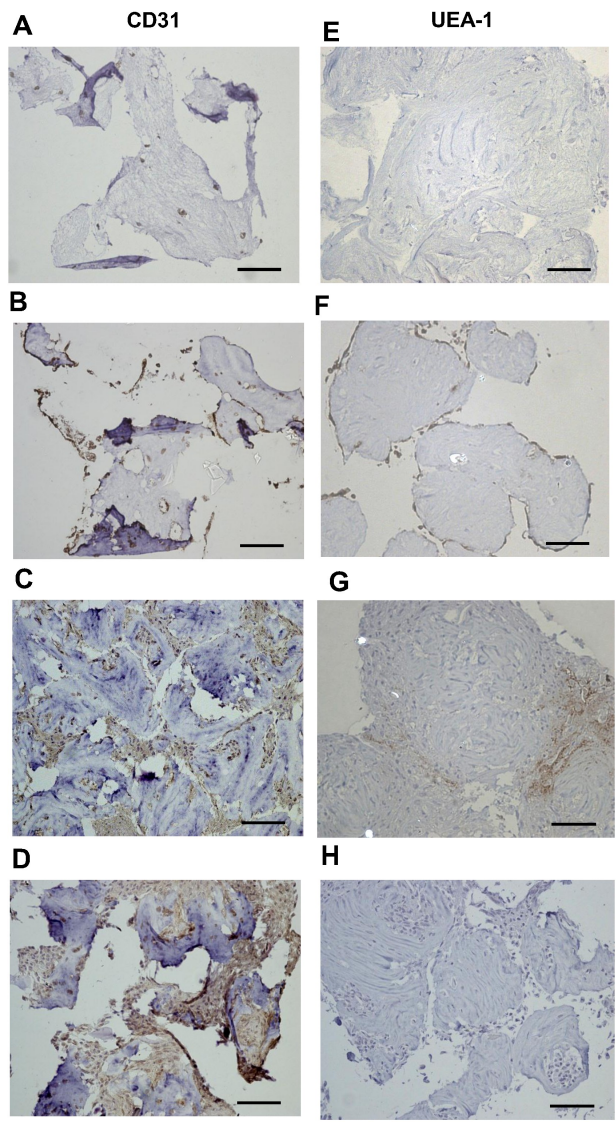

Figure 5.4: CD31 and UEA-1 staining. Staining was performed on samples subjected to flow conditions for 7 days. Cells were stained for CD31 (brown) and nuclei appeared blue. Modules with embedded MSCs (A), modules with embedded MSCs and surface-seeded HUVECs (B), modules with surface-seeded EL-MSCs (C), modules with embedded MSCs and surfaceseeded EL-MSCs (D). MSCs did not stain positive for CD31. In samples containing HUVECs or EL-MSCs, CD31 positive cells can be observed. Cells were stained for UEA-1 (brown) and nuclei appeared blue. Modules with embedded MSCs (E), modules with embedded MSCs and surface-seeded HUVECs (F), modules with surface-seeded EL-MSCs (G), modules with embedded MSCs and surface-seeded EL-MSCs (H). MSCs did not stain positive for UEA-1. In samples containing HUVECs or EL-MSCs without embedded MSCs, UEA-1 positive cells can be observed. Scale bar $100 \mu \mathrm{m}$.

we did not observe desmin-positive cells in the samples. The vessels present in the samples were also UEA-1 negative. 
A
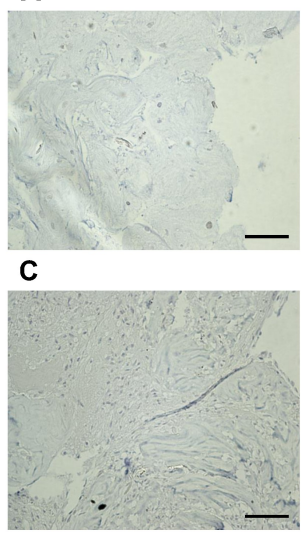

E

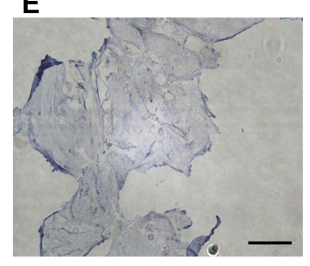

G

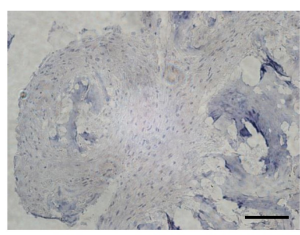

B

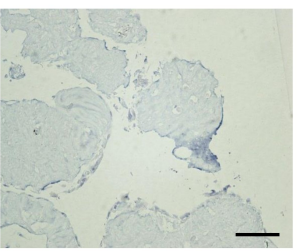

D

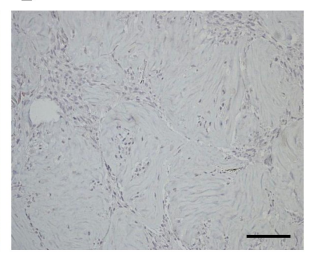

$\mathbf{F}$

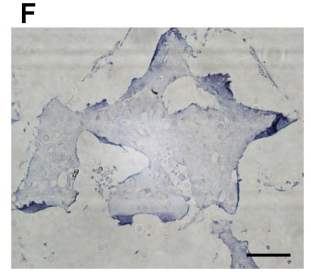

H

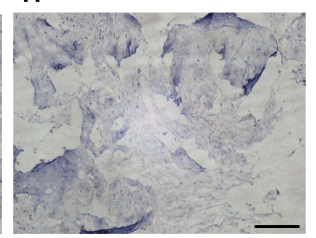

Figure 5.5: SMA and desmin staining. Staining was performed on samples subjected to flow conditions for 7 days. No SMA staining (brown) was observed in any modules, indicating the lack of cells that differentiated towards smooth muscle cells. Modules with embedded MSCs (A), modules with embedded MSCs and surface-seeded HUVECs (B), modules with surface-seeded ELMSCs (C), modules with embedded MSCs and surface-seeded EL-MSCs (D). Similarly to the SMA staining, no desmin staining (brown) was observed in any modules, indicating the lack of cells that differentiated towards smooth muscle cells. Modules with embedded MSCs (E), modules with embedded MSCs and surface-seeded HUVECs (F), modules with surface-seeded EL-MSCs (G), modules with embedded MSCs and surface-seeded EL-MSCs (H). Scale bar $100 \mu \mathrm{m}$.

\subsection{Discussion}

Modular tissue engineering allows for the formation of three-dimensional tissue constructs that can be scalable and have self-assembly abilities. Such systems can be used 

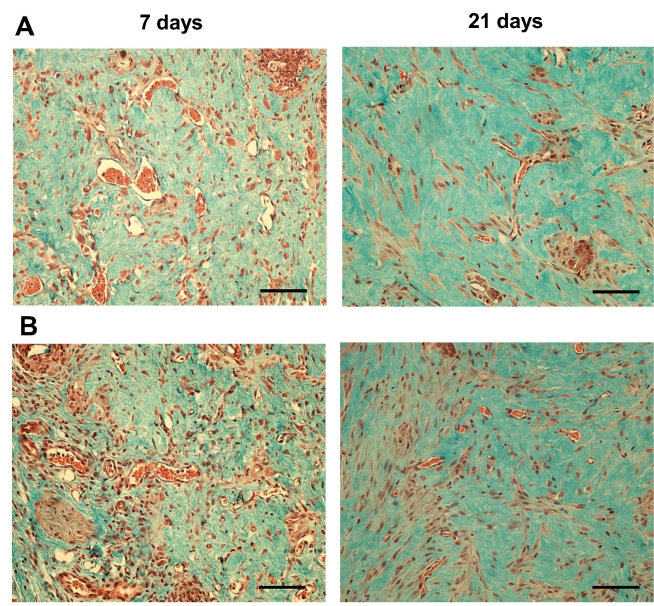

C

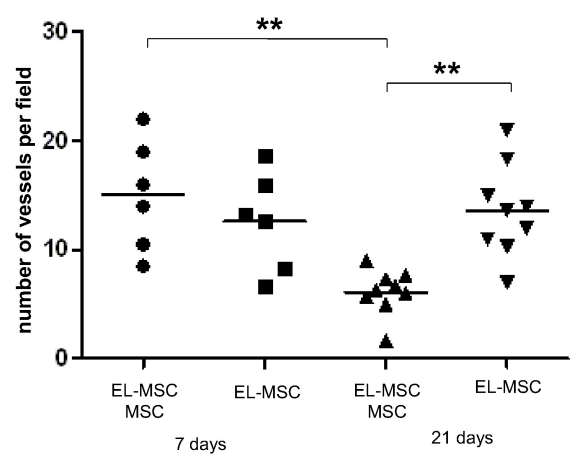

Figure 5.6: Blood vessel formation in vivo. Masson's trichrome staining of modules with embedded MSCs and surface-seeded EL-MSCs (A) and modules with surface-seeded EL-MSCs (B) after 7 and 21 days in vivo. Collagen appeared blue, erythrocytes are bright red and nuclei appeared brown. Presence of erythrocytes indicated that vessels that within the sample are functional. Scale bar $100 \mu \mathrm{m}$. Quantitative analysis of vessels in polymeric constructs (C). Seven days after injection, modules with and without embedded MSCs were penetrated by similar amounts of vessels. Twenty one days after injection, the number of vessels within samples coated with EL-MSCs without embedded MSCs was the same as at day 7, but in samples with embedded MSCs, a significant, two-fold decrease in vessel number was observed. Number of vessels per sample was quantified by three people blinded for the conditions. ${ }^{* *}$ denotes statistical significance $(\mathrm{P}<0.01)$.

among others to improve vascularization of implanted tissues by providing a route for host vessel in-growth 25]. It can also be implemented as a system to guide angiogenesis in the host ischemic tissues by the supply of cells that will secrete pro-angiogenic factors. 

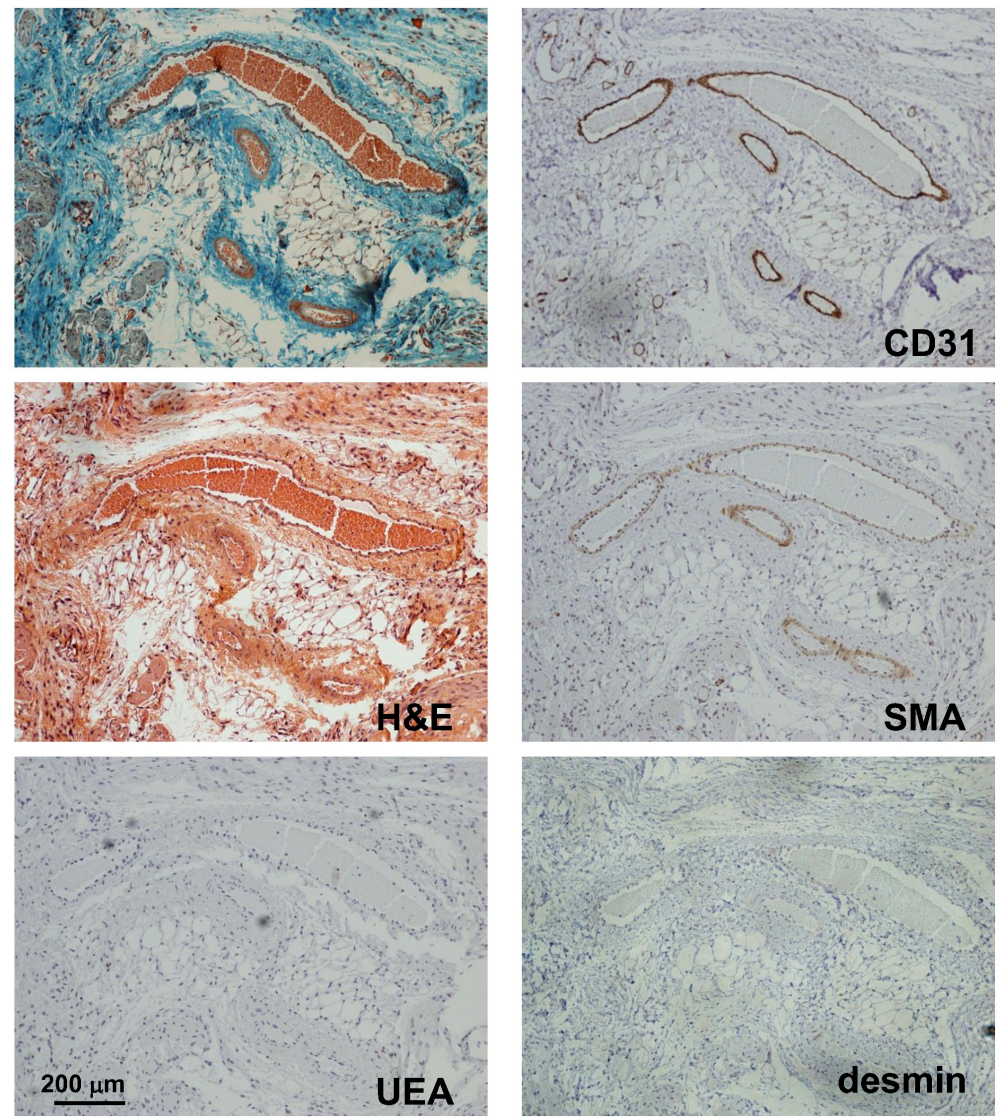

Figure 5.7: Immunohistochemistry on blood vessels. Modules with surface-seeded EL-MSCs were recovered after 21 days of in vivo culture and following stainings were performed: Masson's trichrome, H\&E, CD31, SMA, desmin and UEA-1. Observed vessels were CD31 and SMA positive, which indicates mature blood vessels with a smooth muscle cell layer. Scale bar 200 $\mu \mathrm{m}$.

Several in vitro and in vivo studies have shown the potential of the modular tissue engineering concept in enhancing modular construct remodeling upon implantation 27, 33, 34, which enables faster tissue and vessel in-growth. In this paper we describe modular tissue constructs with various cell types that were assembled and subjected to flow for 7 days to observe cell self-organization with the focus on the performance of EL-MSCs. We examined whether these cells can be used in prevascularization strategies. Additionally, the aspect of de-differentiation of EL-MSCs was analyzed. As observed previously, cell coating influences the size of collagen modules, possibly by traction forces, and this effect is dependent on the cell type 32, 35. 
Interestingly, covering the modules with EL-MSCs caused higher shrinkage than HUVEC coating which is most likely due to the faster spreading of EL-MSCs on the surface of the modules. Faster spreading resulted in an increased area subjected to the forces influencing the contraction of the modules [36]. Cells embedded within the modules did not cause any change in the module volume, as the 24 hours period was too short a time for the embedded MSCs to conduct significant matrix remodeling.

After 7 days of culture in the microfluidic chamber the effect of flow on cell behavior and phenotype was assessed. First of all, contrary to previous study with MSCs isolated from rat bone marrow 32], flow did not noticeably affect the differentiation of the embedded MSCs. We did not observe MSC migration towards the surface of modules, or differentiation towards SMCs or endothelial cells. This was unexpected considering the fact that many previous reports showed that growth factors and cytokines present in the medium together with applied mechanical forces can stimulate MSC differentiation 16, 37. A possible explanation is that in our system, MSCs were not directly exposed to shear forces. Also, the flow rate was lower than previously tested by Khan et al 32. Another observed difference was the absence of MSC migration from the interior of individual modules towards the perimeter, and lack of SMA expression, indicating that MSCs did not differentiate towards a smooth muscle cell phenotype. MSCs embedded in the modules also did not show any expression of endothelial-specific markers. These results confirm our previous findings, where Matrigel stimulation was necessary for induction of endothelial differentiation of MSCs 13 .

EL-MSCs which were subjected to flow conditions for 7 days increased in number both in the samples with and without embedded MSCs. This was not observed with HUVEC coated modules or in the study of Khan et al 32 that used rat aortic endothelial cells. It remains to be assessed whether this is due to the difference in the type of cells used, the differentiation protocol to which the EL-MSCs have been exposed or whether the immortalized nature of the EL-MSCs plays a role. Proliferating EL-MSCs were expressing the endothelial marker CD31, which indicates that even 7 days after Matrigel induction, these cells maintained their endothelial phenotype. This clearly shows that no dedifferentiation occurs in the tested conditions and we speculate that EL-MSCs, upon implantation in vivo, are able to maintain their endothelial phenotype in these conditions as well. Since one of the current challenges in applying MSCs in various therapies is to lock them in the desired differentiation stage [38], our study provides a good example of a differentiation protocol that allows for obtaining a stable phenotype of MSCs. The lack of SMA and desmin expression indicates that EL-MSCs did not differentiate into pericytes.

Remodeling is a critical and still not fully understood parameter determining the fate of tissue engineered constructs in vivo. Generally, implanted constructs are spontaneously invaded by host vasculature as a response to hypoxia signals released by the cells within the construct [39]. This process, when occurring spontaneously, is too slow to provide a proper level of oxygen and nutrients to allow cell survival in large grafts. In addition, for some patients, spontaneous vascularization will not be 
progressing well due to the patient's age or other factors compromising normal angiogenesis such as PVD [40]. Our in vitro results indicate that collagen modules covered with EL-MSCs can be valuable for various therapeutic applications. As shown in this in vitro study, EL-MSCs can proliferate on the surface of collagen modules. Increased number of cells in the place of implantation, which is hypoxic, will result in increased signals that are pro-angiogenic and, therefore, attract more vessel in-growth. We also tested whether the presence of embedded MSCs is beneficial for the EL-MSCs performance. We used Masson's trichrome staining for this purpose, since this method has been considered as the best for visualizing functional vessels connected with host vasculature network(presence of erythrocytes). The addition of MSCs did not influence the number of vessels within the sample 7 days after implantation. The situation changed after 21 days, where significantly fewer vessels within the sample were observed. We hypothesize that this phenomenon is related to the normal healing process enhanced by the modulatory effect on the immune-system by MSCs [41. Inflammation caused by the presence of the engineered construct and by the injection itself can have pro-angiogenic effects, because proteases released by recruited inflammatory cells can release reactive ECM-fragments and also activate ECM-bound pro-angiogenic growth factors 42 . Since bone marrow-derived MSCs can limit the inflammation, their presence in the construct can result in decreased density of vessels. This hypothesis can be supported by the reduced number of interstitial cells within construct with embedded MSCs. Such situation is typical for the tissue healing where vessel regression to the normal level is caused by apoptosis of endothelial and fibroblast cells. However, this assumption needs to be further investigated.

In conclusion, this paper presents an effective way of EL-MSC delivery in vivo which can be used to improve tissue vascularization. The method is simple and can be used for several applications including tissue engineered scaffold vascularization and PVD treatment. 


\subsection{Bibliography}

[1] Anne Marie Byrne, D. J. Bouchier-Hayes, and J. H. Harmey. Angiogenic and cell survival functions of vascular endothelial growth factor (vegf). Journal of Cellular and Molecular Medicine, 9(4):777-794, 2005.

[2] J. Rouwkema, J. de Boer, and C. A. Van Blitterswijk. Endothelial cells assemble into a 3-dimensional prevascular network in a bone tissue engineering construct. Tissue Eng, 12(9):2685-93, 2006.

[3] A. Tiwari, H. J. Salacinski, G. Hamilton, and A. M. Seifalian. Tissue engineering of vascular bypass grafts: role of endothelial cell extraction. Eur J Vasc Endovasc Surg, 21(3):193-201, 2001.

[4] R. N. Salomon, C. C. Hughes, F. J. Schoen, D. D. Payne, J. S. Pober, and P. Libby. Human coronary transplantation-associated arteriosclerosis. evidence for a chronic immune reaction to activated graft endothelial cells. Am J Pathol, 138(4):791-8, 1991.

[5] R. M. Nerem and D. Seliktar. Vascular tissue engineering. Annu Rev Biomed Eng, 3:225-43, 2001.

[6] R. Siddappa, R. Licht, C. van Blitterswijk, and J. de Boer. Donor variation and loss of multipotency during in vitro expansion of human mesenchymal stem cells for bone tissue engineering. J Orthop Res, 25(8):1029-41, 2007.

[7] C. M. Cowan, Y. Y. Shi, O. O. Aalami, Y. F. Chou, C. Mari, R. Thomas, N. Quarto, C. H. Contag, B. Wu, and M. T. Longaker. Adipose-derived adult stromal cells heal critical-size mouse calvarial defects. Nat Biotechnol, 22(5):560$7,2004$.

[8] R. O. Oreffo, A. Bennett, A. J. Carr, and J. T. Triffitt. Patients with primary osteoarthritis show no change with ageing in the number of osteogenic precursors. Scand J Rheumatol, 27(6):415-24, 1998.

[9] G. D'Ippolito, P. C. Schiller, C. Ricordi, B. A. Roos, and G. A. Howard. Agerelated osteogenic potential of mesenchymal stromal stem cells from human vertebral bone marrow. J Bone Miner Res, 14(7):1115-22, 1999.

[10] P. Bianco and P. Gehron Robey. Marrow stromal stem cells. J Clin Invest, 105(12):1663-8, 2000.

[11] M. Dezawa, H. Ishikawa, Y. Itokazu, T. Yoshihara, M. Hoshino, S. Takeda, C. Ide, and Y. Nabeshima. Bone marrow stromal cells generate muscle cells and repair muscle degeneration. Science, 309(5732):314-7, 2005.

[12] X. Jiang, H. Q. Cao, L. Y. Shi, S. Y. Ng, L. W. Stanton, and S. Y. Chew. Nanofiber topography and sustained biochemical signaling enhance human mesenchymal stem cell neural commitment. Acta Biomater, 2011. 
[13] K. Janeczek Portalska, A. Leferink, N. Groen, H. Fernandes, L. Moroni, C. van Blitterswijk, and J. de Boer. Endothelial differentiation of mesenchymal stromal cells. PLoS One, 7(10):e46842, 2012.

[14] M. F. Pittenger, A. M. Mackay, S. C. Beck, R. K. Jaiswal, R. Douglas, J. D. Mosca, M. A. Moorman, D. W. Simonetti, S. Craig, and D. R. Marshak. Multilineage potential of adult human mesenchymal stem cells. Science, 284(5411):143-7, 1999.

[15] D. P. Lennon, J. M. Edmison, and A. I. Caplan. Cultivation of rat marrowderived mesenchymal stem cells in reduced oxygen tension: effects on in vitro and in vivo osteochondrogenesis. J Cell Physiol, 187(3):345-55, 2001.

[16] E. D. O'Cearbhaill, M. A. Punchard, M. Murphy, F. P. Barry, P. E. McHugh, and V. Barron. Response of mesenchymal stem cells to the biomechanical environment of the endothelium on a flexible tubular silicone substrate. Biomaterials, 29(11):1610-9, 2008.

[17] A. I. Caplan and J. E. Dennis. Mesenchymal stem cells as trophic mediators. $J$ Cell Biochem, 98(5):1076-84, 2006.

[18] H. Kamihata, H. Matsubara, T. Nishiue, S. Fujiyama, Y. Tsutsumi, R. Ozono, H. Masaki, Y. Mori, O. Iba, E. Tateishi, A. Kosaki, S. Shintani, T. Murohara, T. Imaizumi, and T. Iwasaka. Implantation of bone marrow mononuclear cells into ischemic myocardium enhances collateral perfusion and regional function via side supply of angioblasts, angiogenic ligands, and cytokines. Circulation, 104(9):1046-52, 2001.

[19] J. W. Nichol and A. Khademhosseini. Modular tissue engineering: Engineering biological tissues from the bottom up. Soft Matter, 5(7):1312-1319, 2009.

[20] J. Yeh, Y. Ling, J. M. Karp, J. Gantz, A. Chandawarkar, G. Eng, 3rd Blumling, J., R. Langer, and A. Khademhosseini. Micromolding of shape-controlled, harvestable cell-laden hydrogels. Biomaterials, 27(31):5391-8, 2006.

[21] D. M. Dean, A. P. Napolitano, J. Youssef, and J. R. Morgan. Rods, tori, and honeycombs: the directed self-assembly of microtissues with prescribed microscale geometries. FASEB J, 21(14):4005-12, 2007.

[22] V. Mironov, T. Boland, T. Trusk, G. Forgacs, and R. R. Markwald. Organ printing: computer-aided jet-based 3d tissue engineering. Trends Biotechnol, 21(4):157-61, 2003.

[23] N. L'Heureux, S. Paquet, R. Labbe, L. Germain, and F. A. Auger. A completely biological tissue-engineered human blood vessel. FASEB J, 12(1):47-56, 1998.

[24] A. P. McGuigan, B. Leung, and M. V. Sefton. Fabrication of cell-containing gel modules to assemble modular tissue-engineered constructs [corrected]. Nat Protoc, 1(6):2963-9, 2006. 
[25] A. P. McGuigan and M. V. Sefton. Vascularized organoid engineered by modular assembly enables blood perfusion. Proc Natl Acad Sci U S A, 103(31):11461-6, 2006.

[26] A. P. McGuigan and M. V. Sefton. Design and fabrication of sub-mm-sized modules containing encapsulated cells for modular tissue engineering. Tissue Eng, 13(5):1069-78, 2007.

[27] T. P. Cooper and M. V. Sefton. Fibronectin coating of collagen modules increases in vivo huvec survival and vessel formation in scid mice. Acta Biomater, $7(3): 1072-83,2011$.

[28] M. D. Chamberlain, R. Gupta, and M. V. Sefton. Bone marrow-derived mesenchymal stromal cells enhance chimeric vessel development driven by endothelial cell-coated microtissues. Tissue Eng Part A, 18(3-4):285-94, 2012.

[29] J. Rouwkema, N. C. Rivron, N. M. S. Bettahalli, D. Stamatialis, M. Wessling, and C. A. van Blitterswijk. Mesenchymal stem cells differentiate towards endothelial cells in a prevascularized bone tissue engineering setting. Tissue Eng Part A, 01 2008.

[30] K. Janeczek Portalska, N. Groen, G. Krenning, N. Georgi, A. Mentink, M. C. Harmsen, C. van Blitterswijk, and J. de Boer. The effect of donor variation and senescence on endothelial differentiation of human mesenchymal stromal cells. Tissue Eng Part A, 2013.

[31] O. F. Khan and M. V. Sefton. Endothelial cell behaviour within a microfluidic mimic of the flow channels of a modular tissue engineered construct. Biomed Microdevices, 13(1):69-87, 2011.

[32] O. F. Khan, M. D. Chamberlain, and M. V. Sefton. Toward an in vitro vasculature: Differentiation of mesenchymal stromal cells within an endothelial cellseeded modular construct in a microfluidic flow chamber. Tissue Eng Part A, 2011.

[33] M. J. Butler and M. V. Sefton. Cotransplantation of adipose-derived mesenchymal stromal cells and endothelial cells in a modular construct drives vascularization in scid/bg mice. Tissue Eng Part A, 18(15-16):1628-41, 2012.

[34] A. P. McGuigan and M. V. Sefton. The thrombogenicity of human umbilical vein endothelial cell seeded collagen modules. Biomaterials, 29(16):2453-63, 2008.

[35] B. M. Leung and M. V. Sefton. A modular tissue engineering construct containing smooth muscle cells and endothelial cells. Ann Biomed Eng, 35(12):2039-49, 2007.

[36] I. Ferrenq, L. Tranqui, B. Vailhe, P. Y. Gumery, and P. Tracqui. Modelling biological gel contraction by cells: mechanocellular formulation and cell traction force quantification. Acta Biotheor, 45(3-4):267-93, 1997. 
[37] F. Zhao, R. Chella, and T. Ma. Effects of shear stress on 3-d human mesenchymal stem cell construct development in a perfusion bioreactor system: Experiments and hydrodynamic modeling. Biotechnol Bioeng, 96(3):584-95, 2007.

[38] A. Dickhut, K. Pelttari, P. Janicki, W. Wagner, V. Eckstein, M. Egermann, and W. Richter. Calcification or dedifferentiation: requirement to lock mesenchymal stem cells in a desired differentiation stage. J Cell Physiol, 219(1):219-26, 2009.

[39] J. Rouwkema, N. C. Rivron, and C. A. van Blitterswijk. Vascularization in tissue engineering. Trends Biotechnol, 26(8):434-41, 2008.

[40] R. W. Franz, A. Parks, K. J. Shah, T. Hankins, J. F. Hartman, and M. L. Wright. Use of autologous bone marrow mononuclear cell implantation therapy as a limb salvage procedure in patients with severe peripheral arterial disease. J Vasc Surg, 50(6):1378-90, 2009.

[41] K. Le Blanc. Mesenchymal stromal cells: Tissue repair and immune modulation. Cytotherapy, 8(6):559-61, 2006.

[42] M. M. Mueller and N. E. Fusenig. Friends or foes - bipolar effects of the tumour stroma in cancer. Nat Rev Cancer, 4(11):839-49, 2004. 



\title{
Chapter 6
}

\section{Boosting angiogenesis and functional vascularization in injectable dextran-hyaluronic acid hydrogels by endothelial-like mesenchymal stromal cells}

Karolina Janeczek Portalska, Liliana Moreira Teixeira, Jeroen C. H. Leijten, Rong Jin, Clemens van Blitterswijk, Jan de Boer and Marcel Karperien

\begin{abstract}
Angiogenesis and neo-vascularization are fundamental for the success of clinically relevant-sized tissue engineered (TE) constructs. The next generation of TE constructs relies on providing instructive materials combined with the delivery of angiogenic growth factors and cells to avoid tissue ischemia. However, the majority of materials and cell types screened so far show limited clinical relevance, either due to insufficient number of cells or due to the use of animal-derived matrixes. Here we investigated whether endothelial-like cells derived from mesenchymal stromal cells (ELMSC) can be used for vascular TE in combination with injectable dextran-hyaluronic acid hydrogels (Dex-g-HA). These hydrogels can be easily modified, as demonstrated by the incorporation of vascular endothelial growth factor (VEGF). We examined in vitro the reciprocal influences between cells and matrix. Dex-g-HA enabled higher EL-MSC metabolic rates associated with optimal cell sprouting in vitro, compared to HUVECs. In vivo evaluation demonstrated absence of an acute inflammatory response and EL-MSCs incorporated within Dex-g-HA formed a functional vascular network integrated with the host vascular system. This work demonstrates that Dexg-HA is an efficient delivery method of VEGF to induce angiogenesis. Additionally,
\end{abstract}


functional neo-vascularization can be achieved in vitro and in vivo by the combination of Dex-g-HA with EL-MSC.

\subsection{Introduction}

The survival of tissue engineered constructs of clinically relevant sizes is critically dependent on angiogenesis and neo-vascularization. Cell survival within large scaffolds upon implantation is largely hampered due to limited diffusion of oxygen and nutrients ultimately leading to tissue necrosis $1-3$. Vascular tissue engineering aims at establishing a vascular network in the tissue engineered construct which can rapidly connect to the host vasculature. New vessel formation can be enhanced by designing instructive materials containing supplying angiogenic growth factors [4] or by the inclusion of endothelial cells [5]. Combining both strategies would be highly beneficial for the survival of tissue engineered constructs.

Endothelial progenitor cells (EPC) are established cell candidates for vascularization in tissue engineering 6, 7]. These cells are reported to be able to differentiate into mature endothelial cells both in vitro and in vivo. Yet their expansion potential appears to be insufficient for therapeutic application, since it is difficult to maintain endothelial characteristics of EPCs during prolonged expansion in vitro 8, 9]. However, the cell main sources: umbilical-cord veins and aortas are not autologous to the patient. The clinical use of allogenic ECs is not possible due to chronic immune reactions 10,11. Consequently, there is great need for a novel vascularising cell source. We have recently developed a procedure for efficient differentiation of mesenchymal stromal cells (MSC) into endothelial-like MSCs (EL-MSCs) 12]. Unlike EPCs and ECs, MSCs can easily be isolated and are capable of being further expanded. EL-MSC are shown to induce functional vessel formation within engineered constructs [12]. Unfortunately, Matrigel Basement Membrane Matrix was necessary during the initial stages of the procedure. This prevents clinical translation as Matrigel is of a sarcoma origin it, is composed of a not fully defined composition and has a risk of pathogen transfer 13]. Therefore, another gel is needed to act as ECM for EL-MSCs.

Hydrogels are easily tunable to facilitate the formation of vasculature networks by providing instructive elements. We have recently addressed the enhancement of the biological properties of injectable enzymatically crosslinkable dextran-tyramine (Dex-TA) hydrogels by incorporating biofunctional polymers or by growth factor enrichment [14, 15. To further promote tissue infiltration and cell-mediated hydrogel degradation, we generated hybrid biomimetic hydrogels by engrafting Dex-TA on hyaluronic acid (HA) [16]. HA is a main player in several biological functions such as cell proliferation and migration, morphogenesis, healing, inflammation and angiogenesis. Moreover, HA oligosaccharides are involved in the stimulation of cytokine secretion and endothelial cell proliferation [17, 18].

Herein we evaluate the angiogenic potential of this biomimetic hydrogel scaffold in combination with vascularising cells. This combinatorial approach maximized the therapeutic potential of MSCs and EL-MSCs by inducing functional neo-vascularization. 


\subsection{Materials and Method}

\subsubsection{Cell isolation and culture}

An immortalized clone of human mesenchymal stromal cells (iMSCs, courtesy of Dr. Ola Myklebost, University of Oslo, Norway) and human umbilical vein endothelial cells (HUVEC, Lonza) were used. Cells were expanded as previously described [12].

\subsubsection{Endothelial induction of MSCs}

iMSCs (passage 25) were used for our endothelial induction protocol, as described previously $\left[12\right.$. Cells were seeded at a density of 3,000 cells per $\mathrm{cm}^{2}$ on tissue culture plastic in EGM-2 and cultured for 10 days. After one day in static culture, shear force was applied using an orbital shaker $(20 \mathrm{rpm})$. Cells that were cultured according to this protocol will be referred to as EL-MSCs.

\subsubsection{Synthesis of HA grafted with Dex-TA}

Copolymers of HA grafted with Dex-TA (Dextran-Tyramine), denoted as Dex-gTA, were synthesized by a coupling reaction of Dex-TA- $\mathrm{NH}_{2}$ (with primary amines) with HA using EDAC/NHS (Carbodiimide/N-Hydroxysuccinimide Ester) as coupling reagent, as previously described [16]. Briefly, amine-terminated dextran-tyramine conjugates (denoted as Dex-TA-NH2) were synthesized by a two-step procedure. Dex-TA conjugates were first reacted with $\mathrm{N}$-Boc-1,4-diaminobutane and sodium cyanoborohydride to end functionalize the dextran. In the second step, Dex-TA-NH-Boc (4.4 g) was dissolved in $110 \mathrm{ml}$ of deionized water and after addition of $4.4 \mathrm{ml}$ of TFA, the mixture was stirred overnight under nitrogen. Afterwards, sodium hyaluronate $(1 \mathrm{~g})$ was dissolved in $50 \mathrm{ml}$ of $\operatorname{MES}(0.1 \mathrm{M})$, to which EDAC $(9.4 \mathrm{mmol})$ and NHS (9.4 mmol) were added. After 30 minutes, a Dex-TA- $\mathrm{NH}_{2}$ solution was added and the mixture was stirred under nitrogen for 3 days. The number of grafted Dex-TA chains per HA molecule was determined using $1 \mathrm{H}$ NMR by comparing integrals of signals at $\delta 2.0$ (acetamide methyl protons of HA) and $\delta 5.0$ (dextran anomeric proton) and calculated to be 15. Enzymatic crosslinking was induced by HRP (Horseradish peroxidase) and $\mathrm{H}_{2} \mathrm{O}_{2}$ (hydrogen peroxide), using $0.25 \mathrm{mg} \mathrm{HRP}$ per mmol phenol groups and $\mathrm{H}_{2} \mathrm{O}_{2} /$ phenol molar ratio of 0.2 . The final concentration of Dex-g-HA hydrogels was $10 \mathrm{wt} \%$.

\subsubsection{Chorioallantoic membrane (CAM) model}

Fertilized eggs (local farm) were incubated at $37^{\circ} \mathrm{C}$ with $75 \%$ humidity. After 3 days, the eggs were punctured to remove $3 \mathrm{ml}$ of liquid. A rectangle was sawed off the eggshell, the window covered with tape and the viable eggs with a developing membrane were placed back into the incubator. On day 7, $100 \mu \mathrm{l}$ of Matrigel (BD Biosciences) or Dex-g-HA hydrogels, with and without VEGF, were placed in contact with the CAM. Eggs without hydrogels were considered the controls ( $n=3$ to 6 ). Four days after placing the hydrogels in contact with the membrane, images were collected. 
Additionally, after sacrificing the embryos by ethanol injection, the CAM with the hydrogel, fixated in 10\% formalin, was processed for further visualization.

\subsubsection{In vivo inflammatory response study}

The in vivo inflammatory response study was approved by the local animal ethical committee. Animal surgery and husbandry were performed in compliance with the regulations of the Central Laboratory Animal Institute (GDL), Utrecht University (Netherlands). The mice were anesthetized with an isofluorane/ $\mathrm{O}_{2}$ mixture. Hydrogel samples $(100 \mu \mathrm{l})$ were implanted subcutaneously in 8-weeks old wild-type male mice (Balb-c, Harlan). The same volume of polymer solution, without the addition of $\mathrm{HRP}$ and $\mathrm{H}_{2} \mathrm{O}_{2}$, was considered as the control. 1 week $(n=6)$ and 4 weeks $(n=6)$ post-implantation, the mice were euthanized via $\mathrm{CO}_{2}$ asphyxiation and samples with adjacent skin were harvested, fixed with $10 \%$ formalin and processed for histology.

\subsubsection{VEGF release profile}

Dex-g-HA hydrogels $(100 \mu \mathrm{l})$ were loaded with human VEGF (100 ng/ml, R\&D Systems), prior to gelation. After gelation, PBS $(100 \mu \mathrm{l})$ was added to each sample and incubated at $37^{\circ} \mathrm{C}$, under agitation. The supernatant was collected and the PBS refreshed at every time point, for 21 days. Release of VEGF-A isoform was quantified by ELISA, according to manufacturer's instructions (human DuoSet ELISA, calibrated against a highly purified Sf 21-expressed recombinant human VEGF $165, \mathrm{R} \& \mathrm{D}$ Systems). The cumulative release of VEGF is expressed as function of time.

\subsubsection{Cell encapsulation and culture}

Dex-g-HA polymer (10\% wt) was dissolved in PBS. HUVECs, iMSCs, EL-MCSs or co-cultures of iMSCs+EL-MCSs or iMSCs+HUVECs were incorporated in Dex-g-HA hydrogels at 10 million cells $/ \mathrm{ml}$. The cells were resuspended in the polymer solution and crosslinking was induced by the addition of $\mathrm{HRP}$ and $\mathrm{H}_{2} \mathrm{O}_{2}$ (constructs' final volume was $\mu \mathrm{l}$ ). Equal volumes of Matrigel with EL-MSCs and cells on tissue culture plastic (TCP) cultured in 2D served as controls. $100 \mathrm{ng} / \mathrm{ml}$ of VEGF was mixed in the polymer solution prior to gelation. The constructs were cultured in basic or EGM2 medium. Visualization and image acquisition were performed using Nikon Eclipse TE300. Pictures were taken at various time intervals (NikonDS-L2 camera).

\subsubsection{Cell viability, DNA quantification and metabolic activity}

A viability study on cells incorporated in Dex-g-HA hydrogels was performed with a live-dead assay and metabolic activity was assessed with the MTT assay. Data were normalized to the DNA content. For the Live/Dead assay, at day 14, the hydrogel constructs were stained with calcein AM/ethidium homodimer (Invitrogen), according to the manufacturer's instructions [19]. Hydrogel/cell constructs were visualized using fluorescence microscopy (Zeiss). The MTT staining was performed at day 14 (10\% MTT solution ( $5 \mathrm{mg} / \mathrm{ml}$, Gibco), 2 hours incubation, $\left.37^{\circ} \mathrm{C}\right)$. Hydrogel/cell constructs 
were then visualized under a microscope (Nikon SMZ-10A). To quantify metabolic activity of the cells encapsulated in the hydrogels, the constructs were incubated with $10 \%$ MTT solution ( 4 hours, $37^{\circ} \mathrm{C}$ ), the MTT/culture medium solution was removed and the formazan was extracted with DMSO. The quantification of formazan was performed with a microplate reader (Bio-TEK Instruments). Values were corrected for DNA content (CyQuant DNA kit), according to the manufacturer's description (Molecular Probes). The assays were performed after 1 and 14 days in culture.

\subsubsection{Histological evaluation in vitro}

Dex-g-HA-MSCs-constructs were cultured in basic medium, basic medium supplemented with 50ng/ml VEGF and in EGM-2 medium for 21 days, fixed in $10 \%$ formalin, embedded in cryomatrix (Cryomatrix, Shandon), cut in $10 \mu \mathrm{m}$ sections (cryomicrotome, Leica) and stained with either phalloidin conjugated with AlexaFluor 488 and counterstained with DAPI or hematoxylin and eosin (H\&E, Sigma-Aldrich) according to manufacturers' protocols. Samples were photographed using a Nikon Elipse E600 microscope.

\subsubsection{RNA isolation and quantitative PCR}

Total RNA was isolated (Nucleospin RNA II kit, Bioke) according to the manufacturer's protocol. First strand cDNA was synthesized (iScript, Invitrogen) according to the manufacturer's protocol. qPCR was performed in a $\mathrm{MyiQ}^{\mathrm{TM}}$ single-color real-time PCR detection system (BioRad). Expression of genes was calculated relative to major histocompatibility complex (B2M) levels by the comparative $\Delta \mathrm{CT}$ method. Primers used in the study are: CD31 F:5'-TCTATGACCTCGCCCTCCACAAA-3', R:5'-GA ACGGTGTCTTCAGGTTGGTATTTCA-3'; VEGF receptor 2 (KDR) F:5'-ACTTT GGAAGACAGAACCAAATTATCTC-3', R:5'-TGGGCACCATTCCACCA-3'; von Willebrand factor (vWF) F:5'-TGCTGACACCAGAAAAGTGC-3', R:5'-AGTCCC CAATGGACTCACAG-3'; B2M F:5'-GACTTGTCTTTCAGCAAGGA-3', R:5'-AC AAAGTCACATGGTTCACA-3'.

\subsubsection{Construct implantation}

Male 6-week old NMRI-nu mice (Harlan) were anesthetized with a mixture of isofluorane/oxygen, after which constructs were subcutaneously implanted in four pockets. Dex-g-HA gels without cells, with embedded HUVECs, with HUVECs together with MSCs, with MSCs alone, with combination of MSCs and EL-MSCs and with ELMSCs alone were implanted. Two weeks after implantation, the mice were sacrificed and implants were recovered $(n=6)$, fixed in $10 \%$ formalin, embedded in paraffin and sectioned at $5 \mu \mathrm{m}$ before staining.

\subsubsection{Histochemical analysis of implanted constructs}

H\&E staining and Masson's trichrome (Merck Chemicals) staining were performed according to manufacturers' protocols. Samples were photographed using a Nikon 
Elipse E600 microscope. Based on Masson's trichrome staining vessels were counted manually by 3 people blinded to the sample composition. Six areas of each sample (6 samples per condition) were used per quantification.

For CD31 staining antigen retrieval was performed with IHC-Tek Epitope Retrieval Solution (IHC World). Sections were then incubated with mouse-anti-human CD31 primary antibody (Dako), which does not cross-react with mouse tissue. Afterwards, biotinylated horse anti-mouse secondary antibody (Antibodies-online.com) was applied. Slides were developed with the Labeled Streptavidin Biotin (LSAB) method with DAB Chromogen (IHC World) and weakly counterstained with Mayer's hematoxylin (Sigma-Aldrich).

\subsubsection{Statistics}

Each experiment was performed in triplicate. Data requiring multiple comparison test was analysed in SPSS (PASW statistics) using one-way Anova followed by Tukey's multiple comparison test $(\mathrm{P}<0.05)$.

\subsection{Results}

\subsubsection{Hydrogel integration in vascular network and inflammatory response}

First, we evaluated the interaction of Dex-g-HA hydrogels with a developing vasculature system using the chick CAM model [20]. Dex-g-HA with and without VEGF was compared to a negative control without any implant and to Matrigel, commonly used matrix for EC culture and encapsulation (Figure 6.1A). We observed that the Matrigel samples did not adhere to the chick membrane resulting in no interaction with the forming vasculature. In contrast, Dex-g-HA showed integration with the membrane by attachment and orientation of the forming blood vessels. Intricate vasculature formation was particularly visible around Dex-g-HA hydrogel loaded with VEGF.

We evaluated the immune response towards Dex-g-HA by subcutaneous implantation in mice. The inflammatory response for both hydrogels and polymer precursor (Dex-g-HA without HRP and $\mathrm{H}_{2} \mathrm{O}_{2}$ ) was assessed based on the thickness of fibrous tissue layer and the abundance of extravasated immune cells, 7 and 28 days postimplantation (Figure 6.1B). After 7 days, capsule formation was detected around the hydrogels, whereas no reaction occurred when the polymer alone was injected. At day 28 , the capsule detected earlier showed a clear reduction in thickness. This is a typical sign of a foreign body response and not of an acute inflammatory response.

\subsubsection{VEGF incorporation in Dex-g-HA}

To enhance angiogenesis, VEGF was incorporated in the Dex-g-HA hydrogel network prior to gelation. Quantification of the VEGF released from the hydrogel was assessed 
A
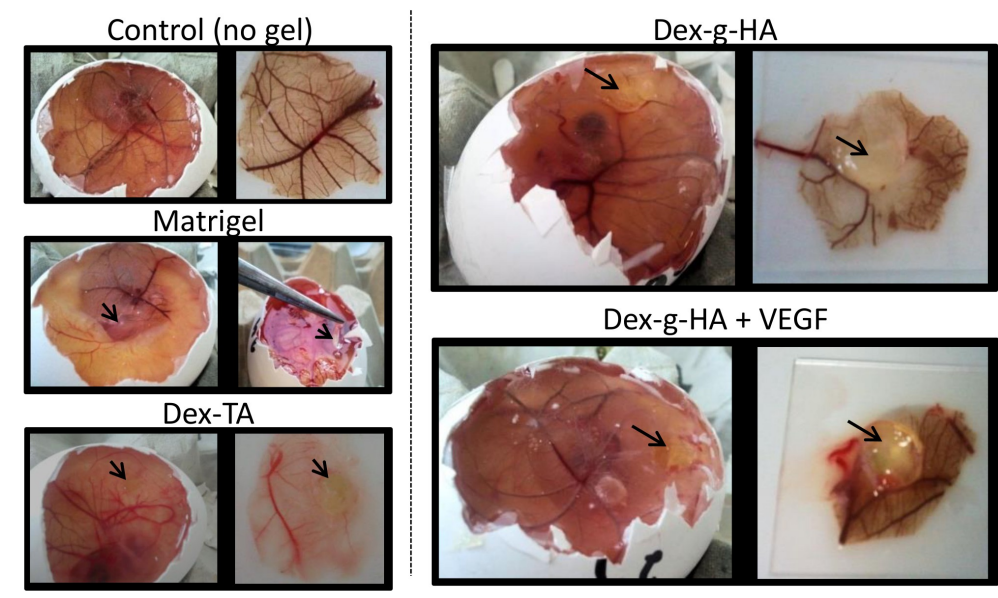

B
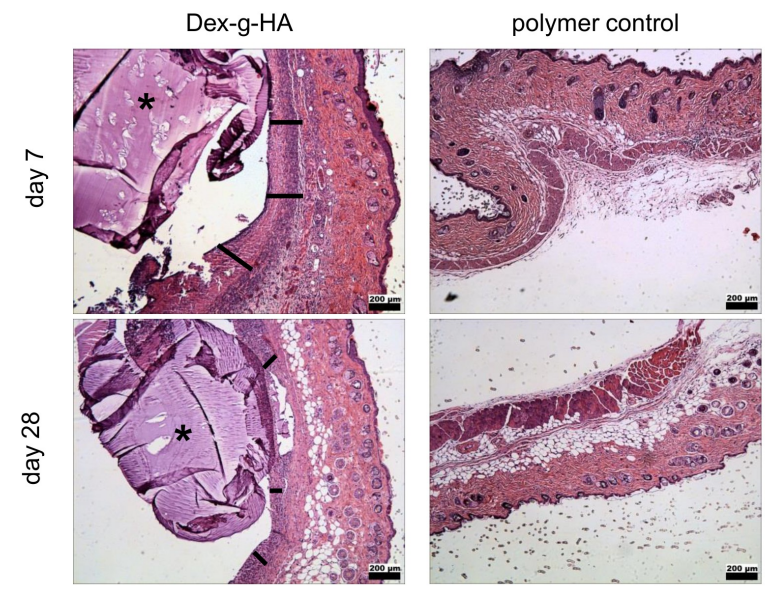

Figure 6.1: Dex-g-HA hydrogel characterization. CAM assay of dextran gel engrafted with HA with or without VEGF and Matrigel (A). Gels were placed in open window in viable eggs and incubated for 4 days. After that representative pictures were taken and vessel ingrowth in the sample was compared. Black arrows indicate gel position. Dextran in vivo characterization: inflammatory response (B). Dex-g-HA and polymer solution (without the addition of $\mathrm{HRP}$ and $\left.\mathrm{H}_{2} \mathrm{O}_{2}\right)$ was implanted for 1 week and 4 weeks $(n=6)$, after that samples were recovered and examined. Dex-g-HA gel is marked with $\mathrm{a}^{*}$, black line indicates the thickness of fibrous tissue.

by ELISA and the cumulative release profile was determined up to 21 days (Figure 6.2. VEGF concentration of $100 \mathrm{ng} / \mathrm{ml}$ was chosen based on previous studies sug- 
gesting that such concentration was likely to enhance ECs' mitogenic and sprouting potential 21. Two distinct phases can be identified in the release profile, consisting of an initial burst release of the VEGF occurring in the first 100 hours, followed by a continuous yet low release until the last day of assessment. At day 21, $65 \%$ of the incorporated VEGF was released. Remaining 35\% was still entrapped in the gel or could not be detected.

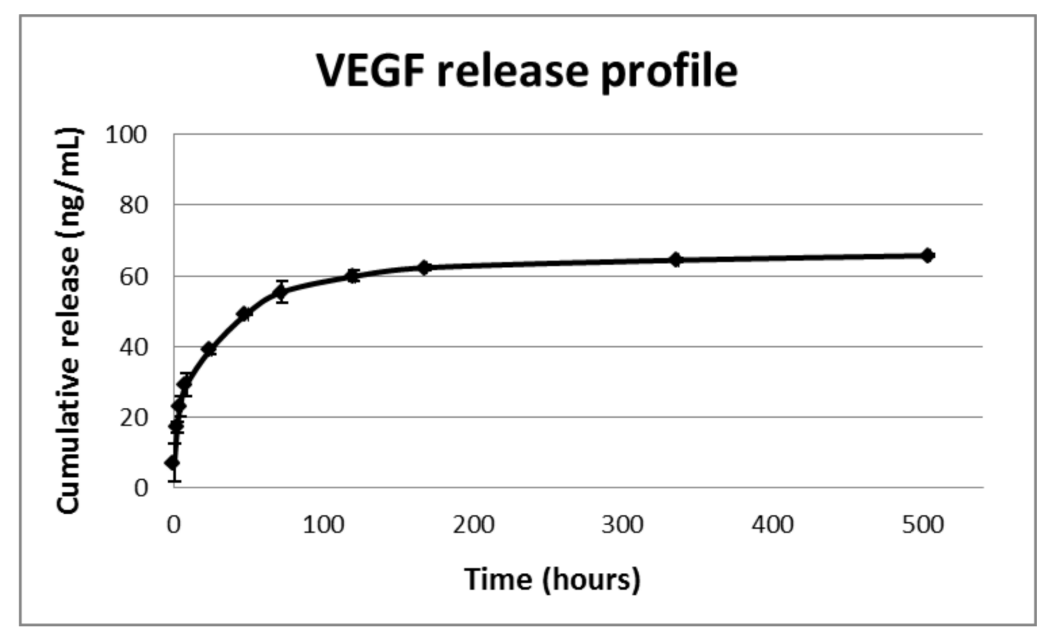

Figure 6.2: Release profile of VEGF from Dex-g-HA hydrogel. $\mathrm{Cu}-$ mulative release of VEGF from Dex-g-HA hydrogels monitored over 21 days. Initial concentration of VEGF was $100 \mathrm{ng} / \mathrm{ml}$. Indicated values represent mean $(\mathrm{n}=3)$.

\subsubsection{Cell viability and metabolic activity within Dex-g-HA}

To confirm the absence of cytotoxicity of Dex-g-TA upon cell encapsulation and culture, we assessed the viability and metabolic activity of HUVECs, MSCs and ELMSCs. We showed that no cytotoxicity was induced after 14 days in culture (Figure 6.3A). Only a limited amount of dead cells (red) could be detected when HUVECs were cultured for 14 days. The MSCs and EL-MSCs were fully viable (green) and uniformly distributed throughout the Dex-g-HA hydrogel.

Cells' metabolic activity was initially assessed using MTT staining. After 14 days of culture, both MSCs and EL-MSCs were more metabolically active than HUVECs (Figure 6.3B). The quantification of this phenomenon (Figure 6.3 C) demonstrated that the metabolic activity of HUVECs per cell is initially twice as high as the activity of MSCs and EL-MSCs. At day 14, we observed a significant decrease in metabolic activity of HUVECs. In contrast, the metabolic activity of both MSCs and EL-MSCS increased significantly from day 1 to day 14. This increase was more pronounced with 
A

HUVEC

MSC

EL-MSC
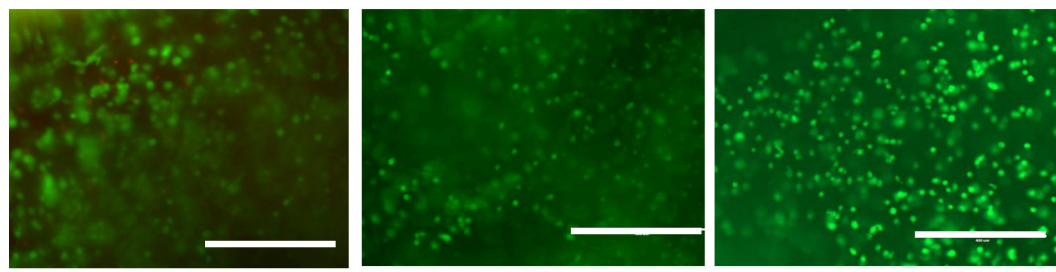

B
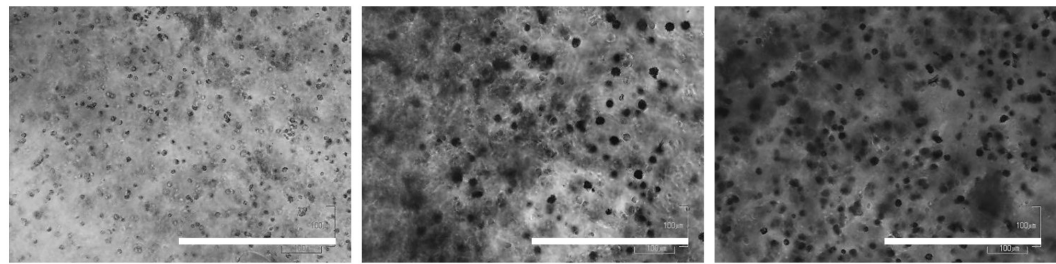

C

\section{MTT/DNA}

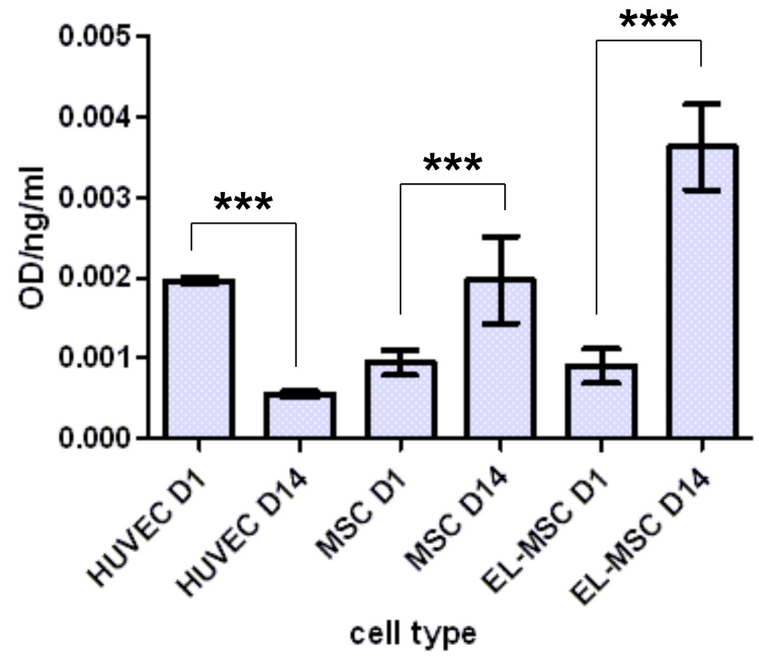

Figure 6.3: Cells in Dex-g-HA hydrogel. In vitro characterization two weeks after seeding: live dead assay after 14 days in culture (A), MTT staining after 14 days in culture (B). Metabolic activity of cells in Dex-g-HA 1 and 14 days after seeding corrected for cell number (C). Scale bar $400 \mu \mathrm{m}$. Indicated values represent mean $(\mathrm{n}=3)$ with standard deviation, $* * *$ denotes statistical significance $(\mathrm{P}<0.001)$.

EL-MSCs, which suggests that they have a superior metabolic performance compared to MSCs when incorporated in Dex-g-HA for prolonged culture. 


\subsubsection{Capillary network assembly in Dex-g-HA}

As next step, we evaluated the influence of Dex-g-HA on the behaviour of cells grown within it. Consistent with the results of MTT assay, we did not find any evidence of HUVEC activity within Dex-g-HA. ECM remodeling was not detected in gel samples with HUVECs as indicated by lack of sprouting and capsule formation. Interestingly, this was not the case when gels containing MSCs and EL-MSCs were examined. On day 21 of in vitro culture tubulogenesis was observed in the form of sprouting and branching (Figure 6.4A).

We applied different media to determine major factors influencing capillary network formation. Our results suggest that the level of FBS in the medium is of major importance. Cells cultured in EGM-2 with $2 \%$ FBS content sprouted less efficiently than cells cultured in basic medium with $10 \%$ FBS. Moreover, addition of VEGF to the gel clearly boosted sprouting (Figure 6.4 B). Nevertheless, even in conditions without additional growth factors, capillaries with lumens were observed, proving the potential of Dex-g-HA hydrogels to support cell sprouting.

\subsubsection{Molecular profile and vascular morphogenesis of cells}

We characterized the gene expression profile of cells seeded in Dex-g-HA hydrogels. At day 7 of in vitro culture, we observed that expression of endothelial markers CD31, KDR and $v W F$ in HUVECs seeded in the gel is lower than in HUVECs seeded on TCP (considered as control). Nevertheless, at day 14 the expression level of these markers within the gels matched the control and kept on increasing (day 21), reaching 8 fold induction (day 28) (Figure 6.5).

Very promising results were also obtained after endothelial induction of MSCs within Dex-g-HA hydrogels. Endothelial gene expression in both MSCs and in ELMSCs was presented as fold induction compared to cells cultured on TCP. Our previous study [12] showed that in TCP culture neither MSCs nor EL-MSCs express any of the studied markers, while Matrigel stimulation can induce the cells towards an endothelial-like phenotype. Our results show that Dex-g-HA can substitute Matrigel. For both MSCs and EL-MSCs, the expression of CD31 and KDR was increased after 21 days of culture within Dex-g-HA gels. Consistent with our previous results [12], the MSCs used in this study did not show any induction in vWF expression neither in Matrigel nor in Dex-g-HA (Figure 6.5).

\subsubsection{Functional vascular network formation within dex-g-HA hydrogels}

To determine whether cells embedded in Dex-g-HA hydrogels can stimulate vascular network formation, we implanted into nude mice Dex-g-HA gels in six variants, namely without cells, with embedded HUVECs, with both HUVECs and MSCs, with MSCs alone, with a combination of MSCs and EL-MSCs and with EL-MSCs alone. Two weeks after implantation hardly any vessels were observed within empty gels, as well 
A

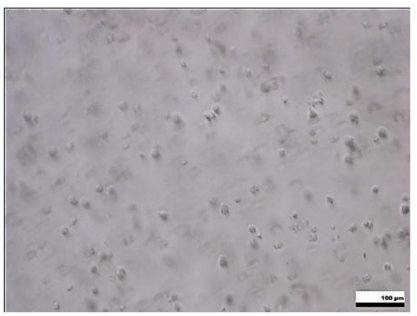

B
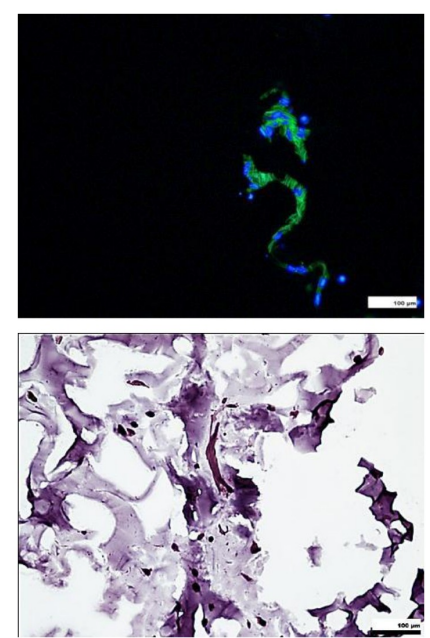

MSC

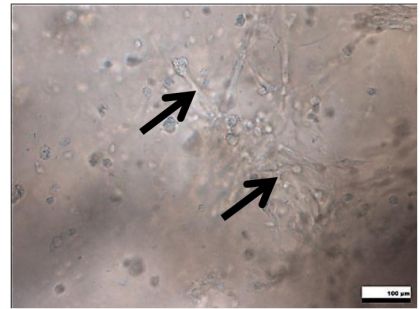

basic
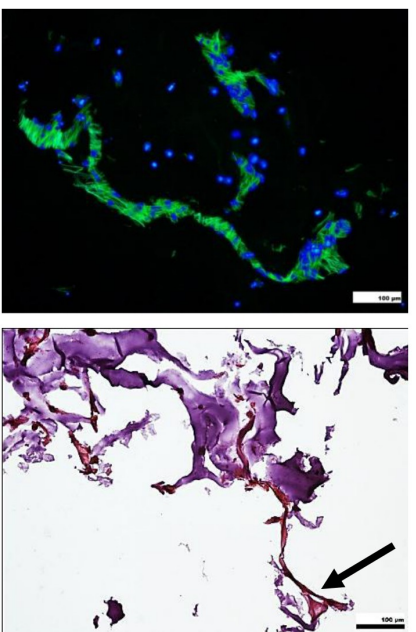

ELMSC

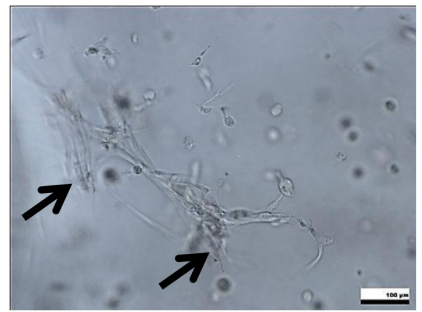

basic + VEGF
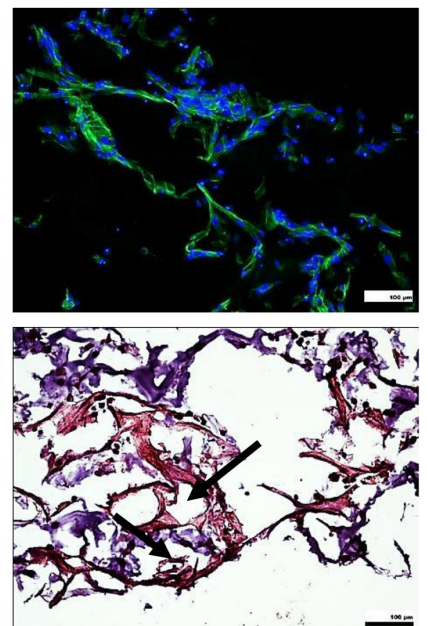

Figure 6.4: Cells in Dex-g-HA hydrogels after 21 days of in vitro culture. Phase-contrast microscopy microphotograph of cell monoculture in Dex-g-HA hydrogel (A). Sprouting cells forming capillary-like structures are indicated by black arrows. Influence of culture conditions for MSC morphology after 21 days of in vitro culture (B). The effect of introduction of VEGF in Dex-g-HA hydrogel was accessed to determine its contribution to the formation of the capillary-like structures. Lumens are indicated by arrows. Scale bar 100 $\mu \mathrm{m}$.

as within constructs with embedded HUVECs and HUVECs/MSCs. On the other hand, in constructs with embedded MSCs, MSCs/EL-MSCs and EL-MSCs, vessels were present in the gels in the periphery and in the middle of the sample (Figure 6.6A).

Quantification of vascular network confirmed these observations. No significant differences were found between samples with empty gel, gel with HUVECs or HU- 

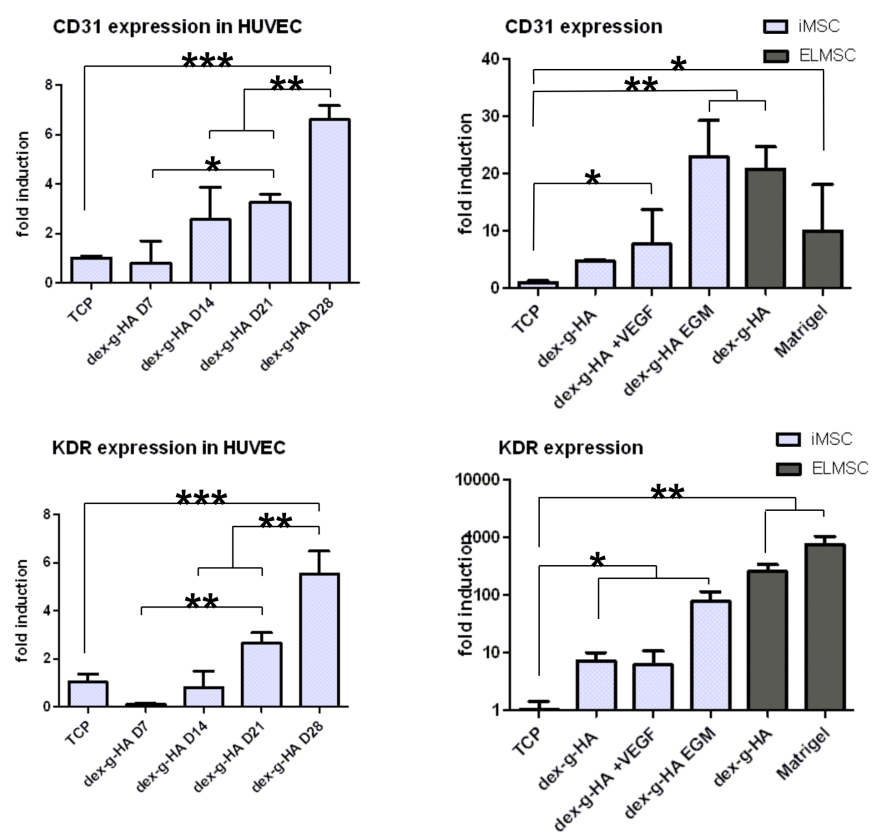

vWF expression in HUVEC

vWF expression
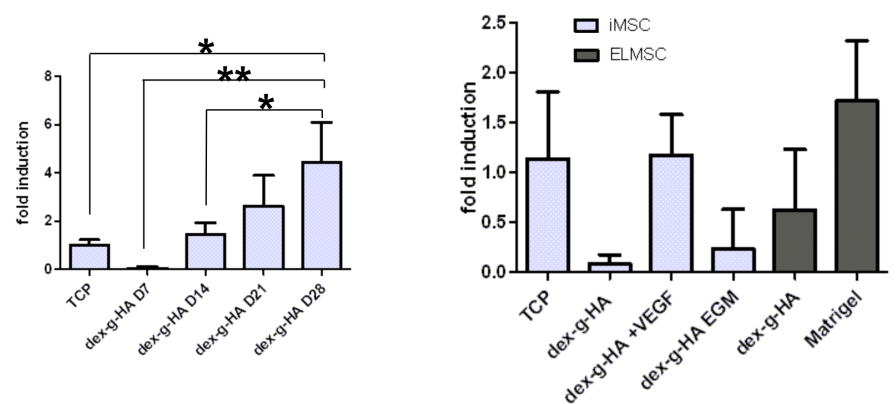

Figure 6.5: Endothelial marker expression in cells cultured in Dex-gHA. Gene expresion is represented as fold induction compared to cells seeded on tissue culture plastic (HUVECs and MSCs). CD31, KDR and vWF expression were observed at four time points in case of $\operatorname{HUVEC}$ culture $(7,14,21$ and 28 days) and at one time point (21 days) in case of MSC and EL-MSC culture. VEGF was incorporated in the Dex-g-HA hydrogel to determine its influence on the endothelial marker expression. Indicated values represent mean $(\mathrm{n}=3)$ with standard deviation. ${ }^{*}$ denotes statistical significance $(\mathrm{P}<0.05), * *$ denotes statistical significance $(\mathrm{P}<0.01), 6^{* * *}$ denotes statistical significance $(\mathrm{P}<0.001)$. 

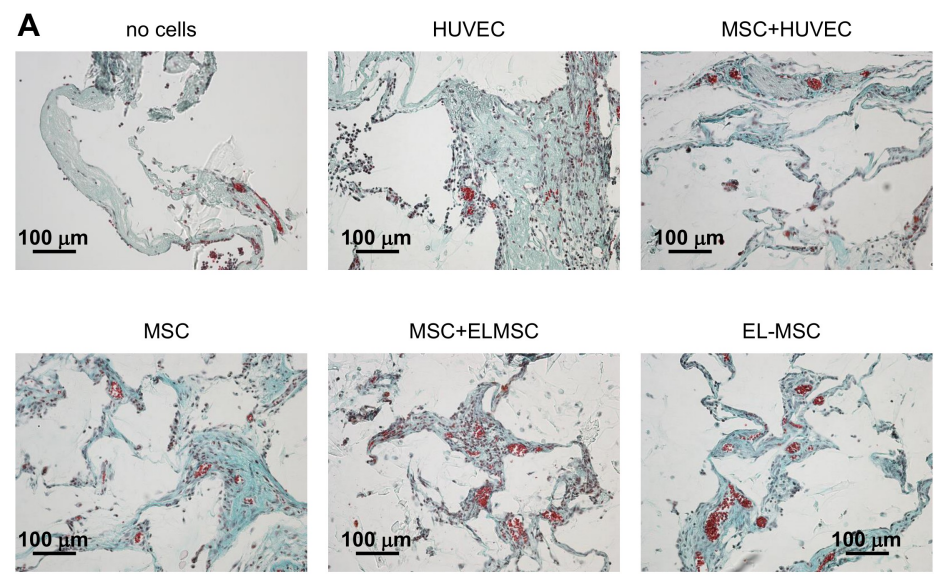

\section{B}

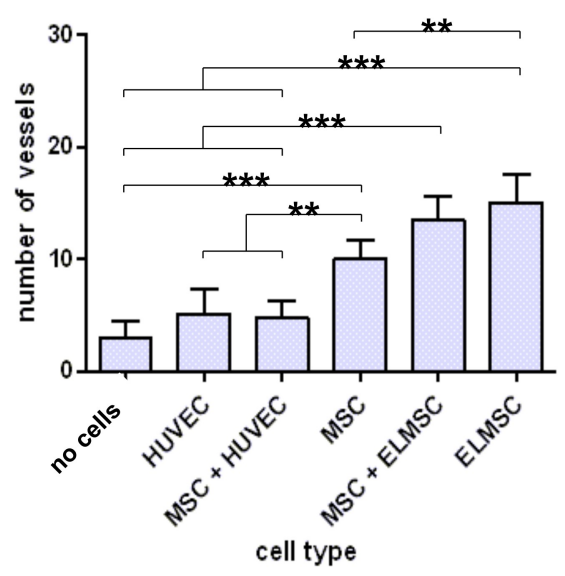

Figure 6.6: In vivo vascularization of Dex-g-HA construct combined with cells. Vessel in-growth in vivo in 3D constructs. Tissue construct sections were stained with Masson's trichrome staining (blue for collagen, red for erythrocytes) and counterstained with hematoxylin (brown) (A). Quantitative analysis of vessels in Dex-g-HA constructs (B). Number of vessels per sample was quantified by three people blinded for the conditions. ${ }^{* *}$ denotes statistical significance $(\mathrm{P}<0.01)$, *** denotes statistical significance $(\mathrm{P}<0.001)$.

VECs/MSCs. Embedded MSCs significantly stimulated host vessel formation in the construct and the effect was further improved by addition of EL-MSCs. Compared to other conditions, the highest number of vessels was observed in gels with embedded EL-MSCs (Figure 6.6B). 
To determine whether the implanted cells participated in vessel formation, human CD31 staining was performed. CD31 positive cells were observed in constructs seeded with all cell types (Figure 6.7). CD31 positive lumens were observed only in three of the tested conditions, namely in samples with HUVECs+MSCs, with EL-MSCs and with EL-MSCs+MSCs. The majority of vessels in the gels did not stain positive for human CD31. This suggested that these vessels were derived from ingrowing mouse endothelial cells, which was mostly stimulated in gels loaded with EL-MSCs.
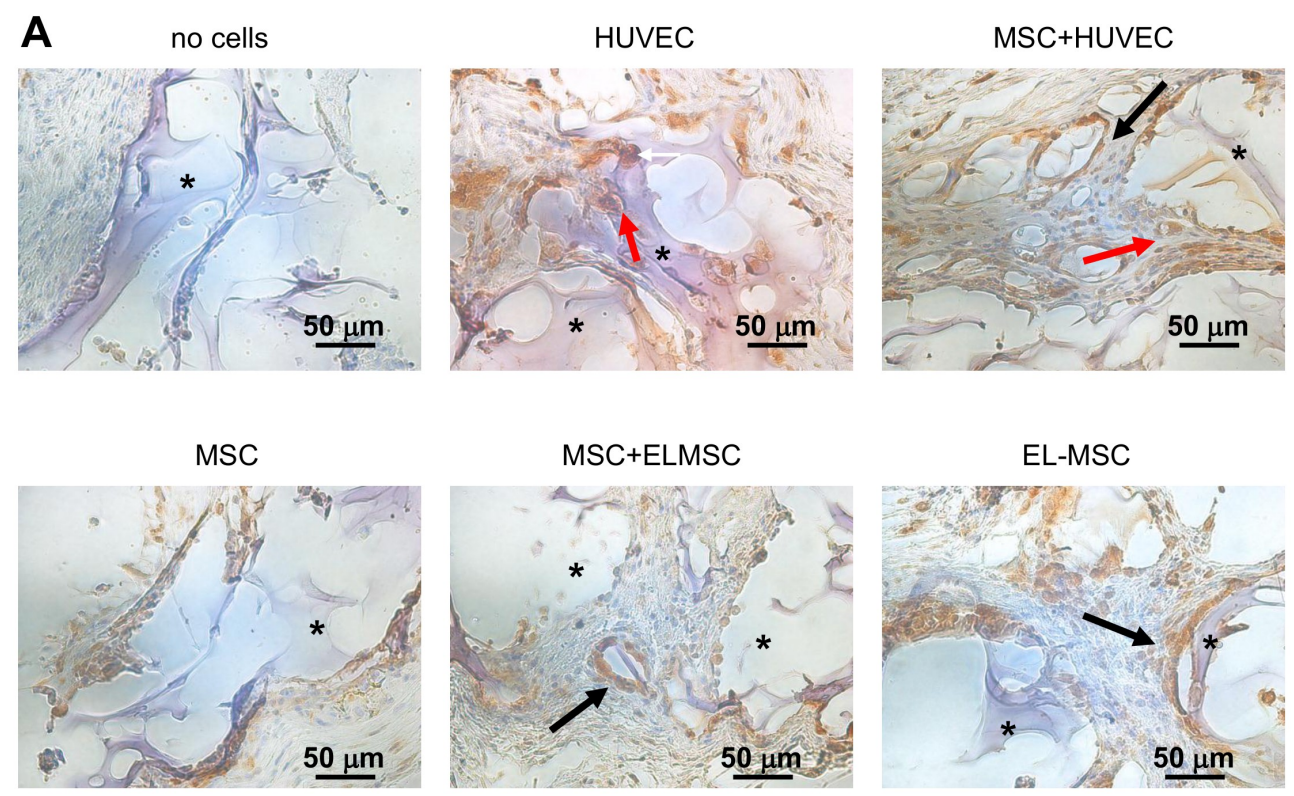

Figure 6.7: CD31 staining in Dex-g-HA constructs. Immunohistochemistry was used to stain for human CD31. Dex-g-HA is stained blue (*), CD31 positive cells are brown, aggregates of HUVEC are indicated by red arrows, CD31 positive lumens are indicated by black arrows.

\subsection{Discussion}

Tissue engineered constructs require proper vascularization for a successful therapeutic use. Since the contribution of ECM components in regulation of vascularization is widely recognized [22, 23], there is a need to provide clinically relevant matrixes which accelerate vessel in-growth and, improve cell survival. In this study, we exploited an injectable HA-based biomimetic hydrogel to encapsulate different cell types, ultimately determining the cell-biomaterial combination that showed superior angiogenic potential.

The biomaterial reported herein is a hybrid of HA, a key ECM instructive component directing proliferation, migration and angiogenesis 24], and dextran, recently 
reported as a promising biomaterial to enhance neo-vascularization 25, 26]. We have also entrapped VEGF in Dex-g-HA hydrogel further boosting cell survival and tissue formation. We demonstrated that Dex-g-HA, with and without incorporation of VEGF, enabled the formation of blood vessels. Evaluation of the immune response triggered by Dex-g-HA revealed an absence of an acute inflammatory response. These highly favourable results are strongly indicative of the biocompatibility of the biomaterial chosen, as shown previously 24, 26.

An important finding in our study was the possibility to incorporate VEGF in the Dex-g-HA. It has been previously reported that VEGF incorporated in HA-containing hydrogels induces the production of metalloproteinases [27, which actively contribute to the ECM remodelling. The presence of VEGF causes the reduction of ECM mechanical resistance, allowing cells to migrate and reorganize. We used VEGF for proofof-principle, demonstrating that it is achievable to incorporate pro-angiogenic factors in this matrix system. The achieved pattern of first bursty followed by steady VEGF release is highly desirable, since a high VEGF concentration is particularly important during the initial stages of scaffold implantation to trigger angiogenesis and neo-vasculature formation [21].

Another issue underlying construct vascularization is the selection of cells to create vessel network. Widely investigated endothelial or endothelial progenitor cells so far did not meet expectations due to: a) problems with isolation of large quantities of autologous cells; b) immune-rejection of allogenic cells; and c) expansion of these cells without losing their differentiation capacity in both cases 28. Therefore, we propose another cell type, namely MSCs, whose pro-angiogenic paracrine effect and potential to become endothelial-like cells has been shown lately by several groups including our own [12, 29 31]. We have explored the potential of MSCs in two ways: triggering the commitment into the endothelial lineage and as a powerful enhancer of angiogenesis in a co-culture environment.

Although many studies focus on the effect of the biomaterial on cell viability, none of them compares the metabolic activity per cell using different cell types. Our results showed that all analysed cell types: MSCs, HUVECs and EL-MSCs, incorporated in Dex-g-HA and cultured in vitro were fully viable. Interestingly, HUVECs showed very low metabolic activity rates at later time points, likely due to their inability to remodel the surrounding matrix or lack of stimulation to interact with it. The opposite observation was made for EL-MSCs, which showed the highest metabolic rate after 14 days in culture. This significant increase strongly suggested that EL-MSCs are able to interact well with the Dex-g-HA. This is highly advantageous, as metabolically active cells are expected to interact more intensively with the surrounding matrix, by enhanced proliferation, migration and/or matrix remodelling [32,33. More active cells are likely to contribute more to the development of a vascular network via for example by higher secretion of pro-angiogenic factors. As the vascular inductive effect of the Dex-g-HA gel represents one of the most innovative aspect of the present work, we propose two types of mechanisms that might justify the observed results: a) unique 
hypoxic conditions created within this gel type, and/or b) the degradation products of hyaluronic acid are strongly triggering a pro-angiogenic response.

To generate a gel suitable for use in vascular tissue engineering, several modifications such as integrin binding domain or growth factor introduction have been studied [34, 35]. In our work we demonstrate that MSCs and EL-MSCs do not require complicated gel modifications to interact with the hydrogel, sprout, and ultimately form a blood vessel. Additional introduction of VEGF in the system further improved the ability of those cells to form capillary-like structures. This result showed higher capabilities of both naïve and differentiated MSCs for to interaction with matrix as compared to endothelial cells like HUVECs. Furthermore, we showed that Dex-gHA-induced changes in the molecular profile of MSCs and EL-MSCs were similar to the ones induced by Matrigel. Chemically defined Dex-g-HA can, therefore, replace undefined Matrigel in endothelial differentiation of MSCs. Additionally, although HUVECs within the Dex-g-HA did not sprout, constant increase in endothelial marker expression proved that these cells were not senescent.

Once implanted in vivo, Dex-g-HA constructs were stable and did not show morphological signs of fast degradation in the host tissue. In constructs without cells or seeded with HUVECs host tissue and vessels did not grow into the gel. This effect is in line with the in vitro data, where we showed that HUVECs have a low metabolic activity within Dex-g-HA, probably followed by decreased amount of released pro-angiogenic factors. In constructs with MSCs or EL-MSCs, the trophic effect of incorporated cells was much higher, boosting angiogenesis from host blood vessels. As expected, EL-MSCs were most efficient in attracting vessel ingrowth. Nonetheless, MSC influence on the number of vessels within the construct was also beneficial as compared to both empty and HUVEC-seeded gels. MSCs are known to secrete a wide range of cytokines and growth factors, which have both immunomodulatory and regenerative properties 31]. It is likely that the trophic effect of EL-MSCs is even larger, since these cells were cultured in growth factor-rich medium that can induce additional pro-angiogenic molecule secretion. The fact that constructs seeded with a combination of HUVECs and MSCs were not penetrated by host tissue and vessels is probably a result of decreased MSC number in the construct. Since HUVECs alone were shown to not have any effect on construct vascularization, decreasing the number of MSCs was likely to reduce their beneficial influence. Human CD31 staining was performed to determine whether seeded cells played more than a trophic role in attracting vessel in-growth. This led to the observation that HUVECs within the Dexg-HA tended to form aggregates. In samples seeded only with HUVECs, no human CD31 positive lumens were observed. Similar results were obtained with constructs seeded only with MSCs, as we found CD31 positive cells, which did not form lumens. Opposite results were obtained when HUVECs and MSCs were seeded together. In these conditions, both CD31 positive aggregates and CD31 positive lumens were observed. These results may have two possible explanations: a) the presence of MSCs caused sufficient matrix remodeling to allow HUVECs to spread and form lumens, or b) MSCs benefited from the influence of HUVECs. The second hypothesis can be supported by previous study of Rouwkema et al. [36], reporting that MSCs cultured 
in the presence of HUVECs started to express endothelial markers. This effect was suggested to be caused both by cell-to-cell contact and by trophic effects. When ELMSCs were present, both single CD31 positive cells as well as CD31 positive lumens were observed. This allows us to conclude that EL-MSCs can be used without any supporting cells to create vessel network within tissue engineered constructs.

In conclusion, Dex-g-HA injectable hydrogels are capable of sustaining neo-vasculature formation both in vitro and in vivo, and can be used as an effective delivery method of VEGF to induce angiogenesis. Additionally, combining Dex-g-HA with EL-MSCs enables higher cell metabolic rates. This effect leads to increased secretion of proangiogenic factors associated with optimal cell sprouting in vitro, ultimately leading to improved neo-vasculature formation in vivo. The boost in angiogenesis and vessel ingrowth in EL-MSCs loaded hydrogels is due to 1) endothelial differentiation of these cells and 2) due to increased trophic potential. This strategy can be applied in combination with other scaffolds or by itself to avoid or reverse tissue ischemia. 


\subsection{Bibliography}

[1] M. Radisic, J. Malda, E. Epping, W. Geng, R. Langer, and G. Vunjak-Novakovic. Oxygen gradients correlate with cell density and cell viability in engineered cardiac tissue. Biotechnol Bioeng, 93(2):332-43, 2006.

[2] J. Rouwkema, N. C. Rivron, and C. A. van Blitterswijk. Vascularization in tissue engineering. Trends Biotechnol, 26(8):434-41, 2008.

[3] M. Lovett, K. Lee, A. Edwards, and D. L. Kaplan. Vascularization strategies for tissue engineering. Tissue Eng Part B Rev, 15(3):353-70, 2009.

[4] T. P. Richardson, M. C. Peters, A. B. Ennett, and D. J. Mooney. Polymeric system for dual growth factor delivery. Nat Biotechnol, 19(11):1029-34, 2001.

[5] S. Levenberg, J. Rouwkema, M. Macdonald, E. S. Garfein, D. S. Kohane, D. C. Darland, R. Marini, C. A. van Blitterswijk, R. C. Mulligan, P. A. D'Amore, and R. Langer. Engineering vascularized skeletal muscle tissue. Nat Biotechnol, 23(7):879-84, 2005.

[6] J. Rouwkema, P. E. Westerweel, J. de Boer, M. C. Verhaar, and C. A. van Blitterswijk. The use of endothelial progenitor cells for prevascularized bone tissue engineering. Tissue Eng Part A, 15(8):2015-27, 2009.

[7] G. Krenning, M. J. van Luyn, and M. C. Harmsen. Endothelial progenitor cellbased neovascularization: implications for therapy. Trends Mol Med, 15(4):180-9, 2009.

[8] M. Hristov, W. Erl, and P. C. Weber. Endothelial progenitor cells: mobilization, differentiation, and homing. Arterioscler Thromb Vasc Biol, 23(7):1185-9, 2003.

[9] M. Hristov and C. Weber. The therapeutic potential of progenitor cells in ischemic heart disease-past, present and future. Basic Res Cardiol, 101(1):1-7, 2006 .

[10] R. N. Salomon, C. C. Hughes, F. J. Schoen, D. D. Payne, J. S. Pober, and P. Libby. Human coronary transplantation-associated arteriosclerosis. evidence for a chronic immune reaction to activated graft endothelial cells. Am J Pathol, 138(4):791-8, 1991.

[11] R. M. Nerem and D. Seliktar. Vascular tissue engineering. Annu Rev Biomed Eng, 3:225-43, 2001.

[12] K. Janeczek Portalska, A. Leferink, N. Groen, H. Fernandes, L. Moroni, C. van Blitterswijk, and J. de Boer. Endothelial differentiation of mesenchymal stromal cells. PLoS One, 7(10):e46842, 2012.

[13] G. D. Prestwich. Simplifying the extracellular matrix for 3-d cell culture and tissue engineering: a pragmatic approach. J Cell Biochem, 101(6):1370-83, 2007. 
[14] R. Jin, L. S. Moreira Teixeira, P. J. Dijkstra, C. A. van Blitterswijk, M. Karperien, and J. Feijen. Chondrogenesis in injectable enzymatically crosslinked heparin/dextran hydrogels. J Control Release, 152(1):186-95, 2011.

[15] L. S. Moreira Teixeira, J. C. Leijten, J. W. Wennink, A. G. Chatterjea, J. Feijen, C. A. van Blitterswijk, P. J. Dijkstra, and M. Karperien. The effect of platelet lysate supplementation of a dextran-based hydrogel on cartilage formation. Biomaterials, 33(14):3651-61, 2012.

[16] R. Jin, L. S. Teixeira, P. J. Dijkstra, C. A. van Blitterswijk, M. Karperien, and J. Feijen. Enzymatically-crosslinked injectable hydrogels based on biomimetic dextran-hyaluronic acid conjugates for cartilage tissue engineering. Biomaterials, 31(11):3103-13, 2010.

[17] D. Hanjaya-Putra, K. T. Wong, K. Hirotsu, S. Khetan, J. A. Burdick, and S. Gerecht. Spatial control of cell-mediated degradation to regulate vasculogenesis and angiogenesis in hyaluronan hydrogels. Biomaterials, 33(26):6123-31, 2012.

[18] F. E. Lennon and P. A. Singleton. Hyaluronan regulation of vascular integrity. Am J Cardiovasc Dis, 1(3):200-13, 2011.

[19] Jojanneke M. Jukes, Lorenzo Moroni, Clemens A. van Blitterswijk, and Jan de Boer. Critical steps toward a tissue-engineered cartilage implant using embryonic stem cells. Tissue Eng. A, 14(1):135-147, 2008.

[20] Desmond B. S. Pink, Wendy Schulte, Missag H. Parseghian, Andries Zijlstra, and John D. Lewis. Real-time visualization and quantitation of vascular permeability ¡italic ¿in vivoj/italic ¿̨: Implications for drug delivery. PLoS One, 7(3):e33760, 2012.

[21] E. A. Silva and D. J. Mooney. Effects of vegf temporal and spatial presentation on angiogenesis. Biomaterials, 31(6):1235-41, 2010.

[22] G. E. Davis, W. Koh, and A. N. Stratman. Mechanisms controlling human endothelial lumen formation and tube assembly in three-dimensional extracellular matrices. Birth Defects Res C Embryo Today, 81(4):270-85, 2007.

[23] E. Kniazeva and A. J. Putnam. Endothelial cell traction and ecm density influence both capillary morphogenesis and maintenance in 3-d. Am J Physiol Cell Physiol, 297(1):C179-87, 2009.

[24] D. Hanjaya-Putra, V. Bose, Y. I. Shen, J. Yee, S. Khetan, K. Fox-Talbot, C. Steenbergen, J. A. Burdick, and S. Gerecht. Controlled activation of morphogenesis to generate a functional human microvasculature in a synthetic matrix. Blood, 118(3):804-15, 2011.

[25] L. S. Ferreira, S. Gerecht, J. Fuller, H. F. Shieh, G. Vunjak-Novakovic, and R. Langer. Bioactive hydrogel scaffolds for controllable vascular differentiation of human embryonic stem cells. Biomaterials, 28(17):2706-17, 2007. 
[26] G. Sun, Y. I. Shen, S. Kusuma, K. Fox-Talbot, C. J. Steenbergen, and S. Gerecht. Functional neovascularization of biodegradable dextran hydrogels with multiple angiogenic growth factors. Biomaterials, 32(1):95-106, 2011.

[27] D. Hanjaya-Putra, J. Yee, D. Ceci, R. Truitt, D. Yee, and S. Gerecht. Vascular endothelial growth factor and substrate mechanics regulate in vitro tubulogenesis of endothelial progenitor cells. J Cell Mol Med, 14(10):2436-47, 2010.

[28] W. J. Zhang, W. Liu, L. Cui, and Y. Cao. Tissue engineering of blood vessel. J Cell Mol Med, 11(5):945-57, 2007.

[29] J. Oswald, S. Boxberger, B. Jorgensen, S. Feldmann, G. Ehninger, M. Bornhauser, and C. Werner. Mesenchymal stem cells can be differentiated into endothelial cells in vitro. Stem Cells, 22(3):377-84, 2004.

[30] J. W. Liu, S. Dunoyer-Geindre, V. Serre-Beinier, G. Mai, J. F. Lambert, R. J. Fish, G. Pernod, L. Buehler, H. Bounameaux, and E. K. Kruithof. Characterization of endothelial-like cells derived from human mesenchymal stem cells. $J$ Thromb Haemost, 5(4):826-34, 2007.

[31] J. Doorn, G. Moll, K. Le Blanc, C. van Blitterswijk, and J. de Boer. Therapeutic applications of mesenchymal stromal cells: paracrine effects and potential improvements. Tissue Eng Part B Rev, 18(2):101-15, 2012.

[32] T. R. Cox and J. T. Erler. Remodeling and homeostasis of the extracellular matrix: implications for fibrotic diseases and cancer. Dis Model Mech, 4(2):16578, 2011.

[33] R. J. Gillies, I. Robey, and R. A. Gatenby. Causes and consequences of increased glucose metabolism of cancers. J Nucl Med, 49 Suppl 2:24S-42S, 2008.

[34] S. Ravi and E. L. Chaikof. Biomaterials for vascular tissue engineering. Regen Med, 5(1):107-20, 2010.

[35] L. Tian and S. C. George. Biomaterials to prevascularize engineered tissues. J Cardiovasc Transl Res, 4(5):685-98, 2011.

[36] J. Rouwkema, N. C. Rivron, N. M. S. Bettahalli, D. Stamatialis, M. Wessling, and C. A. van Blitterswijk. Mesenchymal stem cells differentiate towards endothelial cells in a prevascularized bone tissue engineering setting. Tissue Eng Part A, 01 2008. 


\title{
Chapter 7
}

\section{Human mesenchymal stromal cells as single cell source for both bone and vessel engineering}

Karolina Janeczek Portalska, Eelco Fennema, Henk Garritsen, Auke Renard, Clemens van Blitterswijk and Jan de Boer

\begin{abstract}
Current bone tissue engineering approaches need further optimization on the amount of bone deposited by the grafted osteoprogenitors and the rate at which the graft is vascularised. We have recently described a modular bone tissue engineering system, comprising spheroids of human mesenchymal stromal cells (hMSCs), calcium phosphate microparticles and in-situ-setting autologous fibrin thrombin gel as carrier. Its modular nature allowed optimization of critical parameters such as material properties, handling and culture conditions. In this manuscript, we investigate the possibility to use MSCs as the single source for both bone and endothelial engineering, in order to create a more physiological bone graft and improve vascularization. To this end, we differentiated hMSCs towards endothelial-like cells. Here we combine these developments and demonstrate that endothelial-like cells can improve the bone forming capacity of hMSCs. We also discuss possible explanations for observed improvements and propose further system modifications that could lead to development of clinically relevant bone grafts.
\end{abstract}

\subsection{Introduction}

Even though bone has amazing self-healing capacity, in several cases such as large defects, non-unions or tumor-resections, the healing capabilities of bone is not sufficient 1]. In addition, osteoporosis is an epidemic disorder that increases with advanc- 
ing age. In these patients fractures often occur in which compression of the cancellous bone causes a defect that has to be filled with bone or bone substitutes.

The current golden standard for treatment of bone defects is harvesting of autologous bone from the patient's body (e.g. the iliac crest) and transplantation into the defect. There are no issues with immune-rejection or pathogen-transfer, but the downside is the limited availability of bone, additional pain caused by second wound and risk of infection during acquisition [2]. Several other strategies for bone defect grafting have been developed and are currently used in the clinic, each with their own advantages and limitations. Allogeneic bone grafting can result in satisfactory but limited outcome compared to autografting, since allografts are devitalized to avoid an immunological response from the host. Such grafts are also associated with risk of transmitting diseases. In case of synthetic grafts, two major problems typically occurring are unsatisfactory mechanical strength (e.g. in the case of calcium phosphate ceramics) or poor integration with surrounding tissue (e.g. metal grafts) [3]. Furthermore, metal implants are not biodegradable and thus do not allow full tissue regeneration.

Due to unsatisfactory results of bone replacement with artificial materials another approach based on tissue engineering principles was suggested and developed [4]. The concept of combining scaffolds materials with cells that will deposit new bone tissue and allow for good integration with surrounding tissue was widely investigated and was shown to offer excellent results in numerous animal models [5 7], including critical sized defects. Several clinical trials on humans have been performed with such various outcomes 4, 8, demonstrating that standardization and improvement of existing protocols is crucial. Several issues need to be addressed to achieve this, including the type and number of used cells, culture conditions and applied material.

Cells used in bone tissue engineering (BTE) can be isolated from several sources, each associated with specific advantages and drawbacks. Various types of both mature cell types including osteoblasts and osteoprogenitor cells together with several types of stem cells, including embryonic stem cells, induced pluripotent stem cells and adult stem cells were investigated as potential source for BTE. Due to problems with acquisition of relevant number of osteoblast and osteoprogenitor cells [9] and the teratoma formation associated with the use of embryonic and pluripotent stem cells [10], adult stem cells are currently one of the most interesting cell types for BTE applications.

Mesenchymal stromal cells (MSC), often referred to as mesenchymal stem cells, were first described by Friedenstein et al. 11], and are adult stromal cells that can be isolated from various tissues including bone marrow, adipose tissue, trabecular bone, placenta, periosteum, dental pulp and femur 12 15. They have an excellent proliferation capacity and were shown to be able to differentiate among others into osteogenic, adipogenic, chondrogenic, muscle and endothelial lineages 16$] 19]$. It is relatively easy to obtain sufficient quantities of MSCs from adults and by that, they can be used as an autologous source of therapeutic cells. Several studies were performed to optimize MSC performance in bone tissue engineering including solving 
the problems with donor variation 20 and necessity of in vitro expansion 21. Still, the main issue is the total amount of newly deposited bone in vivo, where human cells do not perform as well as previously investigated animal-derived MSCs. Therefore, many strategies aim at further improving the efficiency of BTE. Changes in the culture conditions of MSCs in vitro were applied, including 3D culture and culture in bioreactors 22, pre-differentiation towards osteogenic lineages 23 and combining these cells with various scaffold materials [24].

We have recently developed a system that allows for efficient and reproducible bone formation 21. It consists of aggregated hMSCs combined with calcium phosphate micro particles 21], and contains an in-situ-setting autologous fibrin thrombin gel as carrier. In house, we refer to it as the micro-aggregate system. The system requires little time to generate, since there is no need for in vitro culture and additionally, all components used are clinically approved. Furthermore, since the delivery can be optimized to be injectable, the method is minimally invasive to the patient.

Rouwkema et al. 25] demonstrated that a trophic effect of endothelial cells can improve the bone forming capacity of hMSCs. To further improve our system without the necessity of applying clinically irrelevant cells, we decided to combine it with yet another relevant cell type: endothelial-like MSCs (EL-MSC). These cells can easily be obtained from hMSCs [19] from all tested donors [26] and were shown to possess several endothelial characteristics. The use of a single source of progenitor cells reduces the complexity of the system and allows for easier clinical implementation. It also allows to obtain cells for therapy during one single surgery.

This work presents the beneficial influence of EL-MSCs on the amount of engineered bone and discusses the possible explanation for the observed improvement.

\subsection{Materials and methods}

\subsubsection{Isolation and culture}

Human mesenchymal stromal cells (hMSCs) were isolated from human bone marrow from donors with written informed consent 27 . Aspirates were resuspended using a $20 \mathrm{G}$ needle and plated at a density of 0.5 million mono-nucleated cells per $\mathrm{cm}^{2}$. Cells were grown in MSC proliferation medium which contains minimal essential medium (alfa-MEM, GIBCO) supplemented with $10 \%$ fetal bovine serum (FBS, Lonza), $100 \mathrm{U} / \mathrm{ml}$ penicillin (GIBCO), $10 \mu \mathrm{g} / \mathrm{ml}$ streptomycin (GIBCO), $2 \mathrm{mM} \mathrm{L-}$ glutamin (GIBCO), $0.2 \mathrm{mM} \mathrm{L}$-ascorbic acid 2-phosphate magnesium salt (ASAp, Sigma-Aldrich) and $1 \mathrm{ng} / \mathrm{ml}$ basic fibroblast growth factor (bFGF, Fisher Scientific) at $37^{\circ} \mathrm{C}$ in a humid atmosphere with $5 \% \mathrm{CO}_{2}$. hMSCs used in this study have been characterized previously (unpublished data) according to the set of standards proposed by the Mesenchymal and Tissue Stem Cell Committee of the International Society for Cellular Therapy [28]. We also have data concerning the osteogenic differentiation of these cells which allows us to select donors with varying bone-forming potential for further study. Here we used MSCs that were shown before to express 
osteogenic markers upon differentiation and form bone in vivo (unpublished data). Cells were expanded up to passage 2. For further experiments hMSCs were cultured in basic medium (alfa-MEM supplemented with 10\% FBS, $100 \mathrm{U} / \mathrm{ml}$ penicillin, 10 $\mu \mathrm{g} / \mathrm{ml}$ streptomycin, $2 \mathrm{mM}$ L-glutamin and $0.2 \mathrm{mM}$ ASAp).

\subsubsection{Endothelial induction of MSCs}

hMSCs from passage 2 were used for endothelial induction as described previously [19]. Briefly, cells were seeded at a density of 3,000 cells $/ \mathrm{cm}^{2}$ on tissue culture plastic in endothelial growth medium (EGM-2, Lonza) and cultured for 10 days. After one day in static culture, shear force was applied using an orbital shaker at a rate of $20 \mathrm{rpm}$. Cells that were cultured according to this protocol will be referred to as EL-MSCs.

\subsubsection{Capillary-like structures formation on Matrigel}

Wells of 6 -well plates were covered with $1 \mathrm{ml}$ of growth factor reduced Matrigel (BD Bioscience) diluted 1:1 in EGM-2 without growth factors. Cells were seeded at a density of 30,000 cells $/ \mathrm{cm}^{2}$ and cultured in a humid atmosphere with $5 \% \mathrm{CO}_{2}$ for 24 hours. The formation of capillary-like structures (CLS) was observed after 24 hours using an inverted microscope (Nikon Eclipse TE300). Pictures were taken using a Nikon DS-L2 camera.

\subsubsection{RNA isolation and quantitative PCR}

Total RNA was isolated using TRIZOL reagent according to the manufacturer's protocol. Briefly, $1 \mathrm{ml}$ of Trizol reagent was added per T25 flask (cells cultured in basic medium) or per well (cells cultured on Matrigel in 6-well plates and cells cultured in micro-aggregate system). Samples were incubated for $5 \mathrm{~min}$ at room temperature to allow complete dissociation. Phase separation was performed by adding chloroform, and then samples were shaken vigorously for 15 seconds and incubated for 3 min at room temperature. After that samples were centrifuged at 12,000 x g for $15 \mathrm{~min}$. RNA was precipitated by mixing the aqueous phase with isopropyl alcohol followed by 10 min incubation at room temperature. Samples were centrifuged again and the remaining RNA pellet was washed with $75 \%$ ethanol. The obtained samples were dissolved in water. The quantity and quality of RNA was analyzed using spectrophotometry (ND-1000 spectrophotometer).

For first strand cDNA synthesis, $500 \mathrm{ng}$ of RNA was used in combination with Superscript II (Invitrogen) according to the manufacturer's protocol. One $\mu \mathrm{l}$ of $3 \mathrm{x}$ diluted cDNA was used for further gene amplification. PCR was performed in real time PCR machine (BioRad). Data was analyzed using Bio-Rad iQ5 software. Expression of endothelial genes was calculated relative to major histocompatibility complex (B2M) levels by the comparative $\Delta \mathrm{CT}$ method. Primers used in the study are listed in Table 7.1 . 


\begin{tabular}{|l|l|}
\hline $\begin{array}{l}\text { CD31 (Platelet Endothelial } \\
\text { Cell Adhesion Molecule-1) }\end{array}$ & $\begin{array}{l}\text { F 5' TCTATGACCTCGCCCTCCACAAA 3' } \\
\text { R 5' GAACGGTGTCTTCAGGTTGGTATTTCA 3' }\end{array}$ \\
\hline $\begin{array}{l}\text { VEGF (Vascular Endothelial } \\
\text { Growth Factor) }\end{array}$ & Commercially bought from SA Biosciences \\
\hline ALP (alkaline phosphatase) & $\begin{array}{l}\text { F 5' GACCCTTGACCCCCACAAT 3' } \\
\text { R 5' GCTCGTACTGCATGTCCCCT 3' }\end{array}$ \\
\hline $\begin{array}{l}\text { BMP2 (bone morphogenetic } \\
\text { protein 2) }\end{array}$ & Commercially bought from SA Biosciences \\
\hline BSP (bone sialoprotein) & $\begin{array}{l}\text { F 5' TGCCTTGAGCCTGCCTGCTTCC 3' } \\
\text { R 5' CAAAATTAAAGCAGTCTTCATT 3' }\end{array}$ \\
\hline OP (osteopontin) & $\begin{array}{l}\text { F 5' CCAAGTAAGTCCAACGAAAG 3' } \\
\text { R 5' GGTGATGTCCTCGTCTGTA 3' }\end{array}$ \\
\hline OC (osteocalcin) & F 5' GGCAGCGAGGTAGTGAAGAG 3' \\
& R 5' GATGTGGTCAGCCAACTCGT 3' \\
\hline B2M & F 5' GACTTGTCTTTCAGCAAGGA 3' \\
R 5' ACAAAGTCACATGGTTCACA 3'
\end{tabular}

Table 7.1: Primers used for qPCR.

\subsubsection{Generation of cell aggregates}

Microwells in agarose chips were prepared as described previously 21, 29, 30]. Briefly, PDMS (poly-dimethylsiloxane) stamps (each to prepare 1400 wells of $400 \mu \mathrm{m}$ in diameter and $200 \mu \mathrm{m}$ in depth) were disinfected in $70 \%$ ethanol, placed in the wells of 6 -well plates and covered with $3 \%$ agarose (Ultra-pure agarose, Invitrogen). Upon solidification, the agarose chips were placed in 12-well plates and wetted with culture medium. $1 \mathrm{ml}$ of cell suspension containing 1.5 million hMSCs was uniformly dispersed over the wells on each chip. The chips were then shortly centrifuged at $1500 \mathrm{rpm}$ to facilitate settling down of the cells. Cell aggregates spontaneously formed within the following 24 hours of culture in basic medium.

\subsubsection{Platelet gel acquisition and preparation}

Platelet gel was obtained and prepared as described before 21]. Briefly, a standard thrombocyte apheresis procedure using a Terumo BCT Spectra/Trima apheresis unit was performed on healthy donors with written consent (Institute für Klinische Transfusionsmedizin, Braunschweig, Germany). Samples were stored at $-80^{\circ} \mathrm{C}$. At the time of the experiment, samples were heated to $37^{\circ} \mathrm{C}$ to lyse the cryopreserved platelets, release growth factors and form platelet lysate. $235 \mu \mathrm{l}$ of $1 \mathrm{M}$ calcium chloride was added per $10 \mathrm{ml}$ of platelet lysate and mixed at $37^{\circ} \mathrm{C}$ for 10 minutes. As a result, the lysate separated into gel containing fibrin and liquid containing thrombin. To solidify the gel, remaining platelet lysate was mixed again with thrombin (at 1:1 ratio) which activated the clotting pathway and resulted in platelet gel formation. 


\subsubsection{Generation of the micro-aggregate system}

Biphasic calcium phosphate (BSP) ceramic particles (average size of 53-63 $\mu \mathrm{m}$ ) were produced as described before [31]. $20 \mu \mathrm{g}$ of ceramic micro particles were put within each $10 \mathrm{ml}$ tube. The cell aggregates were gently flushed from the agarose chips with basic medium and transferred to the tubes. Emptied chips were then examined for the possibility of remaining aggregates and in such a case flushed again to provide equal number of aggregates per sample. This procedure did not result in any changes in the shape or size of the aggregates 21. Next, $10 \%$ or $50 \%$ ( 0.15 or 0.75 million) of hMSCs or EL-MSCs in suspension were added to each tube. The $10 \mathrm{ml}$ tubes containing micro particles, cell aggregates and cells in suspension were gently centrifuged and the supernatant was removed. After that, $300 \mu \mathrm{l}$ of the prepared thrombin was added to each tube followed by the addition of $300 \mu \mathrm{l}$ of platelet lysate. The content of the tube was then gently mixed and pipetted into a well of a non-tissue culture treated, 12-well plate. Resulting constructs were then maintained in culture in microaggregate medium (DMEM (GIBCO) supplemented with $100 \mathrm{U} / \mathrm{ml}$ penicillin, 10 $\mu \mathrm{g} / \mathrm{ml}$ streptomycin, $0.2 \mathrm{mM}$ ASAp, ITS, proline, $100 \mathrm{mM} 11 \mathrm{mg} / \mathrm{ml}$ sodium pyruvate and dexamethasone) or EGM-2 medium at $37^{\circ} \mathrm{C}$ for one week (in vitro study) or proceeded to implantation after first 24 hours in culture in micro-aggregate medium.

\subsubsection{Construct implantation and histochemical analysis}

Male 6-week old NMRI-nu mice (Harlan) were anesthetized with a mixture of isofluorane and oxygen after which constructs were implanted in four subcutaneous pockets $(\mathrm{n}=10)$. Ceramic particles with 1.5 million of hMSCs in aggregates and $10 \% \mathrm{hMSC}$ addition in suspension, ceramic particles with 1.5 million of hMSCs in aggregates and $10 \%$ EL-MSC addition in suspension, ceramic particles with 1.5 million of hMSCs in aggregates and 50\% MSC addition in suspension and ceramic particles with 1.5 million of hMSCs in aggregates and 50\% EL-MSC addition in suspension were implanted. Six weeks after implantation $(n=7$, due to sample loss caused by exposure to air), the mice were sacrificed and implants were recovered. Samples were fixed in $10 \%$ formalin, embedded in methacrylate and sectioned at $300 \mu \mathrm{m}$ on a histological diamond saw (Leica saw microtome cutting system). A minimum of 6 sections were made from each sample. Sections were stained with basic Fuchsin and methylene blue to visualize bone formation. Quantitative histomorphometry was performed on the middle (4th) section of each sample of which high resolution digital pictures were obtained. Whole sample area and bone areas were semi-automatically selected based on color hue in GIMP 2 software (Select by Color Tool: Selects regions with similar colors) and percentage of bone area per sample was calculated.

\subsubsection{Statistics}

Each experiment was performed in triplicate. Data which required multiple comparison tests was analysed in SPSS (PASW statistics) using one-way Anova followed by Tukey's multiple comparison test $(\mathrm{P}<0.05)$. In case where comparisons between two groups were made, a Student's paired t-test was performed. 


\subsubsection{Ethics statement}

Human mesenchymal stromal cells (hMSCs) were isolated from human bone marrow from donors with written informed consent. This study was carried out in strict accordance with the recommendations of Medisch Ethische ToetsingsCommissie Twente (Medical Ethical Research Committee Twente) and was approved by this Committee.

The animal study reported on in this manuscript was ethically assessed a priori by animal ethics committee 2010-III-10-125 DEC-Utrecht as required by Dutch law. Animals were housed at the Central Laboratory Animal facility (Utrecht University, Utrecht, The Netherlands), and experiments were approved by the local animal care and user committee Dierexperimentencommissie Academisch Biomedisch Centrum (DEC-ABC). All surgery was performed under isofluorane/oxygen anesthesia, and all efforts were made to minimize suffering. Animals were fed ad libitum.

\subsection{Results and Discussion}

\subsubsection{Endothelial nature of EL-MSCs}

To confirm the endothelial nature of differentiated hMSCs from donor 240, a Matrigel assay was performed and their gene expression profile was assessed. As described previously 19, 26], differentiated hMSCs formed capillary-like structures on Matrigel (Figure 7.1A). EL-MSCs obtained from the analyzed donor, after 24 hour culture on Matrigel, also expressed the endothelial marker CD31 Figure 7.1B). These results demonstrated that the hMSCs isolated from donor 240 acquired endothelial characteristics, both phenotypical and functional. Based on our previous results (unpublished data) we can expect that donor 240-derived EL-MSCs, when implanted, would be able to attract in-growing host vessel and also contribute to their walls.

\subsubsection{Micro-aggregate system preparation}

Ceramic particles, cell spheroids, single cells and platelet gel were mixed together to generate tissue engineered constructs. The cells and scaffolds were rapidly encapsulated within the fibrin thrombin components of platelet gel (Figure 7.2A). Resulting constructs were cultured for 24 hours in micro-aggregate medium (for in vivo study) or one week in micro-aggregate or EGM-2 medium (for in vitro study). Already after 24 hours of culture the samples shrank significantly, but after that their shape did not change for one week (Figure 7.2 A). Due to the presence of ceramic particles in the construct we were not able to observe whether MSCs or EL-MSCs formed capillarylike structures within the sample. Upon histological evaluation of the explants after 6 weeks large area of newly formed bone can be seen in which we observed osteocytes embedded in a mineralized extracellular matrix (Figure $7.2 \mathrm{~B}$ ). The presence of bone marrow areas indicated functional bone. 


\section{A}
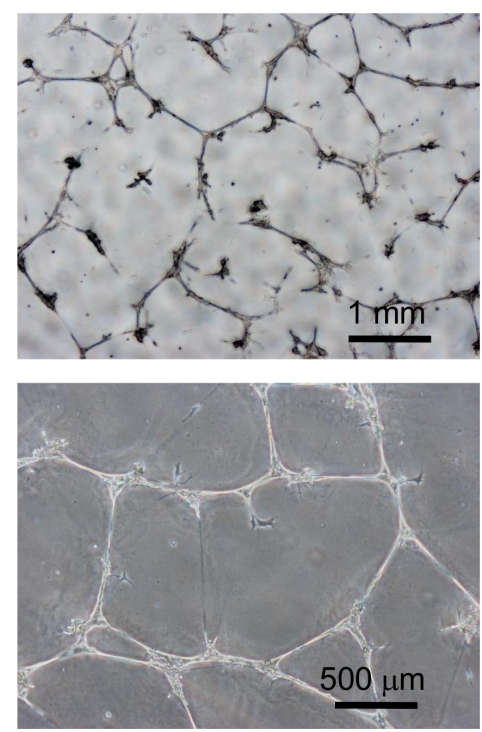

B

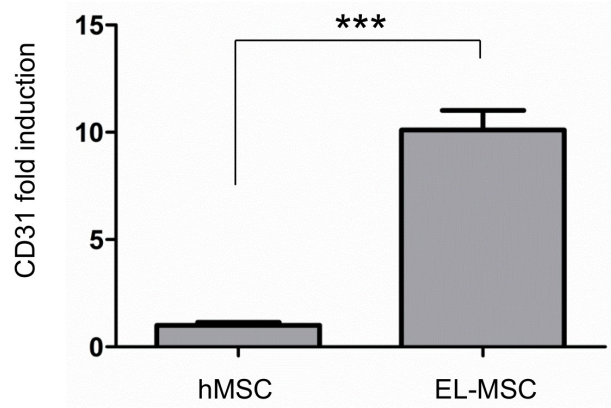

Figure 7.1: EL-MSC characterization. Matrigel assay with EL-MSCs (A). CD31 expression in MSCs and EL-MSCs obtained from donor 240 (B). *** denotes statistical significance $(\mathrm{P}<0.001)$.

\subsubsection{Effect of EL-MSCs on in vivo bone formation}

To observe the influence of introduction of single-cell suspension on the amount of obtained bone, four conditions were analyzed, each including ceramic particles with 1.5 million hMSCs in aggregates combined with 10\% hMSCs, $10 \%$ EL-MSCs, $50 \%$ hMSCs or $50 \%$ EL-MSCs added in suspension. The $10 \%$ hMSC group was used as benchmark. Histochemical analyses were performed on the explants after 6 weeks in vivo. Staining with basic Fuchsin revealed the presence of newly formed bone 


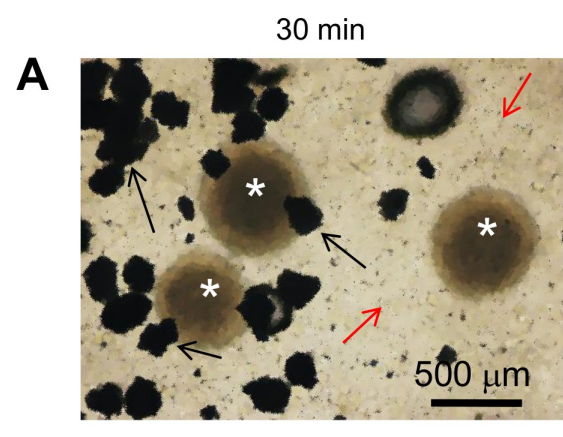

24 hours

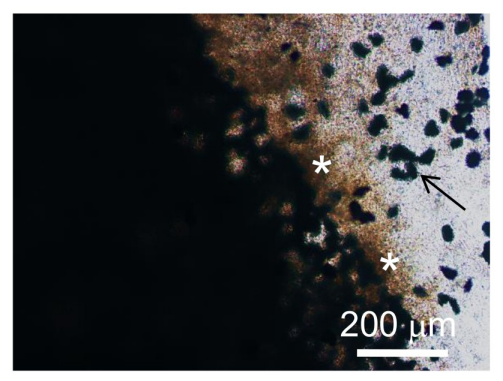

1 week

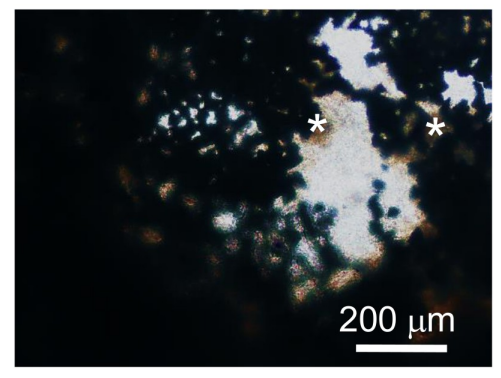

B

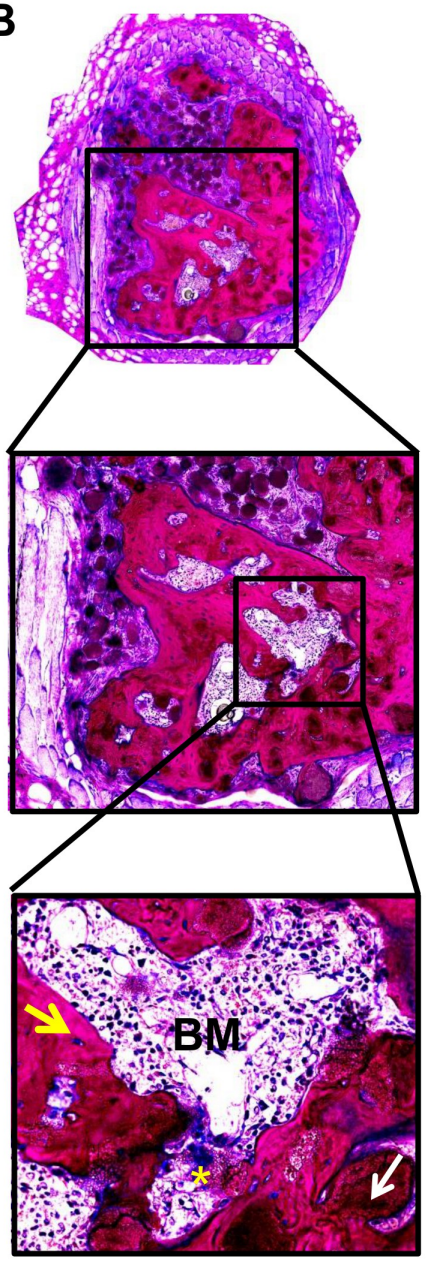

Figure 7.2: Micro-aggregate system $30 \mathrm{~min}, 24$ hours and 1 week after assembly. Cell aggregates $(*)$, ceramic particles (black arrow) and cells in suspension (red arrow) can be observed (A). Bone formation within microaggregate system in vivo. Methylen blue and basic Fuchsin stained section shows large areas of mature bone (dark pink), ostyocytes embedded in matrix (yellow arrow) and scaffold (white arrow). Six weeks after implantation hardly any osteoid (unmineralized matrix indicated by yellow star) can be seen.

within the samples (Figure 7.3A). Quantitative histomorphometry showed differences between samples with MSCs and EL-MSCs (Figure 7.3B). Due to the limited number of samples per condition, the performed Anova analysis did not detect any significant differences in the amount of bone detected in these samples. However, when we looked 
at the individual samples within each mouse separately, in all but one case, addition of $10 \%$ EL-MSCs led to a higher bone area in the sample as compared to addition of $10 \%$ hMSCs (Figure $7.3 \mathrm{C}$ ). In case of $50 \%$ EL-MSC addition the same was true in all but two cases. Addition of $50 \%$ hMSCs seemed to have random effect on the bone area when compared to $10 \%$ hMSCs (more bone in 4 cases, less bone in 3 ). Based on our previous results 32 we can thus conclude, that the increased bone formation in the samples with $50 \%$ more cells was simply due to the increased number of cells in the construct. We showed this effect with MSCs 32 and we assume that the same happened with the addition of EL-MSCs. Contrary to this, the effect caused by the presence of $10 \%$ additional EL-MSCs was likely not only due to the increased cell number, since the increased amount of bone was not observed in reference conditions (10\% MSCs addition). Therefore we decided to look for another explanation behind EL-MSCs' influence on bone formation in implanted constructs.

\subsubsection{Osteogenic and endothelial gene expression in micro-aggregate system}

To determine whether addition of EL-MSCs to the system has any effect on the expression of the osteogenic genes, we performed qPCR using a panel of commonly used osteogenic genes on two types of constructs (with $10 \%$ hMSC or $10 \%$ EL-MSC addition) after 1 week of in vitro culture. The panel of osteogenic genes included alkaline phosphatase (ALP), bone morphogenetic protein 2 (BMP2), bone sialoprotein (BSP), osteopontin (OP) and osteocalcin (OC). We used two types of medium (micro-aggregate medium and EGM-2) to eliminate the risk that the potential ELMSC influence would be obscured by strong osteogenic influence of the components of micro-aggregate medium. Neither in micro-aggregate nor in EGM-2 medium did we find any significant changes in osteogenic marker expression (Figure 7.4 A) though the absolute value is higher in the samples with the addition of EL-MSCs. Our results clearly showed that introduction of EL-MSCs in the micro-aggregate system did not influence osteogenic marker expression when compared to the introduction of hMSCs. Interestingly, there were also no significant differences between these marker expressions when comparing the two culture media which were used. This indicated that the osteogenic influence of the system itself (BCP ceramic particles combined with platelet gel) was independent of the applied medium. Additionally, these results indicate that the EL-MSCs did not cause the increased bone formation in micro-aggregates by enhancing the expression of osteogenic genes in MSCs.

Another possibility is that EL-MSCs implanted in micro-aggregate system improved the vascularization of the constructs and by that assured better oxygen and nutrients supply. EL-MSCs could cause such effect in two ways, by expressing proangiogenic factors and attracting the in-growth of host blood vessels or by directly contributing to the vascular network, as demonstrated previously $19,33,34$. In order to determine which of the situations occurred, we have tested whether addition of EL-MSCs to the system has any effect on the expression of the endothelial and pro-angiogenic marker genes. We performed qPCR for human CD31 as a marker of 


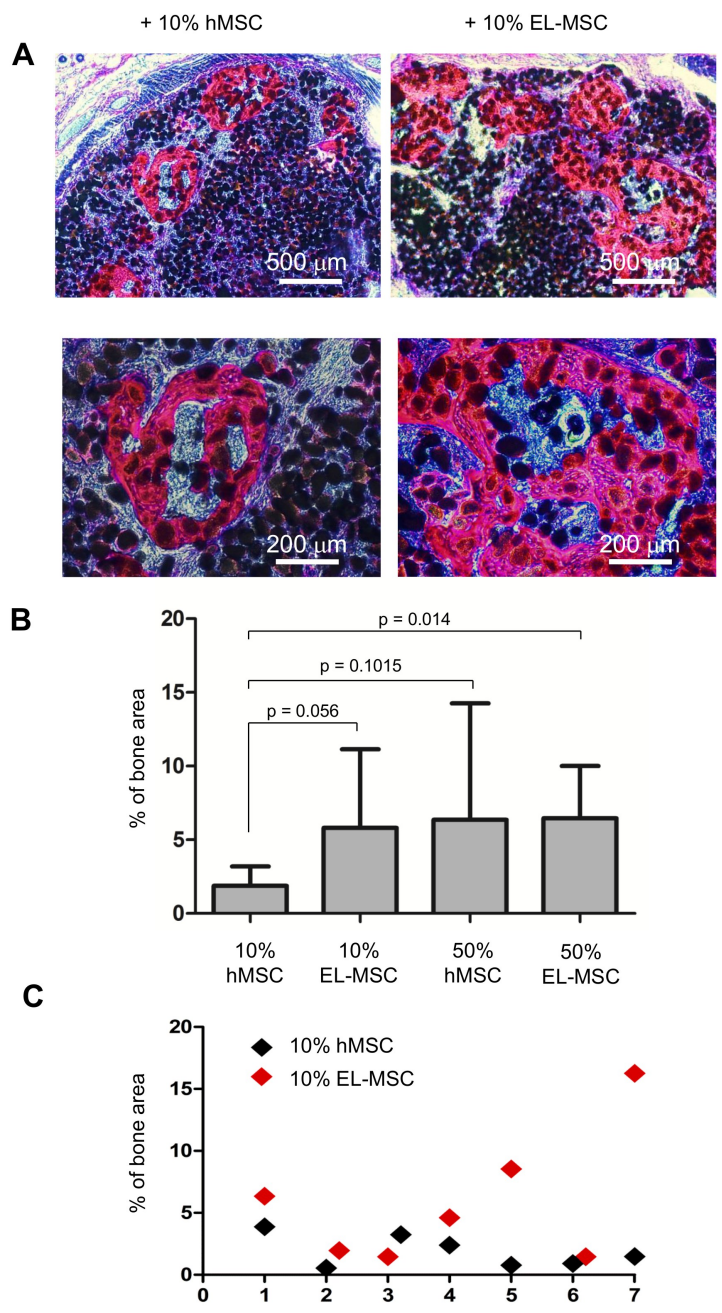

Figure 7.3: In vivo bone formation on porous ceramic scaffolds. Representative histological section of tissue engineered constructs (A). Newly formed bone (dark pink), and ceramic particles (black) can be distinguished. Bar graph comparing the amount of bone formed per scaffold area within samples seeded with $10 \%$ or $50 \%$ addition of MSCs or EL-MSCs (B). Graph comparing the amount of bone formed per scaffold area within samples seeded with $10 \%$ addition of MSCs or EL-MSCs, grouped per mouse, $n=7$ (C). Error bars represent standard deviation.

endothelial cells and for VEGF to check for a possible trophic effect. Similar to the osteogenic genes, two types of constructs (with $10 \%$ hMSC or $10 \%$ EL-MSC addition) after 1 week of in vitro culture were used in this study. Neither in micro-aggregate 
A

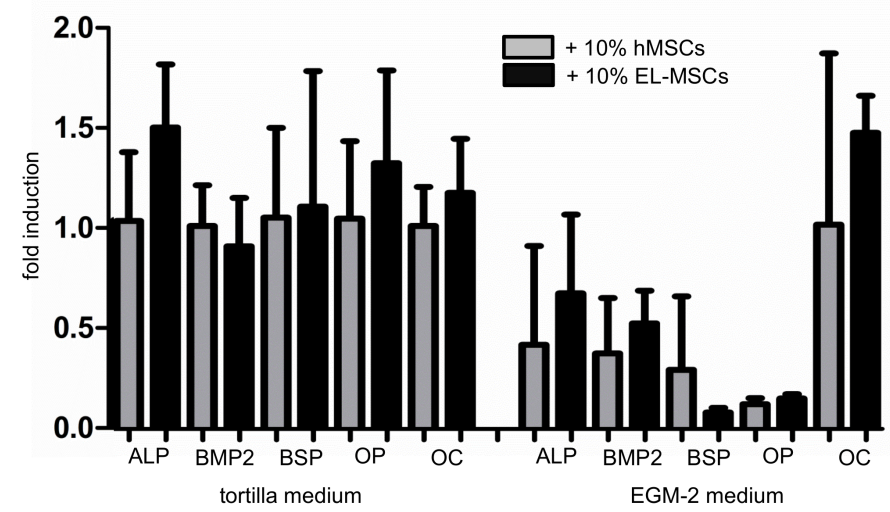

B

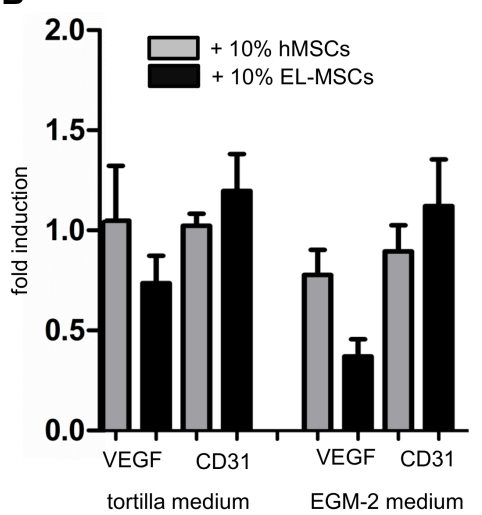

Figure 7.4: Osteogenic (A) and endothelial (B) gene expression in micro-aggregate system. The expression of alkaline phosphatase (ALP), bone morphogenetic protein 2 (BMP2), bone sialoprotein (BSP), osteopontin (OP), osteocalcin (OC), CD31 and VEGF was assessed after 7 days of in vitro culture in micro-aggregate or EGM-2 medium.

nor in EGM-2 medium did we find any significant changes in CD31 or VEGF expression (Figure 7.4B). Since we know that EL-MSCs express more CD31 as compared to MSCs, the lack of significant differences in CD31 expression in two tested conditions is probably caused by the abundance of MSCs in the micro-aggregate system. Possible mechanisms in which EL-MSCs can contribute to bone formation are discussed next. First, both the pro-angiogenic and the vasculogenic influence of EL-MSCs can be too subtle to be detected in vitro, whereas in vivo it can be enough to improve bone formation. Moreover, EL-MSCs present in the sample could influence not only the cells implanted in the micro-aggregate system but also host cells. To confirm such possibility, additional studies are required that will check for osteogenic gene expression 
within the implanted samples and their surroundings and not only within constructs cultured in vitro. Furthermore, we have tested for only one pro-angiogenic growth factor, namely VEGF. Since we did not find any increase in VEGF expression as compared to control samples, it is therefore likely, that the trophic effect of EL-MSCs is enforced via other growth factors. There is also a possibility that the quantified expression level of VEGF does not reflect the actual amount of released VEGF since it depends strongly on various post-translational control mechanisms [35. Finally, we have tested the expression levels at one time point only, whereas the beneficial effect of EL-MSC in tested constructs could be related to speeding up of the expression of osteogenic or pro-angiogenic genes at earlier or later time points.

\subsection{Conclusions}

We have confirmed the ability of MSCs to differentiate into endothelial-like cells. We have also shown that the addition of single cells to the previously developed boneforming system based on platelet gel, cell spheroids and ceramic micro particles, did not negatively affect the bone-forming capacity of this system. The most important result presented in this study is that a relatively small (10\%) addition of EL-MSCs in the bone forming system increased the amount of obtained bone in all but one case. We tested for two possible explanations of this phenomenon. Unfortunately, we did not find any influence of EL-MSCs on the osteogenic or endothelial gene expression in the micro-aggregate system in vitro. Still, the possibility that this is the mechanism of their influence cannot be excluded, since we have tested the expression of these genes at one time point only, moreover, the expression levels in vitro might not reflect the levels in vivo. 


\subsection{Bibliography}

[1] A. J. Salgado, O. P. Coutinho, and R. L. Reis. Bone tissue engineering: state of the art and future trends. Macromol Biosci, 4(8):743-65, 2004.

[2] C. J. Damien and J. R. Parsons. Bone graft and bone graft substitutes: a review of current technology and applications. J Appl Biomater, 2(3):187-208, 1991.

[3] William R. Moore, Stephen E. Graves, and Gregory I. Bain. Synthetic bone graft substitutes. ANZ Journal of Surgery, 71(6):354-361, 2001.

[4] G. J. Meijer, J. D. de Bruijn, R. Koole, and C. A. van Blitterswijk. Cell-based bone tissue engineering. PLoS Med, 4(2):e9, 2007.

[5] J. Goshima, V. M. Goldberg, and A. I. Caplan. The osteogenic potential of culture-expanded rat marrow mesenchymal cells assayed in vivo in calcium phosphate ceramic blocks. Clin Orthop Relat Res, 262:298-311, 1991.

[6] S. P. Bruder, K. H. Kraus, V. M. Goldberg, and S. Kadiyala. The effect of implants loaded with autologous mesenchymal stem cells on the healing of canine segmental bone defects. J Bone Joint Surg Am, 80(7):985-96, 1998.

[7] H. Petite, V. Viateau, W. Bensaid, A. Meunier, C. de Pollak, M. Bourguignon, K. Oudina, L. Sedel, and G. Guillemin. Tissue-engineered bone regeneration. Nat Biotechnol, 18(9):959-63, 2000.

[8] R. Quarto, M. Mastrogiacomo, R. Cancedda, S. M. Kutepov, V. Mukhachev, A. Lavroukov, E. Kon, and M. Marcacci. Repair of large bone defects with the use of autologous bone marrow stromal cells. $N$ Engl $J$ Med, 344(5):385-6, 2001.

[9] Saburo Nishida, Naoto Endo, Hiroshi Yamagiwa, Tatsuhiko Tanizawa, and Hideaki E. Takahashi. Number of osteoprogenitor cells in human bone marrow markedly decreases after skeletal maturation. Journal of Bone and Mineral Metabolism, 17(3):171-177, 1999.

[10] J. M. Jukes, L. Moroni, C. A. van Blitterswijk, and J. de Boer. Critical steps toward a tissue-engineered cartilage implant using embryonic stem cells. Tissue Eng Part A, 14(1):135-47, 2008.

[11] A. J. Friedenstein, R. K. Chailakhyan, N. V. Latsinik, A. F. Panasyuk, and I. V. Keiliss-Borok. Stromal cells responsible for transferring the microenvironment of the hemopoietic tissues. cloning in vitro and retransplantation in vivo. Transplantation, 17(4):331-40, 1974.

[12] C. M. Cowan, Y. Y. Shi, O. O. Aalami, Y. F. Chou, C. Mari, R. Thomas, N. Quarto, C. H. Contag, B. Wu, and M. T. Longaker. Adipose-derived adult stromal cells heal critical-size mouse calvarial defects. Nat Biotechnol, 22(5):560$7,2004$. 
[13] R. O. Oreffo, A. Bennett, A. J. Carr, and J. T. Triffitt. Patients with primary osteoarthritis show no change with ageing in the number of osteogenic precursors. Scand J Rheumatol, 27(6):415-24, 1998.

[14] Z. Miao, J. Jin, L. Chen, J. Zhu, W. Huang, J. Zhao, H. Qian, and X. Zhang. Isolation of mesenchymal stem cells from human placenta: comparison with human bone marrow mesenchymal stem cells. Cell Biol Int, 30(9):681-7, 2006.

[15] Y. C. Chai, S. J. Roberts, E. Desmet, G. Kerckhofs, N. van Gastel, L. Geris, G. Carmeliet, J. Schrooten, and F. P. Luyten. Mechanisms of ectopic bone formation by human osteoprogenitor cells on cap biomaterial carriers. Biomaterials, 33(11):3127-42, 2012.

[16] P. Bianco and P. Gehron Robey. Marrow stromal stem cells. J Clin Invest, 105(12):1663-8, 2000.

[17] M. Dezawa, H. Ishikawa, Y. Itokazu, T. Yoshihara, M. Hoshino, S. Takeda, C. Ide, and Y. Nabeshima. Bone marrow stromal cells generate muscle cells and repair muscle degeneration. Science, 309(5732):314-7, 2005.

[18] X. Jiang, H. Q. Cao, L. Y. Shi, S. Y. Ng, L. W. Stanton, and S. Y. Chew. Nanofiber topography and sustained biochemical signaling enhance human mesenchymal stem cell neural commitment. Acta Biomater, 2011.

[19] K. Janeczek Portalska, A. Leferink, N. Groen, H. Fernandes, L. Moroni, C. van Blitterswijk, and J. de Boer. Endothelial differentiation of mesenchymal stromal cells. PLoS One, 7(10):e46842, 2012.

[20] R. Siddappa, R. Licht, C. van Blitterswijk, and J. de Boer. Donor variation and loss of multipotency during in vitro expansion of human mesenchymal stem cells for bone tissue engineering. J Orthop Res, 25(8):1029-41, 2007.

[21] A. Chatterjea, H. Yuan, S. Chatterjea, H. Garritsen, A. Renard, C. A. van Blitterswijk, and J. de Boer. Engineering new bone via a minimally invasive route using human bone marrow-derived stromal cell aggregates, microceramic particles, and human platelet-rich plasma gel. Tissue Eng Part A, 19(3-4):340-9, 2013.

[22] S. Kale, S. Biermann, C. Edwards, C. Tarnowski, M. Morris, and M. W. Long. Three-dimensional cellular development is essential for ex vivo formation of human bone. Nat Biotechnol, 18(9):954-8, 2000.

[23] J. Doorn, J. van de Peppel, J. P. van Leeuwen, N. Groen, C. A. van Blitterswijk, and J. de Boer. Pro-osteogenic trophic effects by pka activation in human mesenchymal stromal cells. Biomaterials, 32(26):6089-98, 2011.

[24] K. J. Burg, S. Porter, and J. F. Kellam. Biomaterial developments for bone tissue engineering. Biomaterials, 21(23):2347-59, 2000. 
[25] J. Rouwkema, P. E. Westerweel, J. de Boer, M. C. Verhaar, and C. A. van Blitterswijk. The use of endothelial progenitor cells for prevascularized bone tissue engineering. Tissue Eng Part A, 15(8):2015-27, 2009.

[26] K. Janeczek Portalska, N. Groen, G. Krenning, N. Georgi, A. Mentink, M. C. Harmsen, C. van Blitterswijk, and J. de Boer. The effect of donor variation and senescence on endothelial differentiation of human mesenchymal stromal cells. Tissue Eng Part A, 2013.

[27] S. K. Both, A. J. van der Muijsenberg, C. A. van Blitterswijk, J. de Boer, and J. D. de Bruijn. A rapid and efficient method for expansion of human mesenchymal stem cells. Tissue Eng, 13(1):3-9, 2007.

[28] M. Dominici, K. Le Blanc, I. Mueller, I. Slaper-Cortenbach, F. Marini, D. Krause, R. Deans, A. Keating, Dj Prockop, and E. Horwitz. Minimal criteria for defining multipotent mesenchymal stromal cells. the international society for cellular therapy position statement. Cytotherapy, 8(4):315-7, 2006.

[29] N. C. Rivron, E. J. Vrij, J. Rouwkema, S. Le Gac, A. van den Berg, R. K. Truckenmuller, and C. A. van Blitterswijk. Tissue deformation spatially modulates vegf signaling and angiogenesis. Proc Natl Acad Sci U S A, 109(18):6886-91, 2012 .

[30] N. C. Rivron, C. C. Raiss, J. Liu, A. Nandakumar, C. Sticht, N. Gretz, R. Truckenmuller, J. Rouwkema, and C. A. van Blitterswijk. Sonic hedgehog-activated engineered blood vessels enhance bone tissue formation. Proc Natl Acad Sci US A, 109(12):4413-8, 2012.

[31] H. Yuan, M. Van Den Doel, S. Li, C. A. Van Blitterswijk, K. De Groot, and J. D. De Bruijn. A comparison of the osteoinductive potential of two calcium phosphate ceramics implanted intramuscularly in goats. J Mater Sci Mater Med, 13(12):1271-5, 2002.

[32] Anindita Chatterjea. Pre-clinical validation of bone tissue engineering using mesenchymal stromal cells. Universiteit Twente, 2012.

[33] K. Janeczek Portalska, M. Dean Chamberlain, C. Lo, C. van Blitterswijk, M. V. Sefton, and J. de Boer. Collagen modules for in situ delivery of mesenchymal stromal cell-derived endothelial cells for improved angiogenesis. J Tissue Eng Regen Med, 2013.

[34] K. J. Portalska, L. M. Teixeira, J. C. Leijten, R. Jin, C. van Blitterswijk, J. de Boer, and M. Karperien. Boosting angiogenesis and functional vascularization in injectable dextran-hyaluronic acid hydrogels by endothelial-like mesenchymal stromal cells. Tissue Eng Part A, 2013.

[35] Shane P. Herbert and Didier Y. R. Stainier. Molecular control of endothelial cell behaviour during blood vessel morphogenesis. Nat Rev Mol Cell Biol, 12(9):551$564,2011$. 


\title{
Chapter 8
}

\section{Endothelial-like mesenchymal stromal cells to promote islets revascularization}

Karolina Janeczek Portalska, Mijke Buitinga, Janneke Hilderink, Eelco de Koning, Marten Engelse, Clemens van Blitterswijk, Marcel Karperien, Aart van Apeldoorn and Jan de Boer

\begin{abstract}
Proper tissue vascularization is necessary to maintain tissue homeostasis since it ensures an appropriate level of oxygen and nutrients. Therefore, one of the major challenges in regenerative medicine and transplantology is to enforce vascular engraftment of the newly formed or implanted tissues and, by that, assure its survival and success of the therapy. The time necessary to provide adequate vascularization is particularly important when implanted tissue has a high metabolic rate or needs to respond quickly to external signals, like in the case of transplantation of pancreatic islets. Such transplantation is considered as a possible alternative for whole pancreas transplantation for patients with diabetes type 1 , but the vascularization of these structures needs to be improved to allow for successful diabetes treatment. One of the widely investigated methods to improve islet vascularization is combining the islets with cells that will improve angiogenesis and vasculogenesis of the graft. In this study we show that clinically relevant mesenchymal stem cell-derived endothelial cells (EL-MSC) improve the sprouting of islets in vitro without hampering their functionality. We also show that covering the islets with EL-MSCs ensures better vasculogenic potential as compared to previously tested endothelial and mesenchymal stem cell-based strategies.
\end{abstract}

\subsection{Introduction}

Recent clinical trials have demonstrated the ability of allogeneic islet transplants to regulate blood glucose levels in patients with type 1 diabetes $[1] 3]$. The main benefit 
of this procedure compared to whole organ transplantation, is the significant reduction of glycemic fluctuations while having reduced postoperative trauma and complication rates. One of the most restricting factors of this therapy though, is the large number of islets necessary to achieve long-term normoglycemia after transplantation. Islets from at least two donors are needed to cure one patient. Besides, insulin independence lasts for only a few years, due to progressive islet loss in the post-transplantation period $1,3,4$.

A factor considered to be detrimental for islet survival and function is inadequate revascularization of the transplanted islets. When islets are isolated from a donor pancreas, their vascular connections are disrupted and it takes several days in vivo before an initial vascular supply is established [5, 6. Therefore, immediately after transplantation, islets solely depend on oxygen and nutrient transport by diffusion. Although new blood vessels are formed within transplanted islets, the resulting vascular density is chronically lower compared with that of native islets [7, 8], resulting in a 95 percent reduction in blood perfusion in mice 9 . Since the vascular network is important to maintain the islets' oxygen-dependent nutrient metabolism and their ability to quickly secrete insulin in response to changes in blood glucose levels, a reduction in blood perfusion will affect both islet survival and function.

Hence, various attempts have been made to improve vascularization of islets after transplantation. One of these attempts is to increase the action of pro-angiogenic factors or to inhibit anti-angiogenic factors in order to stimulate the proliferation, migration, and maturation of endothelial cells $10-12$. Precise control of timing, dose and duration of factor administration remains the challenge in order to get mature, functional blood vessels within islets. Another approach is to directly use endothelial cells, endothelial progenitor cells, or mesenchymal stromal cells (MSCs).

Johansson et al. [13] have shown that coating human islets with endothelial cells initiates the formation of vessel-like structures in vitro, without impairing islet functionality. The sprouting capacity of endothelial cell-coated islets was further improved by the addition of MSCs. Other studies have shown that co-transplanting islets with stromal cells derived from various sources can induce neovascularization, resulting in enhanced islet revascularization 14,17 and better function $14-18$, regardless whether the implantation site was under the kidney capsule $14,15,17,19]$, in the liver [17] or subcutaneously in a fibrin gel [15]. In most of these studies, islets were co-injected with undifferentiated adipose-derived [15] or bone-marrow derived MSCs [15, 17, 19], while Oh et al. co-transplanted islets with murine bone-marrow derived endothelial progenitor cells 14]. A direct comparison of the efficiency of revascularization between the various studies using different cell populations is difficult though, because of differences in species, transplantation sites, detection methods, and in amount of transplanted cells.

Recently, we have demonstrated that we are able to obtain MSCs with specific endothelial cell properties by culturing them in endothelial growth medium in the presence of shear force and extracellular matrix stimuli 2022 . These endotheliallike MSCs (EL-MSC) were shown to acquire specific endothelial cell properties, both 
phenotypical and functional. EL-MSCs 1) express typical endothelial markers CD31 and KDR, 2) form capillary-like structures on Matrigel and 3) improve vascularization of implanted constructs, both via trophic pro-angiogenic effects and via contributing to the in-growing vessel walls 2022 . Therefore, we hypothesize that EL-MSCs promote better islet revascularization compared to naïve MSCs, and thereby improve islet survival and function. The advantage of EL-MSCs over endothelial cells (ECs) is that they can be easily isolated in substantial quantities, which is relevant for therapeutic applications. We have also demonstrated that their endothelial properties are independent of the donor and can be therefore autologous to the patient.

To prove the utility of these cells in islet revascularization, we have coated human islets of Langerhans with EL-MSCs and checked whether in such a combination islet vascularization improves. In this manuscript, we present an efficient and reproducible technique for the formation of EL-MSC-covered islets. Our data demonstrates that replacing previously described MSC and EC-MSC coatings with EL-MSC coatings enhances the sprouting capacity of the composite without compromising islet functionality.

\subsection{Research design and methods}

\subsubsection{Islet of Langerhans isolation and culture}

Human islets of Langerhans were obtained from the Human Islet Isolation Laboratory at the Leiden University Medical Center (Leiden, The Netherlands), which has permission from the Dutch government to isolate human islets for clinical and research purposes. Human islets that were not eligible for clinical transplantation were used in these experiments, in accordance with Dutch law and institutional requirements. Islets were cultured in islet medium (CMRL-1066, Mediatech, Cellgro, Herndon, USA), supplemented with 10\% FBS (Lonza), $100 \mathrm{U} / \mathrm{ml}$ penicillin (GIBCO), and $10 \mu \mathrm{g} / \mathrm{ml}$ streptomycin (GIBCO).

\subsubsection{Cell isolation and culture}

Human mesenchymal stromal cells (MSCs) were isolated from human bone marrow from donors with written informed consent 23. Aspirates were resuspended using a $20 \mathrm{G}$ needle and plated at a density of 0.5 million mono-nucleated cells per $\mathrm{cm}^{2}$. Cells were grown in MSC proliferation medium (alfa-MEM (GIBCO), supplemented with 10\% FBS (Lonza), $100 \mathrm{U} / \mathrm{ml}$ penicillin (GIBCO), $10 \mu \mathrm{g} / \mathrm{ml}$ streptomycin (GIBCO), $2 \mathrm{mM}$ L-glutamin (GIBCO), $0.2 \mathrm{mM}$ L-ascorbic acid 2-phosphate magnesium salt (Sigma-Aldrich) and $1 \mathrm{ng} / \mathrm{ml}$ bFGF (Fisher Scientific) at $37^{\circ} \mathrm{C}$ in a humid atmosphere with $5 \% \mathrm{CO}_{2}$. Cells were expanded up to passage 2. For further experiments MSCs from different donors and one immortalized clone (iMSCs, courtesy of Prof. Ola Myklebost, University of Oslo, Norway) were cultured in basic medium (alfa-MEM supplemented with $10 \% \mathrm{FBS}, 100 \mathrm{U} / \mathrm{ml}$ penicillin, $10 \mu \mathrm{g} / \mathrm{ml}$ streptomycin, $2 \mathrm{mM}$ L-glutamin and $0.2 \mathrm{mM} \mathrm{ASAp).} \mathrm{Human} \mathrm{umbilical} \mathrm{vein} \mathrm{endothelial} \mathrm{cells} \mathrm{(HUVECs,}$ Lonza) were cultured in endothelial growth medium (EGM-2, Lonza). 


\subsubsection{Endothelial induction of MSCs}

iMSCs (passage 25) and MSCs from 5 different donors (passage 1-2) were used for an endothelial induction protocol, as described previously $[20$. Cells were seeded at a density of 3,000 cells per $\mathrm{cm}^{2}$ on tissue culture plastic in EGM-2 and cultured for 10 days. After one day in static culture, shear force was applied using an orbital shaker (20 rpm). Cells that were cultured according to this protocol will be referred to as EL-MSCs.

\subsubsection{Cell labelling}

When indicated, MSCs (both naïve and EL-MSCs) and HUVECs were labelled using DiI (red) and/or DiO (green), respectively, according to the manufacturer's protocol (Life Technologies).

\subsubsection{Islet coating}

Agarose chips containing microwells were prepared by replica moulding as described previously [24]. Briefly, replicates of patterned PDMS (poly-dimethylsiloxane) stamps, each containing 130 pillars with a diameter of $400 \mu \mathrm{m}$ and a height of $200 \mu \mathrm{m}$, were prepared using 3\% agarose solution (Ultra-pure agarose, Invitrogen). Before cell seeding, the agarose chips were incubated $\mathrm{o} / \mathrm{n}$ in islet culture medium. After uniformly seeding the islets of Langerhans in the microwells of each chip, a single cell suspension of naïve MSCs, a mixture of naïve MSCs and HUVECs, or EL-MSCs was added. Different cell concentrations (300, 625, and 1250 cells/islet) were tested in order to obtain uniform islet coating. The chips were then shortly centrifuged at $1500 \mathrm{rpm}$. Cells attached to the surface of the islets within o/n culture in EGM-2 medium. Coating efficiency was estimated based on pictures taken with Nikon Elipse E600 microscope.

\subsubsection{Glucose-induced insulin secretion test}

To assess islet functionality, a glucose-induced insulin secretion test was performed at day 1 and day 5 after islet coating. Per condition per islet donor, 100 islets were handpicked, seeded in the agarose chips, and coated $\mathrm{o} / \mathrm{n}$ with naïve MSCs (1250 cells/islet), a mixture of naïve MSCs (625 cells/islet) and HUVECs (1250 cells/islet), or EL-MSCs (1250 cells/islet). As a control, uncoated islets were cultured $\mathrm{o} / \mathrm{n}$ in agarose chips. Islet coating was performed in EGM-2 medium, after which the islets were cultured for 5 days in islet medium, with a medium change every day. For the glucose-induced insulin secretion test, per condition 30 islets (in triplicate) were incubated for 90 minutes in a modified Krebs Ringer Bicarbonate (KRBH) buffer (115 mM NaCl, $5 \mathrm{mM} \mathrm{KCl,} 24 \mathrm{mM} \mathrm{NaHCO}_{3}$ and $2.2 \mathrm{mM} \mathrm{CaCl} 2, \mathrm{pH} 7.4$ ), $20 \mathrm{mM}$ HEPES, and $2 \mathrm{mg} / \mathrm{ml}$ human serum albumin (Cealb, Sanquinm The Netherlands). Islets were successively incubated for 1 hour in $\mathrm{KRBH}$ buffer with $1.7 \mathrm{mM}$ and 16.7 $\mathrm{mM}$ D-glucose at $37^{\circ} \mathrm{C}$. Insulin concentration was determined in the supernatants by ELISA (Mercodia, Sweden). The experiment was performed separately for three different islet donors, each time coated with MSCs from another donor. 


\subsubsection{Sprouting assay on Matrigel and fibrin gel}

For the Matrigel sprouting assay, control (uncoated), naïve MSC, HUVEC/ naïve MSC, and EL-MSC coated islets were placed between 2 layers of growth factor reduced Matrigel (BD Biosciences) diluted 1:1 in EGM-2 medium. For fibrin gel assay, control (uncoated), naïve MSC, HUVEC/ naïve MSC, and EL-MSC islets were placed between 2 layers of fibrin gel $(2.5 \mathrm{mg} / \mathrm{ml}$ fibrinogen and $2 \mu \mathrm{g} / \mathrm{ml}$ thrombin; SigmaAldrich). For each gel layer $1 \mathrm{ml}$ of gel was used. After polymerization, islets were cultured for 96 hours in EGM-2 medium. Islet sprouting was observed over time using an inverted microscope (Nikon Eclipse TE300). Pictures were taken at different time points (24, 48 and 96 hours) using a Nikon DS-L2 camera. Matrigel assay was performed with islets obtained from 6 different islet donors, while fibrin assay with islets from 4 islet donors. hMCSs from 5 different donors and one clone of iMSCs were used in this study. Sprouts (independent of their length) were counted manually by a single person (blinded to the composition of the islet preparation), and a minimum of 10 islets were counted per group.

\subsubsection{Statistics}

Each experiment was performed in triplicate. Data that required multiple comparison test was analysed in SPSS (PASW statistics) using one-way Anova followed by Tukey's multiple comparison test $(\mathrm{P}<0.05)$.

\subsection{Results}

\subsubsection{Optimal islet coating using agarose microwell chips}

Since EL-MSCs were observed to create big clumps when incubated in microcentrifuge tubes (data not shown) we modified the coating protocol published by Johansson et al. 13. To fabricate aggregates of islets and single cells, we used a nonadherend agarose microwell culture platform which has been developed in our group for cell and cell cluster aggregation 25. To determine the cell concentration for optimal islet coating, three different cell concentrations of DiI labelled MSCs were applied to human islets. As can be observed in Figure 8.1, MSCs tend to aggregate and attach as a cell cluster to the islets within 24 hours. When increasing the cell density up to 1250 cells per, the coating was more uniform and the majority of the islets' surface was covered with MSCs.

\subsubsection{Coating islets with EL-MSCs does not affect islet functionality}

To assess whether the applied coatings affect islet functionality, the ability of the islets to respond to a glucose challenge with adequate levels of insulin, was measured. Regardless whether the islets were coated with cells or not, a stimulation with 16.7 $\mathrm{mM}$ glucose buffer led to a two to threefold increase in insulin secretion compared to basal insulin release levels (Figure 8.2). Both at day 1 and 5 after islet coating, no 

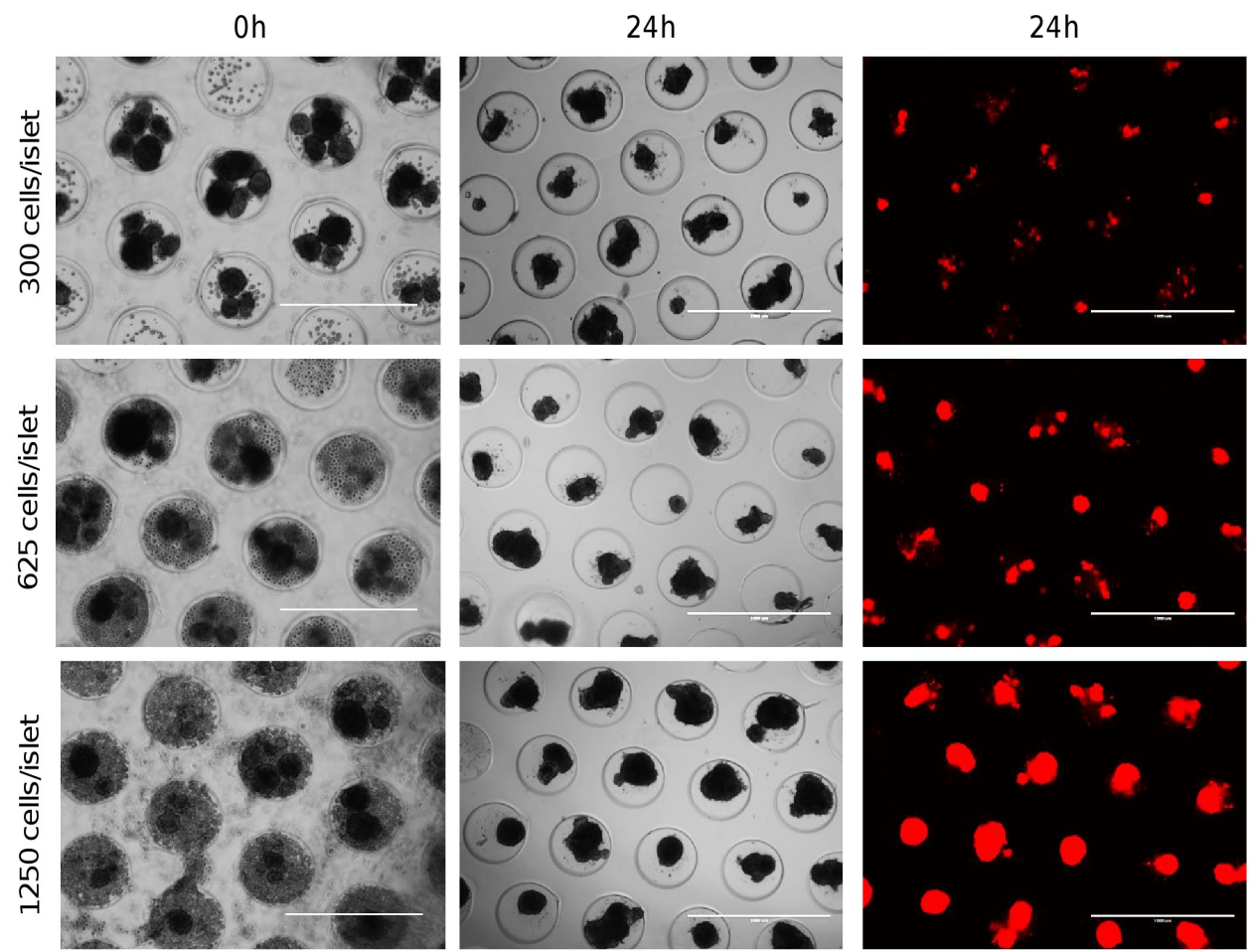

Figure 8.1: Efficiency of islets coating with various cell types. Islets were centrifuged into microwells after what various amount of cells (stained with DiI) was added. Scale bar $1 \mathrm{~mm}$.

significant differences in relative insulin secretion levels could be observed between coated and uncoated islets. When applying the low glucose buffer of $1.7 \mathrm{mM}$, insulin secretion of all conditions decreased to basal insulin levels again. This implies that the cell coatings did not affect the islets' secretory capacity upon glucose stimulation.

\subsubsection{Matrigel sprouting assay}

To evaluate the effect of cell coating on islet sprouting, uncoated (control) and coated (MSC, EL-MSC, HUVEC/MSC and HUVEC/EL-MSC) islets were cultured between two layers of Matrigel (Figure 8.3A). We have chosen for Matrigel in the first place as a sprouting matrix since we have previously performed sprouting assays within this gel and fully functional EL-MSCs were obtained only after contact with this matrix. To determine which cell type contributes to the sprouts in case of co-culture, DiI and DiO cell labelling was applied. In the case of islets covered with two different cell types, sprouts were formed by both MSCs / EL-MSCs (red) and HUVECs (green). The close 


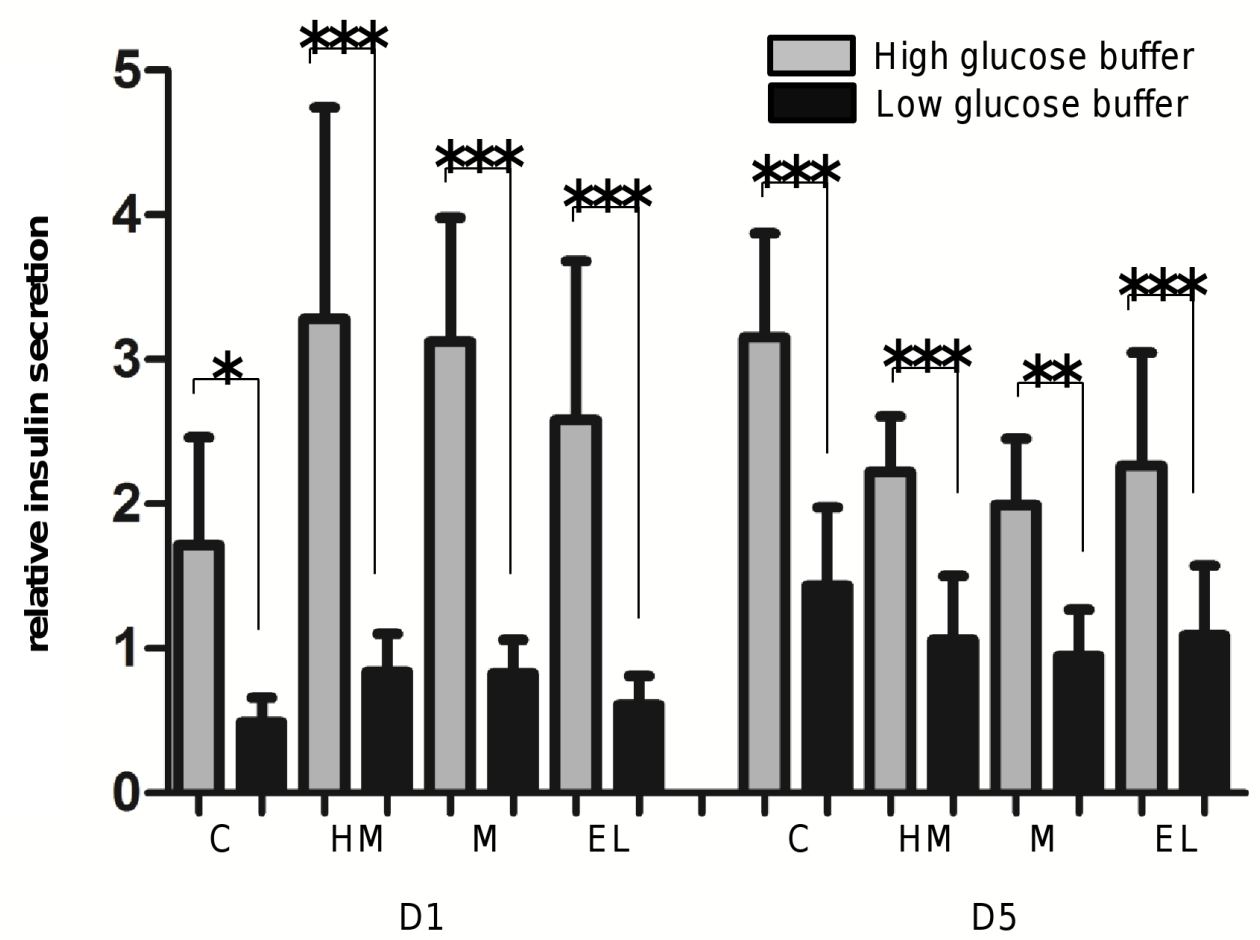

Figure 8.2: Islets functionality after coating with various cell types. The insulin production was measured in low and high glucose buffer, 1 and 5 days after coating with cells. Control islets (C), HUVEC-MSC islets (HM), MSC islets (M) and EL-MSC islets (EL). Bars on the graph represent mean of insulin secretion normalized towards insulin secretion in islets incubated in low glucose buffer \pm standard deviation, $*$ denotes statistical significance $(\mathrm{p}$ $<0.05),{ }^{* *}$ denotes statistical significance $(\mathrm{p}<0.01), * * *$ denotes statistical significance $(\mathrm{p}<0.001)$.

contact between MSCs and HUVECs within one sprout can be observed in Figure 8.3B. Sprout quantification revealed that already after 24 hours the average number of sprouts per islet was significantly higher in case of islets covered with EL-MSCs and HUVECs/EL-MSCs than in case of islets covered with MSCs or HUVECs/MSCs (Figure $8.3 \mathrm{C}$ ). This advantage remained unchanged after 48 and 96 hours. Uncoated islets obtained from all 6 donors did not sprout in Matrigel even after 96 hours from seeding. Islets coated with HUVECs alone were used for the initial study (data not shown) and sprouting observed in this group was very inefficient, as shown previously by Johansson et al. [13. Therefore, we have excluded this group from further study. 
A
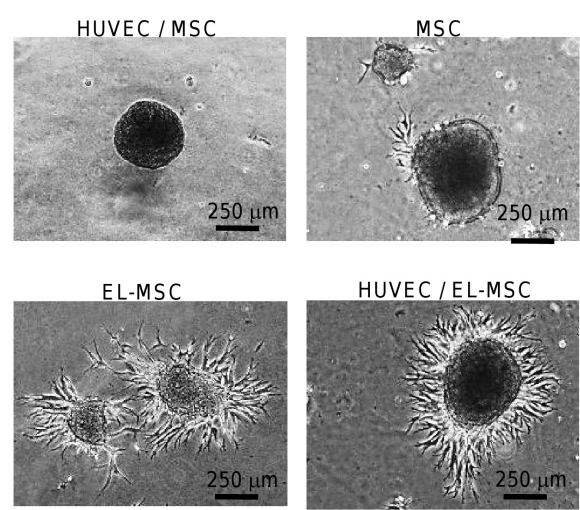

HUVEC / EL-MSC

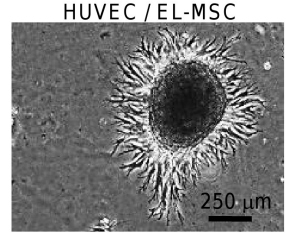

B

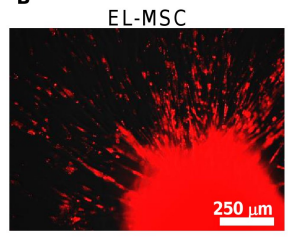

HUVEC / MSC
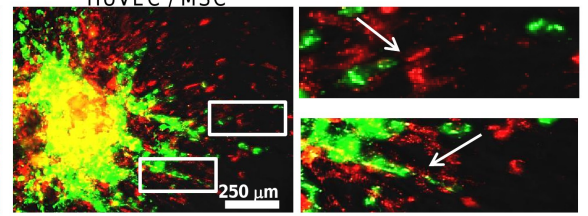

C

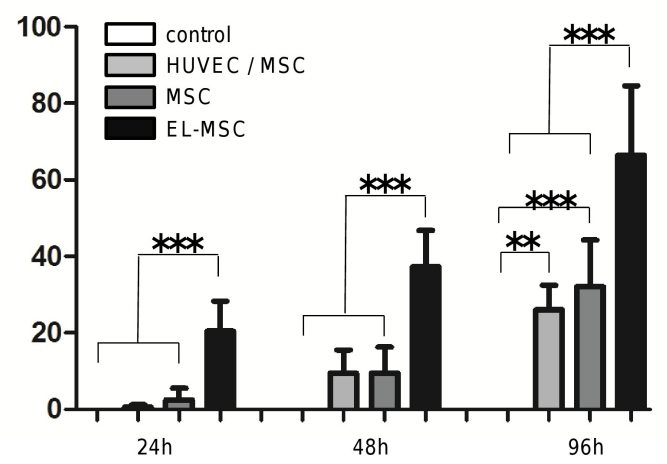

Figure 8.3: Sprout formation in Matrigel gel. Phase contrast microscope images taken 24hours after seeding: control (uncoated) islets, HUVEC-MSC islets, MSC islets and EL-MSC islets (A). Fluorescent microscope images taken 48h after seeding (B). HUVECs were stained with DiO (green), MSCs and ELMSCs with DiI (red). Sprouts built of MSCs and HUVECs in close contact can be observed (white arrows). The number of sprouts per islet after 24,48 and 96 hours in culture $(\mathrm{C})$. Mean of total sprout count \pm standard deviation, ** denotes statistical significance $(\mathrm{p}<0.01)$, *** denotes statistical significance $(\mathrm{p}<0.001)$. Uncoated islets did not sprout in Matrigel. 


\subsubsection{Fibrin gel sprouting assay}

We have also compared our results with the ones previously described 13 by assessing the sprouting of islets within fibrin gel. Uncoated (control) and coated (MSC, ELMSC and HUVEC/MSC) islets were cultured between two layers of fibrin gel (Figure 8.4A). EL-MSC / HUVEC coating was not included in this study since Matrigel assay did not show any additional sprouting improvement when compared with islets coated with EL-MSCs only. As shown previously [13], uncoated islets have the ability to sprout in fibrin gel. Nevertheless, the average number of sprouts per islet was significantly improved in case of each coating. The effect was most striking in case of EL-MSC coating, where the average number of sprouts per islet was 15, 10 and 6 times higher after 24, 48 and 96 hours, respectively. Other coatings were significantly less efficient in inducing islet sprouting, leading to average 7,6 and 4 fold increase (time points as above) in the number of sprouts per islet.

\subsection{Discussion}

To ensure that implanted islets of Langerhans exert their therapeutic effect to diabetic patients, insulin and glucagon produced by the these micro organs needs to be secreted directly into the blood flow. Therefore, islets need to be surrounded by a dense capillary network upon implantation as soon as possible. During the process of islet isolation prior to transplantation, the capillaries in the islets loose the connection with external vessels and decay [26]. Thus, recovering of capillary network within the islets is also an important part of the treatment. Various tissue engineering techniques were applied to improve the process of islet vascularization upon implantation, but none of the previously described solutions guarantee a clinically sufficient vascularization level. Furthermore, some of these studies were based on cell types, e.g. HUVECs, that cannot be used for therapy.

Bone-marrow-derived MSCs are ideal cell candidates for tissue engineering in regenerative medicine. They can easily be obtained in quantities sufficient for application in various therapies [27]. Moreover, there is no controversy concerning the safety of applying these cells in therapy, since they were successfully used for numerous clinical studies in the past 28 . We have shown lately that EL-MSCs derived from MSCs do not lose endothelial characteristics after implantation and are able to improve construct vascularization 20, 21]. We have also demonstrated that EL-MSCs surpass truly endothelial cells as far as the ability for surrounding matrix remodelling is compared 24. This feature is extremely important since the formation of new capillaries during revascularization is a complex process that involves tissue digestion to provide space for new vasculature, much needed when dense organs such as islets are involved 29]. The in-growth of host blood vessels is also faster in the presence of cells able to remodel extracellular matrix 21,30 .

In this study we demonstrated that EL-MSCs can improve islet vascularization. We showed that EL-MSC-coated islet constructs were able to show fast and efficient 
A
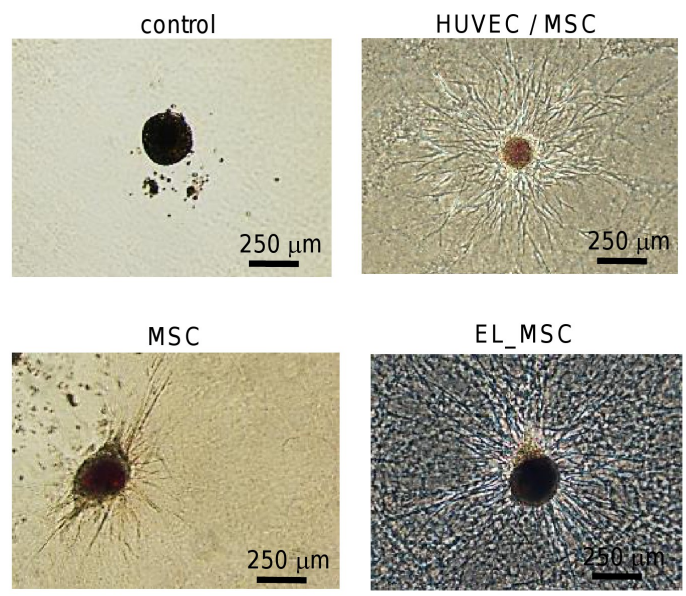

B

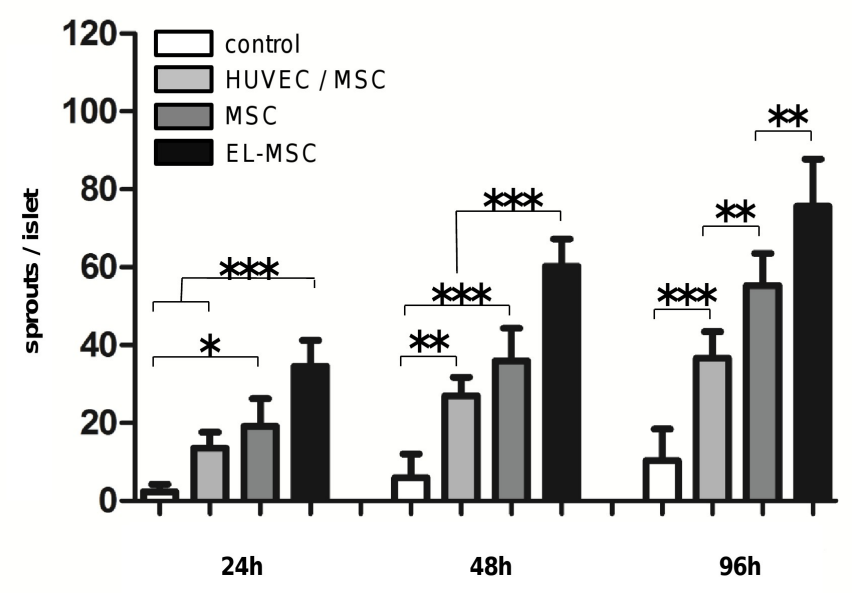

Figure 8.4: Sprout formation in fibrin gel. Phase contrast microscope images taken 48 hours after seeding of control (uncoated) islets, HUVEC-MSC islets, MSC islets and EL-MSC islets (A). The number of sprouts per islet after 24, 48 and 96 hours in culture (B). Mean of total sprout count \pm standard deviation, ${ }^{*}$ denotes statistical significance $(\mathrm{p}<0.05)$, ** denotes statistical significance $(\mathrm{p}<0.01),{ }^{* * *}$ denotes statistical significance $(\mathrm{p}<0.001)$.

sprouting through surrounding matrixes. This offers a possibility of significant improvement in the speed of capillary network formation when EL-MSC-covered islets are implanted. As demonstrated in our previous study [27], implanted EL-MSCs do not only prepare a route for in-growing of host vessels but also participate in vessel formation. Additionally, even undifferentiated MSCs are known to secrete a wide 
range of cytokines and growth factors, which have both immunomodulatory and proangiogenic properties 31,32 . It is likely that the trophic effect of EL-MSCs is even larger, since these cells were cultured in growth-factor-rich medium that can induce additional pro-angiogenic molecule secretion. The most compelling evidence for a trophic role of EL-MSCs in attracting vessel in-growth comes from our previous work in which MSCs and EL-MSCs were transplanted in collagen modules as delivery vehicles. In-growth of vessels was increased in modules loaded with both cell types while collagen modules themselves did not support vessel ingrowth [24]. In this study ELMSCs provided more stable capillary structure within the implanted construct than MSCs. Furthermore, MSCs were reported to have an ability to limit the progress of the graft-versus-host disease [33, 34]. It is possible that EL-MSCs keep this capability and therefore their introduction can have an additional positive effect on the therapy when transplantation of islets is required.

To show the potential of EL-MSCs in improving islets vascularization we used well established models of angiogenesis, namely Matrigel and fibrin assay. We have shown that induction of sprout formation within both gels significantly improved in the presence of EL-MSCs as compared to previously reported HUVEC/MSC complexes. Additionally, the introduction of MSCs did not enhance this effect which signifies that EL-MSCs were able to take both the function of endothelial cells as well as the function of MCSs. Reducing the number of cell types involved in preparation of the engineered construct not only simplifies the development itself but also enables faster clinical introduction, especially due to the fact that MSCs are already allowed in clinical studies provided that isolation and in vitro maintenance is performed according to guidelines. To introduce any other cell type for improving islet vascularization, numerous additional studies need to be performed. First, the cells themselves must be proven safe for patients. Such research is very time consuming and expensive due to the necessity of animal studies in various animal models followed by clinical studies with human patients. Moreover, isolation methods and media used for in vitro maintenance of each cell type need to be described and FDA-approved. Therefore, choosing cells that are already tested greatly reduces the amount of studies necessary for bench to bedside transition.

The study described herein also showed that the effect of improved angiogenic potential of islets covered by EL-MSCs is not donor-dependent. As described previously [35, MSCs obtained from all tested donors were able to differentiate into EL-MSCs. The present study extends this statement from phenotypical characteristics only towards the functional potential that was shown before with cells obtained from a limited number of donors 20].

Moreover, no negative influence on islet functionality has been observed after the coating, as demonstrated in the test were insulin secretion was measured after challenging the islets with various glucose levels.

Finally, we also demonstrated the possibility of using iMSCs as model cells for studying not only phenotypical changes of MSCs after differentiation as described 
previously [20], but also to study the interactions between islets of Langerhans and MSCs. This simplifies the realization of future in vivo experiments that are necessary to prove the utility of our design for diabetes therapy. We are currently working on the best delivery method of the EL-MSC-coated islets into patients. Based on our previous experience with collagen 21$]$ and dextran $[22$ gels as well as our research concerning PEOT/PBT block copolymers [36, we are looking for optimal ways of construct preparation that would host the necessary number of islets allowing for fast vascularization and proper islet functioning.

To conclude, promising results obtained with EL-MSC-islet constructs strongly suggest that such constructs can contribute to the success of implantations strategies in diabetes therapy. 


\subsection{Bibliography}

[1] Edmond A. Ryan, Breay W. Paty, Peter A. Senior, David Bigam, Eman Alfadhli, Norman M. Kneteman, Jonathan R.T. Lakey, and A.M. James Shapiro. Five-year follow-up after clinical islet transplantation. Diabetes, 54(7):2060-2069, 2005.

[2] A. M. Shapiro, J. R. Lakey, E. A. Ryan, G. S. Korbutt, E. Toth, G. L. Warnock, N. M. Kneteman, and R. V. Rajotte. Islet transplantation in seven patients with type 1 diabetes mellitus using a glucocorticoid-free immunosuppressive regimen. N Engl J Med, 343(4):230-8, 2000.

[3] Franca B. Barton, Michael R. Rickels, Rodolfo Alejandro, Bernhard J. Hering, Stephen Wease, Bashoo Naziruddin, Jose Oberholzer, Jon S. Odorico, Marc R. Garfinkel, Marlon Levy, Francois Pattou, Thierry Berney, Antonio Secchi, Shari Messinger, Peter A. Senior, Paola Maffi, Andrew Posselt, Peter G. Stock, Dixon B. Kaufman, Xunrong Luo, Fouad Kandeel, Enrico Cagliero, Nicole A. Turgeon, Piotr Witkowski, Ali Naji, Philip J. O'Connell, Carla Greenbaum, Yogish C. Kudva, Kenneth L. Brayman, Meredith J. Aull, Christian Larsen, Tom W.H. Kay, Luis A. Fernandez, Marie-Christine Vantyghem, Melena Bellin, and A.M. James Shapiro. Improvement in outcomes of clinical islet transplantation: 1999-2010. Diabetes Care, 35(7):1436-1445, 2012.

[4] M. C. Vantyghem, J. Kerr-Conte, L. Arnalsteen, G. Sergent, F. Defrance, V. Gmyr, N. Declerck, V. Raverdy, B. Vandewalle, P. Pigny, C. Noel, and F. Pattou. Primary graft function, metabolic control, and graft survival after islet transplantation. Diabetes Care, 32(8):1473-8, 2009.

[5] M. D. Menger, J. Yamauchi, and B. Vollmar. Revascularization and microcirculation of freely grafted islets of langerhans. World J Surg, 25(4):509-15, 2001.

[6] C. Kampf, G. Mattsson, and P. O. Carlsson. Size-dependent revascularization of transplanted pancreatic islets. Cell Transplant, 15(2):205-9, 2006.

[7] Göran Mattsson, Leif Jansson, and Per-Ola Carlsson. Decreased vascular density in mouse pancreatic islets after transplantation. Diabetes, 51(5):1362-1366, 2002.

[8] Joey Lau, Caroline Kampf, Göran Mattsson, Daniel Nyqvist, Martin Köhler, Per-Olof Berggren, and Per-Ola Carlsson. Beneficial role of pancreatic microenvironment for angiogenesis in transplanted pancreatic islets. Cell Transplantation, 18(1):23-30, 2009.

[9] J. Henriksnas, J. Lau, G. Zang, P. O. Berggren, M. Kohler, and P. O. Carlsson. Markedly decreased blood perfusion of pancreatic islets transplanted intraportally into the liver: disruption of islet integrity necessary for islet revascularization. Diabetes, 61(3):665-73, 2012.

[10] J. Olerud, M. Johansson, J. Lawler, N. Welsh, and P. O. Carlsson. Improved vascular engraftment and graft function after inhibition of the angiostatic factor thrombospondin-1 in mouse pancreatic islets. Diabetes, 57(7):1870-7, 2008. 
[11] Y. Lai, D. Schneider, A. Kidszun, I. Hauck-Schmalenberger, G. Breier, D. Brandhorst, H. Brandhorst, M. Iken, M. D. Brendel, R. G. Bretzel, and T. Linn. Vascular endothelial growth factor increases functional beta-cell mass by improvement of angiogenesis of isolated human and murine pancreatic islets. Transplantation, 79(11):1530-6, 2005.

[12] N. Zhang, A. Richter, J. Suriawinata, S. Harbaran, J. Altomonte, L. Cong, H. Zhang, K. Song, M. Meseck, J. Bromberg, and H. Dong. Elevated vascular endothelial growth factor production in islets improves islet graft vascularization. Diabetes, 53(4):963-70, 2004.

[13] U. Johansson, I. Rasmusson, S. P. Niclou, N. Forslund, L. Gustavsson, B. Nilsson, O. Korsgren, and P. U. Magnusson. Formation of composite endothelial cellmesenchymal stem cell islets: a novel approach to promote islet revascularization. Diabetes, 57(9):2393-401, 2008.

[14] B. J. Oh, S. H. Oh, S. M. Jin, S. Suh, J. C. Bae, C. G. Park, M. S. Lee, M. K. Lee, J. H. Kim, and K. W. Kim. Co-transplantation of bone marrow-derived endothelial progenitor cells improves revascularization and organization in islet grafts. Am J Transplant, 13(6):1429-40, 2013.

[15] M. Figliuzzi, R. Cornolti, N. Perico, C. Rota, M. Morigi, G. Remuzzi, A. Remuzzi, and A. Benigni. Bone marrow-derived mesenchymal stem cells improve islet graft function in diabetic rats. Transplant Proc, 41(5):1797-1800, 2009.

[16] Suk Ho Bhang, Min Jin Jung, Jung-Youn Shin, Wan-Geun La, Yong Hwa Hwang, Min Jun Kim, Byung-Soo Kim, and Dong Yun Lee. Mutual effect of subcutaneously transplanted human adipose-derived stem cells and pancreatic islets within fibrin gel. Biomaterials, 34(30):7247-7256, 2013.

[17] T. Ito, S. Itakura, I. Todorov, J. Rawson, S. Asari, J. Shintaku, I. Nair, K. Ferreri, F. Kandeel, and Y. Mullen. Mesenchymal stem cell and islet co-transplantation promotes graft revascularization and function. Transplantation, 89(12):1438-45, 2010 .

[18] Chloe Louise Rackham, Paramjeet Kaur Dhadda, Pedro Cesar Chagastelles, Sian Jazmine Shakara Simpson, Anshi Anjili Dattani, James Edward Bowe, Peter Martin Jones, and Aileen Jean Fiona King. Pre-culturing islets with mesenchymal stromal cells using a direct contact configuration is beneficial for transplantation outcome in diabetic mice. Cytotherapy, 15(4):449-459, 2013.

[19] N. Sakata, N. K. Chan, J. Chrisler, A. Obenaus, and E. Hathout. Bone marrow cell cotransplantation with islets improves their vascularization and function. Transplantation, 89(6):686-93, 2010.

[20] K. Janeczek Portalska, A. Leferink, N. Groen, H. Fernandes, L. Moroni, C. van Blitterswijk, and J. de Boer. Endothelial differentiation of mesenchymal stromal cells. PLoS One, 7(10):e46842, 2012. 
[21] K. Janeczek Portalska, M. Dean Chamberlain, C. Lo, C. van Blitterswijk, M. V. Sefton, and J. de Boer. Collagen modules for in situ delivery of mesenchymal stromal cell-derived endothelial cells for improved angiogenesis. J Tissue Eng Regen Med, 2013.

[22] K. Janeczek Portalska, L. M. Teixeira, J. C. Leijten, R. Jin, C. van Blitterswijk, J. de Boer, and M. Karperien. Boosting angiogenesis and functional vascularization in injectable dextran-hyaluronic acid hydrogels by endothelial-like mesenchymal stromal cells. Tissue Eng Part A, 2013.

[23] S. K. Both, A. J. van der Muijsenberg, C. A. van Blitterswijk, J. de Boer, and J. D. de Bruijn. A rapid and efficient method for expansion of human mesenchymal stem cells. Tissue Eng, 13(1):3-9, 2007.

[24] A. Chatterjea, H. Yuan, S. Chatterjea, H. Garritsen, A. Renard, C. A. van Blitterswijk, and J. de Boer. Engineering new bone via a minimally invasive route using human bone marrow-derived stromal cell aggregates, microceramic particles, and human platelet-rich plasma gel. Tissue Eng Part A, 19(3-4):340-9, 2013.

[25] Eelco Fennema, Nicolas Rivron, Jeroen Rouwkema, Clemens van Blitterswijk, and Jan de Boer. Spheroid culture as a tool for creating 3d complex tissues. Trends in Biotechnology, 31(2):108-115, 2013.

[26] M. Giuliani, W. Moritz, E. Bodmer, D. Dindo, P. Kugelmeier, R. Lehmann, M. Gassmann, P. Groscurth, and M. Weber. Central necrosis in isolated hypoxic human pancreatic islets: evidence for postisolation ischemia. Cell Transplant, 14(1):67-76, 2005.

[27] E. M. Fennema, A. J. Renard, A. Leusink, C. A. van Blitterswijk, and J. de Boer. The effect of bone marrow aspiration strategy on the yield and quality of human mesenchymal stem cells. Acta Orthop, 80(5):618-21, 2009.

[28] H. K. Salem and C. Thiemermann. Mesenchymal stromal cells: current understanding and clinical status. Stem Cells, 28(3):585-96, 2010.

[29] E. M. Conway, D. Collen, and P. Carmeliet. Molecular mechanisms of blood vessel growth. Cardiovasc Res, 49(3):507-21, 2001.

[30] T. P. Cooper and M. V. Sefton. Fibronectin coating of collagen modules increases in vivo huvec survival and vessel formation in scid mice. Acta Biomater, 7(3):1072-83, 2011.

[31] J. Doorn, G. Moll, K. Le Blanc, C. van Blitterswijk, and J. de Boer. Therapeutic applications of mesenchymal stromal cells: paracrine effects and potential improvements. Tissue Eng Part B Rev, 18(2):101-15, 2012.

[32] D. Kaigler, P. H. Krebsbach, P. J. Polverini, and D. J. Mooney. Role of vascular endothelial growth factor in bone marrow stromal cell modulation of endothelial cells. Tissue Eng, 9(1):95-103, 2003. 
[33] O. Ringden, M. Uzunel, I. Rasmusson, M. Remberger, B. Sundberg, H. Lonnies, H. U. Marschall, A. Dlugosz, A. Szakos, Z. Hassan, B. Omazic, J. Aschan, L. Barkholt, and K. Le Blanc. Mesenchymal stem cells for treatment of therapyresistant graft-versus-host disease. Transplantation, 81(10):1390-7, 2006.

[34] K. Le Blanc, I. Rasmusson, B. Sundberg, C. Gotherstrom, M. Hassan, M. Uzunel, and O. Ringden. Treatment of severe acute graft-versus-host disease with third party haploidentical mesenchymal stem cells. Lancet, 363(9419):1439-41, 2004.

[35] K. Janeczek Portalska, N. Groen, G. Krenning, N. Georgi, A. Mentink, M. C. Harmsen, C. van Blitterswijk, and J. de Boer. The effect of donor variation and senescence on endothelial differentiation of human mesenchymal stromal cells. Tissue Eng Part A, 2013.

[36] M. Buitinga, R. Truckenmuller, M. A. Engelse, L. Moroni, H. W. Ten Hoopen, C. A. van Blitterswijk, E. J. de Koning, A. A. van Apeldoorn, and M. Karperien. Microwell scaffolds for the extrahepatic transplantation of islets of langerhans. PLoS One, 8(5):e64772, 2013. 


\section{Chapter 9}

\section{General discussion}

\subsection{Tissue engineering of blood vessels}

Regenerative medicine emerged as an answer to the necessity of healing large tissue damage and defects which surpass the self-regeneration potential of these tissues. Since the amount of organs available from donations is much too low to serve all the patients in need, other solutions must be found to fill this gap.

Tissues are capable of repairing themselves in a variety of ways. Some of them contain a population of cells that undergo constant asymmetric divisions, giving rise to cells that keep proliferating and to cells that differentiate. This situation is common in tissues that are exposed to constant wear or renewal, such as skin, blood and intestines. Other tissues that in principle do not require constant cell replacement, usually include some specialized cells that can start proliferation and give rise to cells able to repair small tissue damage after injury. An example of such cells are for instance satellite cells found in muscle tissue.

In 1970 Friedenstein et al. described a population of cells that can be found in various tissues [1]. These cells, currently called human mesenchymal stromal cells (hMSC), were able to adhere to plastic, proliferate and form colonies. It was demonstrated that in some tissues (e.g. skin) MSC are the base for regeneration in adult body by giving rise to progenitor cells that can differentiate and replace damaged tissues 2, 3]. Nevertheless, some defects are too large to be regenerated only by residual hMSCs, which appear in the tissue in rather low density. Therefore, since these cells can be easily isolated from various tissues [4], it is possible to graft them back in the patient's body in the required quantity. It was also demonstrated that hMSCs possess multilineage potential and by proper treatment in vitro can be differentiated towards desired precursor and adult cells (e.g. osteoblasts). Several studies have shown that hMSCs can also be used to repair tissues that in normal conditions are not regenerated via residual hMSCs, such as kidney tissue 5]. This ability of hMSCs allows nowadays to engineer in vitro pieces of tissue that can be then implanted in order to replace defective tissue. 
Currently, several aspects are hampering broader usage of cell-based therapies for tissue regeneration, one of which is the difficulty in maintaining the survival and functionality of newly formed tissue after implantation. This is of particular importance for large tissue engineered constructs containing living cells that require a proper level of nutrients and oxygen to perform their function. Without providing robust and efficient vascularization of such constructs, cells used for their assembly will die which leads to the failure of the applied therapy. Therefore, vascularization is nowadays recognized as one of the main hurdles that have to be overcome to translate tissue engineering research to clinical applications on a broad scale $[6] 8]$.

To date, most approaches to tissue vascularization are based on stimulating the in-growth of blood vessels from the host. This strategy can be very successful when small grafts are implanted but is not good enough to satisfy the requirements of larger constructs. The main problem with vascularization of larger grafts is the time needed for the in-growing vessels to create a network that will be dense enough to cover the tissue's needs for nutrients and oxygen. For most tissues the requirement surmounts to a blood capillary every $200 \mu \mathrm{m}$ [9, 10, which obviously takes some time to grow after implantation. Studies showed that the speed of vascularization can be increased by the delivery of pro-angiogenic growth factors like VEGF or bFGF 11, 12 immobilized in the construct. Still, further improvement of this process is necessary. Lately, a lot of studies concentrate either on improving tissue regeneration strategies by introducing vascular networks in the engineered constructs prior to tissue implantation or by providing a way to guarantee fast vascularization by introducing cells that will create such a network upon transplantation. In this thesis, we describe hMSC-derived, endothelial-like cells (EL-MSC) as ideal candidate cells for building functional vascular networks prior to or upon transplantation. The necessity of connecting created networks with the host network together with the possibility of increasing the speed of host vessel in-growth is also investigated.

\subsection{Factors influencing EL-MSC applications in therapy}

\subsubsection{Differention protocol}

In chapter 3 of this thesis a protocol for endothelial differentiation of hMSCs is described. Obtaining cells that can be used to create vascular networks in engineered constructs from cells that can be isolated in large quantities circumvents problems related to the long time necessary for endothelial cell expansion. Since hMSCs can be autologous to every patient, problems with immune rejection can also be omitted. These cells are also approved to be used in the clinic when isolation and in vitro maintenance is performed according to guidelines. The presented protocol for endothelial differentiation is simple and robust; nevertheless, there are several issues that need to be addressed before using it for therapies. First of all, medium used for cell differentiation must be tested and FDA approved. Since EGM-2 is a commercially available medium with unspecified quantity of added growth factors, joined efforts between scientists and Lonza company are needed to prove that this medium is safe to be 
used for maintaining in vitro cells for in vivo applications [13]. Secondly, replacement for Matrigel induction is necessary before clinical applications are considered. Since Matrigel is a gel derived from murine sarcoma, the use of it prompts controversy, even when a growth-factor-reduced version is applied [14]. Not only is Matrigel not likely to ever be FDA approved but there is also controversy to its specific angiogenic effect, e.g. it was shown that this gel can promote adipogenesis as well [15. Our results presented in chapter 6 show, that dextran-based hydrogels are sufficient to direct hMSCs towards endothelial-like cells. Because these gels are already approved for clinical use, the possibility to introduce EL-MSCs into therapy is now real.

\subsubsection{Donor variation}

One of the challenges of clinical aplication of MSCs and other MSC-derived cells is connected with the huge variability often observed between cells obtained from different donors 16,17 . There are some applications where donor variability among MSCs was shown to have little influence on the therapeutic outcome, such as in the treatment of graft versus host disease (GVHD) 18]. The study of le Blanc et al. revealed that infusion of MSCs can be an effective therapy for patients with GVHD, irrespective of MSC donor. Nevertheless, cells applied in this study were not differentiated and therefore the therapy was likely to be less sensitive to donor variation. When the variability in response to differentiation procedures occurs [16, differentiation protocols applied on cells designated for the therapies must take this in to account and should be carefully examined for robustness and repeatability prior to application. To truly control differentiation, quality control mechanisms should be implemented. For instance, in cartilage tissue engineering, Dell'Accio et al. described a panel of markers that allow prediction of the capability of in vitro expanded adult human articular chondrocyte to generate stable cartilage in vivo [19]. Although, as shown in chapter 4, hMSCs obtained from different donors all differentiated into endothelial-like cells, quantitative differences occurred that should and most likely can be overcome after precise adjustments in culture conditions. Such adjustments require deeper insight in the differentiation mechanism combined with identification of proper markers that will allow for more personalised protocol optimization. Our research in this area, presented in chapter 4 , can be considered as a starting point towards this goal.

\subsubsection{EL-MSC introduction in vivo}

As described above, one hurdle towards clinical application of EL-MSCs is the method of delivery of the cells. In this thesis we present three ways of delivering EL-MSCs that can be considered as clinically relevant: on the surface of collagen modules (chapter 5), within dextran-based gels (chapter 6) or combined with platelet gel (chapter 7). All these strategies worked well in the animal models used, nevertheless, each of these methods should be carefully adjusted for the specific applications. An approach that will consider not only the vascularization issue but also the type of tissue that needs to be regenerated needs to be developed. Therefore, more studies are required to find the optimal carrier for every regenerative application separately. 


\subsubsection{EL-MSC application in regenerative medicine}

Another issue that should be addressed before EL-MSCs will be widely introduced in regenerative medicine is proving their value in particular applications. This topic is addressed in chapters 7, where we found out that EL-MSCs can be delivered in a bone forming construct (chapter 7 ). Further studies are required to determine the mechanism of improved bone formation before clinical trials can be performed. Also for treatment of diabetic patients more research is necessary to achieve optimal methods to transplant the islets. The implantation place that is currently used (kidney capsule) was selected, among others, based on its well-developed capillary network that was supposed to compensate for the destroyed capillaries surrounding the islets. Since EL-MSCs can improve the vascular status of the islets, this opens new possibilities with respect to selection of implantation site. Therefore, the results described in this thesis can be considered as proof of principle for application of EL-MSCs in various therapies.

\subsection{Concluding remarks and future perspectives}

The in vitro research and animal experiments described herein contribute to the broad set of clinical applications of endothelial-like cells in the field of tissue engineering. It is important to demonstrate on a large sample the additive effect of EL-MSCs on tissue regeneration. Until now, we have demonstrated that the differentiation potential of these cells is robust and donor-independent in-vitro, but not in all in vivo studies we were able to show significant improvement of new tissue formation or vascularization. Our bone study (chapter 7) was performed with a limited amount of samples and did not yield statistically significant data. Still, we were able to show an increased amount of bone in 6 out of 7 samples. Further study is necessary to confirm this phenomenon. At the moment of writing, an in vivo experiment investigating the effect of EL-MSCs on islets of Langerhans functionality is running. No matter which application is chosen, from a translational point of view, pre-clinical studies of constructs containing ELMSCs need to be carried out in large immunocompetent animal models, and long-term outcomes should be followed up. This is necessary to finally prove that such therapies will be safe for patients. For such experiments, development of an immunologically humanized animal is crucial. Additional research is also required that will allow to determine the fate of implanted EL-MSCs. Although our in vitro experiments (chapter 5) demonstrated that EL-MSCs did not undergo dedifferentiation, it is still necessary to find out what exactly is happening with these cells in vivo.

In our studies we did not compare the use of EL-MSCs for vascularization purposes with other clinically relevant cells like endothelial progenitor cells (EPC). Such study might reveal complimentary results of EL-MSC and EPC application and, likely, open a possibility of combining these cell types for better vascularization. A similar possibility lies in the combination of EL-MSCs and pro-angiogenic growth factors in the engineered construct. In chapter 6 we show that VEGF incorporation has a beneficial effect on the sprouting of MSCs and EL-MSCs within dextran-based hydrogel. Nev- 
ertheless, further research is necessary to determine the optimal combination, way of introduction and amount of applied growth factors.

The influence of EL-MSCs on tissue engineered constructs should also be examined from one more angle. Although our study did not show any negative impact of EL-MSCs on other cell types within constructs (e.g. the bone forming capacity of hMSCs was not affected), there is always the possibility that EL-MSCs will disturb the expected performance of other cells. An example of such risk was demonstrated in chapter 5 of this thesis. MSC addition to collagen-based modular constructs had longterm negative effect on the vascularization of these constructs. Therefore, all possible interactions between various cell types need to be carefully examined before application and in case any undesirable influence is discovered, alternative protocols, e.g. separation of various cell types in the construct, both special and temporal, should be considered.

Next, the work described in this thesis is restricted to one strategy of vascularization, that is by introducing cells which are able to organize themselves and create a vascular network within the construct. This approach still requires in-growth of host blood vessels at least in the outer region of the implant. The in-growing vessels need to connect to the engineered vessel network. In case of large implants this process might still be too slow. The solution to that problem could be the introduction, within the construct, of engineered vessels that are large enough (microvessels) to be surgically anastomosed with host blood vessels. Future research should therefore be focused on a bi-directional approach that will provide both capillaries and microvessels within tissue engineered graft.

Finally, we have tested EL-MSCs only as cell source for construct vascularization. Still, endothelial-like cells derived from MSCs are likely to be useful in other applications that up to now required endothelial cells. Both MSCs and EL-MSCs in prolonged in vitro expansion create cell sheets that are strong and easily detachable even when cultured on standard tissue culture plastic. It will be very interesting to check, whether EL-MSCs can replace endothelial cells in cell-sheet-based large vessel engineering, as described by L'Heureux et al. [20]. Thus, the full potential of EL-MSCs in various applications remains yet to be explored. 


\subsection{Bibliography}

[1] A. J. Friedenstein, R. K. Chailakhjan, and K. S. Lalykina. The development of fibroblast colonies in monolayer cultures of guinea-pig bone marrow and spleen cells. Cell Tissue Kinet, 3(4):393-403, 1970.

[2] E. Mansilla, G. H. Marin, H. Drago, F. Sturla, E. Salas, C. Gardiner, S. Bossi, R. Lamonega, A. Guzmán, A. Nuñez, M. A. Gil, G. Piccinelli, R. Ibar, and C. Soratti. Bloodstream cells phenotypically identical to human mesenchymal bone marrow stem cells circulate in large amounts under the influence of acute large skin damage: New evidence for their use in regenerative medicine. Transplant Proc, 38(3):967-969, 2006.

[3] Mikako Sasaki, Riichiro Abe, Yasuyuki Fujita, Satomi Ando, Daisuke Inokuma, and Hiroshi Shimizu. Mesenchymal stem cells are recruited into wounded skin and contribute to wound repair by transdifferentiation into multiple skin cell type. The Journal of Immunology, 180(4):2581-2587, 2008.

[4] R. A. Musina, E. S. Bekchanova, and G. T. Sukhikh. Comparison of mesenchymal stem cells obtained from different human tissues. Bull Exp Biol Med, 139(4):504$9,2005$.

[5] M. B. Herrera, B. Bussolati, S. Bruno, V. Fonsato, G. M. Romanazzi, and G. Camussi. Mesenchymal stem cells contribute to the renal repair of acute tubular epithelial injury. Int J Mol Med, 14(6):1035-41, 2004.

[6] L. G. Griffith and M. A. Swartz. Capturing complex 3d tissue physiology in vitro. Nat Rev Mol Cell Biol, 7(3):211-24, 2006.

[7] R. Langer. Tissue engineering: perspectives, challenges, and future directions. Tissue Eng, 13(1):1-2, 2007.

[8] M. W. Laschke, Y. Harder, M. Amon, I. Martin, J. Farhadi, A. Ring, N. TorioPadron, R. Schramm, M. Rucker, D. Junker, J. M. Haufel, C. Carvalho, M. Heberer, G. Germann, B. Vollmar, and M. D. Menger. Angiogenesis in tissue engineering: breathing life into constructed tissue substitutes. Tissue Eng, 12(8):2093-104, 2006.

[9] C. K. Colton. Implantable biohybrid artificial organs. Cell Transplant, 4(4):41536, 1995.

[10] A. Zumstein, O. Mathieu, H. Howald, and H. Hoppeler. Morphometric analysis of the capillary supply in skeletal muscles of trained and untrained subjects-its limitations in muscle biopsies. Pflugers Arch, 397(4):277-83, 1983.

[11] Darnell Kaigler, Zhuo Wang, Kim Horger, David J. Mooney, and Paul H. Krebsbach. Vegf scaffolds enhance angiogenesis and bone regeneration in irradiated osseous defects. Journal of Bone and Mineral Research, 21(5):735-744, 2006. 
[12] Anat Perets, Yaacov Baruch, Felix Weisbuch, Gideon Shoshany, Gera Neufeld, and Smadar Cohen. Enhancing the vascularization of three-dimensional porous alginate scaffolds by incorporating controlled release basic fibroblast growth factor microspheres. Journal of Biomedical Materials Research Part A, 65A(4):489497, 2003.

[13] Christopher J. Centeno and Stephen B.A. Faulkner. The use of mesenchymal stem cells in orthopedics: Review of the literature, current research, and regulatory landscape. Journal of American Physicians and Surgeons, 16(2):38-44, 2011.

[14] E. Polykandriotis, A. Arkudas, R. E. Horch, and U. Kneser. To matrigel or not to matrigel. Am J Pathol, 172(5):1441; author reply 1441-2, 2008.

[15] J. A. Rophael, R. O. Craft, J. A. Palmer, A. J. Hussey, G. P. Thomas, W. A. Morrison, A. J. Penington, and G. M. Mitchell. Angiogenic growth factor synergism in a murine tissue engineering model of angiogenesis and adipogenesis. $\mathrm{Am}$ J Pathol, 171(6):2048-57, 2007.

[16] R. Siddappa, R. Licht, C. van Blitterswijk, and J. de Boer. Donor variation and loss of multipotency during in vitro expansion of human mesenchymal stem cells for bone tissue engineering. J Orthop Res, 25(8):1029-41, 2007.

[17] D. G. Phinney, G. Kopen, W. Righter, S. Webster, N. Tremain, and D. J. Prockop. Donor variation in the growth properties and osteogenic potential of human marrow stromal cells. J Cell Biochem, 75(3):424-36, 1999.

[18] K. Le Blanc, F. Frassoni, L. Ball, F. Locatelli, H. Roelofs, I. Lewis, E. Lanino, B. Sundberg, M. E. Bernardo, M. Remberger, G. Dini, R. M. Egeler, A. Bacigalupo, W. Fibbe, O. Ringden, Blood Developmental Committee of the European Group for, and Transplantation Marrow. Mesenchymal stem cells for treatment of steroid-resistant, severe, acute graft-versus-host disease: a phase ii study. Lancet, 371(9624):1579-86, 2008.

[19] Francesco Dell'Accio, Bari Cosimo De, and Frank P. Luyten. Molecular markers predictive of the capacity of expanded human articular chondrocytes to form stable cartilage in vivo. Arthritis \&3 Rheumatism, 44(7):1608-1619, 2001.

[20] N. L'Heureux, S. Paquet, R. Labbe, L. Germain, and F. A. Auger. A completely biological tissue-engineered human blood vessel. FASEB J, 12(1):47-56, 1998. 



\section{List of Publications}

Hugo Fernandes, Koen Dechering, Eugene Van Someren, Ilse Steeghs, Marion Apotheker, Anouk Leusink, Ruud Bank, Karolina Janeczek, Clemens Van Blitterswijk, and Jan de Boer (2009) The role of collagen crosslinking in differentiation of human mesenchymal stem cells and MC3T3-E1 cells. Tissue Eng Part A 15: 3857-3867

Karolina Janeczek Portalska, Anne Leferink, Nathalie Groen, Hugo Fernandes, Lorenzo Moroni, Clemens van Blitterswijk and Jan de Boer. (2012) Endothelial differentiation of mesenchymal stromal cells. PLoS One 7: e46842.

Karolina Janeczek Portalska, Nathalie Groen, Guido Krenning, Nicole Georgi, Anouk Mentink, Martin C. Harmsen, Clemens van Blitterswijk and Jan de Boer (2013) The Effect of Donor Variation and Senescence on Endothelial Differentiation of Human Mesenchymal Stromal Cells. Tissue Eng Part A.

Karolina Janeczek Portalska, M. Dean Chamberlain, Chuen Lo, Clemens van Blitterswijk , Michael V Sefton and Jan de Boer (2013) Collagen modules for in situ delivery of mesenchymal stromal cell-derived endothelial cells for improved angiogenesis. J Tissue Eng Regen Med.

Karolina Janeczek Portalska ${ }^{\star}$ Liliana Moreira Teixeira®, Jeroen C. H. Leijten, Rong Jin, Clemens van Blitterswijk, Jan de Boer and Marcel Karperien (2013) Boosting angiogenesis and functional vascularization in injectable dextran-hyaluronic acid hydrogels by endothelial-like mesenchymal stromal cells. Tissue Eng Part A.

Karolina Janeczek Portalska, Hugo Fernandes, Daniel Saris, Clemens van Blitterswijk, Jan de Boer. Tissue engineering of blood vessel: from large vessels towards capillaries. Submitted

${ }^{\star}$ shared first co-authorship 
Karolina Janeczek Portalska, Eelco Fennema, Henk Garritsen, Auke Renard, Clemens van Blitterswijk, Jan de Boer. Human mesenchymal stromal cells as single cell source for both bone and vessel engineering. Submitted

Karolina Janeczek Portalska ${ }^{\star}$ Mijke Buitinga^, Janneke Hilderink, Eelco de Koning, Marten Engelse, Clemens van Blitterswijk, Marcel Karperien, Aart van Apeldoorn, Jan de Boer. Endothelial-like mesenchymal stromal cells to promote islets revascularization. In preparation

\footnotetext{
${ }^{\star}$ shared first co-authorship
} 


\section{Curriculum Vitae}

Karolina Janeczek Portalska was born on the 23rd of February 1984 in Kraków, Poland. In October 2003 she started her study of Biotechnology at the Jagiellonian University, Kraków, Poland. During her study she performed several traineeships, including a summer assignment in the Laboratory for Stem Cell Research, Aalborg University, Denmark, an Erasmus project in the Institute for Human Genetics, George August University, Goetingen, Germany and a master assignment in the Group of Tissue Regeneration at the University of Twente, Enschede, the Netherlands. In June 2003 she graduated and obtained her Master of Science in Medical Biotechnology degree. Her master project was performed under the supervision of Dr. Justyna Drukała and Prof. Dr. Jan de Boer and her master thesis was entitled "Relation Between Human Mesenchymal Stem Cells Differentiation, Cell Shape and Focal Adhesion Assembly". In July 2008 she started her PhD at the department of Tissue Regeneration, MIRA Institute for Biomedical Technology and Technical Medicine at the University of Twente under the supervision of Prof. Dr. Jan de Boer. For part of the work described in this thesis Karolina received a research grant to be used for working abroad as guest researcher in the Donnelly Centre for Cellular and Biomolecular Research, Toronto, Canada. This project was performed in close collaboration with Prof. Dr. Michael Sefton and Dr. Dean Chamberlain. During the past 5 years Karolina explored the potential of mesenchymal stromal cells for vessel engineering, the results of which are described in this thesis. 



\section{Acknowledgements}

$\mathrm{A} \mathrm{PhD} \mathrm{thesis} \mathrm{is} \mathrm{never} \mathrm{a} \mathrm{result} \mathrm{of} \mathrm{merely} \mathrm{the} \mathrm{work} \mathrm{of} \mathrm{one} \mathrm{person,} \mathrm{there} \mathrm{are} \mathrm{always}$ many contributors. Therefore I would like to thank you all who helped me to prepare this dissertation, both with your scientific input as well as support and friendship.

First of all, Jan, you have been a great supervisor to. I appreciate all your scientific guidance, help and support. Without you this thesis would not have been possible. I am grateful for you encouraging me to test on my own all the crazy ideas I had and for you always offering me the freedom to explore new research topics.

It is also a great pleasure to acknowledge my second promotor, Clemens van Blitterswijk, for giving me the opportunity to perform my master assignment and then for inviting me to conduct my $\mathrm{PhD}$ research in the Tissue Regeneration group.

Marcel, I want to thank you for allowing me to involve you and four of your $\mathrm{PhD}$ students, Nicole, Liliana, Jeroen and Mijke in my research. I highly appreciate the collaboration and discussions that we had. Without your contribution this thesis would not have been the same. Working with you all was a great experience that encouraged me to take eagerly every possibility of new collaboration. Marco and Guido, I am really grateful for your invitation to Groningen, sharing your experience about endothelial cells and for helping me with my first in vivo experiment. I have learned a lot from you two. Michael, Dean, Chuen, the time I spent in Toronto was short but fruitful. I greatly enjoyed working with you, seeing the Niagara Falls, drinking the ice wine and eating Chinese food.

I also owe special thanks to Dr. Jacqueline Alblas, Dr. Bob Geelkerken, Prof. Marco Harmsen, Dr. Lorenzo Moroni and Prof. Anton-Jan van Zonneveld for being part of my graduation committee. I highly appreciate the time you took to discuss my work.

I really enjoyed my $\mathrm{PhD}$ life in Enschede. Hugo, thank you for being my first supervisor. You, Andre and Ram were my first office mates. The way you talked to each other and argued about the coffee was making my days, you were the ones showing me the craziness and friendliness of the whole TR group. Ana, Aliz, Anindita, Joyce and Sanne, thank you being my first companions. Anouk, you were always ready to help whenever anybody needed it. I am really grateful for all your support. Sandra, 
I joined your office when I started my PhD. I will always remember the chocolate and cookies we shared, all the gossips I learned from you and your friendship. I enjoyed all the parties you and Juan invited me to and of course your great wedding. Nicole and Ellie, you were the ones that managed to share the office with me for longest. Thank you for not running away screaming, for high tolerance to the smell of isopropanol and for being my friends despite all the fuss I made. Ellie, special thanks for not getting offended for life after I did not recognize you during our first conference together. Chris, despite all your love for Gobi you always understood my need to stay 1 meter away from him, thank you for that. Lili and Jeroen, working with you was a great experience. I really enjoyed your flexible planning, sarcastic humour and inclination to offend people (this is mainly about one of you, guess which...); your scientific enthusiasm was really infectious. Anne, thank you for the scaffolds and for being my final office mate. Nathalie, you have been the best Master student I could have dream of. Bach, I will always remember our quest for mice, the trip to Utrecht, your help with implantation and our collaboration in winning iPods. Mijke and Janneke, thank you for hunting islets with me (Mijke, if you don't publish our work soon you know what I will do). Audrey, you are the second craziest person in the whole TR, please never change. Bernke, thank you for bringing all the colours to the university corridors. Charlene and Alex, you have added the French accent to our life in Enschede. And last but not least: to all the TR / DBE members - thank you for your support in the lab, for all the small talks we had and for adding to the great working atmosphere.

Tomek, Kinga, zwiedziliśmy razem kawał świata. Marta, Ania, Klaudia, Magda, zawsze cieszyłam się na Wasze odwiedziny.

Kochani rodzice: dziękuję, że akceptowaliście moje wybory, wspieraliście mnie i pomagaliście kiedy tego potrzebowałam. Basia, Berenika, jesteście najlepszymi siostrami na świecie (tylko trochę zwariowanymi).

Maciek, sam wiesz najlepiej ile dla mnie znaczysz. Bez Ciebie nie napisałabym tej pracy. Dziękuje za wspaniałą redaktorska pracę, za wparcie techniczne, graficzne i stylistyczne. Cieszę się, że razem z Tomkiem jesteście ze mną. Kocham Was. 